\title{
NEW STRUCTURAL POLICY IN AN OPEN MARKET ECONOMY
}





\title{
NEW STRUCTURAL POLICY IN AN OPEN MARKET ECONOMY
}

\author{
Edited by: \\ Justin Yifu Lin and Alojzy Z. Nowak
}

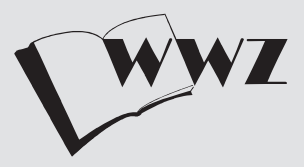

University of Warsaw

Faculty of Management Press

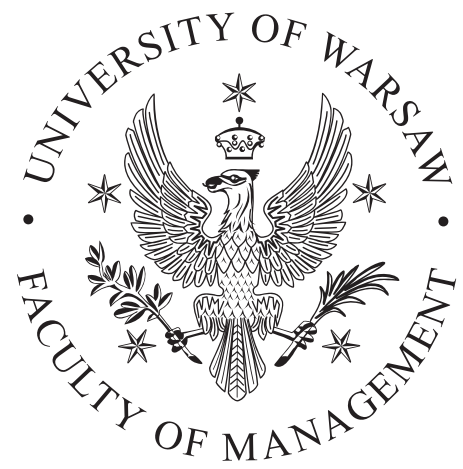


Reviewer: Professor Zofia Wysokińska, PhD, University of Łódź, Poland

Editorial Supervisor: Jerzy Jagodziński

Cover design: Agnieszka Miłaszewicz

Translations: Grzegorz Grątkowski, Redacto Knit Agnieszka Zerka-Rosik

"Publication co-financed from subsidies for maintaining research potential at the Faculty of Management at the University of Warsaw”.

The Polish version of the book is available on the website:

http:/www.wz.uw.edu.pl/portale/wydawnictwo-WZUW/wydawnictwo/

produkt/30319/nowa-polityka-strukturalna-w-warunkach-otwartej-gospodarkirynkowej

(C) Copyright by Wydawnictwo Naukowe Wydziału Zarządzania

Uniwersytetu Warszawskiego, Warszawa 2018

ISBN: 978-83-65402-91-2

ISBN (on line): 978-83-65402-92-9

https://doi.org/10.7172/978-83-65402-92-9.2018.wwz.10

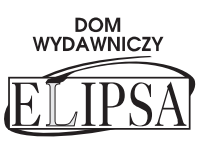

Opracowanie komputerowe, druk i oprawa:

Dom Wydawniczy ELIPSA

ul. Inflancka 15/198, 00-189 Warszawa

tel. 226350301

e-mail: elipsa@elipsa.pl,www.elipsa.pl 


\section{Contents}

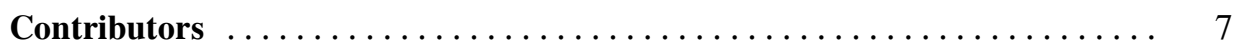

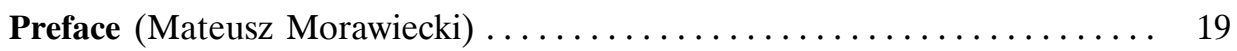

Introduction $\ldots \ldots \ldots \ldots \ldots \ldots \ldots \ldots \ldots \ldots \ldots \ldots \ldots \ldots \ldots \ldots \ldots \ldots \ldots \ldots \ldots, 21$

\section{PART ONE}

\section{Alojzy Z. Nowak}

What is the Future of the Global Economy? .................. 31

Kenneth Friedman, Ruth Taplin

Free Trade or Unfettered National/Corporate Interest? ............. 43

Harald Sander

A European Policy Agenda in and for the New Global Economy ........ 56

Andrzej Sopoćko

Secular Structural Processes. Unexpected Results ............... 88

Kazimierz Ryć

Control of Capital Against the Middle Income Trap

\section{PART TWO}

\section{Justin Yifu Lin, Xiaobing Wang}

The Facilitating State and Economic Development: The Role of the State in New Structural Economics ............................ 123

\section{Grzegorz Jędrzejczak, Henryk Sterniczuk}

The Use of the New Structural Economics for Modernization and Increasing the Innovativeness of the Polish Economy ........... 142

\section{Marian Górski, Patrycja Chodnicka-Jaworska}

The Process of Catching up with the Economic Development of OECD Countries and the Role of Foreign Direct Investment in this Process 


\section{Beata Kozlowska-Chyła}

Legal Environment for Foreign Investments in Poland ............ 187 Michał Kurtyka

Can States Be Turned into Automotive Innovation Hubs? . . . . . . . . . . 198

Bogdan J. Góralczyk

Poland on the Route of the Chinese Silk Road: A Chance

for Development or Just a Challenge? . . . . . . . . . . . . . . . . . . . . 213 


\section{Contributors}

Patrycja Chodnicka-Jaworska - PhD in Economics, assistant professor at the Faculty of Management, University of Warsaw, in the Chair of Banking and Monetary Markets, author and co-author of over 100 scholar publications in Polish and English. Participant of conferences and seminars, both academic and field-specific (including those held by STERN, University of Oxford, University of Cambridge, London School of Economics). She has been involved in academic research in the area of banking risk management and has been member of a research team operating under the project "Regulatory determinants of pro-cyclicity in banks' crediting activities" and carrying out studies funded by decision of the Director of the National Science Centre. She has also been heading several research projects, i.a concerning determinants of credit ratings made by financial institutions and states, the influence of changes in credit ratings upon the financial market operation, efficiency of the banking sector, and the risk of the banking sector bankruptcy. She has been member of foreign science committees, editorial teams of expert magazines and conferences; co-editor of a scholar magazine the Faculty of Management Working Paper Series. Member of ABSRC, IRMC, EAEPE. She has been distinguished with several awards and prizes, including a fellowship of the Minister of Science and Higher Education for outstanding achievements and merits for doctoral students (2012/2013); also awarded by the Congresses of Capital Market and the Competition of the 16th Scholar Conference of Young Economists.

Kenneth Friedman - Professor at Regis University, Colorado, USA where he has been awarded for excellence in teaching. He is also the president of Clifton Mining, a micro-cap publicly-traded company involved in precious metals exploration and now receiving production royalties, and also in biotech, with a private corporation it founded producing the only patented and FDAcleared nano-particle silver anti-pathogenic.

$\mathrm{He}$ is the author of two books, Predictive Simplicity: Induction Exhum'd (Pergamon) and Myths of the Free Market (Agora), has published articles in physics journals and philosophy journals, and is the book review editor of Interdisciplinary Journal of Economics and Business Law. He received his 
Ph.D. (philosophy) from M.I.T., an S.M. (physics) from M.I.T. and a M.A. (philosophy) from Harvard University.

A recipient of an American Council of Learned Societies fellowship, he spent a year studying under Ilya Prigogine at the Free University of Brussels. He has been influenced by considerations of non-linearity.

Bogdan Góralczyk - Professor in the Centre for Europe, University of Warsaw; expert in political science and sinologist. Former head of the Political Cabinet of the Minister of Foreign Affairs (2001-2003) and a diplomat for many years; in the years 2003-2008 Ambassador of the Republic of Poland in Thailand, Philippines and the Union of Myanmar (formerly Burma). Since 1 September 2016 Director of the Centre for Europe at the University of Warsaw. Regular commentator of TVN24 channel Biznes $i$ Świat (Business and the World) and of the Institute for Citizenship; frequent guest of TOK FM radio. Publishes, e.g., in the portal of the National Bank of Poland "Obserwator Finansowy" and at wp.pl. Author of many books and articles about China and Asia, global problems and about Hungary, such as: Zmierzch i brzask. Notes z Bangkoku (Dusk and Dawn. Notes from Bangkok), Toruń 2009/2010; Chiński Feniks. Paradoksy wschodzacego mocarstwa (Chinese Phoenix. Paradoxes of the Rising Power), Warsaw 2010; Zlota Ziemia roni tzy. Esej birmański (Golden Land Sheds Tears. An Essay in Burma), Warsaw 2011; Przebudzenie smoka. Powrót Chin na scenę globalna (The Dragon Awakens. China's Return to the Global Scene), Warsaw 2012; Sun Yat-sen. Misjonarz rewolucji (Sun Yat-sen. The Revolution Missionary), Warsaw 2013. Editor and co-author of the following volumes: Polska-Chiny. Wczoraj, dziś, jutro (Poland-China. Yesterday, Today, Tomorrow), Toruń 2010 (English version 2014); Unia Europejska jako aktor na scenie globalnej. Razem czy osobno? (European Union as an Actor in the Global Scene. Together or Apart?), Warsaw 2014 (extended English version under preparation) and European Union in the Global Scene: United or Irrelevant?, Warsaw 2015.

Lectures in Poland and abroad. Specialises in global and Asian issues (China, Burma-Myanmar, Thailand and Philippines), although his scope of interest also includes issues concerning the Diplomatic Protocol and cultural differences (naturally stemming from many years of his diplomatic experience and long periods spent abroad).

Marian Górski - Professor of Economics; head of the Faculty of Financial Systems and of the Academic Unit for Banking and Financial Markets in the Faculty of Management, University of Warsaw. Specialised in finance, banking, macroeconomics, monetary policy. Author and co-author of many monographs 
and scholar articles. His academic manual entitled System Finansowy Gospodarki (Financial System in the Economy) had three editions so far (2007; 2009; 2013). In the years 1990-1996 the Dean in the Faculty of Management, University of Warsaw, University of Warsaw. At present, member of the Senate of the University of Warsaw, president of the Senate Committee for budget and finance.

He has been, both in the past and at present, involved in the economic practice. In the years 1991-2005 member and president of supervisory board one of Poland's larger banks - BZWBK S.A. As partner in the consulting company Premium-econ in the years 1991-2003 he was advising to the Minister of the State Treasury and the Minister of Economy, among others. At present member of the Council for WIBID and WIBOR reference rates which supervises the market of inter-bank deposits in Poland.

Grzegorz Jędrzejczak - Professor in the University of Warsaw, $\mathrm{PhD}$ in Economics. In the years 1989-1991 Undersecretary of State in the Ministry of Ownership Transformations responsible for creation of Polish capital market. In the years 1993-2013 employed in the World Bank in Washington, DC, in the Department of Private Sector Development and the Financial System of Europe and Central Asia and representative of the World Bank in Ukraine and Azerbaijan. Member of the Supervisory Board of Polish Foundation for Management Research and IBD Business School.

Since 1980s successfully combines scholar interests with practical activities. Areas of his interests include: privatisation, creation of regulated capital markets, emergence of corporate culture in Poland and other countries under transformation from centrally-planned to market economy. Important fields of his practical and analytical activities include development programmes in developing countries and the potential for support from international organisations, with particular emphasis upon the World Bank. At present specialised in issues concerning conditions for the economic policy which promotes innovativeness in middle income countries and analyses of long-term opportunities and threats to Polish economy.

Beata Kozłowska-Chyła - Doctor with post-doctoral degree in legal science; associate professor in the Faculty of Law and Administration, University of Warsaw in the Institute of Civil Law, the Unit of Commercial Law; lecturer in the Faculty of Economic Sciences, University of Warsaw. Solicitor specialised in commercial affairs. Member of managing and supervisory boards in large joint stock companies, including companies with the State Treasury shareholding. 
Arbitrator recommended in the Court of Arbitration at the National Chamber of Commerce in Warsaw.

Author of many scholar publications in the fields of company law, securities law, issues of ownership transformations, privatisation of enterprises, and insurance law, e.g. Reprezentacja spółki kapitałowej w organizacji (Representation of Corporations in an Organisation), Warsaw 2015; Komentarz do Ustawy o działalności ubezpieczeniowej i reasekuracyjnej (Commentary to the Insurance and Reinsurance Activities Act) (co-author), Warsaw 2017, Nowe regulacje zasad zarządzania mieniem państwowym w zakresie powoływania i odwoływania członków organów nadzorczego i zarządzającego w spółkach z udziałem Skarbu Państwa, (New Regulations Concerning the Principles of Management of the State Property in the Area of Appointment and Dismissal of Members of Supervisory and Managing Bodies in Companies with the State Treasury Shareholding), PUG 2/2017; Wyzwania globalizacji dla rynku ubezpieczeń (Challenges of Globalisation to the Insurance Market) (co-author), Warsaw 2016; Postępowanie administracyjne w sprawie zezwolenia na wykonywanie działalności ubezpieczeniowej i reasekuracyjnej - wybrane aspekty (Administrative Proceeding on the Approval for Performance of Insurance and Reinsurance Activities - Selected Aspects) (co-author), Wiadomości Ubezpieczeniowe 2/2016; Jurydyczna koncepcja podmiotowości spółki partnerskiej a status prawny jej zarządu (Juridical Concept of Legal Personality of a Partnership and the Legal Status of its Management), Forum Prawnicze 2/2015; Zdolność prawna handlowych spółek osobowych na przykładzie spółki partnerskiej, (Legal capability of private companies based on a partner company) Forum Prawnicze 3/2015; Nieformalny zarząd spółki partnerskiej (Informal Board of Management in a Partnership), PUG 5/2015; Tryb wyłaniania zarządu w spółkach zależnych od spółek Skarbu Państwa (The Procedure of Appointing the Board of Management in Companies Subsidiary to Companies of the State Treasury), Wrocław 2015; Pełnomocnik w obrocie wekslowym - uwagi na tle art. 8 Prawa wekslowego (A Proxy in Bills of Exchange Trade), PUG 9/2015; Status prawny zawieszonego członka zarządu spółki akcyjnej oraz wpływ zawieszenia na strukturę organizacyjną zarządu (Legal Status of a Suspended Member of the Board of Management of a Joint-Stock Company and the Impact of Suspension Upon Changes in the Board of Management Organisational Structure), PPH 5/2015; Tryb zawieszania w czynnościach członka zarządu spółki akcyjnej oraz przywrócenia do pełnienia funkcji (The Procedure of Suspension of a Member of the Board of Management of a Joint-Stock Company in Performance of his/her Duties and the Restitution), PPH 6/2015; Delegowanie członka rady nadzorczej do wykonania pojedynczej czynności członka zarządu (Delegation of a Member of the 
Supervisory Board to Performance of a Single Action as Member of the Board of Management), Glosa 2/2015.

Michał Kurtyka - graduate of prestigious Ecole Polytechnique in Paris where he obtained the degree of engineer in 1996. Scholar in the field of quantum optics in the National Institute of Standards and Technologies near Washington (DC) where he worked under tutorship of the Nobel Prize winner in physics, William D. Phillips (who was also the promoter of Kurtyka's dissertation concerning the conditions for the formation of Bose-Einstein condensate. During his studies he was also specialised in economy, with particular emphasis upon market organisation - studies under tutorship of Professor Jean Tirole, Nobel Prize winner in economy (2014). In the area of international economy he studied in Louvain La Neuve University and obtained the master degree in Warsaw School of Economics.

Employed in the Office of the Committee for European Integration where he headed an analytical team supporting the process of negotiation on the accession to the European Union in the team of the Chief Negotiator Jan Kułakowski; directly involved in the area of transport and energy. As an advisor he co-managed projects of modernisation of Poland's largest companies and supported their adaptation to challenges of the European market. Promoter of European cooperation in the area of industrial transformation and adaptation of European industry to challenges of globalisation, including with European Labour University and the Dublin Foundation.

He made his doctoral defence in the University of Warsaw. Lecturer in the management of change, economy, market organisation and industrial strategy in the University of Warsaw, Collegium Civitas, Oxford Programme On Modern Poland. Co-author of the concept or implementing effective changes in an enterprise, described in the book Zarzqdzanie zmianq. Od strategii do dziatania (Managing the Change: From Strategy to Action); author of the book Od restrukturyzacji do modernizacji. Opóźniona transformacja polskiego sektora elektroenergetycznego in the years 1990-2009 (From Restructuring to Modernisation. Delayed Transformation of Polish Electric Power Sector in the Years 1990-2009). Author of the governmental programme for development of electromobility in Poland, described for the first time as concept in the book he co-wrote with Professor Leszek Jesien, New Electricity and New Cars 1990-2009”.

From 1 January 2016 Undersecretary and then Secretary of State in the Ministry of Energy, where he was directly responsible for technological development and the launch of innovation in the energy sector, implementation of climate and energy policy in fuels and gas sector, international relations with states 
and international organizations. His duties also included supervision over Poland's largest State Treasury companies, including Orlen, Lotos and PGNiG. Initiator of the "Electromobility Development Plan". Supervised preparation of the Electromobility and Alternative Fuels Act as well as the Low-Emission Transport Act. Entrusted with the office of the President of the Electromobility Program Steering Committee.

On 27 April 2018 appointed to the office of the Assignee for COP 24 Presidency. At present Secretary of State in the Ministry of Environment.

Justin Yifu Lin - Professor and honourable Dean of National School of Development at the University of Beijing. In 1986 obtained the doctoral degree in economy in the University of Chicago and in 1987 returned to China. For fifteen years performed the function of director-founder of the Chinese Centre for Economy in the University of Beijing where also worked as Professor. In the years 2008-2012 he held the office of the chief economist and Vice-President of the World Bank being the first economist from any developing country to hold this office.

Foreign member of the British Academy, member of the Academy of Sciences for the Developing World; doctor honoris causa of the Université d'Auvergne. Author of twenty five books, including Economic Development and Transition: Thought, Strategy and Viability (2009); Demystifying the Chinese Economy (2011); New Structural Economics: A Framework for Rethinking Development and Policy (2012); The Quest for Prosperity: How Developing Countries Can Take Off (2012); Against the Consensus. Reflections on the Great Recession (2013).

His stimulating works inspire scholars, students, decision-makers and anybody interested in the global economy.

Alojzy Zbigniew Nowak - Professor of Economics; graduate of: SGPiS (at present, Warsaw School of Economics); in the field of economics- University of Illinois at Urbana-Champaign, USA; in the field of banking, finance and capital markets - University of Exeter, United Kingdom; in the field of economics in the Free University of Berlin, Germany and International Economics at the University of Antwerp (RUCA), Belgium.

In 1991 awarded the Rector Prize in the University of Warsaw for his doctoral dissertation; in 1996 awarded the Prize of the Minister of National Education for his book entitled Banki a gospodarstwa domowe - dynamika rozwoju (Banks and Households - Dynamics of Growth).

At present the Dean of the Faculty of Management, University of Warsaw. In the years 2012-2016 Vice-Rector for Research and International Relations in 
the University of Warsaw. Visiting Professor in over a dozen universities all over the world; has been lecturing in France, United Kingdom (incl. the University of Cambridge), USA, Russia, China and Korea. Entrusted, both in the past and at present, with a number o advisory functions. Member of several supervisory boards.

Professor A.Z. Nowak is distinguished by his involvement in public activity. He has been member of the Committee assigning "Teraz Polska" Polish Promotional Emblem, of the National Development Council at the President of the Republic of Poland, the President of Polish University Sports Association (AZS) and the President of AZS at the University of Warsaw. Regular member or contributor to many scholar and scientific organizations and program councils of magazines (incl. international). Author of many scholar publications in Polish, English, German and Russian.

Kazimierz Ryć - Professor of Economics, employed in the Faculty of Management, University of Warsaw. Started his academic career as an assistant in the Faculty of Political Economy, headed by the prominent Polish economist Professor Oskar Lange; his doctoral dissertation was prepared under Professor Włodzimierz Brus. In 1970s has three academic placements in France, in La Sorbonne. Co-author of the implemented concept of popular car industry in Poland. Co-founder of the Faculty of Management, University of Warsaw - Poland's oldest and Central and Eastern Europe's first faculty of business. Expert in the Commission for the Economic Reform; head of the Unit for Market Economy.

Vice-Dean and Dean in the Faculty of Management, University of Warsaw for many terms of office. At present lectures in macroeconomics, macroeconomic and sector-specific policy, and social policy. Tutors the procedures for doctoral degrees, involves in scholar research in two areas: macroeconomics and health care sector. Author of many publications in the field of changing consumption structure dynamics, industrial policy and problems of macroeconomic policy under conditions of supra-national integration and globalisation.

Harald Sander - Professor of economics and international economics at Technische Hochschule (TH) Köln, where he also has been awarded the Jean Monnet Chair "Europe in the Global Economy". Director of the Institute of Global Business and Society at TH Köln and co-founder of the GlobalMBA program, a joint graduate program of TH Köln with the University of Warsaw and the University of North Florida. Holds also a position as professor of economics at Maastricht School of Management. Author of numerous articles 
in leading journals, such as Journal of International Money and Finance, Journal of Banking and Finance, Journal of Financial Stability, Applied Economics, Economic Letters, Economic Systems, Comparative Economic Studies, Quarterly Review of Economics and Finance, South African Journal of Economics, Credit and Capital Markets, and Journal of International Financial Markets, Institutions and Money. (Co-) author of books on Integrating Europe's Retail Banking Markets: Where Do We Stand? (2007), Consumer Credit in the Eurozone: Evidence on the Emergence of a Single Eurozone Retail Banking Market (2002), and Kapitalbildung, Finanzmärkte und Beschäftigung. Eine vergleichende Studie makroökonomischer Analysekonzepte (1986). Co-editor of books on World Trade after the Uruguay Round. Prospects and Policy Options for the 21st Century (1996) and Economic and Corporate Restructuring. Experiences and Challenges of the Decade (1996). Contributor to scholarly handbooks such as Handbook of Competition in Banking and Finance (2017), Handbook of Environmental and Sustainable Finance (2016), and The Encyclopedia of Central Banking (2015). Associate Editor of Finance Research Letters and member of the editorial advisory boards of Journal of Banking and Financial Economics, Foundations of Management, and the Yearbook of Polish European Studies. Visiting Researcher at the Research Department of the International Monetary Fund (1986-7, 1989), Contemporary Europe Research Centre at the University of Melbourne (2002), Global Business Institute at New York University (2006), and extramural research fellow at Graduate School of Business and Economics at Maastricht University (2003-). Grantee of the European Union, Deutsche Forschungsgemeinschaft, State government of North-Rhine Westphalia, Centre for European Policy Studies, European Credit Research Institute, and Goethe Institute.

Contact: TH Köln, Claudiusstr. 1, 50678 Koeln, Germany. Email: harald. sander@th-koeln.de

Andrzej Sopoćko - Professor of Economics since 1994 (the title awarded by the President of the Republic Poland); employed in the Faculty of Management, University of Warsaw and in the Polish Academy of Science. One of authors of Polish systemic transformation of early 1990s; crucial in the process of preparation of the anti-monopoly Act and the establishment of the Office for Competition and Consumer Protection. The President of the OCCP in the years 1995-1997. Played an important role in the creation of the Warsaw Stock Exchange (initially as Member of Board, then, in the years 2003-2006, as VicePresident). Main economic advisor to the Prime Minister, Vice-Minister of Finance (in the years 2001-2003). 
Author of many publications (c. 150, including 8 books). Many foreign stays and placements - three times in West Germany, three times in the USA, in Switzerland, in Russia. Awarded many awards and prizes: three times awarded by the Polish Academy of Science for the best book of the year in the field of social sciences and four times - by the Minister of Science.

Raised two children and three dogs.

Henryk Sterniczuk - Professor of management and international business in the University of New Brunswick in Canada. For many years the Director of MBA in the University of New Brunswick and Professor of the Faculty of Business in the Pennsylvania State University in USA. In 1990s counsellor to the Minister of Ownership Transformations and founder of the Centre for Privatisation in Poland, of the Institute for Privatisation and Management in Russia and of the International Business Institute in Ukraine, Belarus and Kazakhstan. The President of the Supervisory Board of Polish Management Research Foundation and the President of the Scientific Council of IBD Business School.

His scholar interests also include, among other things, social and cultural background of the process of generating innovation in post-industrial innovative societies.

Author and editor of an extensive monograph entitled Nadzór korporacyjny (Corporate Supervision) which comprehensively presents the most important issues concerning formation, in Poland, of the principles of corporate order and best practices in companies.

Ruth Taplin - The Centre for Japanese and East Asian Studies of which Prof. Taplin is Director won Exporter of the Year in Partnership in Trading/ Pathfinder for the UK in the year 2000. She received her doctorate from the London School of Economics and has a GDL in Law. She is the author/editor of 21 books and over 200 articles. She wrote freelance for The Times newspaper for 9 years on Japan, Taiwan, Korea and was a consultant to the Federation of Electronics Industry for 9 years. Prof. Taplin studied Japanese at Durham University over 20 years ago as part of a special course for future leaders in the Japanese field in the UK.

Some of her books are, Decision-making and Japan - A study of Japanese decision-making and its relevance to Western companies reprinted by Routledge in 2003, first published by The Japan Library in 1995; Exploiting Patent Rights and a New Climate for Innovation in Japan (London: Intellectual Property Institute 2003); Valuing Intellectual Property in Japan, Britain and the United 
States (London RoutledgeCurzon:2004); Risk Management and Innovation in Japan Britain and the United States and Japanese Telecommunications Market and Policy in Transition (both published by London: Routledge/Curzon 2005). Innovation and Business Partnering in Japan, Britain and the United States (Routledge 2006), Outsourcing and Human Resource ManagementAn International Survey (Routledge 2008). Intellectual Property and the New Global Japanese Economy (Routledge April 2009). Intellectual Property, Innovation and Management in Emerging Economies co-edited with Prof. Alojzy Z. Nowak published by Routledge in 2010. In that year she also wrote "Future Developments in the Japanese Exchanges" for the Handbook of World Stock Derivative and Commodity Exchanges June 2010 Mondo Visione. She visited Japan in July 2009 to carry out research and write a report on the future of Japanese securities and exchanges for this.

Prof. Taplin was chosen by Routledge in January 2010 as the first author of the month for the whole of Asian Studies and continues to be a featured author. Subsequent Routledge books include in 2012 Mental Health Care in Japan, Intellectual Property Valuation and Innovation: towards global harmonisation 2013, Managing Cyber Risk in the Financial Sector: lessons from Asia, Europe and the USA 2016, Innovation, Investment and Intellectual Property in South Korea: Park to Park, 2018. Prof. Taplin is occasionally invited by the United Nations to act as an innovation expert because of her entrepreneurial experience as an innovator.

Editor of the Journal of Interdisciplinary Economics for 20 years, she is now Editor of Interdisciplinary Journal of Economics and Business Law (www.ijebl. co.uk) founded by her. Professor Taplin has had a number of visiting affiliations with universities including a Visiting Professor at Osaka City University, Visiting Professor at the Faculty of Management, University of Warsaw, Poland, a Visiting Fellow at the University of Mumbai in January 2007 and in January 2008/April 2009 at the University of Bacheshir in Istanbul. In 2014 she lectured in Nepal and in 2018 was keynote speaker at MBALI conference and presented a number of seminars and workshops at a number of South African universities. She has also worked for a number of law firms specialising in IP around the world on a project by project basis.

Xiaobing Wang - a senior lecturer (Associate Professor) in Department of Economics at the University of Manchester. He received his $\mathrm{PhD}$ degree from King's College London, and his masters' degrees from the London School of Economics and the University of Birmingham. Xiaobing Wang's research is in the area of Growth and Development, Structural Change, and the Economics 
of China, with special interest in Chinese development models, and the income distribution in China. He has extensive media experience and is a frequent commentator on the Chinese economy and a wide range of global economic issues such as global imbalances and aids in Africa. 



\section{Preface}

How much free market economy and how much economic interventionism? Nowadays this question is asked and pondered not only by many economists, but also by political leaders responsible for the development in most countries of the world. What we know already is that the simplified alternative "either market or the state" is unsustainable. Poland is a country with an extensive experience in this area. In early 1990s a zero-one approach to economic theories pushed Poland onto the development model created in the Western countries. That model, while undeniably more healthy than centrally-planned economy, failed to take into account historical and social specificities of Central and Eastern Europe, including Poland. The fundament upon which we used to build Polish capitalism and welfare until quite recently consisted of a set of rules known as the Washington Consensus. That approach had seriously underrated the burden of the post-communist reality. By the way, the classic neoliberal theory also failed to work properly in a number of other Central European countries and in some countries of other regions. And still is was reckoned an inviolable axiom for a number of years, thus preventing the actual needs of the development process to be adapted to the implemented policy.

It was only the global economic crisis, starting in 2007, that gave the impulse to revise the universally acclaimed economic theories. Poland, 26 years since it had begun its systemic transformation and over 11 years since becoming the European Union member state, faced a complex challenge of bringing corrections to its economic policy. This required formulation of a new strategy of development - one capable, on the one hand, to meet the crucial domestic expectations and social aspirations, and on the other hand to effectively adapt the Polish development pattern to external demands of contemporary global economy.

The Polish reaction to the present global economic and social challenges are the concepts included in the Responsible Development Plan. One of the most serious flaws of the transformation of the economic policy implemented after 1989 was the lack of synchronization between the achievement of the goal which was the growth of Poland's GDP, and the increased welfare of all social groups in the country. Also, the development model followed over that period neglected to take ever aggravating structural disparities between regions of Poland into account. In many cases, high economic growth failed to translate sufficiently into welfare of Polish citizens and households. This resulted in the sense of disillusion, exclusion and social polarization. In the long run this tended to ricochet and undermine the rate and the quality of Poland's development. It was essential for the answers given to these challenges to include a specific social policy - well considered to provide real support to the citizens, implemented with particular care for the stability of public finance and for the rate of growth. 
While we should not emulate somebody else's systemic solutions, still it is our obligation to keep track of ideas and theories of both economists and practitioners of economy. This is necessary to be able to modernize the state continuously and with the highest standards maintained. In Polish conditions where dogmatic neoliberal solutions prevailed for many years, we should pay particular interest to theories which accept the basic assumption for the economic growth - which is effective market-based economy - and then complement it with the role of state in creating the fundaments for the stability and sustainability of the growth. This is especially relevant witnessing Polish republican traditions as well as the experience of solidarity and solidarism. Among interesting doctrines to take into account in this context there is that of New Structural Economics, the main author of which is the Chinese economist, the former Senior Vice-President of the World Bank, Justin Yifu Lin. With a little simplification, it should be observed that the key assumptions of that doctrine reveal the traps and barriers of sustainable growth that all developing countries have to face as they approach the stage and status of welldeveloped countries. However, even more importantly, the doctrine in question indicates solutions and recipes allowing to break through the middle income trap and to really catch up with the wealthiest states. The Responsible Development Plan is a good example of putting that doctrine into practice as it also emphasizes the importance of combining an efficient and competitive market economy system with the enabling state which facilitates the structural economic transformations.

Therefore, it should be appreciated that the present publication - thematically a follow-up to the previous one, published in 2017 by the University of Warsaw, Faculty of Management Press - edited by the Professors Justin Yifu Lin and Alojzy Z. Nowak, the Dean of the Faculty of Management, University of Warsaw, carries on the study of and reflection about the paramount processes of globalization, and conclusions they entail for countries like Poland. New Structural Economics is not just theory. In proposing it, Justin Yifu Lin relies upon empirical knowledge, inquiries into differences and experiences of countries which have achieved economic success going along paths different than classic neoliberalism.

We know only too well that it hardly pays off to yield to economic dogmas - even the most tempting ones. Instead, it is essential to analyze, to study and to present a variety of viewpoints in matters as important for the economic policy as the prospects of globalization or potential models of development policy. The choice of the right way depends on a number of variables peculiar to each individual country. Surely it is worthwhile to learn about new ideas, new economic theories and practice, because in the world that changes with an astonishing speed the flexibility of approach becomes one of the crucial strengths to foster development.

Mateusz Morawiecki

The Prime Minister of the Republic of Poland 


\section{Introduction}

This new bilingual publication entitled New Structural Policy in an Open Market Economy (Nowa Polityka Strukturalna a Ekonomia Globalnego Rynku), released under editorial care of Justin Yifu Lin and Alojzy Z. Nowak is a follow-up to the issues and discussion presented in a book published in 2017 by the University of Warsaw Faculty of Management Press as "New Structural Economics For Less Advanced Countries" (Nowa Ekonomia Strukturalna Wobec Krajów Mniej Zaawansowanych). Studies and inquiries concerning the New Structural Economics concept in the Faculty of Management, University of Warsaw have largely been one of benefits resulting from the presence, in Poland and in our Faculty, of Professor Justin Yifu Lin, one of its inventors and theoreticians, an advisor to the Chinese government in the area of economic development and the Vice-President of the World Bank in the years 2008-2012.

In Poland the need for analytical appraisal of both the philosophy and practice of development based upon the assumptions of the New Structural Economics seems the more justified that the policies and strategical approaches applied by the present Prime Minister of the Polish government Mateusz Morawiecki regard some guidelines resulting from that theory with much interest and approval. The government's principal program based on the Responsible Development Strategy has been consolidated by the implementation of the development strategy aiming at the achievement of such structural transformation in the economy which initiate the process of catching up with highly-developed countries by countries less advanced in their development. Poland should be ranked among the latter group.

The essence of the New Structural Economics theory and some analyses on that subject were presented in the book published in 2017, available in its entirety in the University of Warsaw Faculty of Management Press web site at: http://www.wz.uw.edu.pl/portale/wydawnictwo-WZUW/wydawnictwo/ksiazki-iskrypty. To put it very shortly, this theory argues that the economic development is a process of structural changes featured by a continuous technological innovation and industrial progress. These phenomena raise the productivity of 
labor and tend to accompany the improvements in the areas of infrastructure and institutions which contributes to reduction of transaction costs. Accordingly, the industrial policy has been an essential instrument for governments, enabling them to define priorities in terms of utilization of limited resources. This way it becomes possible to stimulate both processes - technological innovation and industrial progress - at the same time through solutions brought to inseparable problems of externalization and coordination in structural transformations.

The second, new publication mentioned at the very beginning consists of two parts. Its editors believed it was worthwhile to carefully analyze the dilemmas concerning the present economic development, together with processes occurring under conditions of globalization. Today it has become perfectly justified to search for new systemic solutions to several problems experienced on the global scale, and perhaps even make a bold attempt and consider the need for a new deal, a more equitable economic order in the world. This seems quite a complex task if not outright formidable, but it is still worth of trying. Certainly the concept of the New Structural Economics casts precious light upon a number of development-related dilemmas and contributes to explain some doubts, for example regarding the scale, the role and nature of the state's involvement in the processes of economic development.

Part one of the second book includes considerations and analyses concerning the paradigms inherent in the global economy and trade, their evident evolution and how they change. There is a prevailing belief that financialization of the global economy, largely resulting from insufficient control over financial markets, as well as effects of crises which seriously affect the societies, have contributed, among other things, to questioning the development model which is mainly based on uncontrolled markets, void of adequate regulatory support and some sort of supervision on the part of the state or of supranational organizations. We are witnessing a growing belief that at the present stage the globalization relying upon neoliberal principles (according to the Washington Consensus) calls for very profound reconsideration. But in which directions corrections should go and what should be changed out of the present state of affairs? And - is such an idea realistic at all?

In the face of such doubts it seems reasonable to first ask the question about the prospects for the global economy, both immediate and in the long run. How they are going to look like? The attempted answer is to be found in the article "What is the Future of the Global Economy?" delivered by Alojzy Z. Nowak who also considers where some additional impulses might be sought to support the development in Poland. In some segments the economic policy has already applied indications given by the New Structural Economics. However, the 
Author explicitly states that it has been the European Union that provides the sort of organization which may and indeed should increasingly act as the point of reference to the economic and social integration and - in even more broader terms - for the global order. For Poland this is one of the key conclusions.

It is within this thematic scope that the articles by Kenneth Friedman and Ruth Taplin and by Harald Sander fit. In their article "Free Trade or Unfettered National/Corporate Interest?", Kenneth Friedman and Ruth Taplin evaluate the issue of the role of tree trade in the globalized world and find a gap between the theory and the practice. This argument concerns in particular the neoclassical interpretation of free trade and its actual significance in practice. The analysis provided indicates the need of balance and restraint. On the one hand, according to the Authors, it is not right to approve of trade free of any restrictions, as postulated by the laissez-faire approach. On the other hand, it would be just as hard to defend the attitudes of autarchy or an aggressive mercantilist selfpromotion of national and corporate interests. Moreover, an important role in these relations is played by intangible assets such as intellectual property rights and the evaluation of their value in the context of globalization.

Harald Sander in his article entitled "A European Policy Agenda in and for the New Global Economy" emphasizes that following a period of almost thirty years of hyper-globalization, since the time of the global financial crisis of the years 2008-09 the global process of economic integration lost most of its momentum. However, according to the Author, it would be premature to announce death of globalization - rather than that, the process of globalization is changing its character. The key characteristics of the "new global economy" include: digitalization, the rise and dramatic rate of growth of superstar firms, the rise of emerging economies, and the changing geography of global finance. At the same time, the distributional consequences of both hyper-globalization of the past and the key structures of the new global economy have the potential of undermining or even destroying political support for globalization and have been linked to the rise in populism in advanced countries. This means that consequences of the new incarnation of the globalization and political reactions thereto are certainly going to rank among factors that determine the future of Europe. Conclusions from the arguments presented in both articles indicate convincingly that globalization is not a process sustainable in itself. Without being adequately managed, globalization and its distributional consequences will tend to undermine its own foundation i.e. the faith in open markets, societies and borders.

Andrzej Sopoćko in his article "Secular Structural Processes. Unexpected Results" analyzes the crucial processes that determine the present system of 
manufacturing and distribution, i.e. globalization, securitization, digitalization and artificial intelligence. The Author describes their effects, in particular in large corporations, to conclude as follows: "Social change seems to be currently heading towards a bipolar society, that is one in which there is a group of rich people and the rest - not at all a poor one, but separated from the former by a significant income band. This means the reduction of the middle class (in statistical terms), which, unlike in previous epochs, is becoming less and less significant for the development of civilization. The main driving force behind this process is the ongoing revolution of digitization and automation".

In the article entitled "Control of Capital Against the Middle Income Trap" Kazimierz Ryć believes that many national economies are dominated by foreign corporations that invest labor-intensive production processes in these countries, using cheap labor. The subordinate role of local production has been strengthened by the globalization process. These economies may be in the trap of medium development, and currently operate in a peculiar lower league of the world economy. The Author's pivotal statement is that the "inferior role of local subcontractors is due to the fact that they do not participate in the capital ownership of companies and thus have little influence on the power of international corporations. Improving their position requires active policy of states, including the control of gross capital flow structure".

Second part of the book in question starts with the article of Justin Yif Lin and Xiaobing Wang entitled "The Facilitating State and Economic Development. The Role of the State in New Structural Economics". The Authors deliver a profound analysis of the concept of growth and role of the state in the economic growth development together with their influence upon institutional transformations, from perspective of the New Structural Economics. Their argument is that economic structures - including the structure of technology and industry, and hard and soft infrastructure - are endogenous to the endowment structure, which is given at any specific time and changeable over time. They advocate a state to facilitate structural change by using industrial policy to overcome market failures. Such efforts should support industries with latent comparative advantages in becoming competitive in the market. The state should pragmatically prioritize the use of its limited resources and implementation capability to create enclaves with favourable infrastructure and institution to jump start a dynamic growth in a country beset with poor infrastructure and institution network. Therefore, in each publication the Authors provide new studies and considerations in favor of the statement about strengths and benefits of the New Structural Economics.

The article contributed by Grzegorz Jędrzejczak and Henryk Sterniczuk, entitled "The Use of the New Structural Economics for Modernization and Increasing 
the Innovativeness of the Polish Economy”, also concerns the assumptions and practical guidelines given by the New Structural Economics. According to the Authors, ultimately, the deciding factor for Poland's modernization success will be the pro-modernization attitude of business entities, employees, and consumers (hence the whole society). The New Structural Economics Apparatus can be helpful in strengthening the role of the state in meeting the challenges the Polish economy is facing, but we must be aware that the application of NES may face many important challenges and limitations. First of all, large companies needed to create an innovative development coalition are either owned by foreign corporations or remain state property. Secondly, few Polish small and medium-sized enterprises grow sufficiently to undertake the effort of global competition. Thirdly, society, including business entities, is suspicious of state institutions, and the state is very distrustful about public-private projects. And finally, fourthly, Poles after years of scarcity want to consume and not save, thus they are not prone to promises to improve the future standard of living in exchange for disciplined serving the interests of the state and corporations.

Marian Górski and Patrycja Chodnicka-Jaworska in their article "The Process of Catching up with the Economic Development of OECD Countries and the Role of Foreign Direct Investment in this Process" consider the impact of FDI upon the economic growth. While they admit that foreign direct investments are obviously only one of several factors driving that development, they insist that the inflow of direct investments positively affects the rate of economic growth, and economic growth encourages foreign investors to invest. This means that FDI operate pro-cyclically. They support economic growth, but also deepen recessions and decrease in GDP. If the slowdown or decline in the economic growth rate occurs as a result of internal or external shocks, the reaction of foreign investors deepens this decline. This phenomenon occurred very clearly in 2018 in the case of Argentina and Turkey.

Beata Kozłowska-Chyła involves in an extended analysis of "Legal Environment for Foreign Investments in Poland". The Author considers the Business Constitution introduced in Poland and concludes that: "Normative reforms in the national legal order brought in Poland by the Business Constitution in the area defining organizational and legal conditions for foreign investments on the territory of the RP should contribute, through their improved transparency and regulatory consistence, to alleviation of barriers hindering foreign capital's access to the Polish market. In this respect Polish legislator actually implements the Community directive on services and legal conditions provided thereby are intended to foster capital mobility and intensified economic cooperation with foreign business. The profound reform of Polish commercial law, carried out 
recently in order to improve legal and economic conditions for business and to facilitate relations between the business and the state, should also increase the attractiveness of Polish market for foreign investors".

According to Michał Kurtyka, opportunities for growth may be found for Poland also in another field. The Author, who has also been a member of Polish government, is quite consistent in advocating the importance of searching for new impulses for growth to turn them into value-added for the economy. Michał Kurtyka has been for some time already a proponent of strengths and benefits potentially resulting from the electromobility. In this article, focusing on that area, he reiterates five success factors for the development of motor car industry, depending on the state situation. These are: the strength of traditional car companies, social expectations, job creation potential, internationalization possibilities, and the ability to incubate new entities. From the initial analysis, which requires further development and verification, it appears that countries such as China at the start seem to be in a privileged position to make the most of the potential of new mobility.

Such a diagnosis, but related to China, could most certainly be approved by Bogdan Góralczyk - Professor in the Centre for Europe, University of Warsaw, an expert in political science and sinologist. In his article entitled "Poland on the Route of the Chinese Silk Road: A Chance for Development or Just a Challenge?" Bogdan Góralczyk describes the attitude respectively assumed toward that project by the elites in the European Union member states, in Central and Eastern Europe targeted in another Chinese strategy called 16+1, and in Poland which is not directly situated on the Silk Road. What, then, has Poland done to take advantage of that opportunity? From an analysis provided in the article one may conclude that relatively little was done, despite rather noticeable Chinese presence in our country and significant interests vested therein. Unfortunately, from Warsaw's perspective Silk Roads rather remain a potential, a chance scarcely taken that new and real opportunity for growth. In order for this to change, political will is essential - something that seems to be missing now. It would be a pity if nothing happens in this respect soon.

The second publication we present to our Readers - Polish as well as foreign - is intended to stimulate discussion about the subjects it considers. Many views and arguments put forth in it deserve just this - taking up and discussing to contribute deepened and diversified perspectives. The topic of the present condition and prospects for globalizations are the perfect example of this. It is absolutely worthwhile to analyze the assumptions and define potential benefits from the New Structural 
Economics, along with the possibilities of applying its guidelines in countries wishing to make better progress in catching up with the most advanced economies. The book also contains firm and justified statements about the opportunities and impulses for the development of Poland. While it is mainly addressed to scholar environment, it would be very important and desirable for the book to also find its way to broader groups of readers.

FROM THE EDITOR 

PART ONE 



\section{ALOJZY Z. NOWAK}

\section{What is the Future of the Global Economy?}

The article addresses issues related to the current stage of globalization. It analyzes the main causes of the economic and social anti-liberal counter-revolution and emphasizes its influence on the newly emerging shape of the global economic order. The financialization of the world economy, which is largely the result of uncontrolled financial markets, as well as speculative bubbles that are very painful for the population, has contributed, among other things, to the questioning of the development model based mainly on markets, without proper regulatory and control support from the state. If there is an ever-growing conviction that at the current stage of economic development, globalization based on neo-liberal principles should be thoroughly thought through, then what direction should the corrections or changes in the current state take. The author shares the viewpoint of Joseph E Stiglitz that the European Union is such an organization that can and should become a reference point for economic and social integration, and thus for the newly emerging global economic order. Increasing the integration of the political, regulatory, and stimulating role of the state in the economy does not mean substituting market competitiveness with protectionism and economic nationalism.

Keywords: Globalization; Anti-liberal Counter-revolution; Development Paradigm; European Union; New Structural Economics.

\section{Introduction}

The large-scale intervention of the final lenders (central governments and central banks) has ended the escalation of the loss of financial liquidity by the vast majority of the world's main economic and financial entities (commercial banks, investment funds, insurance funds, etc.). It caused an increase of optimism in the global economy. According to the latest forecasts by the Organization for Economic Cooperation and Development (OECD), the global economy will grow in 2018 , but also in 2019 , by 3.9 percent, which is the highest since 2011. That acceleration of pace will mainly result from the revival in trade 
and investments ${ }^{1}$. However, the opinion of one of the most prestigious British economic newspapers seems to be characteristic as it predicts that "globalization has survived many things, but the invasion of mercantilist populism may be the biggest challenge for decades. The year 2018 is not disastrous for international trade, but it may turn out to be a year of dreadful waiting for the outbreak of trade wars" (Financial Times, 2018).

There is a serious concern that more and more governments, recognizing the weaknesses of the current stage of globalization, may overprotect their economies from foreign competition, in the hope this will bring good economic and social results.

There is also a growing question about the role of the state and the market in economic processes. The previous global financial crisis has placed in the center of attention, among others, the issue of controlling international capital flows. Now, in particular in the case of emerging economies, there arises the question of the appropriateness of introducing specific tools for controlling capital transfer (Wojtyna, 2017), but this topic deserves separate treatment.

\section{The Economic and Social Causes of the Anti-liberal Counterrevolution}

One of the most important analytical centers in the world - The Economist Intelligence - believes that the potential problem lies also in the fact that current and future activities of President Donald Trump are in line with the current trend in the global economy. Namely, more and more countries are openly talking about closing their economies to foreign competition or at least concentrating more on using their own resources.

However, the problem is much more serious and deeper. In the book Nowy Pragmatyzm kontra Nowy Nacjonalizm (New Pragmatism versus New Nationalism), Grzegorz W. Kolodko aptly notes that the socio-economic phenomena and processes currently occurring in the world are becoming more complicated and conflict triggering (Kolodko and Koźmiński, 2017). He is ready to attribute them largely to social and economic imbalances, but also to demographic processes and threats to the human natural environment. In his opinion, these phenomena are not yet sufficiently explained by economic sciences, because - as he claims - the current schools of economics, especially

1 https://www.ppr.pl/wiadomosci/oecd-gospodarka-swiatowa-w-2018-i-2019-r 
mainstream economics, turn out to be outdated, inadequate, ill-prepared to tackle new problems so in this respect something new should be looked for (Kolodko and Koźmiński, 2017, p. 11).

Andrzej K. Koźmiński believes that "people all over the world are beginning to aspire to an ever-higher level of well-being, and while in past centuries they humbly accepted their fate, so nowadays there is no such consent and there is a potential for violent protest" (Kołodko and Koźmiński, 2017, p. 11).

This view corresponds to the main conclusions of the study of Thomas Piketty, who in his book entitled Capital in the Twenty-First Century states that "the dynamics of private capital accumulation inevitably lead to the concentration of wealth in ever fewer hands..." (Piketty, 2015, p. 11). Piketty concludes: "When the rate of return on capital exceeds the rate of growth of output and income, as it did in the nineteenth century and seems quite likely to do again in the twenty-first, capitalism automatically generates arbitrary and unsustainable inequalities that radically undermine the meritocratic values on which democratic societies are based." (Piketty, 2015, p. 11). He doubts that "the balancing forces of growth, competition, and technological progress lead in later stages of development to reduced inequality and greater harmony among the classes, as Simon Kuznets thought in the twentieth century" (Piketty, 2015, p. 11). In his research, Piketty rightly delves into history, because he wants to show the thesis that the American dream, or the promise of Western egalitarian capitalism, is not able to come true and nothing will change in the future. In this system, the rate of economic growth is always lower than the rate of return on capital invested. The entire society benefits from the growth, while from the profit - only the richest do (Pikety, 2015, p. 373).

Professor of European Studies at the University of Oxford, Jan Zielonka, in the book entitled Counter-Revolution: Liberal Europe in Retreat, tries to see the reasons that underlie the anti-liberal counter-revolution and the establishment of governments and political parties questioning the liberal version of democracy and market reforms based on the Washington Consensus (Zielonka, 2018). "Across Europe politics was increasingly presented as an art of institutional engineering and not as an art of political bargaining between the elites and the electorate. More and more powers were delegated to non-majoritarian institutions - central banks, constitutional courts, regulatory agencies - to make sure that reason rather than passion guided political decisions. Politics giving in to public pressure was considered irresponsible if not dangerous ... Citizens were to be educated rather than listened to" (Zielonka, 2018, p. 24).

This surprising diagnosis by a professor with liberal views, who, despite the aforementioned criticism, nevertheless believes in the revival of new liberalism, 
deserves to be quoted. We are dealing, at least on the European continent and in the United States, with clearly noticeable tendencies, which also translate into the character and architecture of the new economic and social order.

Dani Rodrik has already claimed that there is a conflict between democracy, unlimited economic globalization, and autonomy or the sovereignty of states. He argued that it is impossible for these three political goals to coexist at the level of the nation state.

The British weekly The Economist (The Economist, 2018) in the analysis of Why democracy dies recalled that in 1941 there were only few democracies in the world. By 2000, however, only 8 countries had no free elections. In studies carried out in 38 countries, 4 out of 5 persons preferred the democratic system. It was then that in 1989, Francis Fukuyama claimed "the end of history" - democracy will win - the system of liberal democracy will be universal, and the market economy will be impregnable (Fukuyama, 2009).

Today, as the weekly "The Economist" observes, we are facing a retreat from democracy. The magazine tries to cite the examples that support that statement and rationalize them. The process of this retreat clearly accelerated during the financial crisis in 2007-2009, and with the ongoing destabilization caused by migration and intensification of armed conflicts:

1) social feelings have grown that the democratic elites cannot fully or completely overcome the crisis and political and social tensions. The biggest financial crisis since the depression of the 1930s, the growing debt crisis in Europe, billions of public money transferred to the rescue of banks, deepening financial inequalities, all that frightened and frustrated millions of people;

2) there have not been many new strong leaders with democratic convictions like Konrad Adenauer, Margaret Thatcher and the founding fathers of the European Union. Instead, there were strong leaders (strongmen) who undermined confidence in liberal democracy and the current elite.

On the other hand, the new leaders (strongmen) have proposed:

- dismantling or limiting existing institutions and democratic customs;

- creating and searching for the enemy (Donald Trump considers the democratic and liberal elites as the main enemy). In return, there was a search for new elites, but those that are loyal, have qualifications, do not question the authority of the leader (also from the intellectual side). The Islamic elites, in turn, got scared of the growing role of the new secular elite - though the attack in Turkey was unsuccessful, however, it was a sign of threat to their position; 
- a new economic policy that refers to the concept of economic sovereignty and the otherwise defined national interest in the conditions of globalization processes.

\section{Questions Marks Over the International Order}

All the above considerations also lead to placing question marks over the current order in the world, in particular over the economic model. Until recently, the development paradigm was based on the aforementioned Washington consensus. It grew not only from scientific research but also from real trends occurring in the globalization process. These megatrends in the global economy are first and foremost: deregulation, liberalization, privatization, and integration. These four main tendencies, occurring in the world economy, have become the basic canon of the economic policy of many countries.

The basic guidelines of the consensus for economic policy underwent certain modifications over time, but their main core remained unchanged. In the global economy they have become a kind of developmental pattern for many countries with varying degrees of economic and social advancement. The moment of breakthrough verifying the findings of the consensus became the unexpected, both in scale and size, global financial crisis in 2007-2009. Certain theoretical assumptions of economic theories based on faith in automatic repair mechanisms of the free market failed to work. Moreover, the system, devoid of mechanisms of regulation, began to "produce" various kinds of distortions. The "errors and distortions" that appeared on the financial markets turned out to be particularly severe for the economy as well as ordinary citizens (Nowak, 2013). There were also growing social and political problems, which were previously written in this dissertation. The Washington Consensus, which grew out of neoliberal theories, was seriously questioned.

Nevertheless, unambiguously negative assessments of the consequences of its implementation are also unjustified. Examples of countries can also be found that, implementing these assumptions, experienced the internationalization of their production and distribution, transfer and import of modern technologies, IT revolution, development of new markets, etc. Economic policy, based on consensus, has become an important element of the systemic transformation in so-called emerging economies, including Poland.

However, the uncritical faith in the automatic repair mechanisms of the "free market" did not work, something that, as mentioned, the global financial 
crisis (2007-2009) showed in particular, and the effects of it - as it seems - haven't been definitively and permanently overcome. The financialization of the world economy, which is largely the result of uncontrolled financial markets, or speculative bubbles that are very severe for the societies, have contributed, among others, to the questioning of the development model mainly based on markets, without proper regulatory and control support from the state. The criticism of the model, which is based on neo-liberal principles, can be accompanied by all their other consequences: frustrations and social inequalities, political and ecological threats, which were described earlier.

\section{Characteristics of New Globalization Trends}

The considerations should be preceded by the general characteristics of new trends in the economies of the most important countries in the world and the consequences of new phenomena in the globalization process.

- The technological revolution is progressing faster. Collecting and storing huge amounts of information for analytical purposes in various fields has been practiced for a long time. Today, however, the rapid growth and availability of data (big data), and at the same time their programmed selection, lead to obtaining qualitatively new opportunities. Linking and comparing relationships, hierarchies and various interconnections, collecting and selecting data from various sources, in particular in the economic sphere, opens up new opportunities for making quick and more reliable decisions and changes in business strategies. The largest transnational corporations are benefiting from this technological revolution in the first place. They have the fastest resources to match, clean up and transform data in different systems, also to gain a competitive advantage in the global market.

- In many countries (e.g. China, India, Israel) we observe a rapid shift from imitative development to development based on innovation. This leads to bigger disputes and even conflicts, e.g. regarding the observance of copyright.

- The financial crisis of 2007-2009 has changed for good the development dynamics of traditional and newly emerging economic powers. The Asian continent is becoming one of the most important centers of the global economy. And, what is also very important - the emergence of new economic powers is not based solely on neo-liberal principles. Even the International Monetary Fund questioned the main assumptions of the Washington Consensus. 
- More and more ruthless competition on the global market takes place in a situation where natural resources on Earth are running out. But there are also opinions that even more dangerous in the long run is the lack of common concern for the protection of the natural environment and disputes over the climate policy.

- The division into beneficiaries and outsiders of modern globalization is deepening. As mentioned earlier, inequalities are growing, putting into question the basic values on which modern societies are based. It triggers rebellion and growing opposition to the practices of globalism and its uncritical defenders.

- All the aforementioned phenomena contribute to the emergence of economic nationalisms appearing to various extents in many places, and to the conviction that in the face of weaknesses and imperfections of current trends on global markets, some forms of protectionism, restrictions on free trade should be introduced, even if potentially it might lead to an outbreak of trade conflicts. This approach also underlines the role of soft and hard power of individual countries - something that seems to be slightly underrated.

That "new nationalism", as the authors of the book call it (Kołodko and Koźmiński, 2017, p. 7) - "New pragmatism or new nationalism" is also characterized in the present conditions by "the revival of aggressive attitudes, views and policies that seemed to have expired once and for all after the horrific experiences of two world wars". Thus, in the global competition of an economic nature, the importance of foreign policy returns, which assumes a combination of soft and hard power (incl. political and manipulative factors) as important elements that effectively protect and strengthen the national interest.

\section{Globalization, But What Kind?}

If there is an ever-growing conviction that at the current stage of economic development, globalization based on neo-liberal principles should be thoroughly reconsidered, then what direction should the corrections or changes in the current state take? Is there a realistic concept to take advantage of the irreversibility of the globalization process with its positive results, but for an increasing number of countries in the world? And at the same time, how should the evident weaknesses and perversions, resulting in a growing dangerous social degradation and rebellion of many societies, be minimized? 
Someone who, in only one area, will effectively design and control the element and strength of contemporary markets, including primarily financial markets, and thus significantly change the processes and vectors of globalization, will deserve the Nobel Prize.

However, it is at least advisable not to make any more mistakes, as it is not worthwhile to support those scenarios of changes that may potentially create new threats, and maybe also bring new, serious conflicts. Attempts to resolve the contradictions of natural interests of corporations or states through forms of individual protectionism, the policy of imposing tariffs, replacing market competitiveness, conducting aggressive political strategies, replacing the mechanisms of transnational negotiations and arrangements, will most likely lead only to the return of national egoisms.

Meanwhile, in the global economy, where there is also objective competition and rivalry for national interests, nation states are doomed to failure, because through real danger of isolationism or separation, these countries have much less opportunities to realize their interests. This applies even to such powerful and leading countries as the United States. Even if until quite recently this seemed impossible.

Increasing the regulatory and stimulating role of the state in the economy - as a necessary postulate to reduce unfavorable processes on the global market - does not mean choosing to limit integration and global trade or the attempt to replace market competitiveness through protectionism and economic nationalism. With all its shortcomings, the integration and free flow of technology, capital, and workforce is one of the strongest development impulses on the scale of countries, regions and the world. "A bureaucratized almighty state is just as unacceptable as a total free market" (Nowak and Ryć, 2017, p. 81).

\section{Where to Look for Additional Development Impulses?}

If the attempt to replace the existing order through various forms of hegemony of its main actors, and not through attempts at consensus, would be implemented, then the global economy would have become an even more serious cause of global conflicts. Globalization processes should therefore be subject to greater control by transnational organizations or through legal and other regulations that will be agreed by consensus or at least by most states. It will be extremely difficult to accomplish. Realistically assessing, the hope that 
global "new pragmatism" is possible on the part of major actors in the global economy seems to be in vain. Therefore, it is worth to look for solutions that are proven not so much in the global context as in the regional one.

\subsection{Let Us Look at the European Union}

The European Union is such an organization that can and should become a reference point for economic and social integration, and thus more broadly - for global order.

Nobel Prize winner, Joseph E. Stiglitz, in the book entitled The Euro. How a Common Currency Threatens the Future of Europe (Stiglitz, 2017), shows convincingly how the current solutions, especially in the euro zone, contribute to creating discrepancies rather than cohesion in the European community and asks whether Europe can develop without the euro. Unlike most American economists, Stiglitz positively considers how to create a euro zone that will work. He emphasizes his hope that what he proposes will contribute to the implementation of solutions that will provide the continent with prosperity and "support our solidarity". However, he also assumes that if it is impossible to carry out the reforms that he proposes, "Europe must decide to abandon the euro in order to save the project much more important - a political integration project, important not only for the Old Continent, but for the whole world" (Stiglitz, 2017, p. 69).

Joseph Stiglitz is convinced that if the common currency is to work, then "we need more Europe". He specifies that he does not right away want a federation in the shape of the United States, where two-thirds of all public spending takes place at the central level, but definitely an increase in the current level of integration. A more efficient Common Market and free migration require "more Europe". All the more so the common currency requires "more Europe" (Stiglitz, 2017, p. 69). The plans of reforms and thorough changes proposed by him, which are supposed to lead to the saving of the euro zone and the European project, deserve a separate treatment, because the euro zone countries without further reforms, but without acceptance for them, will still be exposed to deep divergences and conflicts.

J. Stiglitz, however, looks at the European Union and the euro zone more broadly - in the context of globalization. He writes that "there is still a debate going on; what are the conditions for successful globalization. What to do if it does not proceed as we would like it to do? What are the costs and who benefits from it? Who is losing? In this sense, Europe's successes and failures are a good lesson for the future - both in terms of regional integration and this learning at 
the global level ...". Stiglitz, on the example of the European Union, emphasizes that "economic integration (globalization) will fail if it leaves political integration behind. Therefore, there is a growing need for collective actions - so as to be sure that the mutual benefits will be greater than the damage caused to each other" (Stiglitz, 2017, p. 69). With all reservations regarding the current stage of the functioning of the European Union and the euro zone, Joseph E. Stiglitz, treats the European Union as an important project, important not only for the Old Continent. As he emphasizes, "the success of the European project lies not only in the interest of Europe".

European regionalization can be seen as an important element of globalization. However, the UK's exit from the EU and the incompletely overcome effects of the financial crisis of 2007-2009, or the shortcomings of the euro zone, raise certain questions about following the European development model. All the more so that new Asian economic powers emerged that made the Asian continent one of the most important centers of the global economy and thus changed the vectors of globalization.

\section{Conclusions}

The benefits of integrating the Polish economy with the world economy within the World Trade Organization (WTO) and the European Union, and participating in the globalization process also entailed some negative phenomena, which should be treated as costs. However, the overall balance of benefits outweighs the costs.

As a country in the process of catching up with the most developed countries, Poland is also reviewing widely accepted economic theories. It looks more closely at and draws practical conclusions from the experience of those countries that have achieved economic success, not following the classic path of neoliberalism. However, it pays much more attention to economic development as a process of structural changes and industrial policy, which is an important tool for setting priorities in the use of limited resources. Hence the interest of Polish authorities in the doctrine of the New Structural Policy, of which one of the most important authors is the Chinese economist Justin Yifu Lin. The essence of this doctrine lies in the fact that the factor that determines the success of development is the state that enables this development by pursuing an appropriate industrial policy. As Justin Y. Lin points out, the economic development is a process of structural change. The desired industrial policy should therefore be aimed at 
facilitating the development of industries with hidden competitive advantages, but it should also help companies to get out of those industries in which the country loses its comparative advantage. In a competitive market, governments should reward enterprises for adding value to the public domain, developed by the first initiators in new industries - those in which the country has hidden comparative advantages - but also to provide and coordinate support for hard and soft infrastructure to reduce transaction costs (Lin, 2017, p. 199-200).

In certain segments of the economic policy, Poland is currently using the New Structural Economics guidelines, in particular through a more active role of the state, removing investment barriers to make up for technological delays in many important sectors of the economy. Under conditions of the global economy, Poland wants to free and activate the existing growth potential, and thus achieve developmental success. Therefore, it is looking for solutions that will allow it to find itself in the changing realities of the global economy in the most beneficial manner.

\section{References}

De Grauwe, P. and Ji, Y. (2018). Inżynieria finansowa nie ustabilizuje niestabilnej strefy euro. Obserwator Finansowy, 19 April.

Financial Times. (2018). Komentarz redakcyjny, 28.06.2018.

Fukuyama, F. (2009). Koniec historii. Kraków: Wydawnictwo Znak.

http://globaleconomy.pl.

https://www.ppr.pl/wiadomosci/oecd-gospodarka-swiatowa-w-2018-i-2019-r.

Kołodko, G.W. and Koźmiński, A.K. (2017). Nowy Pragmatyzm Kontra Nowy Nacjonalizm. Warszawa: Wyd. Prószyński i S-ka.

Krugman, P. (2008). The Return of Depression Economics and the Crisis of 2008. December. USA: W.W. Norton\&Company Inc.

Lin, J.Y. (2017). Nowa Ekonomia Strukturalna dla gospodarek doganiających. In: J.Y. Lin, A.Z. Nowak (eds), Nowa Ekonomia Strukturalna wobec krajów mniej zaawansowanych. Warsaw: Wydawnictwo Naukowe Wydziału Zarządzania Uniwersytetu Warszawskiego.

Nowak, A.Z. (2013). Współczesny świat w erze turbulencji. In: J. Bogdanienko, W. Piotrowski (ed.), Zarzadzanie: tradycja i nowoczesność. Warsaw: PWE.

Nowak, A.Z., Wojtaszczyk, K.A. and Zamęcki, Ł. (2016). Poland in the European Union. Coleccion Universidad 8. Madrid: Schedas.

Nowak, A.Z. and Ryć, K. (2017). Polityka $w$ regionach $w$ warunkach globalizacji. Warsaw: Wydawnictwo Naukowe Wydziału Zarządzania Uniwersytetu Warszawskiego.

Nowak, A.Z. i Lin, J.Y. (2017). New Structural Economics for Less Advanced Countries. Warsaw: Wydawnictwo Naukowe Wydziału Zarządzania Uniwersytetu Warszawskiego.

Nowak, A.Z. and Taplin, R. (2010). Intelectual Property, Innovation and Management in Emerging Economics. London: Routledge. 
Piketty, Th. (2015). Kapitat w XXI wieku. Warsaw: Wydawnictwo Krytyki Politycznej.

Stiglitz, J.E. (2006). Making Globalization Work. USA: W.W. Norton\&Company Inc., September.

Stiglitz, J.E. (2008). The Triumphant Return of John Maynard Keynes. Guatemala Times, 5 December.

Stiglizt, J.E. (2017). Euro. W jaki sposób wspólna waluta zagraża przysztości Europy. Warsaw: Wydawnictwo Krytyka Polityczna.

The Economist. (2018). Why the democracy dies, 16 June, No. 12.

Wojtyna, A. (2017). Nowa faza dyskusji o kontroli międzynarodowych przepływów kapitału. Gospodarka Narodowa, November - December.

Wojtyna, A. (2008). Współczesna ekonomia - kontynuacja, czy poszukiwanie paradygmatu. Ekonomista, 1.

Zielonka, J. (2018). Kontrrewolucja. Liberalna Europa w odwrocie. Warsaw: PWN. 


\section{Free Trade or Unfettered National/Corporate Interest?}

There is a gap between theory and practice when it comes to assessing the role of free trade in a globalised world. This is especially true in relation to the neo-classical interpretation of free trade and what it actually means in practice. We explore an analysis which advocates moderation, neither the unbridled free trade implicit in laissez faire nor autarky nor aggressive mercantilist selfpromotion of national and corporate interests. The intangible assets of intellectual property rights and their valuation within the framework of globalization is an important part of the equation and hold both positive benefits and negative implications within the US and globally. If the balance among forces is not maintained the losers are labor, government, democracy itself, the environment and consumers.

Keywords: Free Trade; Globalization; IPR; Valuation.

\section{Introduction}

It may be that the area of economics in which theory and practice are most diametrically opposed is free trade.

In theory, free trade should, must, benefit all parties involved. The grounds for this should be intuitively obvious to the most casual observer of economics. One obvious consideration is autonomy. If a trade were not beneficial to a party, that party would simply not engage in the trade.

An independent consideration stems from David Ricardo's notion of comparative advantage. If each party produces what it can produce with relative efficiency and trades for other goods and services, total production will be greater and all parties could be better off. Moreover, such trade allows for specialization, which should increase efficiency. In short, free trade is an engine of Pareto optimality, leading to economic distributions such that it is impossible to make anyone better off without making others worse off.

In practice, the side of the road to universal benefit is littered with failures. Countries that abided by the free market, free trade, Washington Consensus 
grew more slowly, or not at all. The countries that staged economic miracles, including the United States in the nineteenth and twentieth century's, all rejected free trade in favor of some measure of dirigisme, including high tariffs and government support for value-added sectors.

The winners all regarded comparative advantage not as a given constant, but as a dynamic variable, and they forged their own comparative advantages. Even the United States, influenced by Alexander Hamilton, imposed heavy tariffs, invested in banks, canals and manufacturing, refused to pay royalties on intellectual property (Cohen and DeLong, 2016). Today, it would create an uproar if royalties on Intellectual Property Rights (IPR) were not paid.

In fact, IPR and the valuation of the actual worth of intangible assets is playing a central role in the reason for the United States under President Trump initiating a trade war with higher tariffs being imposed on competitors, including allies. US IPR is highly valued by countries who do not have the expertise or funds to create their own military or business technology to operate on a competitive global basis. Smugglers, mainly from Iran, North Korea, Russia and China regularly try to steal and sell advanced American technology to hostile countries, including blueprints of patents that can be used for weapons and espionage.

In a recent example, a Texas businessman, Peter A. Zuccarelli who was working with a smuggling group headed by a Pakistani-born US citizen was paid US $\$ 1.5$ million to buy special radiation-resistant circuits for space programs in China and Russia. Documents shown in court proved that Mr. Zuccarelli had created fake shipping documents while mislabelling the circuits as parts for touch-screen computers. He was sentenced in January 2018 to four years in prison.

This tendency for IPR theft related to military technology by adversaries of the US has increased far beyond levels known during the Cold War era. (Nixon, 2018).

China has been viewed by many US policy makers as a nation practicing a dangerous innovative mercantilism that steals American IPR and trade secrets to further its quest for global economic and political dominance. China has been breaking World Trade Organisation rules since joining in 2001 by stealing IPR through any means available but mainly through cyberattack (Taplin, 2016).

Therefore, when we are assessing issues concerning free trade, IPR, and globalization it needs to be asked whether it is a question of free trade for all or one of unfettered national interest. Along similar lines, the historic and ongoing use by countries of any trade policy to their own advantage or to impose free trade policies favourable to themselves on weaker countries, combined with the 
practical failure of free trade policies, may lead us to question the underpinnings of free trade theory.

\section{Blind Spots in Free Trade Theory}

The theory, in the spirit of non-interference, laissez faire, plausibly insists that any restrictions imposed on trade must be self-defeating. In practice, all the successful countries have ignored that insistence with impunity. How could practice differ so radically from theory?

An answer may turn on a number of blind spots in the theory. If one accounts for these, then one may not be deceived by the appearance of free trade leading to Pareto optimality, much less universal benefit.

One blind spot is the assumption of autonomy. For centuries, European countries traded primarily with their colonies. That trade was highly unequal, with the European countries importing low value-added commodities and exporting relatively high value-added finished goods. The trade was often enforced by the threat of (or actual) violence, and the elite rulers of the colonies were often put and kept in their positions of authority by the European powers. The trade may have benefitted those elites, but not the majority of their countrymen.

This pattern has persisted even after most colonies had gained their freedom. Developing countries were presented with 'There Is No Alternative,' and forced to engage in highly unequal agreements, with the implicit threat of economic sanctions. They had no choice but to acquiesce to unfavorable terms.

A separate blind spot is that comparative advantage may be dynamic. Countries that now advocate, even insist on, free trade are those that those that hold comparative advantage in high value-added, often capital-intensive, sectors. These nations appear to have forgotten that they had achieved that comparative advantage by rejecting free trade and forging their own comparative advantage. (But they seem well aware that the imposition of free trade on other countries may facilitate their continuing dominance.)

If comparative advantage is dynamic, then free trade may not lead to Pareto optimal distributions. Countries forging new comparative advantages would drive competition into more value-added sectors, often requiring the protection of IPR. Potential productivity gains in these sectors tend to be larger, driving total wealth higher than it would otherwise be. History appears to bear out this claim. (Americans, in particular, might consider what their country's - and global - GDP would be if the country had remained primarily 
a producer of agricultural raw materials and had not ventured into finance, industry, technology, and the sort of innovative practices protected by IPR.)

Yet another cause of Pareto sub-optimality is short-term capital flows. Contrary to the classical picture, prices of investment vehicles - including currencies - do not fluctuate around stable equilibriums. Investors often buy a vehicle because it is appreciating, or sell it because it is depreciating. This amplifies price swings and has led to bubbles and collapses. Large swings in currency values exacerbate uncertainties surrounding long-term capital investment, especially in innovative Research and Development (R\&D). This negatively impacts economic growth, leading to long-term Pareto sub-optimal distributions.

\section{The Dubious Optimality of Pareto}

Independent of these considerations, there are serious problems with Pareto optimality itself. A slave society may well be Pareto optimal, for it may be impossible to both free the slaves and adequately recompense the owners. Moreover, there is evidence that a slave economy may be more efficient than one based on free labor (Fogel and Engerman, 1974). (This is plausible, as the threat of being killed or tortured may be an effective incentive to work harder.) One could, in principle, redistribute the products of that increased efficiency to make everyone better off. That would make free societies, less efficient than slave societies, Pareto sub-optimal.

There may be a reflection of this in the free trade issue. Even if free trade, like slavery, is more efficient, a positive-sum game, more than $100 \%$ of the gains may be captured by a few players (just as in slavery), leaving the rest with losses. The mere fact that it is possible to redistribute to make everyone better off does not guarantee that such redistribution will be undertaken, or even attempted.

These are serious problems. Any of these would nullify the advantages claimed by free trade advocates. Yet many in the economic community have refused to address, or even countenance, them (especially the consequences of a lack of autonomy, dynamic comparative advantage, and the deficiencies in Pareto optimality).

These considerations pull the free trade debate in opposite directions. At a superficial level, free trade appears to benefit all. But at a deeper level, the appearance vanishes. The longer-term dynamics of forged comparative advantage may outweigh any immediate advantages of free trade. The destabilizing effects of short-term speculative capital may make investment less attractive. And 
even if free trade were to increase total production, the deficiencies in Pareto optimality may leave most people poorer.

Practically, important trade agreements are conducted in secret, by and for powerful corporate interests. These typically seek to capture as much as they can of any benefit. Even if an agreement passes the test of increasing average productivity and total production, the capture of more than $100 \%$ of the benefits leaves the rest poorer.

It is common that one country is the overall winner, while its trading partners are impoverished. It is also common that there are a few winners and many losers in each country. This produces advocates and opponents of free trade across a spectrum, both among countries and within countries. It is typically the case that the advocates, though fewer in number, are better organized, better financed, better connected, and more keenly focused than are the opponents. And advocates find generous support in commerce, in academia, and in politics.

The separate agenda of advocates is reflected in the power of corporate funded lobbyists in the U.S. (e.g. the tobacco industry that paid lobbyists to promote without restriction their products, despite even the Federal Surgeon General warning of the deadly effects of smoking tobacco). Or in the work of academics that "helpfully" mirror the interests of corporate funders of their research (e.g. the meat industry which encourages the maximum consumption of meat, while the bulk of research by non-partisan dieticians point to gross health risks of doing this). Or politically in the U.S. President Trump's appointing to the Federal Environmental Protection Agency individuals with direct links to the coal, oil and gas industries - individuals who seek to reverse every decision made by the former Obama Administration to protect the environment. This accelerates global warming.

\section{Four Sector Losers}

In general, globalization and free trade benefit capital at the expense of labor, governments, the environment, and global socio-political health.

Labor is an immediate casualty. Work forces in countries with relatively high productivity-adjusted wages are vulnerable to having employment moved offshore. Even the threat of replacement by a global labor force functions to dampen wages, to the benefit of capital.

Governments and their citizens are negatively impacted. Corporations, encouraged to maximize after-tax profits and free to relocate to tax havens, 
have every incentive to do so. Apple Computer negotiated an income tax rate in Ireland of $0.005 \%$ and funneled a disproportionate part of its profits through dummy corporations in that country to drastically reduce its taxes (Stiglitz, 2018). Countries, deprived of corporate tax revenue, must either cut infrastructure spending (including social safety nets) or tax their private citizens more heavily.

Among other things, re-training of labor presently in unsustainable industries is not carried out. The coal industry in the U.S. is in decline while the future of energy is renewables, which employs many more than the hydrocarbon industry and in which employees need training to have a future.

The environment also suffers, as do those who depend on the environment. Compliance with environmental regulations is often expensive. Moving facilities to jurisdictions in which environmental standards are lax lowers such expenses, increasing profits. In the U.S. lobbying the Federal government (successfully) to release oil and gas producers (the source of one-third of all methane pollution) from previous policies that legislated against the release of methane accelerates climate change, but is good for the profits of hydrocarbon producers (Davenport, 2018).

Global democracy also suffers. Global trade as a fraction of economic production began a sharp increase, from about $20 \%$ in the late 1900 s to $60 \%$ today. At the same time, many nations experienced a secular change in economic disparity. That disparity had been decreasing since the end of World War II, largely as a result of political action to create and bolster social safety nets. However, as the ratio of trade to economic output increased, the fraction of benefits going to the economic elites increased.

There may be several causal patterns here. One of these is a positive feedback loop between trade primarily benefitting capital and wealth, and wealth and capital using political clout to push for more and freer trade, along with other policies that benefit capital. This has tended to concentrate wealth.

Yet extreme economic disparity is corrosive to the set of attitudes that has long been characteristic of, and may be necessary for, democracy. As a consequence, we have had the appearance of ultra-nationalist political parties in Europe, the rise to power of fascist demagogues in several countries, and the election of a would-be fascist as President of the United States (Albright, 2018).

The resentments that have fueled these extremist movements may be inchoate. But it is plausible that considerations of increasing economic disparity, exacerbated by global free trade, have played a significant causal role. That would explain the growth of fascist sentiments after World War I and today, but not after World War II. 
'During the period between the two world wars, free-market liberals governing Britain, France, and the US tried to restore the pre-World War I laissez-faire system. They put debt collection ahead of economic recovery. It was an era of rampant speculation and no controls on private capital. All this was supposed to promote prosperity and peace. Instead, it produced a decade of economic insecurity combined with heights of inequality, a discrediting of democracy, fascist backlash, and deeper depression...

As Polanyi demonstrated in his 1944 masterwork, The Great Transformation, the disembedding of markets from their societies and resulting inattention to social consequences invariably triggers a reaction. The reaction is more often chaotic and fascistic than politely democratic...' (Kuttner, 2018, p. xx).

After World War II countries tried to learn from their mistakes following World War I. And so we had the Great Compression, a period of diminished economic disparity.

This may illustrate the stakes involved and the potential severity of consequences of heading in the wrong economic direction.

One need not be wedded to any particular form of polity to appreciate the substantial evidence that countries with pluralistic political and economic institutions have succeeded while countries with extractive institutions have failed (Acemoglu and Robinson, 2012).

Given natural feedback cycles, wealth and power tend to concentrate (Piketty, 2014), leading to extractive plutocratic autocracy. Unfettered free trade would promote such concentration, wealth migrating from poorer to wealthier countries and from poorer to wealthier people within each country. Economic policies that increase economic disparity generate a risk of setting in motion processes that lead to extreme wealth concentrations, to extractive institutions, to the detriment of nations and their citizens.

\subsection{Directions Forward}

There are many economic directions in which we could head. At one extreme, we could deny (or ignore) the criticisms of free trade and proceed as though the system is the best of all possible systems in this best of all possible worlds. At the other extreme,we could retreat into autarky. In the middle, we might seek constraints on trade that would provide protection for weaker and potentially losing parties - not only countries, but individuals with weaker hands within even the stronger countries.

The first of these alternatives, though still favored by many orthodox academic economists, appears to be waning in popularity. In part, difficulties have been 
raised with standard neo-classical theory. The assumptions underlying its basic models are palpably false (e.g. behavioral economics), and its predictive track record has been poor.

Some economists, even those who reject neo-classical orthodoxy, have responded that it is possible to refine the models to generate more accurate predictions. This is surely possible. But for any desired predictions, it is possible to find some model that will generate those predictions. More important, the mode of reasoning characterized by making assumptions (models) and generating predictions as theorems is quite different from the mode of reasoning that characterizes all sciences (Friedman, 2016; 2018). Contemporary economic theory is not a theory of science.

These considerations have led some to regard the failure of neo-classical prescriptions more as failures of theory than failures of the countries at which they were directed. The diagnosis of speculative capital flows as the cause, or at least exacerbation, of the East Asian financial crisis of 1997 shed light on an important chink in the armor of neo-classical theory.

It is common that when an extreme position seems no longer dominant or tenable, it is challenged by the opposite extreme. Many American neoconservatives had converted from the opposite, Marxian, extreme. Something similar may be taking place with trade. Many people, seemingly suddenly sensitized to the loss of jobs due to imports, overlook the gain in jobs due to exports and the opportunity to re-train in expanding sectors such as renewables. No trade, or trade on unrealistically favorable terms, is seen as the solution.

Such a position may be difficult to justify economically. But politicians often lack economic sophistication, and the notion that one's country has been victimized (by others, rather than by its own economic elites) has long been an effective tool of political manipulation. Resentment based on perceived victimhood is a powerful, if dangerous, sentiment. History is littered with the outcomes of such dangerous sentiments being promulgated.

This is not to deny victimization. Rather, the perpetrators of one-sided and unfair trade agreements have been the large and politically powerful corporations that have negotiated opaque trade deals on behalf of themselves and at the expense of citizens in their own (and other) countries. While there has been victimization, the U.S., or at least its multi-national corporations and political supporters, have typically been predator, rather than prey. But they are major contributors to U.S. political parties, and it has been easy to deflect the resentment away from them.

At a national level, executives of cigarette companies long knew their product was addictive and carcinogenic. They lied to Congress about this 
and tried to make their product even more addictive (Hilts, 1996). But at an international level, '... Philip Morris... sued Uruguay in 2010 because the country passed a regulation which required the company to disclose possible harmful effects of cigarettes on health.' (Stiglitz, 2018, p. 36)

At a national level, many communities have taken steps to protect their environments, and in particular, their water supplies. But at an international level, 'When, for example, a village in the north-central Mexican state of San Luis Potosi tried to force Metalclad, a U.S. waste disposal company, to close a toxic waste site that was contaminating the local water supply, the Mexican government was forced to pay \$16.7 million in compensation, under Chapter 11 of NAFTA. Antienvironmentalists had succeeded in burying in that chapter a provision designed to halt regulation by making it too expensive... To date, suits with claims in excess of $\$ 13$ billion have been filed.' (Stiglitz, 2006, p. 130, 197)

IPR is especially important in the drugs/pharmaceutical sector. On one hand, IPR is needed by Pharma to protect its investments in R\&D to recoup its expenses. (Dewan, 2010). On the other, Pharma companies often price lifesaving medicines out of the reach of populations of poorer countries. And they have perverted IPR to 'steal' traditional medicines long used by local indigenous populations.

At a national level, if people have long been using a product, a company that had no role in the development of that product cannot acquire patent rights. But internationally, 'In the international biodiversity agreement signed in 1992 at the UN Conference on Environment and Development in Rio, the right to compensation was recognized, but, partially under the influence of the drug companies, the United States has not ratified it. And no wonder; almost half of the 4,000 plant patents granted in recent years by the United States pertain to traditional knowledge obtained from developing countries...

What the United States was asking was, we thought, not in its own interests, nor in the interests of the advancement of science, and was certainly not in the interest of developing countries. But American and European negotiators adopted the positions of the drug and entertainment industries, and others who simply wanted the strongest intellectual property rights. (A study by the Center for Public Integrity, a government watchdog group, showed that the drug industry was the single most important influence group...)

But TRIPs was designed to insure higher-priced medicines. Unfortunately, those prices made medicines unaffordable to all but the wealthiest individuals. As they signed TRIPs, the trade ministers were so pleased that they didn't notice that they were signing a death warrant for thousands of people in the poorest countries of the world.' (Stiglitz, 2006, p. 125-6, 116, 105). 
Countries have typically been able to override patents in the case of national emergencies. But internationally, 'In 1998 President Nelson Mandela signed a law that would have permitted South African drug companies to produce generic versions of AIDS drugs. The law should have been recognized by the United States as being consistent with the World Trade Organization rule that permits 'compulsory licensing' in national emergencies. But instead, Americans at all levels of government attacked the... proposal... even though Glaxo is exploiting a drug that was invented by government employees. (AZT was discovered by researchers at the Michigan Cancer Institute and Duke University, who received grants from the National Cancer Institute.)' (Adler, 2010, p. 78-9)

Hopefully, change is occurring in the US concerning the acceptance of generic drugs, which is a positive development in relation to patents and globalization. Researchers at Harvard Medical School's Program on Regulation, Therapeutics and Law (PORTAL) in conjunction with Brigham \&Women's Hospital have produced a recent study showing that generic drug companies have been successful in approximately half of their challenges of FDA-approved pharmaceutical products through a new administrative procedure of patent validity that was created by the US Congress (New, 2018).

Yet, a patent claim before the Indian High Court by UCLA in support of large Pharma companies Pfizer and Astellas shows the other side of globalization. The prostate cancer medicine was developed at UCLA but is sold through the drug companies for as much as $20 \%$ of India's median annual income. India, which has fought to promote generic drugs so successfully, may rule under pressure from UCLA to uphold the patent claim which would make it unaffordable for millions. It has been noted that UCLA is a public institution paid through US tax payers. Student activists are trying to have UCLA drop this patent claim which has the potential to deprive billions in the developing world from affordable medicines (Branigan, 2018).

These are all examples of multi-national corporations seeking to profit at the expense of developing countries. There are other features of the global free trade marketplace that exacerbate the tilt of the playing field and may extract even more from those countries than do the corporate machinations underlying specific agreements.

Free short-term capital flows, with speculation amplifying natural cycles, function to the detriment of the underlying economies. Countries must purchase expensive insurance - foreign currencies, typically the U.S. dollar - to defend their own currencies from such swings. These dollar holdings, which could otherwise be used to fund economic development, earn minimal interest rates, while the country must typically borrow at much higher interest rates to fund 
capital development. The interest rate differentials, applied to massive amounts of capital, are a boon to the U.S. financial sector, at the expense of the countries that must purchase the insurance.

In a related issue, many developing countries have enormous amounts of U.S. dollar-denominated debt. If the Federal Reserve, for purely domestic reasons, raises interest rates, the value of the dollar - and their debt - increases. This can have a destabilizing effect on the developing economies. Pegging the value of their currencies to the U.S. dollar may not be a satisfactory solution. For it is expensive, and if the U.S. dollar is strong, the peg negatively impacts the competitive position of the developing country.

These mechanisms are often taken for granted. But they have a large cumulative impact.

This does not deny that other countries, currently the Peoples Republic of China, have engaged in predatory trade tactics, from the imposition of high tariffs to government subsidies for favored sectors to outright industrial espionage. Many countries have committed these very crimes: Singapore, South Korea, Japan, Germany (in the nineteenth century), and yes, the United States. Yet we seem unaware of this history, and while we have become attuned to the predatory institutions established by the economic leaders, we are quick to take umbrage at attempts by developing countries to gain an advantage.

An awareness of this history does not address the most promising means of dealing with such issues. But it does suggest a more functional way of framing them. Developed industrialized countries have a massive inherent advantage over those trying to develop.

Successful catching-up countries have historically adopted a variety of tactics to help level the playing field. These have ranged from currency manipulation to walls of tariffs to industrial espionage. Industrial espionage itself has ranged from standard theft to hiring well-placed developed-world experts in technology, from de- and re-engineering to demanding technology and sole rights to patents of jointly developed products in return for access to large consumer markets.

\section{Conclusions}

Can one draw a cogent distinction between those policies that may be regarded as legitimate and those that are clearly illegitimate? Independently, are there programs or partnerships, perhaps involving technology sharing, that more advanced countries could offer that would spur economic growth 
in both themselves and the developing countries? (The Republic of Korea or South Korea as commonly known has pursued just such policies between large European technology companies and innovative ROK companies being developed in their science parks, see for examples Taplin, 2018). Are there ways of stimulating additional economic growth that would benefit most people? If single countries could not capture enough of the benefits to justify their investments, could multi-national institutions provide catalysis, triggering a feedback loop in which the increased economic growth of countries has a positive effect on the growth of neighboring countries?

This sort of question may be appropriate for those seeking a middle path, trade that is reasonably regulated. This may be the wisest path, though it is the most complex and difficult.

One issue it implicitly raises is the limits of trade policy. As one example, should trade agreements include tax provisions? Should they be impediments to corporations seeking to minimize their taxes by artificially locating profits in tax havens? (One could tax multi-national corporations at the venues of final sales to consumers and at the prevailing tax rates of the countries in which the products or services are sold. This would, for example, make the income tax of an aircraft producer independent of the domicile of either itself or of the purchasing airline. In effect, countries would demand that those corporations that profit from selling them goods and services pay income taxes to them. One could institute similar taxes on investments.) That would protect governments (and citizens) from being deprived of corporate tax revenue.

Trade agreements could also protect the environment, by regarding lax environmental standards as providing an unfair advantage to producers, an advantage that may be legitimately countered by tariffs.

In a similar vein, it may be possible to insist on minimal standards for labor, regarding a violation of those standards as providing an unfair advantage that may be countered by tariffs.

Some consumer protection may be provided by demands of transparency, that countries have the right, and perhaps the duty, to test products and to publicize potential adverse safety data.

These considerations may provide minimal protections. Attention to form may yield additional substantive protections. In particular, it may be reasonable to demand not only transparency, but also meaningful representation by advocates for those who would be most likely shortchanged: labor, the environment, government, consumers. 


\section{References}

Acemoglu, D. and Robinson, J. (2012). Why Nations Fail: The Origins of Power, Prosperity, Poverty. New York: Crown Business.

Albright, M. (2018). Fascism: A Warning. New York: Harper Collins.

Branigan, D. (2018). Student Activists Swarm To Demand UCLA Drop Indian High Court Patent Claim. Intellectual Property Watch online, 6 September.

Cohen, S. and DeLong, J.B. (2016). Concrete Economics: The Hamilton Approach to Economic Growth and Policy. Cambridge: Harvard Business Review Press.

Davenport, C. (2018). Trump Administration Wants To Make It Easier To Release Methane Into The Air. New York Times, 10 September.

Dewan, M. (2010). Socio-economic changes effected by intellectual property rights: the Indian perspective. In: R. Taplin, A. Z. Nowak (Eds), Intellectual Property, Innovation and Management in Emerging Economies. Oxon: Routledge.

Fogel, R. and Engerman, S. (1974). Time on the Cross: The Economics of American Negro Slavery. New York: W. W. Norton and Company.

Friedman, K. (2016). Econoclastics 201: Meta-economics - Is Economics a Science? Interdisciplinary Journal of Economics and Business Law, 5(3), 76-101.

Friedman, K. (2018). Structural Failures and Non-structural Defects of Economic Theory. Interdisciplinary Journal of Economics and Business Law, 7(3).

Kuttner, R. (2018). Can Democracy Survive Global Capitalism? New York: W. W. Norton and Company.

New, W. (2018). Study: Generic Drug Industry Embraces Faster, Cheaper Pathway For Challenging Patents. Intellectual Property Watch online, 6 September.

Nixon, R. (2018). Smuggling of US Technology Outpacing Cold War Levels Experts Say. New York Times, 17 March.

Piketty, T. (2014). Capital in the Twenty-first Century. Cambridge: Harvard University Press.

Rodrik, D. (2011). The Globalization Paradox: Democracy and the Future of the World Economy. New York: W. W. Norton and Company.

Rodrik, D. (2017). Straight Talk on Trade: Ideas for a Sane World Economy. Princeton: Princeton University Press.

Stiglitz, J. (2006). Making Globalization Work. New York: W. W. Norton and Company.

Stiglitz, J. (2017). Globalization and Its Discontents Revisited: Anti-Globalization in the Era of Trump. New York: W. W. Norton and Company.

Taplin, R. (2016). Postscript. In: R. Taplin (Ed), Managing Cyber Risk in the Financial Sector: Lessons from Asia, Europe and the USA. Oxon: Routledge.

Taplin, R. (2018). Innovation, Investment and Intellectual Property in South Korea: Park to Park, Oxon: Routledge. 


\section{HARALD SANDER}

\section{A European Policy Agenda in and for the New Global Economy}

After almost thirty years of hyper-globalization, the global economic integration process has plateaued after the global financial crisis of 2008/09. However, this article argues that it is premature to announce globalization's death. Rather, it posits that globalization is changing its character. Key features of the "new global economy" explored are: digitalization, the rise of superstar firms, the rise of emerging economies, and the changing geography of global finance. At the same time, the distributional consequences of both hyper-globalization of the past and the key structures of the new global economy have the potential of undermining political support of globalization and have been linked to the rise in populism in advanced countries. Taking into account the political challenges emanating from globalization, the article finishes by discussing policy options for the European Union. It argues, that is not enough to address the economic and distributional issues efficiently, but that is also urgent to rebalance and democratize EU governance to give Europe the legitimization and, hence, the credibility to act globally in support of a just and stable global economy.

Keywords: Digitalization; Superstar Firms; Emerging Economies; Global Finance; Populism; European Governance.

\section{Introduction}

Globalization has been slowing down. At the same time, populism and old-style protectionism is on the rise. This article seeks to identify the major disruptions in and to global economic integration and its policy implications from a European perspective.

From the late 1980s onward, cross-border economic activities had been growing considerable faster than global production. However, after the global financial crisis (GFC) of 2008/09, this phase of about thirty years of "hyperglobalization" has given way to what some consider to be a "new normal": trade and foreign direct investment (FDI) are stalling relative to production, 
and a retrenchment of cross-border finance has been setting, especially in banking (see Figure 1). This article has two major objectives: First, it argues that it is premature to announce globalization's death. Rather, it will show that globalization is merely changing its character. Second, it will explore the implications of this "new global economy" from a European policy perspective.

Figure 1. Cross-Border Activities Relative to World GDP, 1980-2017 $(1980=100)$

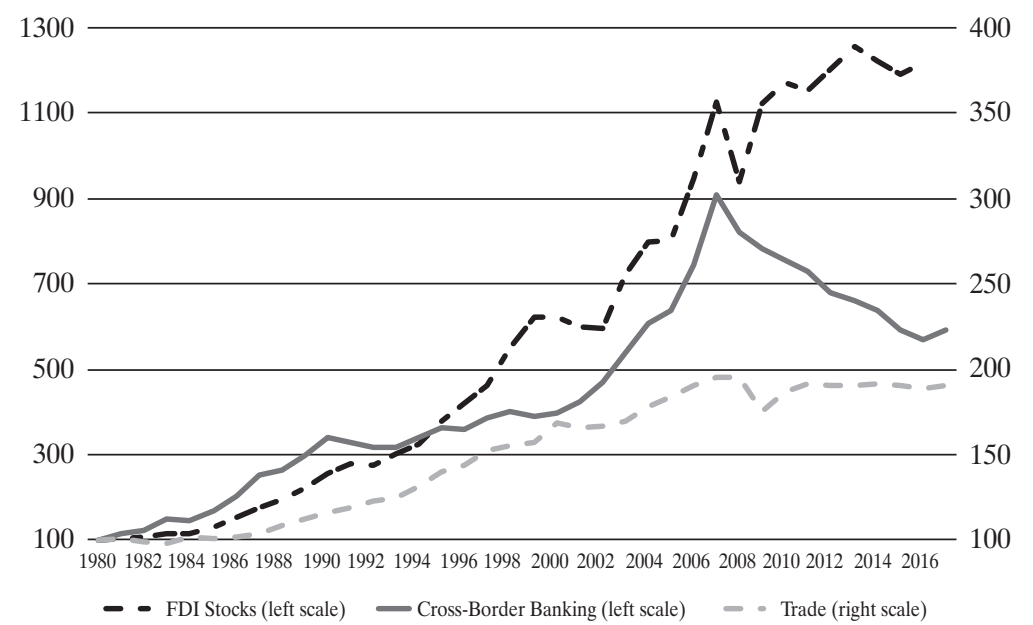

Source: Own calculation based on IMF World Economic Outlook Database (GDP, Trade), UNCTAD (FDI), and BIS Locational Banking Statistics (Cross-Border Banking). FDI stocks are measured as the average of inward and outwards stocks. Cross-border banking is measured as the average stocks of cross-border liabilities and claims.

Like in the past, the interaction of technological developments and policy will continue to determine the pace and character of global economic integration and, hence, its effects on people. On the technological side, especially digitalization and robotics will reshape the global economy as much as the steam engine has done it from 1870 to 1914, and information and communications technology (ITC) from the 1990s onward. On the political side, the opening-up euphoria of the $90 \mathrm{~s}$ and $00 \mathrm{~s}$, advocated as a panacea to many if not all economic woes by the so-called Washington Consensus (Williamson, 1990), has lost its appeal after the GFC has shown the vulnerability of financially closely interconnected economies. Additionally, as both technologies and globalization are threatening the standard of living not only of the low-skilled, but make deep inroads into the middle class, populist movements are increasingly pushing a political backlash against globalization in several advanced countries. Old-style protectionism with nationalistic undercurrents has become popular again and reminds observers of 
the sinister $20^{\text {th }}$ century interwar period that ultimately helped destroying the world economic order. Whether populism and nationalism will repeat its malign impact on the global economy will depend crucially on how policy makers will deal with the dual challenges emanating from technology and globalization.

In this article I will explore these issues from a European perspective. Section 2 seeks to identify the major drivers of current and future globalization in general, and their impact on Europe in particular. Based on this analysis, the link between globalization and the rise of populism especially in Europe is reviewed in section 3. European policy options and the quest for a reform of the European Union to deal with the emerging new global economy is discussed in section 4. Section 5 concludes.

\section{Towards a New Global Economy}

\subsection{The Rise of Global Value Chains}

From the mid-1980s onward, technology advancements in ICTs as well as a global political drive towards deregulation and opening-up economies, enabled corporations to globalize quickly. With the emergence of computer-aided design, computer-numerical controlled production and computer-aided manufacturing, value chains could suddenly be "sliced-up": the production of a product was "unbundled" in several tasks in a way that these tasks fit perfectly until final assembly takes place. Production of many goods no longer needed to take place in a single factory. These new possibilities for slicing-up the value chain are being used whenever it becomes profitable to do so. This can, of course, be done within a country or even within a narrowly defined region. In effect, domestic outsourcing is common, too. However, given the much bigger differences between production costs and the much greater variety of specialized skills on a global scale, the globalization of value chains can offer much more efficient opportunities than pure domestic ones. This also depends on one more thing: reasonable information and communication costs. This is exactly what happened from the 1990s onward: increasing possibilities for slicing-up the value chains coupled with drastically falling information and communication cost. As a consequence, value chains were sliced-up and offshored, thus giving rise to what has become known as global value chains (GVCs). A tremendous relocation of production tasks took place from the late 1980s onwards, largely driven by FDI. Emerging economies, especially in South-East Asia, that quickly understood that they 
could benefit from these investments tremendously, opened-up their economies to trade and FDI, deepened regional free trade agreements and countries like China were eager to join the World Trade Organization (WTO). Especially these countries were able to gain tremendously from this new type of "labor arbitrage" by participating in the global value chains of major industries, in particular in clothing and electronics. In Europe, the Central and Eastern European Countries (CEECs) became a significant part of the regional production networks of major West European industries, with an important role of the automobile industry. And in the Americas, the Mexican maquiladora industry involved itself deeply in the North American value chain.

It is noteworthy that global value chains are often regionally concentrated. ${ }^{1}$ For example, in the electronics industry suppliers of intermediate inputs are often also located in one region, in this case in East Asia. This creates a lot of intra-regional trade within relatively short distances, which make regional trade agreements an important policy instrument to promote the regional clusters. Only when the final product is delivered to the consumer market, trade becomes truly global. A similar pattern can be observed in the European car industry, where especially the German automobile industry has created regional production networks, in particular involving CEECs.

Since the global financial crisis, trade and foreign investment growth has slowed down. Why is globalization stalling, will it eventually revive and if yes, in what configuration? In other words, are we witnessing just a temporary halt or a structural shift? While this is partly the effect of the great recession that followed the GFC and - in Europe - especially the Euro crisis from 2010 onward, and hence eventually a temporary effect, it is also argued that GVCs have entered a stage of diminishing returns: everything that could be sliced-up has already been sliced-up. In fact, growth in GVCs has recently stagnated. While the share of foreign value added in trade has increased from $24 \%$ in 1990 to $31 \%$ in 2010 , it is now down to $30 \%$ in 2017 . But it is noteworthy that the share is with $38 \%$ still very high in Europe (UNCTAD, 2018).

However, there may be also other technological, economic and political factors behind the slow-down of trade, investment and GVC creation. To understand where the global economy eventually will go from here, I will review

\footnotetext{
This is also reflected by the so-called "distance puzzle" found in estimates of gravity models of trade. The gravity model postulates that trade between two countries is proportional to the product of the economic size of the countries and inversely related to the geographical distance that separates them. The distance puzzle relates to the finding of most gravity studies that sizeable distance effects not only still exist, but despite falling transportation and ITC costs have increased in recent times. Regional production networks go a long way explaining the distance puzzle.
} 
four major potential disruptors: digitalization through further advances in ICT, the rise of superstar firms, the (further) rise of new emerging market countries, and the emergence of new pattern of global finance after the GFC.

\subsection{Digitalization}

While ICT and digitalization has allowed the slicing-up of the value chain to an extreme amount, digitalization has more in store than just creating GVCs to change the intensity and character of globalization, namely robotization, machine learning, i.e. artificial intelligence (AI) and a potential of reducing face-to-face communication costs through virtual reality (VR) and augmented reality (AR) applications (see Baldwin, 2016).

To start with, robotization has in principle nothing to do with offshoring as a robotized production process can take place domestically or offshore. In the first case, a domestic job would be replaced by a robot, in the second case it would replace a foreign job. The matter of interest here is how robotization will impact the geography of global production. This depends on what it does to production costs: When the prices of machines (capital) fall relative to the cost of the labor that these robots would replace, a shift to machine production will take place. Here, two observations are important: First, the price of capital is indeed falling (see e.g. Nordhaus, 2015) and second, the cost of labor especially in fast growing emerging economies, like China and South-East Asia, are rising. Given that many tasks have been offshored to low-labor-cost locations, these effects can thus induce reshoring. Moreover, reshoring may be re-enforced by a market-size effect, which will shift production closer to consumers.

The important point is that intelligent robots may not simply overtake whole production process but just tasks, namely those that are most easily to robotize. In a recent paper, Acemoglu and Restrepo (2018, p. 48) model task-based automation. They argue that technologies most threatening to labor "are not those that are major breakthroughs increasing productivity greatly, but those that are "so-so" - good enough to be adopted but not so good that they increase productivity by much." As a consequence, reshoring of tasks is increasingly becoming a real phenomenon, not least in Europe. Marin et al. (2017) identify a changing pattern of offshoring, which indicates that the slowing-down of GVC trade is characterized by a new form of globalization with firms restructuring their value chains to become shorter and more local and regional. The authors also find sizeable relocation effects, not least driven by reshoring of Chinese companies. In Europe they find significantly less offshoring to southern European countries and instead a move towards China and the CEECs. 
AI is the second main potential technological disruptor. With machine learning developing fast, the regional concentration on the US on the one hand and China on the other hand is striking. In other words, Europe is largely absent in the development and in particular the exploitation of AI, which requires access to huge data to allow for machine learning. Two business models are thus dominating: the data-commercializing model of US data giants and the "state-collecting-data" model of China.

The third potential disruption may come via decreasing face-to-face communication costs as argued forcefully by Richard Baldwin (2016). Telepresence, tele-conferencing, tele-robotics, VR and AR may allow to reduce travel cost and might thus allow countries that previously were grossly unrepresented in the GVC-driven globalization of the last 30 years to develop new competitive advantages based on labor cost differentials, which finally have the potential to connect remote countries like Argentina as much as land-locked countries in Africa and Asia, which have not been part of the "great convergence" process in the global economy. These cross-border activities will take place in merchandise trade but in trade in (labor) services - another new form of globalization.

\subsection{The New Global Firms}

Rapidly growing global digital multinational enterprises (MNEs), trade in intangibles, and tax-optimizing FDI are gaining in relative importance in cross-border activities at the expense of trade in goods and FDI in manufacturing.

Figure 2. Global FDI Inward Stock by Sector, 2001, 2007, 2015 (Trillions of Dollars)

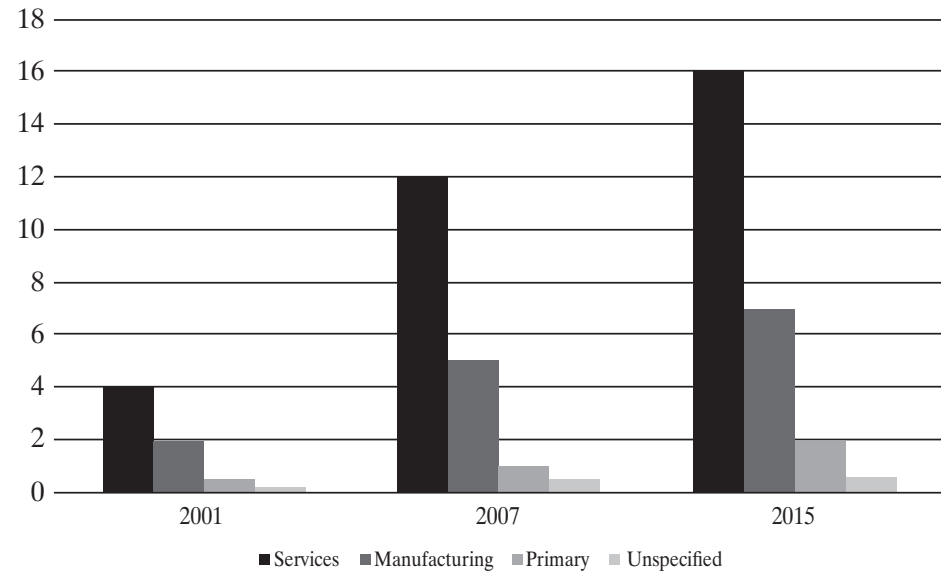

Source: UNCTAD, 2017, p. 21. 
Trade in intangibles comprise services and well as trade in knowledge. To start with the least spectacular observation, it is now well-documented that FDI in services is dominating overall with a share of above $60 \%$. Nevertheless, this number is by-and-large in line with the overall share of services in the global economy. ${ }^{2}$ However, the previous secular trend towards FDI in services has leveled-off after the financial crisis, suggesting that FDI services are often directly linked to activities in manufacturing or in the primary sector (see Figure 2). Nevertheless, as today more than half of all global FDI flows are going to developing countries and countries in transition, where the share of the service sector has been relatively low, this also signals a catching-up of the latter in services.

The structural changes are more drastic when it comes to the geography of and trade in know-how. While the global stock of knowledge and technology was in the past concentrated in advanced countries, knowledge is increasingly crossing borders and rapidly rising innovation activity in emerging economies, especially in Korea and China, as documented in a recent IMF study that uses patenting statistics (IMF, 2018). Knowledge typically travels with trade, FDI, migration and other cross-border activities. Hence, it has directly and indirectly been driven by the advancements in ICT. Participation in GVCs appears to play an important role for knowledge spillovers and patenting activity. The authors of the IMF study find that the "overall effect on patenting of the average firm is positive, with the observed 1 percent increase in GVC participation every five years explaining one-tenth of the increase in patenting in the average firm over the same period" (IMF, 2018, p. 15). Based on an additional analysis of crosspatent citations, the authors also document the rise in trade in know-how and increasing importance of south-north trade and south-south trade in knowledge.

From the perspective of the traditional innovating advanced countries, the transfer of knowledge is a two-sided sword. On the one hand, selling knowhow becomes increasingly a major source of income, hence generating direct benefits for the innovating companies. As more widely-spread knowledge can boost productivity and incomes in the receiving economy, it may also contribute indirectly to a higher demand for the innovating companies' products. The downside is, whether or not the proper price is paid for the know-how, thus compensating for eventually increasing competition.

2 It should be noted, though, that the data on the share of services is somewhat inflated. According to UNCTAD (2017: 21), a "large part of global FDI in services is in business activities, including functions carried out by holding companies and regional headquarters that are allocated to services by default, even though parent companies might operate in the primary or manufacturing sector." 
As such, the core of the issue lies in creating a fair and level playing field. The problem is twofold: First one has to strike a proper balance between innovators and imitators, and second, as it is well documented by now, trade in know-how is often used for tax-avoidance purposes via transfer pricing.

Finally, with respect to the new global digital superstar firms, especially the so-called "big five": Alphabet, Apple, Amazon, Facebook and Microsoft, five important observations need to be made.

First, superstar firms in the digital business are typically "winner-takes-all/ most" firms. The digital markets are characterized by strong network externalities and, hence, a lack of effective competition, thus generating extremely high supernormal profits.

Second, superstar firm are a strong driver behind the secular fall in labor shares. Van Reenen (2018, p. 21) notes that "large 'superstar' firms will tend to have higher profit margins and lower labor shares of value added". This, however, is not true for the typical US firm, as documented by Autor et al. (2018). Hence, Van Reenen continues to explain that "[W]hat explains the fall in the aggregate labor share and rise in the markup is a reallocation towards the larger and more productive firms". In other word, a rising share of superstar firms in the national value-added reshuffles income shares from labor to capital.

Table 1. International Footprint of Top 100 Multinational Enterprises (MNEs), 2015

\begin{tabular}{|c|c|c|c|}
\hline & Tech MNEs & Telecom MNEs & Other MNEs \\
\hline Share of Foreign Assets & $41 \%$ & $66 \%$ & $65 \%$ \\
\hline Share of Foreign Sales & $73 \%$ & $57 \%$ & $64 \%$ \\
\hline \multirow[t]{7}{*}{$\begin{array}{l}\text { Ratio Share of Foreign } \\
\text { Sales to Foreign Assets }\end{array}$} & 1.8 & 0.9 & 1.0 \\
\hline & of which: & & of which: \\
\hline & Internet Platforms & 2.6 & $\begin{array}{l}\text { Automotive } \\
\text { and Aircraft }\end{array}$ \\
\hline & $\begin{array}{ll}\text { Digital Payments } & \\
\text { and other digital } & \\
\text { Solutions } & 1.9\end{array}$ & & \\
\hline & 1.8 & & \\
\hline & E-Commerce & & \\
\hline & $\begin{array}{ll}\text { Digital Content } & 1.1\end{array}$ & & \\
\hline
\end{tabular}

Source: Based on UNCTAD, 2017, p. 170 and 171.

Third, the international footprint of digital MNEs is profoundly different from that of other MNE, as documented by UNCTAD (2017). Table 1 shows that 
they require only a share of about $40 \%$ of total assets to locate abroad to reach foreign markets and to generate $70 \%$ of their sales abroad. Hence, the relation of foreign sales to foreign assets is 1.8 as opposed to a one-to-one relationship for other MNEs. The relation is especially high for MNEs providing internet platforms, digital solutions as well as for IT firms (software and services, devices and components). As a consequence, these firms generate less investment and employment in the countries they serve with their products than non-digital MNEs.

Fourth, digital MNEs are more closely linked to their home countries than other MNEs. Moreover, they are headquartered in only a few countries, with an obvious concentration in the United States.

Fifth, the high share of foreign earnings in total earnings is often neither remitted to the home country nor used to finance foreign productive capacity, in a way comparable to non-tech MNEs (see Table 2). UNCTAD (2017, p. 174) therefore conjectures from an analysis of US MNE behavior: "The main objective is rather to minimize the tax burden by (indefinitely) deferring the payment of the tax adjustment upon repatriation of foreign earnings to the United States. Accordingly, tech MNEs incurred an average effective tax rate of 19 per cent in 2015 - significantly lower than the tax rate paid by other United States MNEs. These patterns are likely to apply to digital MNEs as well, given the common characteristics they share with tech MNEs". ${ }^{3}$

Table 2. Foreign Earnings, and Effective Tax Rate of United States MNEs in UNCTAD's Top100 MNEs, 2015

\begin{tabular}{|l|c|c|c|}
\hline & $\begin{array}{c}\text { Share } \\
\text { of Total Foreign Earnings }\end{array}$ & $\begin{array}{c}\text { Ratio of unremitted foreign } \\
\text { earnings to tangible assets }\end{array}$ & Effective tax rate \\
\hline Tech MNEs & $62 \%$ & 6 & $19 \%$ \\
\hline Other MNEs & $23 \%$ & 1 & $27 \%$ \\
\hline
\end{tabular}

Source: Based on UNCTAD, 2017, p. 174.

What do have all these trends have in common? First, trade in services, knowledge and digital products is highly skewed. Secondly, they strongly demonstrate the need to create or maintain a fair and level playing field for trade in services, know-how, and data. Catching-up, build-up and digital strategies are therefore part and parcel of new industrial policies. The crucial question is how to reconcile these policies with the fair- and level-playingfield argument? And thirdly, they point to the need to address tax avoidance

3 UNCTAD cautions that these results are strictly linked to the US tax system and may change with the intended changes of that system. 
strategies. A recent study by Tørsløv, Wier and Zucman (2018) has estimated that almost $40 \%$ of multinational profits are shifted to low-tax countries each year. Profit shifting is largely taking place via transfer pricing and is highest amongst U.S. multinationals. However, the tax revenue losses are estimated to be largest for the EU and developing countries.

\subsection{Rising Countries and the Great Convergence}

Participation in GVCs has brought a couple of emerging economies a dramatic rise in the standard of living, and an equally dramatic reduction in poverty. Moreover, the rise of these countries is changing the global balance of economic power, thus leading to a multi- or at least three-polar world (see Figure 3). While in terms of current US-\$, the EU and USA are still ahead of China, however, in terms of purchasing power, a truly three-polar world has already emerged.

Figure 3. Share of World GDP: EU, USA and China, 1990-2016
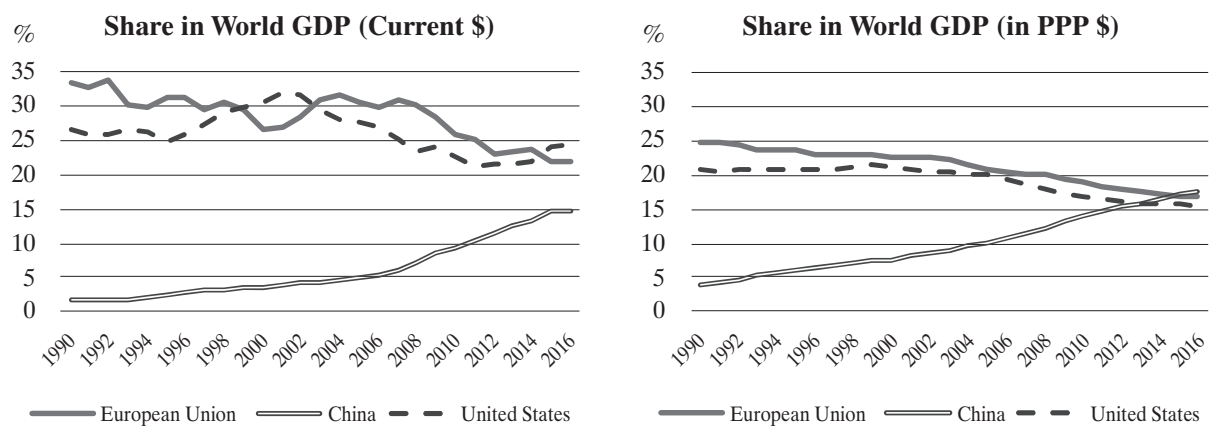

Source: Own calculations based on World Bank, World Development Indicators.

Will the "great convergence" continue, and what are the implications for the global economic geography? Three considerations are important here: First, will other countries be able to follow the model of China; second, do new technologies hold new opportunities for convergence in store for latecomer countries; third, will China continue to catch-up?

Ad (1): Can other countries, India comes to mind easily, be the next disruptors after China? To start with, most likely countries like India will develop more gradually. China-style "behind-the-wall" industrial policies will not be as effective and available because of domestic and multilateral (WTO) policy constraints. Second, the hope for relocations of tasks from China to 
neighboring cheaper production locations may not materialize as tasks in China may be robotized rather than offshored. In a similar vein, as discussed before, robotization has the potential to substitute for offshoring and eventually even leading to reshoring. Hence, the China model may no longer be a blueprint for other latecomers. Rather, developing market size (also through regional trading agreements) may be a more promising means to gain from relocations amongst neighboring countries. For example, for Chinese companies it may be more appealing to relocate production to Africa than to neighbors because of Africa's closeness to Europe and its preferential access to the EU market.

Ad (2): New technologies, especially those that are boosted by reduced faceto-face communication costs like, tele-presence and tele-robotics as argued by Baldwin (2016). These new disruptive technologies may allow workers in emerging economies to performs service tasks, like surgery, steering robots, online consulting using VR and AR technologies, etc. Hence, remote and landlocked countries that have not benefited from inclusion in GVCs in the past 30 years, may soon discover new comparative advantage in virtual tasks. Therefore the "great convergence" may go on with disruptive changes in the service sectors of advanced economies.

Figure 4. Trade in goods and services as a share of GDP (in \%) for selected regions 1960-2016

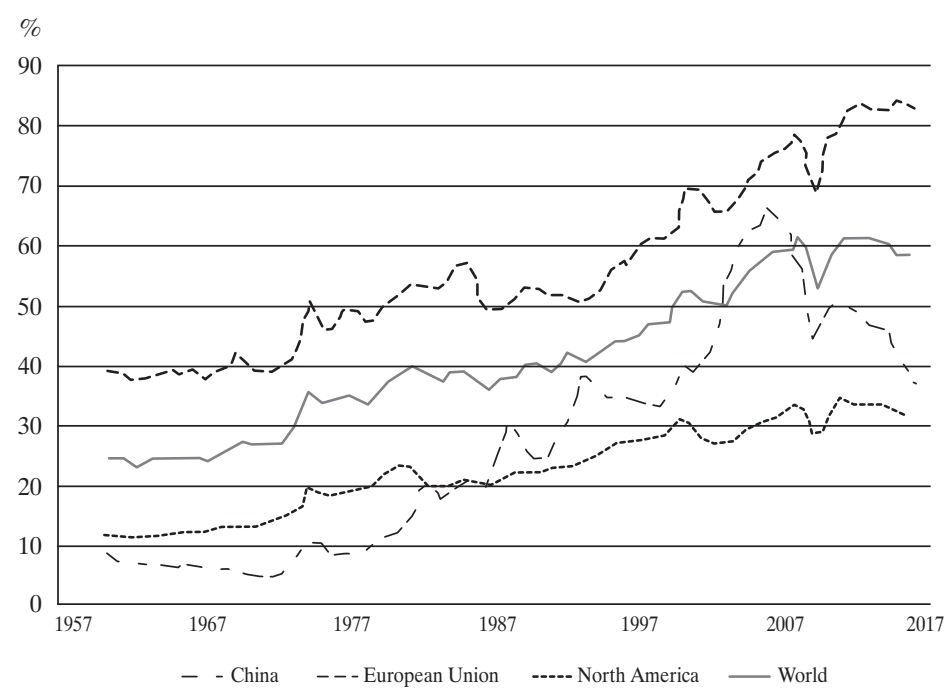

Data Source: World Bank (http://data.worldbank.org). Retrieved August 9, 2017.

Ad (3): What about China? If we look at trade integration at the regional level (Figure 4), we can observe that trade integration shows its highest 
dynamics in Asia, and here in particular in China within the first decade of the $21^{\text {st }}$ century, largely because of China's extreme participation in GVCs. As can clearly be seen, China is now disintegrating - at least relative to GDP. This has to do with three major developments: (1) the increasing importance of the Chinese domestic market, (2) a "moving-up-the-ladder" that allows to perform tasks now within China rather than relying on imported intermediate inputs and hence reshoring into China, as discussed in section 2.2, and (3) the deliberate "Made in China 2025" strategy of the Chinese government.

Moreover, China places a high emphasis on achieving technological leadership in renewable energies and other environmental-friendly technologies and products like, e.g. electric cars. And, last but not least, China state-led approach to digital technologies may give its digital industry a competitive edge, especially when it comes to AI where the sheer size of available and usable data is key to its development.

\subsection{Global Finance After the Global Financial Crisis}

At a first glance, the empirical evidence points to a global retrenchment of international finance. A closer look reveals two major changes: First, retrenchment in global banking is predominantly a European affair, and second, amongst other cross-border financial activities, FDI was the only asset category that increased relative to GDP after the GFC. However, it did so with a remarkable concentration on so-called financial centers.

To start with global banking, it must be noted that retrenchment is predominately driven by European banks. Persisting aftershock-effects of the Euro crisis, a still unhealthy banking system and a not fully fixed Eurozone architecture, especially the lack of a European deposit insurance scheme (EDIS) and limited fiscal burden sharing, has contributed to a general deleveraging of European banks, especially in global banking.

To fully understand the structural changes in global banking, it is important to distinguish two forms of banking globalization: the international business model of cross-border lending and depositing, and international model of establishing foreign affiliates by FDI (McCauley, 2011). After the GFC it was predominantly the international model that contracted, thus shifting global banking towards multinational banking. This implies that there is actually more "consolidated" exposition to foreign risks than suggested by balance-of-payments positions. ${ }^{4}$

4 The BIS reports global banking statistics on a consolidated and locational base. The consolidated statistics classify banks by nationality whereas the locational statistics classify banks by residence, similar to balance-of-payments statistics. 
Based on data from the Bank of International Settlements consolidated banking statistics (measured based on nationality of banks), McCauley et al. (2017) find that for the period 2007-2016 retrenchment was severe in the combined Euro Area plus UK and Swiss, with the notable exception of Spanish banks. US banks largely kept their international activities at the same level as before the crisis, but shifted more towards the multinational banking model and increasing the exposure slightly. McCauley et al. (2017, p. 8) therefore conclude: "Banks from the rest of the world, however, continued down the path of international financial integration ... Japanese, US, Canadian, Australian and emerging market banks expanded their foreign claims around the world, partly substituting for the retreat of European banks. In that sense, the trend towards deglobalisation is not broad-based." It should be noted that the rise of emerging economies in global banking is likely to be underestimated because many emerging economies do not report to the BIS, or have started to do that only recently, like China. However, first analyses show that emerging economy banks are rapidly integrating into global banking markets, especially Chinese banks.

Coming to cross-border direct investments, the resilience of FDI to financial crises is not entirely surprising. It is well documented that in the aftermath of a financial crisis, FDI is a much more stable source of foreign finance than bank or portfolio flows. This is not the least so because financial crises often go together with a currency crises and large devaluations increase the price competitiveness of the crisis economy. However, in a global financial crisis this narrative may not be sufficient. Lane and Milesi-Ferretti (2016) have provided an in-depth investigation of post-crisis financial integration trends and found an over-proportional role of "financial centers" in FDI, a role that increased further after the GFC. A large share of the post-crisis increase in FDI can be explained by an increase in the FDI positions of and in these jurisdictions.

Who are these "financial centers" and what kind of FDI are we talking about? Lane and Milesi-Ferretti select financial centers on the basis of their extraordinarily high ratios of external assets and liabilities to GDP, compared to the rest of the world. Next to the well-known small financial centers (such as Bermuda or the Cayman Islands), several advanced economies are also classified in this category, notably Belgium, Hong Kong, Ireland, Luxemburg, Netherlands, Singapore, Switzerland and the United Kingdom. In the aftermath of the GFC, this country group experienced a sharp contractions of cross-border banking activities, while at the same time FDI claims and liabilities increased drastically. What are the main drivers of these FDI dynamics?

To start with, the larger countries in this group are home of big multinational companies. Hence, when FDI activity increases in general, their FDI increases 
too. But this is not enough to explain both the concentration in and the huge shift of FDI towards financial centers. Lane and Milesi-Ferretti (2017, p. 14) report: "As of end-2007, residents of financial centers held some 43 percent of the world's FDI claims abroad, and FDI in financial centers accounted for around 40 percent of the global total. By end-2014, FDI claims by financial centers had risen to half of the world total, and liabilities to 44 percent." They then identify two major factors explaining the size and the recent dynamics of financial center's FDI positions.

First, the authors point to the growing importance of so-called "special purpose entities", i.e. legal entities created by parent enterprises located in other jurisdictions. The purpose of such entities is not to perform production activities. Rather, they are created to raise capital or hold assets and/or liabilities. While data on such entities are not widely available, it is documented that more than $75 \%$ of all FDI claims and liabilities in the Netherlands are related to such entities. For Luxembourg, the corresponding number even exceeds $90 \%$.

Second, the authors report an increased tendency of MNEs to move their domicile to a financial center. If only the headquarter is moved but not the production facilities, the latter will add to the FDI stocks of the financial center. Well-known tax havens like Ireland were thereby able to increase reported FDI claims by $\$ 600$ billion between 2007 and 2014, bringing FDI claims to a level that exceeds the Irish GDP by more than a factor of 5.5

In sum, post-GFC global finance is characterized by (1) the weakness of European banking, (2) a shift towards multinational banking, (3) an increasing globalization of emerging economy banks especially China, and (4) a shift of FDI towards financial centers for other reasons than production, suggesting that an "increased complexity of the corporate structure of large multinational corporations is playing an important role" (Lane and Milesi-Ferretti, 2017, 5).

\section{Globalization and the Populist Backlash}

Europe and the USA are both experiencing a wave of populism, which, especially in the case of the USA, has brought old-style protectionism back on the policy agenda, thus threatening the multilateral approaches to globalization that has ruled post-war international relationships. For our topic the core issue

Lane and Milesi-Ferretti (2017) remind us that in the case that the shareholders of the re-domiciled MNE remain the same, portfolio equity liabilities would increase by the same amount, thus leaving the capital account balance unchanged. 
is to what degree the rise in populism can be traced backed to economic shocks transmitted through globalization?

In a recent historical study, Eichengreen (2018) conjectures: "The history recounted here suggests that populism is activated by the combination of economic insecurity, threats to national identity, and an unresponsive political system, but that it can be quelled by economic and political reforms that address the concerns of the disaffected." He goes on defining populism as a political movement with anti-elite, authoritarian, and nativist tendencies. Hence, his definition accommodates both left-wing populism, which emphasizes the antelite element, and right-wing populism that tends to blame the "others" for their grievances.

When it comes to the recent rise of populism, two intellectual camps are swift identifying the sources: the one camp highlights the role of the economy, especially the rise of economic insecurity with globalization and especially after the GFC, the other camp argues in favor of a "cultural backlash". Eichengreen's historical account allows for a combination of both, but also emphasizes responsibility of an "unresponsive political system".

To work out the role of globalization for the rise of populism, I will first look on the distributional impact of globalization, continue then by discussing the recent (un-) responsiveness of political systems, before finally reviewing the globalization-populism nexus.

\subsection{Globalization and its Discontents}

Globalization, and especially the China shock, has both positive and negative aspects. Next to the usual gains from trade - namely lower prices for product using relatively cheaper resources from abroad - participation in GVCs can have a positive impact on labor productivity, thus increasing the international competitiveness of domestic firms. According to Constantinescu et al. (2017), a $10 \%$ increase in GVC participation increases average labor productivity by $1.7 \%$.

However, increased globalization of value chains also requires massive restructuring in advanced countries and hardship for those who lost their jobs due to the offshoring of tasks. It is now well-documented that global income distribution has changed dramatically from the 1990s onward. The evidence points to two major disruptions in distribution: first, severe redistribution effects across and within countries by income strata. Second, a pronounced fall in the share of labor income relative to the share of income going to capital. 
Redistribution effects are now famously visualized by the "Elephant Curve" (Lakner and Milavonic, 2013). The curve illustrates the growth of per-capita income by percentiles of the global income distribution from the poorest $5 \%$ on the left to the richest $1 \%$ on the right. Over the 1988-2008 period, percapita income grew on average by about $24 \%$ (or $1.1 \%$ p.a.). While the poorest $5 \%$ were clearly not fully benefitting from this growth, the middle-income strata in emerging economies did, thus lifting many people out of poverty. Inequality across countries has decreased - a process that Baldwin (2016) has called "the great convergence". For advanced countries the key concern are the developments in the upper 20\% percentile: The "trunk of the elephant" shows almost stagnating per-capita incomes for the 80-90 percentile group and the underperformance of almost everyone except the upper $1 \%$. This is often read as evidence for the decline of the rich-countries' middle class while a very small elite is experiencing exorbitant income growth. Given that all this occurred at the same time when globalization rocketed, the link between the loss of well-paid (manufacturing) jobs in the rich countries due to competition from emerging economies is readily made.

However, coincidence with hyper-globalization and the rise in GVCs it not causation. As discussed before, new technologies and the emergence of digital superstar firms bear considerable responsibility for job and income losses, especially amongst less-skilled workers in advanced countries. A recent study (IMF, 2017) investigates the causes of the widespread fall of labor shares in income. It reports that in advanced countries the income share of labor has fallen by close to four percentage points between 1993-2014. About half of this fall is attributed to technological advancement, while GVC participation as well as financial integration played a much smaller role. ${ }^{6}$ The study has also decomposed the impact according to skill levels. This reveals strong redistribution effects across skill groups: high-skilled gain and low-skilled lose more than medium skilled. While these changes can only be attributed to a small amount to technology or GVC participation in the case of high and low skilled, this is not the case for medium-skilled workers. They lost a large part of their income share due to technological advances and GVC participation. However, in advanced countries, technology was an even more important factor in "hollowing-out the middle class". According to the earlier mentioned study by Acemoglu and Restrepo

6 By contrast, in emerging markets, participation in GVCs account for the lion share in the almost 6 percentage point reduction of the labor share, while technology as such played a minor role. One should, however, note that we are talking here about income shares and not absolute income. As income has been growing rapidly in several emerging countries, in particular in China, labor incomes are still rising, only not as much as capital income. 
(2018) this result can easily be reconciled with the effects of automating tasks, hence also pointing to the important role of robotization.

From this evidence one can conclude that the distribution of the gains from globalization to workers in the industrial world has become increasingly biased towards the highly skilled. Moreover, as capital shares increased, global corporation gained tremendously.

The situation has been aggravated after the GFC has pushed especially the advanced countries into a long-lasting recession in the US and in Europe. In Europe, and especially in the Eurozone, the situation has been deteriorated further by the subsequent Eurozone crisis. Whereas in a high-pressure economy the fallout of structural change can much easier be cushioned by increasing employment opportunities, the twin shocks of globalization and financial crises easily results into deep and permanent effects on income and economic security for many people.

In sum, we identified three major economic drivers of economic insecurity: GVC participation and relocation of jobs; technology and the robotization/ digitalization of jobs; and financial crises.

\subsection{The Responsiveness of Political Systems}

If history is a guidance, populism should be expected to be propelled by an "unresponsive" political system (Eichengreen, 2018) or, to put it in positive terms, populism can be contained by timely and adequate policy responses. What holds back such responses?

First, the classical argument of economists that losers from globalization can be compensated from overall gains of trade is true in principle, but unfortunately only as a theoretical option. In the practice of the past decades, global corporations were quick in using the tax-avoidance possibilities that a globalized world of investment offers, and winners of globalization successfully voted and lobbied for tax reductions rather than in favor of redistribution to bring the disfavored back into rewarding work. At the same time, the financial crisis shocks and subsequent great recession has reduces the re-employment chances of losers from globalization drastically.

Secondly, policy responses are a matter of political choice. Clearly, some cultures are less inclined to cushion structural change by social and employment policy than others. Just think of the US versus Europe, and here especially of Scandinavian countries with their generous welfare systems.

Thirdly, adequate policy responses can also be limited by available resources relative to the size of an idiosyncratic economic shock. A globalization shock 
can be so big that the means to "compensate losers" may be restricted by tax revenues, e.g. by foregone tax revenues because of tax avoidance strategies by MNEs. Alternatively, the financial crisis shocks can be so dramatic, like the GFC, that even massive policy interventions are not sufficient to avoid a deep and long-lasting recession.

Fourthly, certain institutional frameworks, such as fiscal rules limiting fiscal deficits can constitute a "policy strait jacket". This is clearly the case for the Eurozone. Within the European Monetary Union (EMU) countries can neither respond with a national monetary policy nor with a currency devaluation to an idiosyncratic shock. ${ }^{7}$ Moreover, fiscal policy in many member countries was seriously constrained by the fiscal rules of the European Stability and Growth Pact.

Finally, ideology and lack of international solidarity can also play a role. In the Eurozone, policy makers largely relied on labor market liberalization to absorb globalization and financial crisis shocks. During the Eurozone crisis, the lack of cross-border fiscal transfer mechanisms, and the unwillingness of creditor countries to accept sufficient burden-sharing across borders, has biased the bail-out packages towards a combination of austerity policy with structural reforms to induce downward wage and price adjustments. Most academic observers agree, that this policy response has seriously deepened and prolonged the crisis in many, especially southern European crisis countries.

\subsection{Globalization, Financial Crises, and the Rise of Populism}

Taking this all together, we can document increasing economic insecurity in many advanced countries, predominantly amongst the low-skilled but increasingly also threatening the middle class. However, it is difficult to single out one, or at least, the main culprit. Faced with a complex threat to their standard of living and economic security in the presence of an unresponsive policy, scapegoats are easily identified. Depending on the ideological, educational and cultural background of people, the culprits identified by right-wing populists are typically "the others" - immigration, foreign competition, etc., while left-wing populists tend to blame the "elites". Clearly, populist "political entrepreneurs" reduce the complexity of the world to offer under-complex recipes to the woes of the disenchanted.

7 As the financial crisis of 2008 was a common shock to all member countries this argument was of less relevance (though the adequacy of the monetary policy reaction of the ECB at that time is debated) than during the Euro crisis starting in 2010, which hit member asymmetrically. 
While some evidence points to the cultural hypothesis, especially when it comes to the decision left versus right populism, most recent in-depth research work identifies increased perceived and realized economic insecurity as the major source of populism. In a European-focused study, Guiso et al. (2018) investigate how the vote shares of populist parties in different European regions respond to (1) a "globalization shock" (i.e. the "China effect") and (2) to the European financial crisis of 2008-2013. Europe offers a natural experimental setting to identify the sources of populism, because the "China shock" has had a different effect on Western Europe than on Eastern Europe. In Western Europe off-shoring of tasks/jobs was frequent, whereas Eastern Europe was also a recipient of offshored tasks and jobs from Western Europe. On the other hand, the Eurozone member countries experienced a tight policy strait-jacket (dependent on the countries relative economic and fiscal position at the arrival of idiosyncratic shocks) that non-member countries did not face.

Guiso et al. (2018) use this setting to show that the globalization shock to Eastern European regions, which are most exposed to globalization, has a negative effect on populist votes, whereas in Western Europe the globalization shock has boosted votes for populist parties. This evidence suggests that winners and losers of globalization are an important factor behind populist voting. Moreover, the authors also show that in Western Europe countries, which are member of the Eurozone, the strait-jacket effect explains three quarters of the higher share of populist parties as compared to the non-Eurozone countries. In other words, the lower the discretion of countries to deal with globalization and financial crisis shocks, the higher the support for populist parties. Hence, Guiso et al. (2018, p. 4-5) argue that " The cultural backlash against globalization, traditional politics and institutions, immigration and automation cannot be an exogenous occurrence, it is driven by economic woes."

In a similar vein, in a historical study of the impact of financial crisis on voting behavior and extremist, politics covering the period 1870-2014, Funke et al. (2015) show that recessions induced by financial crises increase the vote share of far-right parties on average by $30 \%$. They were, however, unable to identify a similar effect in normal recessions or after other macroeconomic shocks. The authors therefore posit that financial crises are more likely be perceived as the result of policy failures than "normal" crises, hence traditional policy elites can easily be blamed. Moreover, they point to the fact that resolving financial crises often requires unpopular bailouts, which are seen as rewarding those responsible for the crisis in the first place. And finally, the social repercussions of financial crisis typically go deeper and are lasting longer than normal crisis. 
In sum, unaddressed societal ruptures, increased insecurity as a consequence of globalization and financial crisis shocks, instable and thus crisis-prone global, regional and financial system, while at the same time the fortunes of the top $1 \%$ and corporate tax avoidance are part and parcel of the daily news, this constitutes the soil on which populists can easily grow their authoritarian, simplistic recipes and blame scapegoats rather than addressing the real issues at stake.

\section{European Policy Options in the New Global Economy}

The implications of the new incarnation of globalization and the policy responses to it will surely shape the future of Europe. The lesson from the discussion above reveals that globalization is not sustainable in itself. Rather, without "managing" globalization and its distributional consequences, globalization tends to undermine its own foundation: the faith in open markets, societies and borders.

For Europe, open markets both within the EU as well as towards the rest of the world, are vital for its economic success model. Hence, Europe has a deep self-interest in making globalization sustainable. To contribute to it, there are many areas that require something ranging from attention to severe policy actions. The potential "to-do-list" is long and can be found on the websites of numerous initiatives, think tanks, and EU directorates. It is coalescing around the topics of digitalization, populism, inequality, competitiveness and so forth. But next to drawing up to-do-lists, the potential policy responses pose an assignment challenge: At what level should they be addressed: at the national, the European level, or at the global level? In what follows, I will first comment on the "laundry list" of the most pressing policy areas, before addressing the issue of the governance.

\subsection{Areas of Policy Responses}

In a speech at the 2017 Economic Policy Symposium of the Federal Reserve Bank of Kansas City in Jackson Hole, ECB president Mario Draghi argues: "People are concerned about whether openness is fair, whether it is safe and whether it is equitable." 
Starting with the issue of equity it is a commonplace amongst trade economist that opening up to trade creates winner and losers within a society. Since there is a strong case for net benefits from trade, economists prefer compensation of losers over protectionism. The trouble with compensation is, that more often than not it is not sufficient or even does not take place at all. Addressing the distributional consequences can be done by compensating the losers through its welfare system, by re-distribution though the national tax systems, and by re-training.

With the proliferation of GVCs, it became evident that competition is not anymore about goods between firms across countries but between individual workers on a global market place for tasks (Baldwin, 2006). The offshoring of tasks can happen at any time. "Suddenness" and "unpredictability" are the main features of fragmentated global production. Additionally, the emerging robotization of tasks, and their subsequent off- and reshoring will alter the required skills drastically towards team capabilities, digital literacy, adaptability, flexibility, and the ability to learn-to-learn. Moreover, the advent of face-to-face digital communication will increasingly make high-skilled jobs vulnerable, too.

Old-style protectionism of industries can therefore not be a successful instrument to cope with digitalization and the new globalization. Instead, focusing on education, learning to learn, and adaptability is the response of choice. The key to successful (re-) distribution policy today is not anymore to protect industries but to protect people (Baldwin, 2006). Moreover, because digitalization and globalization has contributed to reduce the share of global income going to labor, and thus to increased inequality within many countries, addressing inequality beyond protection of losers of globalization has become a pressing political issue, too.

However, as the above discussion has revealed, the impact of globalization on equity is often indistinguishable from the impact of technology: it does not make a difference whether your job will be taken over by a robot or by workers abroad. In both cases this involves job and temporary or even permanent income losses. What separates trade from other structural changes is the issue of fairness. Rodrik (2017) has argued that redistribution policies alone are not satisfactory to deal with the challenges of globalization: "That brings us to a different social and political objection to trade - that trade violates norms embodied in our institutional arrangements. The suggestion here is that trade may undercut the social bargains struck within a nation and embedded in its laws and regulations. ...Trade is not merely a market relationship, but an intervention into domestic institutions and an instrument 
for reconfiguring them to the detriment of certain groups." As a consequence, Rodrik finds it justified to respond to "social dumping", for example when foreign competitors undercut wages by means of abusing workers' rights (political wage suppression, forced labor, etc.) in a similar way as nations respond to general "price dumping". His idea is basically to protect the national social compacts via national anti-dumping policies rather than by a multilateral response.

In contrast, Mario Draghi (2017) has argued in favor of a multinational approach to address fairness (and safety) issues: “...multilateral cooperation, leading to regulatory convergence, is a precondition for addressing the underlying causes of these concerns. To demonstrate this, let me draw on our experience of managing openness within the European Union. As regards fairness, the point is obvious: regulatory convergence provides the strongest assurance that the playing field is level right across the European market. This is why, as borders have opened within Europe, common supranational powers of legislation and enforcement have strengthened in parallel. Similarly, what has permitted the Single Market to survive various financial and consumer protection crises is its ability to restore safety by adapting market-wide regulation and enforcement."

However, European regulatory convergence is not only an attractive instrument to create a fair and level European playing field. Witness the recent experience with the European "General Data Protection Regulation (GDPR). The Economist (22nd September 2018, p. 13) argues that "the principles of the GDPR are now being used as a benchmark for good data practice in markets well beyond Europe". With its huge single market, the EU can use its regulatory competence to not only make Europeanization but also globalization fairer in the eyes of their citizen. Given the new realities of the global economy, the key areas for effectively influencing or at least contributing to global regulatory best-practices are clearly in the areas of tax avoidance, race-to-the-bottom tax competition, labor rights, financial stability, and other multilateral initiatives towards regulating global finance, trade, investment, know-how, and data exchange. A Europe that firmly addresses these issues within the EU and beyond, thus setting a global agenda on addressing fairness in a multilateral setting, can contribute significantly to make globalization not only fair, safe and equitable, but also sustainable.

A Europe that puts people first with respect to equity and addresses the fairness issue seriously within Europe and at the multilateral level by highlighting the core issues that concern people, will produce visible results that will surely appreciated by European electorates. 


\subsection{European Governance}

\subsubsection{The European Policy Trilemma}

At what level should decisions be made? What should remain at the level of the nation state and what should be delegated to a supranational level, be it to the European Union, or to a global, multilateral institution like the WTO? Rodrik (2011) has argued that there is a "globalization trilemma" that forces policy makers to make choices between hyper-globalization, national decisionmaking and democratic politics (see Figure 5).

Figure 5. Rodrik's Globalization Trilemma: Pick 2, only 2

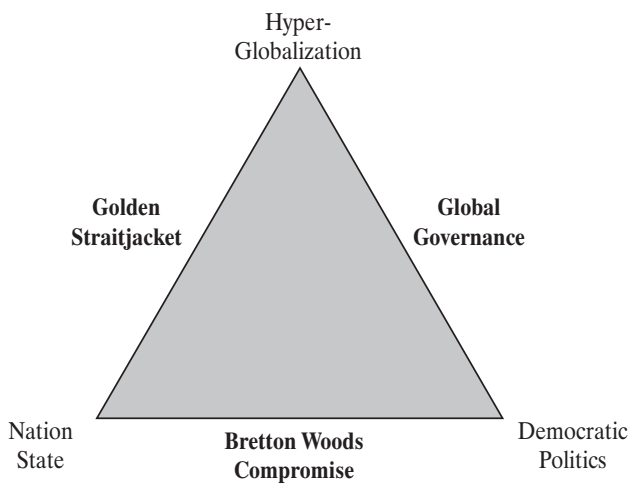

Source: Graph based on Rodrik 2011: 201.

The basic argument is that excessive globalization needs democratically legitimized global governance. Alternatively, if countries are not willing to share sovereignty with supranational institutions, they will lose democratic control in the presence of hyper-globalization. In practice they are then at the mercy of market "mechanisms". For example, the gold standard enforced automatic adjustments, if needed. The experience in the early 20th century with automatic (deflationary) adjustments was disastrous as the then young democracies and an increasingly powerful labor movement were unwilling to accept exorbitant unemployment levels as a devise to induce wage deflation. Likewise, the reliance of wage and price deflation to restore competitiveness in several countries during the Eurozone crisis has created mass employment and severely threatened the social fabric in the affected countries. Alternatively, the trilemma suggests that democratic decision-making at the level of the nation state requires to restrict hyper-globalization. 
But is the European Union, which explicitly deals with harmonizing standards across the EU, not better equipped to deal with these issues with respect to European economic integration? Benoit Cœuré (2017), Member of the Executive Board of the European Central Bank (ECB), relating to Rodrik's trilemma, argues: “... the European experience shows that these trade-offs are manageable. A variant of globalisation could be based on a parsimonious framework of international rules which leaves room for manoeuvre for national governments. In fact, the principle of subsidiarity which is firmly anchored in the Treaty on European Union can be interpreted as a regional attempt to solve Rodrik's 'political trilemma'. It aims to ensure that decisions are taken as closely as possible to the citizen and that action at European level is only taken if the objectives cannot be properly achieved at national, regional or local level”.

What follows from this discussion, is that two major issues need to be addressed: First, Rodrik's trilemma might be present in some, but not all aspects of "globalization" alike. Hence, it is important to identify, which decisions are best taken at what level, depending on the issues at stake. Second, all decisions delegated to a supranational level requires some form of democratic legitimization.

\subsubsection{Rebalancing Policy Areas in Europe}

The optimal allocation of policy areas is nothing new, and a theoretical foundation can be found in standard textbooks on European integration, such as Baldwin and Wyplosz (2012) under the heading of "theory of fiscal federalism". According to that theory one should allocate decisions to the supranational level only when the benefits of doing so exceed the cost of giving-up sovereignty. Otherwise decisions are best taken at the national or even local level. In fact, allocating decision-making to the lowest level possible without giving-up net benefits is the core of the principal of subsidiarity. The major benefits of supranational regulation are rooted in scale economies and spillovers, but they have to be balanced with national preferences, which constitute the "costs". Yet, the devil is in the detail.

Starting with the issue of equity it is clear that it is predominantly the task of nation states to address distributional issues to stabilize the social fabric of a country. The national preferences regarding redistribution and the institutions of national social systems still differ widely within the EU, and it is unlikely that both will converge soon sufficiently enough to make a European approach superior. However, allocating redistribution to the nation states comes with 
three major caveats. First, structural change causes much less distress in an employment-friendly macro-economic environment, which is often beyond the full control of national government. Especially in the Eurozone, the almost (non-)existence of fiscal transfer mechanism and the coordination of macro and macro-prudential policies are important issues that need to be addressed. Secondly, trade agreements are negotiated at the EU level, but have often differential impacts on the various member countries, which calls for some kind of a transfer mechanism. ${ }^{8}$ And third, tax-avoidance strategies both within Europe and globally, which limit the resources available for redistribution, can effectively only be addressed at a supranational level.

A clear case for the superiority of European governance is the European single market, which exhibits strong scale economies. Of course, national preferences militate at times against EU product norms etc., but by-and-large the benefits grossly outweigh the costs of giving-up sovereignty. However, the cost-benefit balance is not carved in stone. For example, especially in the times of economic stress after the GFC, the "free movement of people" principle of the single market has caused disruptions and is viewed as at least partly having influenced the British Brexit vote. Hence, the EU-UK Brexit negotiations are gyrating around the (im-)possibility of getting single market access minus the "free movement of people" part, something that the EU commission strongly opposes at the time of writing.

By contrast, joint foreign policy, defense policy, migration policy and external border control, have tremendous benefits, but national preference have diverged so dramatically in the past that these areas have largely remained under national control. However, the rapidly changing geo-strategic situation is increasingly tipping the balance towards European governance in some if not all of these areas.

There are, however, key areas in which a rebalancing of governance is necessary. Most importantly, this is true with respect to the European Monetary Union (EMU). It is now broadly acknowledged that EMU as designed by the Maastricht Treaty of 1992 is a seriously flawed currency union. Basically, it created a monetary union without a banking union and without any fiscal transfer mechanisms. However, to cope with asymmetric shocks within a monetary union, it is required to have sufficient risk sharing mechanisms. In terms of Rodrik's

8 The EU has established the European Globalization Adjustment Fund (EGF) in 2007 to co-finance the reintegration of workers negatively affected by globalization. The EGF is, however, capped to a meagre amount of approximately $0.1 \%$ of the EU budget. Moreover, more than $50 \%$ of the funding has been used for dealing with the macroeconomic fallout of the financial crisis. For a detailed analysis see Claeys and Sapir (2018). 
trilemma this means that giving-up sovereignty in some policy areas is necessary to make the EMU sustainable (Sander, 2011). What is ultimately needed is subject to controversy, but there is an increasing consensus that next to some kind of fiscal risk sharing (e.g. via the European Stability Mechanism - ESM), completing the European banking union by introducing a European deposit insurance system (EDIS) is key (see e.g. Bénassy-Quéré et al., 2018). ${ }^{9}$ In other areas, especially with respect to the "fiscal strait-jacket" of the European Stability and Growth Pact, it has been argued that it may be advisable to "renationalize" fiscal policy to "give back control" (and - one must add -responsibility) to national governments over the use of their tax income (Eichengreen and Wyplosz, 2016). ${ }^{10}$ In fact, this is what they have been elected for and for what they are accountable to their voters. In other words, the governance of the Eurozone needs rebalancing, not only to make EMU sustainable, but also to cope with the rising anti-European populism (Sander, 2016).

Finally, a new and emerging major task at the European level and beyond is the dealing with global digitalization and superstar firms. There are two major areas of joint action.

First, a joint European industrial policy strategy is fundamental. UNCTAD (2018, p. 128) reports: "In the decade since the global financial crisis, the number of countries adopting national industrial development strategies has increased dramatically. ... Countries at all levels of development are using targeted industrial policies, not only for economic development purposes, but also to respond to myriad contemporary challenges, such as creating jobs and reducing poverty, participating in the technological revolution and in global value chains (GVCs), promoting efficient and clean energy and greening the economy." While those policies are often devised at the national level, at least two arguments speak for the superiority of a bold European strategy: On the one hand, globalization and digitalization have shown uneven effects within the European single market, especially to the detriment of several southern European countries that should therefore be addressed by joint initiatives. On the other hand, superstar firms are global in reach but deeply rooted in their home country, suggesting that national conditions in terms of market size, supporting industries and resources, as well as policy incentives are important to nurture such industries. The European single market is therefore key, but also

9 However, national sentiments occasionally militate against regulations that deliver net benefits, as the current debate over the EDIS reveals. Especially German preferences against the perceived risks of debt "mutualization" are currently seriously impeding the project.

10 Eichengreen and Wyplosz (2016) argue that renationalization of fiscal policy requires to address the problem of debt overhangs as well as establishing credible no-bailout rules. 
need to be complemented by a digital single market and activities in the area of knowledge and expertise, like e.g. the European Universities Initiative. While these initiatives already exist, the key is their sheer size and the willingness to transfer resources across borders to make such efforts effective.

Second, and as argued before, European regulation can be used to set or at least influence global standards in the currently highly unregulated digital markets, which ultimately can help Europe to establish and/or foster competitive advantages in digital industries.

\subsubsection{Towards a Better Democratic Legitimization of European Governance}

This brings us to the problem of democratic legitimization of decisionmaking at the supranational level. Here, the most serious problem is that most decisions are taken at an inter-governmental level, typically based on proposals prepared by the European Commission. The European parliament has some, but limited say depending on the issue. Thus, democratic legitimization comes predominantly indirectly from national elections. For national voters it is therefore often difficult to trace the decisions taken back to their voting casted at the national ballots. Does Europe therefore need a major reform of its structure and decision-making rules in the face of the new global economy?

Especially the rise in anti-European sentiments and populism within the EU makes a "business-as-usual" strategy with only some gradual adjustment a dangerous strategy. Obviously, this is seen by the EU commission too. In a White Paper on the Future of Europe (European Commission, 2017), the commission contrasts five scenarios: (1) "carrying on", meaning incremental progress towards "an ever closer union"; (2) a "focus on the single market", thus reacting passively to the differences in preferences; (3) "those who want to do more", i.e. allow for a multi-speed Europe towards the destiny of an ever-closer union; (4) focusing on selected policy areas and "doing things more efficiently", i.e. a new prioritizing, eventually after a detailed reconsideration of cost and benefits; (5) "doing more together", i.e. moving faster to a closer union. It is beyond the scope of this paper to contribute to an analysis of a rebalanced Europe in the light of these five scenarios. Nevertheless, three points will be made in the light of the discussed dual challenges of globalization and digitalization.

First, there are numerous obvious areas where benefits are overwhelming from a purely economic point of view: the single market, including open internal borders to allow European value chains to stay competitive; 11 a European digital

11 I have not listed issues like migration, security and foreign policy here because they are beyond the scope of the paper. However, to allow a borderless Schengen area to function 
strategy, using the leverage of the single market to reach out with regulation beyond Europe; addressing tax avoidance; promoting rules to ensure financial stability; creating a European knowledge space; joint infrastructure investment in transport and communication, and so forth.

Second, the advantages of cooperation are less obvious in other areas, particularly with respect EMU and it is indeed questionable whether the "finalité" of the Maastricht treaty in this respect is still justified. This brings us to the issue of an ever-close-union versus a two or multi-speed Europe or a multitrack Europe. In the first case all countries are obliged head towards more integration in all areas (finalité). De facto, however, this is an illusion as some but not all member countries have (yet) joined EMU or the Schengen area. One might view Europe therefore as a two-speed union in which the EMU countries constitute the fast-integrating core, while the rest follows behind. This again, however, masks that not all EMU countries are ready or willing for fast track. Hence, in reality the EU is already at best a multi-speed Europe. Moreover, several countries simply do not share the finalite vision, i.e. prefer staying out EMU or Schengen. In this respect, it would be better to speak of a multitrack Europe. The problem with multi-track is the danger of raisin picking. But this danger has to be weighed against increasing sentiments against a too intrusive Europe governance, especially in the new member states. However, the attractiveness of participation in more or all fields of European integration under a multi-track regime crucially depends on the "output legitimacy". As shown above, there are many areas in which joint European policy actions allow to deal much better with globalization than relying on purely national policies in a world of superstar firms and rising new superpowers like China. If Europe "delivers", multi-track must not be a threat to European integration but could instead promote integration wherever constructive and advantageous.

Third, and finally, "input legitimacy" is crucial. The debate about a democratic legitimation of European decision-making is complex and revolves around strengthening the European parliament. There are many proposals out and it is beyond the scope of this paper to do full justice to all of them. But it should be noted that the reform proposals depend crucially on taking a stance regarding single versus multi-speed versus multi-track. For example, a team around the French economist Thomas Piketty, a pro-European, recommends to strengthen the powers of the European parliament as well as creating a "Eurozone Assembly" (Hennette et al., 2017). Eichengreen (2018) has criticized this approach as at best a partial solution, as it relies - in his view

smoothly, this may require more joint external border control. This argument is therefore here based on purely economic grounds. 
- on an antiquated vision of a two-tier Europe with the Eurozone at the core. He goes on suggesting to empower the existing European parliament along the lines member states participate in the various areas of European institutions and policies in a multi-track Europe. For example, members of parliament from Euro area countries vote on Euro affairs, representative from Schengen countries on Schengen-related matters and so on. This way, Eichengreen (2018) hopes that " $[T]$ he Parliament would channel the voice of the people, rendering the technocrats of the Commission, the ECB, and other EU institutions democratically accountable, but only the voice of the relevant people-citizens of those countries that agreed to cede national prerogatives on the issue in question." And, as he adds at the end of his book, this could eventually even help containing the rise of anti-European populism on the continent.

\section{Conclusions}

Europe is facing a triple challenge from globalization, digitalization, and rising anti-European sentiments within the union and increasing populism elsewhere. What makes these challenges so difficult to deal with is that they are deeply intertwined. New technologies have been driving globalization in the past and will continue to do so, though with a changing character. Their associated and politically not sufficiently addressed socio-economic consequences have increased economic insecurity in many countries of Europe and made deep inroads into the middle-class.

However, in many cases a united Europe is better equipped to deal with globalization and global superstar firms than small nation states. Most of all, it can use its huge single market to contribute to the setting of a global agenda that puts people first in global economic affairs by promoting better global rules for digital business, labor rights, financial stability, cross-border investments and knowledge flows, and so forth.

This, however, requires a strong, functional, and better democratically legitimized European Union. The Jean Monnet dictum " $L$ 'Europe se fera dans les crises et elle sera la somme des solutions apportées à ces crises" [Europe will be forged in crises, and will be the sum of the solutions adopted for those crises] may have worked in the past. In a globalized and digital world without a benign hegemon and guarantor of a rules-based world economy, Europe has to take up its new role as one of three superpowers. Only if Europe will go for 
a big push forward, it will be able to contribute effectively to the future of the global economy.

Europe needs to wake up and become pro-active in three aspects: increasing the legitimization of its policies by democratization, deliver in terms of wealth, prosperity and stability, and take-up global responsibility for a world economy to make the new global economy a better place to work and live in.

\section{References}

Acemoglu, D. and Restrepo, P. (2018). Modeling automation. American Economic Review Papers and Proceedings, 108, 48-53.

Autor, D., Dorn, D., Katz, L.F., Patterson, C. and Van Reenen, J. (2018). The fall of the labor share and the rise of superstar firms. MIT mimeo updated from NBER Working Paper.

Baldwin, R. (2006). Globalization: The great unbundling(s). Prime Minister's Office: Economic Council of Finland. Eu2006.fi.

Baldwin, R. (2016). The great convergence: Information technology and the new globalization. Cambridge, MA.: Harvard University Press.

Baldwin, R. and Wyplosz, C. (2012). The economics of European integration. $4^{\text {th }}$ edition. Maidenhead: McGraw-Hill.

Bénassy-Quéré, A., et al. (2018). Reconciling risk sharing with market discipline: A constructive approach to euro area reform. CEPR Policy Insight 91, January. London: CEPR.

Claeys, G. and Sapir, A. (2018). The European globalisation adjustment fund: Easing the pain from trade? Bruegel Policy Contribution 5. Brussels: Bruegel.

Couré, B. (2017). Sustainable globalization: Lessons from Europe. Speech at the Workshop "Financial globalization and its spillovers - monetary and exchange rate policy in times of crises". Special public event " 25 years after Maastricht: The future of money and finance in Europe", February 16. Maastricht. Acquired from: https://www.ecb.europa. $\mathrm{eu} / \mathrm{press} / \mathrm{key} / \mathrm{date} / 2017 / \mathrm{html} / \mathrm{sp} 170216$.en.html.

Constantinescu, C., A. Mattoo and Ruta, M. (2017). Trade developments in 2016: Policy uncertainty weighs on world trade. February 21. Washington DC: World Bank Group.

Draghi, M. (2017). Sustaining openness in a dynamic global economy. Speech at the Economic Policy Symposium of the Federal Reserve Bank of Kansas City, Jackson Hole, 25 August. Acquired from: https://www.ecb.europa.eu/press/key/date/2017/html/ecb.sp170825.en.htm.

Eichengreen, B. (2018). The populist temptation: Economic grievance and political reaction in the modern era. Oxford: Oxford University Press.

Eichengreen, B. and Wyplosz, C. (2016). Minimal conditions for the survival of the Euro. In: Baldwin, R. and F. Giavazzi (eds.). How to fix Europe's monetary unions: Views from leading economists. London: A VoxEU.org eBook. CEPR.

European Commission. (2017). White paper and the future of Europe: Reflections and scenarios for the EU27 by 2015. Brussels: European Commission.

Funke, M., Schularick, M. and Trebesch, C. (2015). Going to extremes: Politics after financial crises, 1870-2014. CESifo Working Paper No. 5553. October. 
Guiso, L., H. Herrera, M. Morelli, M. and Sonno, T. (2018). Global crises and populism: The Role of Eurozone institutions". EIEF Working Papers Series 1806. Rome: Einaudi Institute for Economics and Finance.

Hennette, S., Piketty, T., Sacriste, G. and Vauchez, A. (2017). Pour un traité de démocratisation de l'Europe. Paris: Editions du Seuil.

IMF. (2017). World Economic Outlook April 2017. Washington DC: International Monetary Fund.

IMF. (2018). World Economic Outlook April 2018, Chapter 4. Washington DC: International Monetary Fund.

Lakner, C. and Milavonic, B. (2013). Global income distribution: from the fall of the Berlin Wall to the great recession. The World Bank. Policy Research Working Paper 6719, December. Washington DC: World Bank.

Lane, P.R. and Milesi-Ferretti, G.M. (2017). International Financial Integration in the Aftermath of the Global Financial Crisis. IMF Working Paper WP/17/115. Washington DC: International Monetary Fund.

Marin, D., Veugelers, R. and Felia, J. (2017). A revival of manufacturing in Europe. Recent evidence about reshoring. In: Veugelers, R. (ed.), Remaking Europe: The new manufacturing as an engine of growth (p. 102-125). Bruegel Blueprint Series 26. Brussels: Bruegel.

McCauley, R. (2011). De-internationalizing global banking? Comparative Economic Studies, 56(2), June, 257-270.

McCauley, R., Bénétrix, A.S., McGuire, P.M. and von Goetz, P. (2017). Financial deglobalisation in banking? Trinity Economic Papers No. 1717, July. Dublin: Trinity College.

Nordhaus, W.D. (2015). Are we approaching an economic singularity? Information technology and the future of economic growth. Cowles Foundation Discussion Paper No. 2021. New Haven, CT: Cowles Foundation.

Rodrik, D. (2011). The globalization paradox. Democracy and the future of the world economy. New York and London: W.W. Norton \& Co.

Rodrik, D. (2017). It's time to think yourself on free trade. Foreign Policy, January 27. Acquired from: https://foreignpolicy.com/2017/01/27/its-time-to-think-for-yourself-onfree-trade/.

Sander, H. (2011). Europe must grapple with the debt crisis now. The Conversation: Global Perspectives. May 18. Acquired from: https://theconversation.com/europe-must-grapplewith-debt-crisis-now-1264.

Sander, H. (2016). Renationalising fiscal policy would help rebuild support for the EU. EUROPP Blog: European Politics and Policy. London School of Economics and Political Science. Acquired from: http://bit.ly/2bAYUYx.

Tørsløv, T., Wier, L. and Zucman, G. (2018). The missing profit of nations. NBER Working Paper 24791. Cambridge, MA: NBER.

UNCTAD. (2017). World Investment Report 2017. Geneva: United Nations Conference on Trade and Development.

UNCTAD (2018). World Investment Report 2018. Geneva: United Nations Conference on Trade and Development.

Van Reenen, J. (2018). Increasing differences between firms: Market power and the macro-economy. Economic Policy Symposium of the Federal Reserve Bank of Kansas City, Jackson Hole, 29 July. 
Williamson, J. (1990). What Washington means by policy reform. In: J. Williamson, (ed.): Latin American readjustment: How much has happened. Washington DC: Institute for International Economics. 


\section{ANDRZEJ SOPOĆKO}

\section{Secular Structural Processes. Unexpected Results}

The economies of individual countries are increasingly integrated with their near - in terms of the main partners in foreign trade - and far environment, that is with countries supplying specific goods, necessary for production. It is impossible to run a business without constant analysis of what is happening outside the country, without keeping an eye even upon very distant areas. This fact is of fundamental importance for any economic policy. The processes taking place in the world economy system must be the starting point for any actions, both adaptive and protective against unfavorable events and processes (e.g. the flood of plastic garbage, transfer prices, etc.). These dependencies limit the scope of the state's activity, requiring a deep analysis of areas where its involvement is possible and effective. The experience of the old structural policy proves that direct interventions in the sphere of production don't have any potential left for the future. The issue of where it is possible now to accelerate the development through the influence of the state is one of subjects considered in this book. This part concerns one of the processes that seems to be viewed as a means of regulating activities. It is not so much a part of the economy as it is rather an area of social relations caused by economic mechanisms. This is a problem of growing property and social disproportions that cannot be reconciled with contemporary crucial values such as democracy and social solidarity. Counteracting this phenomenon is not the subject of the analysis presented here. That could be the next stage of work. Here, instead, the task is limited to answering the question: what and why contributes in the economy to the formation of income disparities. The author attempts to determine the reasons for the rich getting even richer and for the systematic reduction of the middle class in terms of income earned, embedded in the production mechanism itself. Particular emphasis was placed on inquiring how the processes of digitization, automation and application of artificial intelligence contributed to aggravation of this phenomenon.

Keywords: Income Disparities; Globalization; Digitalization; Securitization.

\section{Introduction}

Signum temporis of current transformations is an emergence of three factors which not only transform the economy but the society as well. These are: 
- securitization

- digitalization and artificial intelligence.

What these processes have in common is the surprising nature of their effects. Actually, they are not at all as suggested by our intuition or the so-called commonsense speculation. The observed phenomena turned out to be quite the opposite to what was expected. This was first discovered in the case of the globalization process.

Globalization, leading to deep international production specialization, should favor the use of local comparative advantages, raising the level of global prosperity. It turns out, however, that this process primarily took place in the group of highly developed countries, which moved towards an increasingly integrated production system, shaped inside an over-regional "global triangle" (North America, Europe, East Asia). Globalization has not contributed to the leveling of global income. Instead of the expected flow of capital from higherdeveloped countries to countries with lower GDP level, the reverse phenomenon, i.e. the so-called up hill capital flow (Prasad, Rajan and Subramanian, 2007) has been observed for years. As a result, differences between countries in the sphere of wealth of production assets have not decreased but deepened. It also turns out that globalization is also accompanied by increasing income differences within countries, especially in the less developed group. Jacek Tomkiewicz, basing on his own research and citing the work of Nomaan Majid, writes that: "the more open an economy is, the less the economic growth translates into a decline in poverty - rather than that, income inequalities grow faster" (Tomkiewicz, 2017, p. 29; Majid, 2010).

\section{The Most Important Processes Shaping the Production and Distribution System}

In purely economic sphere, the result of globalization is production dispersed all over the world. Complex products are assembled from components originating from various parts of the globe. This way, goods assembled somewhere, out of parts manufactured all over the world, lose their national identification in favor of identification with a supranational brand. This, in turn, leads to the internationalization of the management team, which at least has to represent cosmopolitan attitudes and a global, rather than national, point of view in its professional activities. In this situation, the role of states in shaping the 
production structure as well as social relations within the enterprise becomes very limited. The amount of wages and their structure is increasingly a reflection of global and not national dependencies and conditions. You pay as the global labor market dictates. While national regulations may improve the situation in a single company, there is a risk of it being excluded from the international product flow network.

The results of digitization and robotization in the economy are equally surprising. At the end of the last century, it seemed that they would reduce the demand for labor. After all, robots replace people, so the more robots there are, the fewer workers are needed. This, of course, is true but only on a micro scale. If, in one place, machines reduce the number of jobs, they create them at another place. After all, technologically sophisticated devices have to be manufactured and serviced somewhere. Their installation and maintenance require expert knowledge and qualifications. Developing appropriate organizational units that perform such tasks inside each enterprise is unprofitable. Instead, specialized service companies and workshops are created, serving enterprises that use devices of a certain type. The situation is similar as in the field of car repairs and maintenance. There used to be universal garages, dealing with vehicles of any brand. Currently, they are being replaced by specialized workshops licensed by specific manufacturers. In addition, specialization takes place also within them (e.g. there are workshops dealing specifically with gearboxes, electrics, etc.). Thus, there are many types of service companies that must be ready to sustain the complex system of the economy. They are able to relatively quickly remove failures and make changes in the machine park. Without them there would be downtimes and shortages, causing a sequence of losses in its near and far surroundings. With the appropriate experience and knowledge, such companies allow for smooth implementation of new procedures and products needed. Therefore, outsourcing is an inseparable element of development.

The most spectacular are services provided by programming centers, structuring the production, automation, etc. The demand for them grows up over proportionally to GDP, and this increases their price. Sought after employees in this area, aware of their relative scarcity, dictate the terms of employment. This is not only about pay, but also about the right offer of living conditions, which involves expensive infrastructure (housing, cultural offer, sports and leisure, etc.). Individual regions and even countries must meet these requirements, otherwise they will experience a dangerous drainage of this currently most valuable staff as it will move towards centers with a better offer of work and general living standard. 
A similar effect as the two previously described is triggered by the securitization of the economy. It is also unexpected, because even in the second half of the twentieth Century it seemed that this process, which contributes to dissemination of property, will, at the same time, help to offset income. While not everyone agreed with it, for a long time there were no indications of stretching the income structure as a result of this process.

It turned out, however, that securitization, seemingly only constituting a dissemination of property, caused a profound reduction of the owners' influence upon the production process. As a result, the importance of ownership supervision has been minimized. In fact, the role of a valuating body is no longer played by any statutory body of the company - instead, it is played by the stock market where share prices become the basic dimension of an enterprise valuation. Thus the strategic role of the owner becomes a fiction. Managers of the company (management board, CEO) decide on what enterprise is and what it will be. This in turn defines the entire enterprise strategy to a large extent. Because share prices are the current measure of its effectiveness, the mission of the executive bodies is to control them so that they are as high as possible during any managers' term of office. While it was traditionally believed that the managerial staff should identify itself with the product (Bata shoes, Leica cameras or Electrolux vacuum cleaners being good examples), nowadays identification with profit and profitability prevails. This leads to widening and changes in the production profile that will follow the industry efficiency rankings.

Nowadays, it is repeatedly emphasized that capitalism in the Schumpeterian sense is no longer there. Entrepreneurship ceases to be related to the ownership of capital. The functioning of large enterprises is extremely rarely decided by such personalities as the Michelin brothers, Ferdinand Porsche, and in Poland - Kazimierz Szpotański or Hipolit Cegielski. The contemporary model is a billionaire who has a constantly changing portfolio of financial assets. He meets his advisers every few days. Then he listens to which items of this portfolio he should exchange for others. The criterion is, of course, the shortterm effectiveness of the items in this portfolio, primarily - company shares. Apart from rare situations, the list of his business goals is limited to this one.

A typical capitalist does not manage these companies. In this process, he adopts passive attitude. He directs the energy not to the sphere of production but to the ongoing shaping of the portfolio. He chooses, and, in fact, accepts proposals to include assets in it, which currently offer a chance for the highest rate of return, getting rid of those whose prospects are poorer in this respect. However, he does practically nothing to increase their productivity. 
High-rank managers, including CEOs, work on the value of the company. Their strategy depends on whether the company's shares will achieve high enough dynamics to attract interest of owners of financial capital. Therefore, they try to squeeze the company as much as possible in the short term so that the obtained results attract investors' money. They work on effects which can interest the investors immediately - i.e. on short-term profits. Long-term development strategies in this situation become secondary.

In the situation of limited demand, the most promising action to increase profitability is to reduce costs. In the long run, you can do it through appropriate investments, but this perspective is rendered secondary. The most decisive managers in the company have several-years contracts. Hence, time horizon is crucial for them and it's over that time that they should demonstrate high efficiency. In these conditions, the most effective way to increase that efficiency is to reduce costs, especially their main component - wages. Thus, within a standard, large enterprise there is a mechanism to suppress the growth of wages, which explains, partially at least, the stagnation of the income median.

Thus, it can be said that in large corporations there is the following sequence of events:

- owners of financial capital are looking for opportunities to invest large amounts of funds into companies, offering high and stable rates of return in perspective of several years,

- managers of corporations, to be attractive to the owner of financial capital, focus their activity primarily on reducing wages, because in this period it is the most efficient way to increase the rate of return on the company's liabilities (capital),

- the result of such an attitude of managers is strong inhibition of income growth, which translates into the inhibition of the demand of people living from hired labor, i.e. income near or below the median.

Of course, the economy isn't entirely made up of large corporations. Also, they don't account for the majority of employees. However, it is not their participation in the creation of GDP but the importance in shaping the governance patterns that matters. Here, they face no competition. They are business leaders. Newspapers write about them and universities study them. The others watch the "big boys", presuming that the methods they use are the best, for how else would they have achieved their position? Therefore, we are dealing with a broad imitation of managerial actions of large corporations in the rest of the economy. This also applies to the attitude towards the wage growth. 
This phenomenon seems rather impossible to stop. The pattern of a company where savings are sought out, mainly in wages and employment, does not seem to have any viable alternative under today's intensified global competition. The resulting limitations in the growth of employees' income and the low demand they generate, it seems, must be accepted as an objective phenomenon. Some limitations are aided by the process of innovative enforcement (,you do not modernize, you are out of the market"), which creates a growing demand for employees with very high qualifications and intellectual efficiency. Statistics, however, of total wages indicate that this is not a dominant part, because otherwise their significant increase would be observed.

\section{The State and Threats of the Increase of Social Stratification}

Changes in the inter-branch relations of the economy and the related employment structure should be treated as a natural consequence of development. As mentioned, little can be done in this dimension, because the risk of off the mark patterns of the production structure is very high. The economy can set up its internal relations by itself and although it can be assessed in different ways, it is better to refrain from direct interventions. However, things are different in the social sphere. It is difficult to remain indifferent to consequences as they seem to smash the very foundations of the universal value system. We are now dealing with secular processes that shape the social stratification. They seem to noticeably undermine the achievements of the modern era in terms of democracy and social peace. The former class struggle seems to come down to an increasingly harsh confrontation of the growing group of dissatisfied with a small group of beneficiaries of changes in the upper income deciles.

Income variation is a natural effect of every economy. The utopian patterns of universal equality were never found anywhere, starting with the "utopia" of Thomas More and Tommaso Campanella ("The City of the Sun"), not to mention communism, whose verification cost lives of millions. Relatively most successful implementations of such systems, in the form of Israeli kibbutzim, by now have undergone far-reaching erosion, which makes longing for universal equality one of the myths that currently play no part in the economy.

However, while social egalitarianism is hardly an attractive social proposition now, the deterioration of the relationship between the poor and the rich increasingly provokes opposition. It is incompatible with the paradigm of equal opportunities that has replaced the myth of equality. A significant 
part of society believes that these chances decrease along with the income stratification. Getting better social position becomes very difficult for people from poor families. American myth, according to which anyone can go from rags to riches, nowadays only causes amusement.

Well, the possibility of a smooth promotion, i.e. a situation where everyone has a chance to move up to the level above, requires a proper social system. It should ensure the continuity of the vertical social structure, in which the individual rungs are relatively close to each other and within fairly equal distances. Therefore, it is not right that after reaching a certain position it is necessary to make a jump in the efforts and determination incomparable to previous stages. Unfortunately, social transformations carried out by economic changes are heading towards the latter. There is a clear tendency towards the formation of a dualistic model in which two layers are evident: the very well-off and the poor who struggle to maintain the standard of living above the edge of social exclusion. The group whose income was between rich and medium wealthy is shrinking. What once was a solid pillar of society, i.e. the middle class, is becoming less and less important, as the number of this group is constantly declining. One particular effect of these processes is the increase, specific to this structure of employment and income, in the number of people employed periodically and the exchange of job offers towards low-paid positions.

In this situation, it is difficult to resist the vision of the return of the social model from before the industrial revolution. In the eighteenth Century, in France, as well as in other European countries, there were two social groups in terms of income: the aristocracy and the rest, including peasants in the country and craftsmen in towns. While the aristocracy was prosperous and often extravagant, the rest often (during crop failures) suffered hunger. The aristocracy was under the protection of the king (who even repaid its debts repeatedly) and the rest of the population went through subsequent famines. The spectacular (and this is important) exemplification of this structure was Versailles, consisting of the palace where the king and the aristocracy lived (numbering about 3,000 ), and the town of Versailles, almost entirely inhabited by the servants of the latter (1789-60,000) (La Grande Encyclopédie, 1902, p. 886). The current reality, in some countries, hardly differs from this pattern. The Russian oligarchy took the place of the former aristocracy. As much as $16 \%$ of the Russian population lives below the poverty threshold, $10 \%$ of the richest have $87 \%$ of the country's wealth (in the USA $-76 \%$ of the wealth, in China - 67\%) (Walker, 2017). Similar relations are found in Latin American countries, otherwise known for frequent upheavals or even revolutions. The government is also the protector of the super-rich worldwide. Like aristocrats 
ones, nowadays big corporations are paying less and less taxes in the country. Google company is a curiosity because although it has its headquarters in the USA, and even employs mainly citizens of this country (combining employment of 88,000 ) (Statista, 2018), it does not pay a federal tax there. The state tax is also deeply reduced (only in Iowa, the total reduction of this tax amounted to USD 48 million) (Sverdlik, 2015).

Neither the eighteenth Century nor the currently erratic income "pyramid", however, arose due to the government's regulatory action. It was shaped by much stronger factors, having universal character.

In the past, income diversification was a natural consequence of the feudal system, based on the "good birth" and property criteria. Of course, assets remain a criterion for social diversification, but what is important too is the ability to enter and to stay in the upper social layer to which, other than the owners of capital, the so-called top management, free professions and some employees of science also belong. The problem is that the entry costs more and more. Thus a vicious circle is formed, in which the question of how to become rich is answered - be rich in the first place.

Statistics show that the income of the poorer sections of the population is not growing up, although the GDP is. This is happening both in the USA and in the European Union.

\section{Chart 1. Median income of people and GDP in the USA}

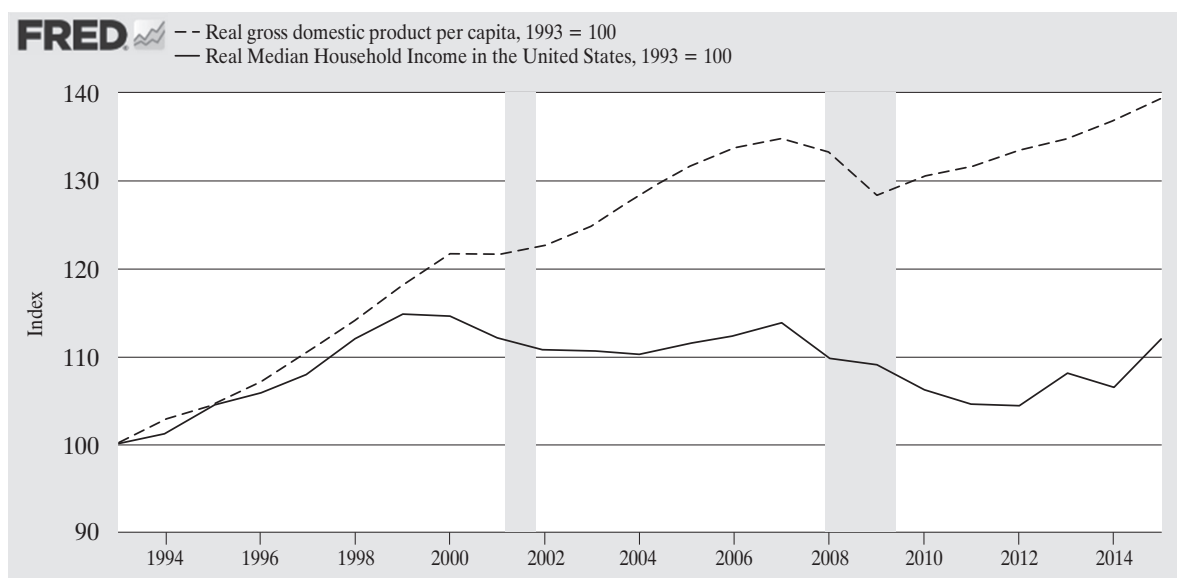

Source: U.S. Bureau of Economic Analysis, 2018.

It is the divergence of the GDP growth curves and the poorer half of the population that means acceleration of the process of the rich part of the society 
getting richer. Data in this area regarding the USA are widely known, and it does not seem necessary to reiterate them. It turns out, however, that this process takes place in the European Union as well, as can be seen in the chart below.

Chart 2. Increase in income in the income groups in the EU 19 countries

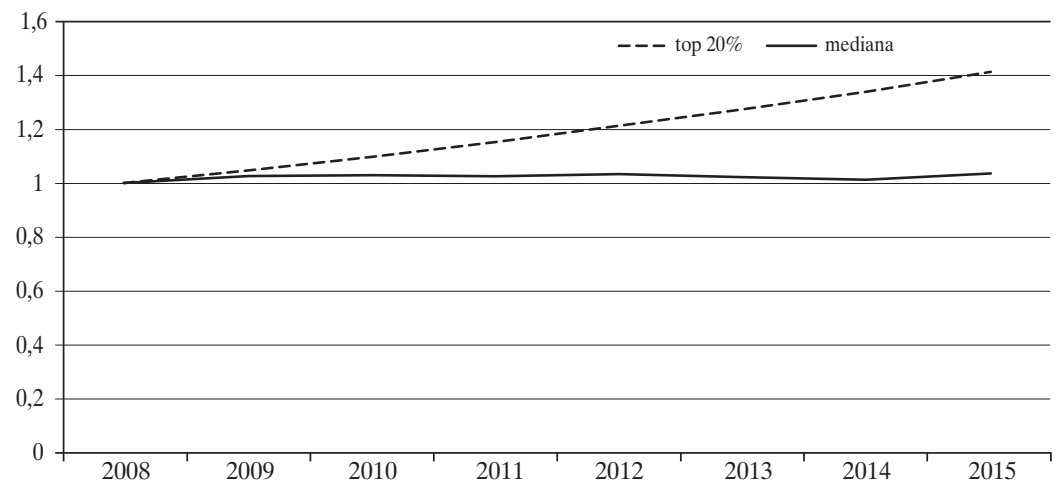

Source: OECD Statistics, 2018. Income Distribution and Poverty.

Both charts show that, in developed countries, the median income essentially does not grow despite GDP growth. It is stabilizing. This is happening both in the USA and in the nineteen wealthiest countries of Europe.

It is also interesting to observe that the stretching of the income structure of society does not occur along the entire length of the distribution. The changes occur in the second half of it and consist in an increasing takeover of the income volume by the richest. At the same time, what is in the poorer half, and thus below the median, essentially remains unchanged. It can be seen by comparing the tables below.

Although the data on the poorer half of society are very incomplete, there is no visible change in the relationship between the deciles and the median anywhere. On the other hand, the increase in the share of the richest decile is a common and significant phenomenon. This is of great social importance, but it also has economic and negative consequences for economic development.

Whereas in economic theory it is a margin, in the society major groups of people basically agree with Saya's law, not necessarily knowing that it was formulated 150 years ago. It it says that the rich create demand, just like the poor. Each monetary unit issued by their representatives has the same suction power in relation to the products being manufactured. Therefore, they create jobs, develop technology, etc. 
Table 1. Share of $10 \%$ of the richest in the total income

\begin{tabular}{|l|c|c|c|c|c|c|c|}
\hline & $\mathbf{2 0 0 1}$ & $\mathbf{2 0 0 2}$ & $\mathbf{2 0 0 3}$ & $\mathbf{2 0 0 4}$ & $\mathbf{2 0 0 5}$ & $\mathbf{2 0 0 6}$ & $\mathbf{2 0 0 7}$ \\
\hline USA & $42.20 \%$ & $41.20 \%$ & $41.80 \%$ & $43.70 \%$ & $45.70 \%$ & $46.50 \%$ & $47.20 \%$ \\
\hline France & $34.50 \%$ & $35.10 \%$ & $34.50 \%$ & $35.30 \%$ & $34.50 \%$ & $34.90 \%$ & $35.60 \%$ \\
\hline Germany & $36.20 \%$ & $36.10 \%$ & $35.50 \%$ & $36.00 \%$ & $38.50 \%$ & $38.40 \%$ & $39.60 \%$ \\
\hline Italy & $33.00 \%$ & $33.00 \%$ & $33.00 \%$ & $33.10 \%$ & $33.20 \%$ & $33.70 \%$ & $34.10 \%$ \\
\hline Japan & $39.60 \%$ & $40.60 \%$ & $41.20 \%$ & $42.10 \%$ & $42.40 \%$ & $42.80 \%$ & $43.00 \%$ \\
\hline Netherlands & $21.70 \%$ & $29.80 \%$ & $29.80 \%$ & $30.40 \%$ & $30.70 \%$ & $30.80 \%$ & $31.70 \%$ \\
\hline UK & $41.40 \%$ & $41.00 \%$ & $41.40 \%$ & $40.80 \%$ & $41.60 \%$ & $42.00 \%$ & $42.60 \%$ \\
\hline Sweden & $28.90 \%$ & $27.90 \%$ & $27.70 \%$ & $28.20 \%$ & $29.80 \%$ & $30.70 \%$ & $31.70 \%$ \\
\hline Switzerland & $31.90 \%$ & $31.20 \%$ & $31.30 \%$ & $31.60 \%$ & $31.90 \%$ & $32.60 \%$ & $33.30 \%$ \\
\hline & & & & & & & \\
\hline & $\mathbf{2 0 0 8}$ & $\mathbf{2 0 0 9}$ & $\mathbf{2 0 1 0}$ & $\mathbf{2 0 1 1}$ & $\mathbf{2 0 1 2}$ & $\mathbf{2 0 1 3}$ & $\mathbf{2 0 1 4}$ \\
\hline USA & $45.30 \%$ & $43.50 \%$ & $45.00 \%$ & $45.20 \%$ & $47.80 \%$ & $45.60 \%$ & $46.90 \%$ \\
\hline France & $35.90 \%$ & $35.40 \%$ & $36.10 \%$ & $37.90 \%$ & $38.00 \%$ & $36.40 \%$ & $37.00 \%$ \\
\hline Germany & $40.00 \%$ & $39.80 \%$ & $39.70 \%$ & $39.00 \%$ & & & \\
\hline Italy & $34.00 \%$ & $33.90 \%$ & & & & & \\
\hline Japan & $42.30 \%$ & $41.30 \%$ & $41.60 \%$ & & & & \\
\hline
\end{tabular}

* In 2015 this share amounted to $50.5 \%$.

Source: Sverdlik, 2015.

Table 2. Relationship between fifth and first decile of income distribution (P50/P10)

\begin{tabular}{|l|c|c|c|c|c|c|c|c|c|c|c|c|}
\hline & $\mathbf{2 0 0 2}$ & $\mathbf{2 0 0 3}$ & $\mathbf{2 0 0 4}$ & $\mathbf{2 0 0 5}$ & $\mathbf{2 0 0 6}$ & $\mathbf{2 0 0 7}$ & $\mathbf{2 0 0 8}$ & $\mathbf{2 0 0 9}$ & $\mathbf{2 0 1 0}$ & $\mathbf{2 0 1 1}$ & $\mathbf{2 0 1 2}$ & $\mathbf{2 0 1 3}$ \\
\hline USA & & & & 2.7 &.. &.. & 2.7 & 2.6 & 2.7 & 2.7 & 2.7 & \\
\hline France & & & & 1.8 &.. &.. & 1.8 & 1.8 & 1.9 & 1.9 & 1.9 & 1.9 \\
\hline Germany & & & & & & & 1.9 &.. &.. & 1.9 & 1.9 & 1.9 \\
\hline Italy & & & & & & & & 2.6 &.. &.. & 2.6 & \\
\hline Japan & & & & & & & & & 1.8 & 1.8 & 1.9 & 1.9 \\
\hline Netherlands & & & & & & & & 1.8 & 1.8 & 1.9 & 1.9 & 1.9 \\
\hline UK & 2.2 & 2.1 & 2.1 & 2.1 & 2.2 & 2.2 & 2.1 & 2.1 & 2.1 & 2 & 2 & 2 \\
\hline Sweden & & & 1.7 &.. &.. &.. & 1.9 & 1.9 & 2 & 2 & & \\
\hline Switzerland & & & & & & & & 2 &.. & 2 & & \\
\hline
\end{tabular}

Source: Sverdlik, 2015.

Well, it is simply not true. Firstly, the rich have greater propensity to save. Secondly, the demand of the rich is different than poorer people's demand. Not only is the difference in the quality of goods sought after, but also the impact 
of the expenditure of these groups on the intensity of production processes. In fact, the demand of rich people is less and less directed towards goods produced in the economy. There are currently two areas for this group where there is the highest expenditure dynamics. The first of these is the purchase of rare goods. For 10 years now we are witnessing the highest rate of return on the market of funds investing in works of art. It is $8 \%$ now, with the rate of economic growth oscillating somewhere around $0.5-1 \%$ (Alindogan, 2015). Another group is real estate market. The interest in it is illustrated by the increase in the housing price index.

Chart 3. Index of housing prices in Europe

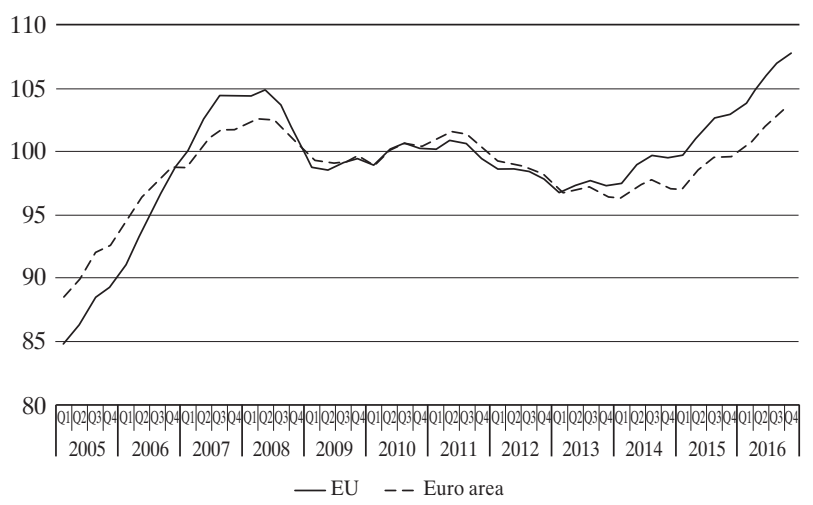

Source: Eurostat, 2016. House price indices - euro area and EU aggregates; Index levels $(2010=100)$, 2016Q4.PNG.

Chart 4. Index of housing prices in the USA. Quarterly data

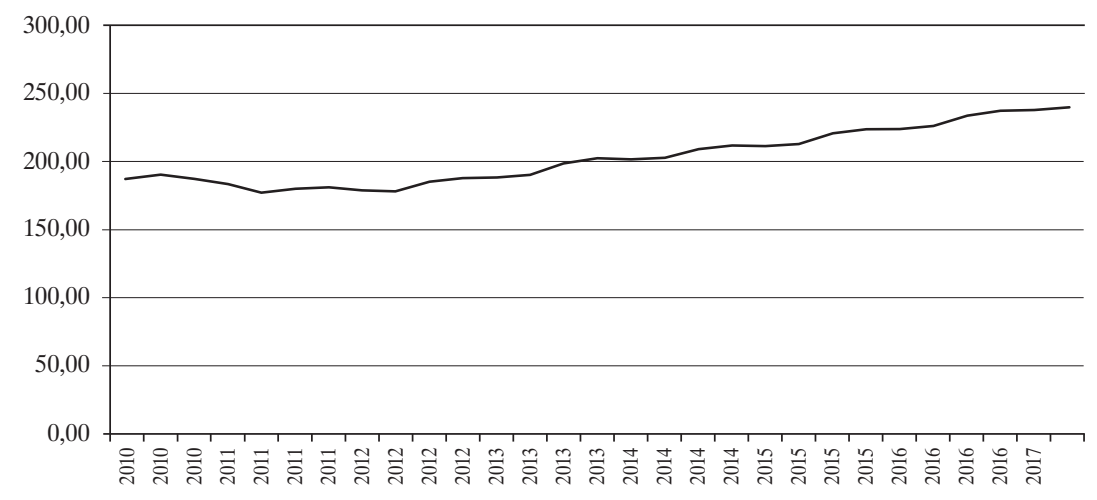

Source: Federal Housing Finance Agency. House Price Index Datasets. Purchase-Only Indexes (Estimated using Sales Price Data). 
In the US, the increase in housing prices is a bit slower than in Europe, but since 2012 , it systematically exceeds $5 \%$ annually.

The next area fed by the richest percentiles is speculation. Its area is growing, which is not indifferent to the economy and not necessarily because of possible price bubbles. Indeed, the conviction that in speculation, some win what others lose is only a partial truth. The problem is that speculation sucks up money. According to the calculations of the author three years ago, the amount of money absorbed only by trade in derivatives is an amount more or less the order of German domestic income (Sopoćko, 2016). That was it, three years ago. The increase in this amount was then around 6-7\%. It can be said that a significant amount of money is actually sucked up by the needs of turnover itself.

\section{Employment in the Era of Digitization}

As already mentioned, the $21^{\text {st }}$ Century is not a period when jobs are in short supply. In an age of unprecedented acceleration of automation, there is simply a deficit of employees. And not only in specific areas. The deficit is general. This is shown by current statistics and forecasts for the future.

\section{Chart 5. Unemployment rate in the USA after World War 2}

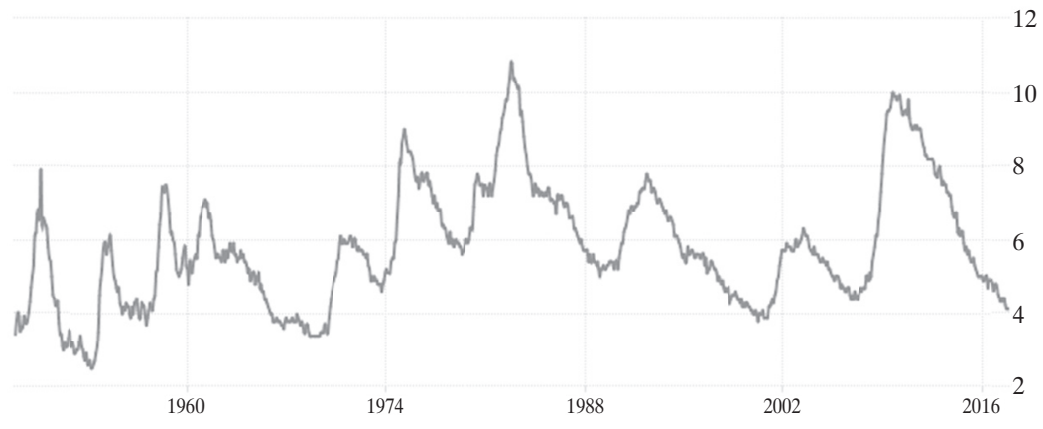

Source: Tradingeconomics.com. U.S. Bureau of Labor Statistics.

The lack of connection between the drop in new jobs and the unemployment rate is quite straightforward. Work resources in a modern, highly developed economy are growing (as potential) quite slowly, which is explained by the aging 
of society. Potential employees are coming, but mainly not due to new births - rather to the extension of life expectancy. In addition, such reserves as the possibility of higher professional activation of women are virtually exhausted.

At least in the near future, there is no threat of unemployment calculated in absolute terms. For example, the U.S. Congressional Budget Office foresees, for example, full employment in 2020, that is the elimination of unemployment in its value to the level of NAIRU (Non-Accelerating Inflation Rate of Unemployment). This means closing the gap in the labor demand that arose as a result of the subprime crisis. In this way, in 2020, the value of potential GDP is to be the same as the actual one. It is accepted in this country that the potential for growth is practically determined by employment - until, of course, when the increase in labor demand begins to accelerate inflation.

Table 3. Selected levels and dynamics of GDP in the U.S. in billions of dollars, by value from 2005

\begin{tabular}{|l|c|c|c|}
\hline \multicolumn{1}{|c|}{ GDP type } & $\mathbf{2 0 1 0}$ & Project 2020 & Growth rate \\
\hline Actual & 13,0880 & 17,5129 & $3.0 \%$ \\
\hline Potential & 14,0171 & 17,5129 & $2.3 \%$ \\
\hline
\end{tabular}

Source: Dubina, 2017.

The table shows that the presented projection assumes a complete exit from the extreme of the economic downturn at the beginning of the next decade. It is connected with a higher use of the labor resource, which in the initial period was significantly below the NAIRU rate. Thus, by using this cyclical reserve, the growth rate of real income is more than of the potential one (by $0.7 \%$ ). If this reserve was not there, GDP would grow, with the current inflation rate remaining, by $2.3 \%$ (Dubina, 2017).

The presented projection concerns a short period; however, that does not change its value. Because it is adopted by a government agency, it is important for future analyses. Such forecasts are usually the basis for government action, so they must be made very responsibly. In this case, it can be assumed that, based on the existing data, the U.S. government does not expect any increase in unemployment in the nearest future, which could be due to the automation of the work process. Similar conclusions can be drawn by observing a strong decline in this indicator last year in the European Union.

In Japan, where unemployment has traditionally been at a very low level, now records are being set in this respect. This is happening in the country with the highest achievements in the field of robotic construction and automation of technological processes. 


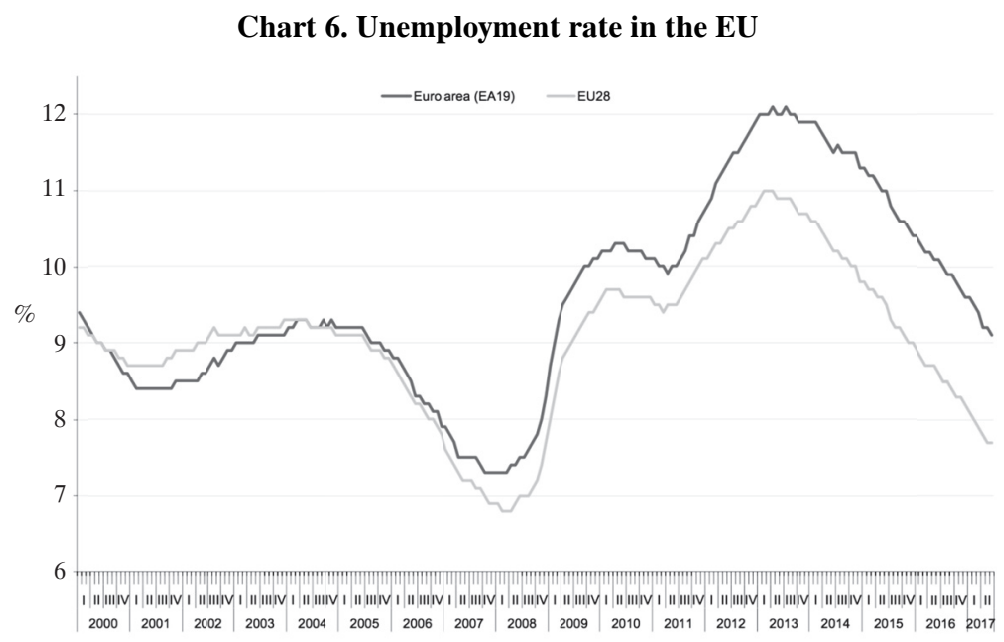

Source: Bowman, 2017.

\section{Chart 7. Unemployment in Japan}

Japan Unemployment Rate

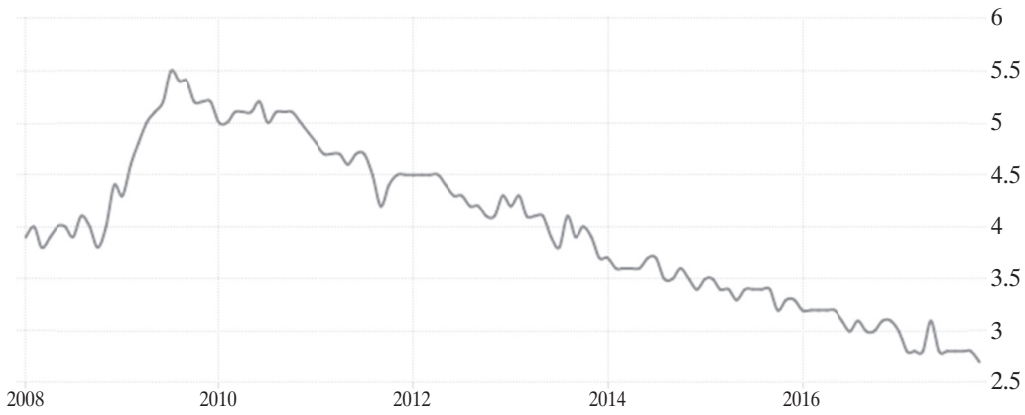

Source: Trading Economics, 2017.

These empirical data in no way confirm the tendency to reduce employment as a result of the $21^{\text {st }}$ Century industrial revolution. On the other hand, the logic of running replacement processes requires caution. In perspective of a few or maybe a dozen or so years, the trend may reverse. Therefore, the scenario in which the number of job offers in general will decrease should not be rejected. Currently, however, there is no so-called "hard data" in this respect. 
For now, in the global economy of automation and digitization, there is a decrease in unemployment (!), with the simultaneous increase in the number of various warnings about its imminent growth. The latter are not as much as systemic in nature, but rather stem from the observation of new technology products. While it is even possible to count how many jobs automation replaces, it is difficult to estimate how many, directly and indirectly, it simultaneously creates. It is relatively easy to determine trends in existing occupations, it is almost impossible to determine the increase in jobs due to the use of breakthrough inventions. How many people will you need for autonomous vehicles to maintain the infrastructure and to protect them against interference? How many people will find a job in creating and distributing virtual reality software and devices, etc.? For the time being, it is not possible to answer these questions reliably.

Digitization and automation create problems that will have to be solved with the help of qualified employees. It is important that these processes do not get out of control, to protect the system from viruses, hacker attacks, etc. The need to create new computer software will probably still exist for a long time. Therefore, this will provide jobs for programmers, but also for the personnel necessary for servicing existing computers, defending them against hacking, etc.

It seems that when assessing and analyzing possible scenarios of the application of digitization and automation, one should deviate from the approach set out in the question: what it replaces. These two phenomena do not replace elements of the production system, they change the whole system. And so, they are not limited to replacing, for example, routine, manual work. This approach does not reflect the essence of change. As M. Osborne and C. Frey write (Osborne and Frey, 2011) “... the key aspect is not so much the use of computers, but broad changes in the organization that IT technology allows for. The most productive companies reorganize the decision-making, motivational, information flow, and recruitment system and other components of the organization to get the most out of the new technology." Profound changes are taking place, in which some jobs disappear, others appear. What the balance of these changes will be - it is difficult to predict. There are too many variables, degrees of freedom and information gaps. We do not know all the possibilities of a new technology, nor the limits of its adaptation by people. Therefore, the current trend of creating jobs due to new technology (and not their reduction) is taking place and is also has logical justification. And there are events that trigger whole sequences of changes in the areas that deal with industries where they are directly observed. Computers replace activities, but a whole infrastructure is created around them. According to the aforementioned authors, 1 dollar spent on computers 
requires 10 dollars turned into the functioning of the network, peripherals, etc. Specialized employees are needed for that.

As it turns out, the characteristic feature of the current changes in employment is not the reduction of jobs, but their restructuring. In some areas, employment will probably fall, in others it will increase, however, the balance of changes seems to be positive. In the USA, it is estimated that despite quite deep shifts in job offers, the future is rather optimistic. Indeed, employment is expected to increase, and predicted to do that faster than before. While the employment growth in 2006-2016 amounted to around $0.5 \%$ annually, in the next decade $0.7 \%$ is forecasted, compared to a $0.6 \%$ increase in labor force (BLS News Relase, 2017). Therefore, in the next decade, there are more jobs than there are people at working age. In addition, all this will take place under conditions of high productivity growth. According to the BLS, it is to amount to $1.6 \%$ per annum in the decade $2017-2026$, against a significantly weaker one $(1.2 \%)$ in the previous decade (BLS News Relase, 2017). According to official American forecasts, the phenomenon of job losses due to automation and artificial intelligence is not expected in this country. Similarly, in the Euro zone, where unemployment is expected to decline in this decade ${ }^{1}$.

The situation regarding the possible reduction and demand for work due to the automation and digitization of the process can be seen as a divergence of two worlds:

Real. The latest empirical data do not indicate a reduction in the volume of jobs, but even an increase in their offers.

Social awareness. There is a widespread expectation that automation and digitization will increase unemployment.

\subsection{Structural Changes}

According to American data (Bureau of Labor Statistics - BLS), in the 30 most-threatened occupations, 11.5 million jobs will be lost by 2026. These include locomotive operators, watchmakers, call center employees, secretaries, mail workers, employees of the copy rooms, etc. The average earnings in these occupations fall within the limits of 30-50 thousand USD per year'2.

On the other hand, a significant increase in jobs in other occupations is expected. The largest - in the following:

1 The ECB predicts that within 5 years in Eurostat unemployment will decrease from the current (4Q 2017) 9.1\% to 7.9\%. ECB Unemployment rate forecast.

2 Bureau of Labor Statistics. Employment projection. Table 1.5 Fastest declining occupations, 2016 and projected 2026, October 24, 2017. 
Table 4. Expected increases in employment in selected occupations in 2016-2026

\begin{tabular}{|l|c|}
\hline installers of photovoltaic panels & $105.30 \%$ \\
\hline service engineers for wind turbines & $96.10 \%$ \\
\hline home medical assistance & $46.70 \%$ \\
\hline personal care & $37.40 \%$ \\
\hline medical assistants & $36.00 \%$ \\
\hline nurses & $33.40 \%$ \\
\hline statisticians & $33.40 \%$ \\
\hline therapists & $30.80 \%$ \\
\hline software programmers & $30.50 \%$ \\
\hline mathematicians & $29.40 \%$ \\
\hline
\end{tabular}

Source: BLS News Release, 2017.

Arwa Mahdawi in her article from January 26, 2017 lists the five occupations most endangered by the automation, the chances of automation in parentheses (Mahdawi, 2017): telemarketing (99\%), credit rating specialists (98\%), legal office personnel (98\%), cashiers $(97 \%)$, taxi drivers $(89 \%)$, fast-food cooks $(81 \%)$. The least endangered are, according to this newspaper: psychotherapists $(0.3 \%)$, personal couches $(35 \%)$, nutritionists $(0.39 \%)$, doctors and surgeons $(0.42 \%)$, clerics $(0.81 \%)$.

Some of these items are quite surprising, such as banking analysts or legal office personnel. Hardly anybody is currently able to comprehend the scope of the appearing computer applications. Some of them have moved out of the search phase, finding conjunctions, comparing with a given pattern, etc. The era of self-learning systems is coming, allowing for the process of writing pleas or detailed analysis of the client's standing and chances of maintaining income to pay off the debt. On the other hand, the professions considered in this article as essentially non-threatened seem to be compatible with intuition. We have not yet found ways to make computers feel empathy, be good advisers on aesthetic issues or direct films. It is possible to computerize activities, but it is difficult to shape the personality of an electronic partner this way and get such features of its functioning, which people are used to (humor, inventiveness of reports, willingness to interest the interlocutor). In these professions where direct contact with people is the starting point for business success the machines will probably take over only a marginal part of the work being done.

Automation and artificial intelligence seem to relatively quickly master the sphere of production of goods, although certain areas of the sphere (design, public relations, creation of promotional activities) will remain outside it for 
a longer time. Workers will pass there, but it must be remembered that the area from where they can go is shrinking. In the industry, where robotization is marking its presence more and more noticeably, in the OECD countries, only $22 \%$ of employees are currently employed, $18 \%$ in Great Britain, $17 \%$ in the USA. In China, an industrial area of the world, $22 \%$ of all employees are employed in the industry (World Bank, 2017).

In the sphere of services, automation has made and probably will make significant progress, especially in transport and trade. On the other hand, employment growth can be expected in certain service areas. It's all about professions requiring interpersonal contacts. The enrichment of upper income decile (more on that further in the text) must increase the demand for services in the field of body care, recreation as well as services usually performed by household members (cleaning). It's hard to imagine robots making manicure or cleaning Sèvres porcelain. It will rather remain the domain of crafty human hands.

Considering all employees, significant changes in the occupational structure are expected. This process began even earlier, in the 1990s, when automation and digital control appeared on a large scale. In the decade to come, it is expected that $14 \%$ of the world's population will have to change jobs (2.6 billion people). The greatest needs of changes will occur in highly developed countries: the USA - at least $32 \%$, Japan - 46\%, Germany - 33\%. In total, in developed countries, it is expected that $1 / 3$ of all employees will change occupations, compared to around 9\% in developing countries (Manyika, Lund, Chui et al., 2017, p. 11).

These quantities define the scale of the social stress. Changing the occupational profile, for obvious reasons, requires a lot of effort (new qualifications, implementation in new activities, conversion of perception to other areas). However, if it concerns a significant part of employees (from one third to a half), it generates a sense of danger for everyone. From the point of view of the relationship employer - employee, this is not a good situation for the latter. The bargaining power, and the motivation to negotiate working conditions and pay, are poor. There are psychological reasons for concern about keeping a workplace in a situation when more and more people are being laid off. That is, those who will be objectively needed in the conditions of new technologies will also be afraid. The data presented a little further show that work will not be difficult to come by at all, at least not more difficult than at present. However, the transition from one job to another does not have to be immediate. Loans, though, have to be paid regularly, just like rent. In both cases, there is a growing tendency on the expenditure side. Households are 
becoming more and more indebted, and rents, as prices of real estate increase, go up as well.

In perspective of at least one generation, the social situation in this area does not seem to change. So far, current trends are very strong. Increasing wage disparity has clearly occurred in the econometric analysis of the wage stratification process carried out by the author (Jaworski and Sopoćko, 2017). Data from 2002-2015 indicate that the increase in national income causes very rapid enrichment of the upper deciles of the income structure, and stagnation, or even a decline of income in the poorer part of society. The indices of income elasticity against GDP calculated on the OECD Statistic database show that the median income of the population does not keep up with the increase in national income. The value of $\beta$ in regression equations for individual countries is always below unity, and sometimes it is negative (UK - 0.92, Germany - 0.691, France -0.831 , USA -0.995 , Italy - minus 0.472 , the Netherlands - minus 0.631 , Japan - minus $0.341^{3}$ ). In turn, the elasticity of the highest decile income in relation to GDP in all the countries studied is above unity, and sometimes above two (Germany -2.148, France -1.365, Great Britain 1.298, USA -2.336 Italy - 1.034, the Netherlands -1.466 , Japan $-1.843^{4}$ ).

These data for Europe, in the face of relatively low GDP growth, practically stagnate the income of the poorer part of society. In the USA, the GDP growth rate was higher than in Europe and Japan, but this cannot be considered a positive phenomenon, because it was related to the increase in income disparities. The median income in this country over the 15 years of the $21^{\text {st }}$ Century was lower than at the end of the last decade of the $20^{\text {th }}$ Century 5 .

Under these conditions, the assessment of the labor market in the next 10 years, considered as the period of expansion of automation and digital control, does not appear unambiguous. Unemployment in developed countries shows a downward trend but the majority of society does not benefit from it. The rich are getting even richer faster and faster, half of the population remains at a stable level of real income. Benefits from the growth of labor productivity are not likely to affect it. The new technical revolution contributes to that. Here is the forecast of wage dynamics in the U.S. for individual deciles of its structure:

The significance test for this parameter of regression function was above 0.9.

Parameter values calculated with a confidence limit exceeding 0.95 .

Vide Table A-2. Selected Measures of Household Income Dispersion: 1967 to 2016, United State Census Bureau 2017. 
Chart 8. Expected rate of wage growth $(\%)$ in individual wage deciles in the U.S. in 2016-2030

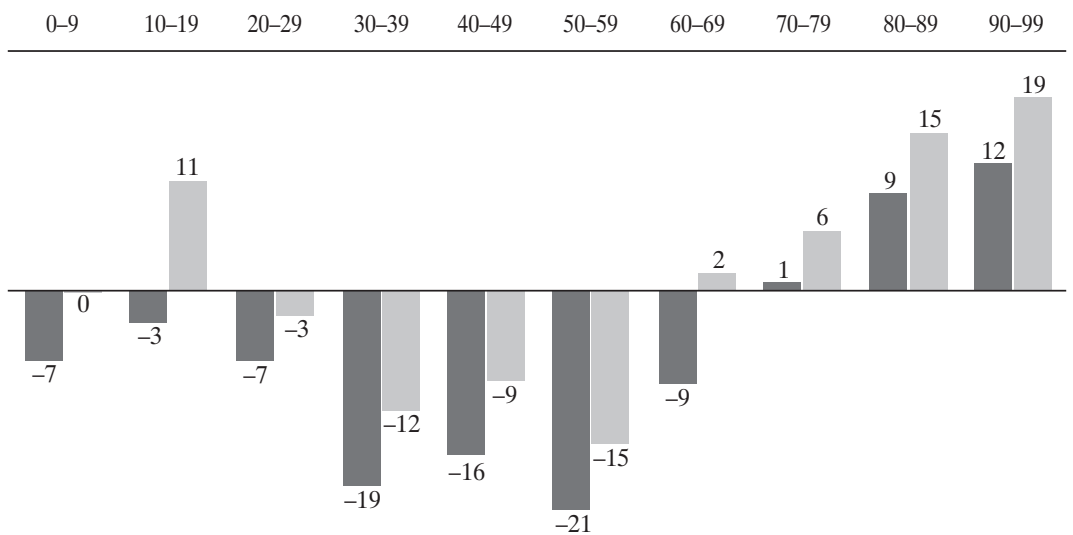

Source: Manyika, Lund, Chui, Bughin, Woetzel, Batra, Ko and Sanghvi, 2017, p. 89.

This chart shows the already mentioned phenomenon of the drop in the income in the middle groups, in the face of, in fact, their stabilization (in total) in the group of $1 / 3$ of the poorest. A definitely high growth is expected in the group of the highest earners. In Germany, stabilization is expected in $2 / 3$ of the total population, divided according to income, and an increase is expected in the highest-earning third part. In Japan, real incomes fall is expected in general, but the largest in the middle group and the smallest among the best earners (Manyika, Lund, Chui et al., 2017, p. 88).

Due to the differences in social welfare systems and the redistribution of income, the assumptions regarding the strength of changes in its structure in developed countries must be cautious. However, the thesis about the deterioration of the middle class in the period of changes that seem to occur in the next generation period now has a rational and empirical basis.

\section{Conclusions}

Social change seems to be currently heading towards a bipolar society, that is one in which there is a group of rich people and the rest - not at all poor, but separated from the former by a significant income band. This means reduction of the middle class (in statistical terms), which, unlike in previous epochs, is becoming less and less significant for the development of civilization. The main 
driving force behind this process is the ongoing revolution of digitization and automation. Contrary to recent expectations it does not reduce the number of jobs. However, there is a deep restructuring of employment, which rewards people with high intellectual abilities, significant knowledge and expert qualifications in a disproportionally high manner. Others are also needed, but in this group it is easy to replace one man with another, whereas in positions with high requirements this procedure is much more difficult and this results in high wages. The possibility of their leaving creates a threat of destabilization of the manufacturing process, natural in the case of the loss of specialists who are key to smooth operation of factories and service delivery systems.

Undoubtedly, the aforementioned revolution will acknowledge the increase in the volume of social prosperity, it's just that the change mainly benefits the highest income deciles. This creates a gap not only in the level of individual consumption, but also in access to social benefits, in particular health and education. Where they are paid for, they become a barrier to migration between social strata, and the pattern of a society of equal opportunities shifts more and more into the realm of illusion. In countries where access to these services is widespread, the bipolarity of social development risks appears to be smaller, though they will rather not disappear. High differences in the standard of living also contribute to other phenomena, such as inequalities in the disposal of the assets, including production, which has further significant social consequences.

\section{References}

Acemoglu, D. and Robinson, J. (2013). Why Nation Fail. The origins of Power, Prosperity and Powerty. London: Profile Books Ltd. (p. 73-75).

Alindogan, M. (2015). Van Gogh's painting sells for \$66M, nearly six times its 2003 price. AOL News, 6 May. Acquired from: http://www.aol.com/article/2015/05/06/van-gogh-spainting-sells-for-66m-nearly-six-times-its-2003-pr/21180474/.

Allen, R.C. (2009). Engels' pause: Technical change, capital accumulation, and inequality in the British industrial revolution. Explorations in Economic History. https://doi.org/10.1016/j. eeh.2009.04.004. Acquired from: https://www.nuff.ox.ac.uk/Users/Allen/engelspause.pdf.

BLS News Relase. (2017). Employment projections 2016-26. U.S. Department of Labor, 24 October. Acquired from: https://www.bls.gov/news.release/pdf/ecopro.pdf.

Bowman R. (2017). Unemployment in the Eurozone has fallen to its lowest level since 2009. World Economic Forum, 3 August. Acquired from: https://www.weforum.org/ agenda/2017/08/unemployment-falls-optimism-rises-in-eu/.

Brynjolfsson, E. and McAfee, A. (2011). Why Workers Are Losing the War Against Machines. The Atlantic, 26 October. 
Brynjolfsson, E. and McAfee, A. (2014). The Second Machine Age. Work, Progress, and Prosperity in a Time of Brilliant Technologies. New York: W.W. Norton \& Company.

Deloitte. (2016). Art \& Finance Report 2016. Luksemburg: Deloitte, ARTTactic. Acquired from: https://www2.deloitte.com/content/dam/Deloitte/at/Documents/finance/art-andfinance-report2016.pdf.

Dubina, K.S. (2017). Full employment: an assumption within BLS projections. Monthly Labor Review. U.S. Bureau of Labor Statistics, November, https://doi.org/10.21916/ mlr.2017.30. Acquired from: https://www.bls.gov/opub/mlr/2017/article/full-employmentan-assumption-within-bls-projections.htm.

Employment protection. (2017). U.S. Bureau of Labor Statistics. Acquired from: https://www. bls.gov/emp/tables/emp-by-detailed-occupation.htm (24.10.2017).

European Central Bank. (2018). ECB staff macroeconomic projections for the euro area. March.

Acquiredfrom: ttps://www.ecb.europa.eu/pub/pdf/other/ecb.ecbstaffprojections201803.en.pdf.

Eurostat. (2016). House Price Statistic_House Price Index. Acquired from: https://ec.europa. eu/eurostat/statistics-explained/index.php/Housing_price_statistics_-_house_price_index euro area and EU aggregates Index levels 2010100 2016Q4.PNG.

Jaworski, P. and Sopoćko, A. (2017). Impact of income distribution on the economic growth. Conference Oxford University and Bilbao University, 28-29 June.

Kelso, L.O. and Hetter, P. (1967). Two-Factor Theory. The Economics Of Reality: How to Turn Eighty Million Workers into Capitalists on Borrowed Money and Other Proposals. New York: Random House.

Kurland, N.G. (2001). A New Look at Prices and Money: The Kelsonian Binary Model for Achieving Rapid Growth Without Inflation. The Journal of Socio-Economics, 30(6), 495-515. https://doi.org/10.1016/S1053-5357(01)00121-4. Acquired from: https:// www.researchgate.net/publication/4932117_A_New_Look_at_Prices_and_Money_The_ Kelsonian_Binary_Model_for_Achieving_Rapid_Growth_Without_Inflation.

Mahdawi, A. (2017). What jobs will still be around in 20 years? Read this to prepare your future. The Guardian, 26 June. Acquired from: https://www.theguardian.com/ us-news/2017/jun/26/jobs-future-automation-robots-skills-creative-health.

Majid, N. (2010). On the Income Dimension of Employment in Developing Countries. Employment Sector. Employment Working Paper No. 72. International Labour Office. Geneva. Acquired from: http://www.ilo.org/wcmsp5/groups/public/---ed_emp/---emp_elm/--analysis/documents/publication/wcms_151802.pdf.

Manyika, J., Lund, S., Chui, M., Bughin, J., Woetzel, J., Batra, P., Ko, R. and Sanghvi, S. (2017). Jobs Lost, Jobs Gained: Workforce Transitions In A Time Of Automation. McKinsey Global Institute, December. Acquired from: https://www.mckinsey.com/ / media/McKinsey/Featured $\% 20$ Insights/Future $\% 20$ of $\% 20$ Organizations/What $\% 20$ the $\% 20$ future $\% 20$ of $\% 20$ work $\% 20$ will $\% 20$ mean $\% 20$ for $\% 20$ jobs $\% 20$ skills $\% 20$ and $\% 20$ wages/ MGI-Jobs-Lost-Jobs-Gained-Report-December-6-2017.ashx.

Osborne, M.A. and Frey, C.B. (2013). The Future of Employment: How Susceptible Are Jobs to Computerisation? Oxford Martin School, University of Oxford, Working Paper, 17 September.

OECD Statistics. (2018). Income Distribution and Powerty. Acquired from: https://stats. oecd.org/Index.aspx? DataSetCode=IDD.

Piketty, T. (2015). Kapitat w XXI wieku. Warszawa: Wydawnictwo Krytyki Politycznej. 
Prasad, E., Rajan, R. and Subramanian, A. (2007). The Paradox of Capital. Finance \& Development. A quarterly magazine of the IMF, 44(1).

Rotman, D. (2013). How Technology Is Destroying Jobs. MIT Technology Review, 12 June. Acquired from: https://www.technologyreview.com/s/515926/how-technology-is-destroyingjobs/.

Rzońca, A. (2014). Kryzys Banków centralnych. Skutki stopy procentowej bliskiej zera. Warsaw: C.H. Beck.

Saez, E. and Zucman, G. (2014). Wealth Inequality in the United States since 1913: Evidence from Capitalized Income Tax Data. NBER Working Paper 20625, October.

Sopoćko, A. (2015). Mit pieniądza. Realna gospodarka wobec iluzji polityki monetarnej. Warsaw: PWN.

Sopoćko, A. (2016). Polityka emisji pieniądza procesie zrównoważonego wzrostu. In: J. Kleer, K. Prandecki (eds.), Ekonomiczna pozycja Europy w świecie. Warsaw: Komitet Prognoz „Polska 2000 Plus”.

Spannagel, D. (2015). Trotz Aufschwung: Einkommensungleichheit geht nicht zurück. WSIVerteilungsbericht 2015. WSI-Mitteilungen,8. Acquired from: https://www.boeckler.de/ wsi-mitteilungen_62503_62548.htm.

Statista. (2018). Number of full-time Alphabet employees from 2007 to 2017. The Statistics Portal. Acquired from: https://www.statista.com/statistics/273744/number-of-full-timegoogle-employees/.

Stierli, M., Shorrocks, A., Davies, J.B., Lluberas, R. and Koutsoukis, A. (2015). Global Wealth Report 2015. Zurich: CREDIT SUISSE AG Research Institute, October. Acquiredfrom:http://publications.credit-suisse.com/tasks/render/file/index. $\mathrm{cfm}$ ?fileid=F2425415-DCA7-80B8-EAD989AF9341D47E.

Sverdlik, Y. (2015). Iowa Officials Approve Tax Breaks for Google Data Center Expansion. Knowledge \& Networking Division of Informa PLC, Data Center Knowledge, 17 April. Acquired from: http://www.datacenterknowledge.com/archives/2015/04/17/iowa-officialsapprove-tax-breaks-for-google-data-center-expansion.

Tomkiewicz, J. (2017). Dynamika i struktura dochodów w warunkach globalizacji. Warszawa: PWN.

TradingEconomics.(2017).Acquired from: ttps://tradingeconomics.com/japan/unemploymentrate, 26 December.

TradingEconomics.(2018).Acquired from: https://tradingeconomics.com/united-states/ unemployment-rate, 3 August.

United State Census Bureau. (2017). Table A-2. Selected Measures of Household Income Dispersion: 1967 to 2015. Acquired from: https://www2.census.gov/programs-surveys/demo/ tables/p60/256/table4.xls.

U.S. Bureau of Economic Analysis. (2018). Real Gross Domestic Product [GDPC1]. FRED, Federal Reserve Bank of St. Louis, 3 September. Acquired from: https://fred.stlouisfed. org/series/GDPC1.

Walker S. (2017). Unequal Russia: is anger stirring in the global capital of inequality? The Guardian,25,April.Acquired from:https:/www.theguardian.com/inequality/2017/apr/25/ unequal-russia-is-anger-stirring-in-the-global-capital-of-inequality.

World Bank. (2017). Employment in industry (\% of total employment). Acquired from: https://data.worldbank.org/indicator/SL.IND.EMPL.ZS?view= chart 


\title{
Control of Capital Against the Middle Income Trap
}

\begin{abstract}
Developing countries now significantly advanced in development, which include Poland, have much lower productivity of production factors, including workforce productivity. Among the reasons for that, essential is the unfavorable division of labor in the global value creation chain. Such a condition in the post-socialist countries results from several important factors, among them accelerated privatization, mainly with the participation of foreign capital, as well as the structure of foreign direct investments. The national economy is dominated by foreign corporations that invested labor-intensive production processes in these countries, using cheap labor. The subordinate role of local production has been strengthened by the globalization process. These countries may be caught in the trap of medium development, and currently operate in a peculiar lower league of the world economy. The inferior role of local subcontractors is due to the fact that they do not participate in the capital ownership of companies and thus have little influence on the power of international corporations. Improving their position requires an active policy of states, including the control of gross capital flow structure.
\end{abstract}

Keywords: Capital Management; Capital Flow; Smile Curve; Subcontractor Role; Second League Economy; Threats of Reshoring; International Value Creation Chain.

\section{Introduction}

Polish economy is threatened with decelerated pace of growth due to depletion of factors that give it a comparative advantage in relation to highly developed economic and trade partners. This may happen because effects of an unfavorable division of labor, which Poland was given in the international value creation chain of goods and services, will emerge. Favorable position occupied in this chain is determined by capital, which gives power to dominant international corporations. Improving this position requires more effective capital management.

Poland, being a small open economy, has achieved significant economic progress in the last quarter of a century, after major systemic transformation. 
High growth rates were facilitated by significant resources of well-educated and cheap workforce, trained for production in the conditions of industrialization, in the process of an ineffective so-called socialist industrialization. Human resources remained available to investors, local and foreign, in a largely urbanized country. It can be added that advantageous geographical location of Poland, in the close vicinity of the core of the European Union, also played a role.

The political transformation at the beginning of the 1990s brought about a radical change in the Polish economy called a ,shock therapy”. In effect of accelerated privatization, part of the "shock therapy”, the basic production plants were taken over by foreign capital due to the lack of domestic capital. Attractive conditions have been created to encourage foreign direct investment (FDI). Foreign investors used this incentive, i.e., above all, cheap labor, transferring labor-intensive production processes to Poland. At times, privatization consisted in the sale of the market segment, where the privatized company concerned was soon closed and the gap in the domestic market was filled by a foreign producer. However, in most cases industrial plants underwent restructuring - they were modernized and became contractor for production commissioned by the new owner. At that stage of development of the Polish economy, however, this brought improved productivity, workforce efficacy and, as a result, benefits to both parties, foreign owners - managers as well as domestic contractors. Therefore, it was offshoring beneficial to both sides.

In the value-creation chain, the company was at the bottom of the value creation chain described as the "smile curve" in which the highest added value margin is obtained by companies located at the beginning and end of the chain.

It works this way because, on both raised edges, the price of the product and the added value is created by the owners of capital, creators of the producer's brand, designers, organizers of the production cooperation chain, those managing this chain, and marketing specialists. Business services are situated be below, including: accounting, financial, legal, logistic, others, and in the middle of the curve i.e. its lowest segment - factory activity rests. Thus the most profitable activity are located at far ends of the curve. I will modestly call them management.

Unfortunately, this management is not a Polish specialty in the international division of labor. This privileged deposit is determined by the ownership of capital and thus the power, and it belongs to the shareholders and subordinate managers managing the corporation, even if the latter are recruited from among domestic residents. As everyone knows, the capital does not have a homeland, while its shareholders have or even more often chose it in tax havens. 
The awakened entrepreneurial activity of the society under the new political conditions, and at the same time a significant inflow of capital, privatization through the purchase of state enterprises by foreign investors and new direct investments from abroad, have resulted in Poland becoming rapidly involved in the process of globalization of the world economy, and achieving clear benefits. However, unfortunately, this also meant becoming exposed to certain restrictions, or even threats that only have become apparent over time.

Globalization and global markets have therefore consolidated both the domestic producers and foreign investors investing in Poland in the same position - a subordinate place in the value creation chain of products and services. These were the roles of a cooperator, subcontractors or contractors of final products commissioned by international corporations. However, this was not at all unfavorable under condition of the Polish economy at the time.

Foreign direct investment contributed significantly to employment growth and labor productivity but they hardly brought any breakthrough in dissemination of new technologies because they were transferring only parts of the production processes. This character of investments is well illustrated by their performance measured by value added by individual industries, in which these investments were located. The effects of foreign direct investment (FDI) measured by the share in the creation of the Gross Domestic Product in Poland were studied by the "Polityka Insight" knowledge platform. Some of these results are presented in Table 1.

Table 1. Share of FDI in selected industries in expenditures and results

\begin{tabular}{|l|c|c|}
\hline & $\begin{array}{c}\text { Industry structure of inflow } \\
\text { of foreign investments (FDI) }\end{array}$ & $\begin{array}{c}\text { Share of industries in GDP } \\
\text { growth thanks to these } \\
\text { investments (FDI) }\end{array}$ \\
\hline Industrial processing & $32 \%$ & $17 \%$ \\
\hline Construction & $4 \%$ & $6 \%$ \\
\hline Trade & $16 \%$ & $19 \%$ \\
\hline Other services & $52 \%$ & $68 \%$ \\
\hline
\end{tabular}

Source: Czerniak and Blauth, 2017.

Although foreign investments brought new technologies to Poland, these were from the area of processing production, bringing relatively small increase in value added in industrial and construction activities, while it was higher in trade and especially in other services. However, a much more important result was their impact on extending export opportunities, which was important for improving the country's balance of payments. 
The opening of the economy to globalization processes also brought new organizational experience in the field of international economic and trade relations ${ }^{1}$ as well as wide access to capital, access to foreign markets and increased exports. The productivity of labor and wages also increased, so the Polish economy shortened the development gap toward more developed countries. In these circumstances the legitimacy of adopting, by Poland, of institutions shaped in Europe is a fact Dani Rodrik finds remarkable (Rodrik, 2011). Reforms carried out and good state finances also enable Poland to meet the criteria for the country's accession to the European Union in 2004. The common EU market has become another major impulse for development. The real convergence process was progressing, additionally strengthened by EU solidarity funds. The global economic crisis of 2008-2009 only slowed down the growth rate, but without stopping the convergence process altogether. Also, the current recovery, or indeed the good economic situation in the world economy, allows to continue this process, although, as it seems, not for long. The role of the subcontractor will inevitably make itself known. The real convergence process will cease. The country may fall into the middle income trap. This term, although widely used to define the situation of a given country, in my opinion is not really appropriate in the case of the Polish economy. It is better to use the terminology of sports: the country remains a permanent player in the lower league of the world economy, with a small chance of promotion to the premier league. Sure it may develop, but it will not reach the level of GDP per capita, and thus also the well-being, of citizens of highly developed countries. The main reason is the lower productivity of work, resulting from less favorable place in the value creation chain (Global Wealth Chain). What we are witnessing is not a good division of labor between equal partners, because the partners involved are not equal. The principle of comparative advantages of David Ricardo cannot be applied here, because the world economy is different than it used to be two centuries ago. This theory postulates that everyone should do what they can do best and the cheapest, whereas in the conditions created by globalization everyone can do the same final product, only different activities are performed in different countries. ${ }^{2}$

1 Rodrik points out that Poland has undergone a similar historical path as other European countries. Imitating institutions that were created in Europe could have been useful in Polish conditions (Rodrik, 2011).

2 For example, the French are promoting fashion of cloths and organize the production, peoples in East Asia weave and sew, and Poles keep the accounts and transport the products. All of them work in this by no means the most modern sector of the economy, but they bring different added value, which results in different remuneration and different levels of participation in generating GDP. 


\section{The Trap or the Second League}

The rate of economic growth in Poland is still higher than in neighboring highly developed countries, and recently it even reaches $4-5 \%$ per year when neighbors record the growth rate only half as high. Facing this, one could ask a question where this fear comes from about the future of the Polish economy to stop the real convergence process. The answer is the fear results from several reasons.

Poland's advance in the economic development means that the risk of the middle income trap is, for the time being, rather unlikely. The level of GDP per capita according to purchasing power parity is slightly more than $50 \%$ of the GDP of the richest neighbor - Germany, and about $70 \%$ of respective level of 19 countries of the "old" European Union. Poland is closer to developed countries than most emerging markets. In the review of world literature on the trap of the medium level of development, Andrzej Wojtyna (2016, p. 8) states that the "definitions of the "trap" can be divided into a qualitative (descriptive) and quantitative nature. In the case of the former, attention is often drawn to the difficulties in shifting countries on the medium level of development up the international value chain. In this approach, the barriers to growth are primarily of a microeconomic nature, and therefore their overcoming requires the use of specific industrial policy tools." Poland may fall in this type of trap, also playing in the lower league of the world economy. In this case, traditional industrial policy, or more broadly - sectoral policy, will no longer suffice. The question then arises whether in the search for a way to counteract such a form of the medium level development trap, one can use the New Structural Economics (NSE) method formulated by J.Y. Lin (Lin and Nowak, 2018). The promotion of sectors with higher added value, in this case, will not bring the desired results, because individual sectors, including those of this type, already exist in the country, but the place of domestic producers in these sectors is unfavorable, subordinate. This is due to the ownership structure and functions of value chain management in individual corporations. It is therefore about using capital management instruments to avoid the dangers of staying permanently in the "second league" of countries advanced in development, condemned to lower labor productivity and thus to a lower margin of value added per employee. This condition is an unfavorable result of much desirable but hasty privatization and of the inflow of FDI, also desired but not always meeting the expectations.

The successful economic development of Poland's trade partners, especially European Union countries, favors the economic growth of countries remaining in the lower league of the European economy. The "smile curve" productivity 
curve can even smoothen towards the straight line, first of all because the share increases in generating GDP of higher-priced services compared to factory operations, in particular business services. They can also grow and indeed increase wages in production and services, both as a result of an increase in the level of qualifications of employees, better technical equipment of jobs, and as a result of the situation on the labor market. The resources of cheap labor are becoming exhausted and here some new threats also arise, as considered further on.

Secondly, small and medium-sized enterprises play major role in the Polish economy, including family businesses. Of course, these enterprises are managed by local entrepreneurs, which should favor higher productivity resulting from the position of property and power. However, the scale of business operations within these enterprises is small, so their productivity is also lower than in the case of companies forming a part of large corporations. The development of such enterprises must, however, face competition in a market dominated by large corporations. If these types of enterprises are not dominated by or bought by the competition, then as a result of their operations the smoothing of the productivity curve will also occur. In turn, all other small and medium-sized enterprises along with the depletion of labor resources will compete with each other for employees, which will also increase labor costs by forcing changes in work organization and investments to increase labor productivity in this sector as well. Such actions will, in the total effect, also contribute to the increase of added value. Unfortunately, such a course of events may turn out to be overly optimistic.

An increase in remuneration is the loss of an important element of competitive advantage. After all, lower labor costs were conducive to transferring laborintensive production processes to Poland and a range of services, including business ones. International corporations can transfer this type of activity further on, to cheaper labor countries. Thus, outsourcing, which served the Polish economy in the previous state of low wages and unemployment, at the beginning of building a market economy, can now become a threat if it leads to deterioration in the bargaining position of employees, or even to unemployment.

Thirdly - for developing countries and for countries much advanced but still playing in the lower league of the world economy, there is unfortunately a new threat resulting from the new industrial revolution called the "Generation Industry 4.0". Although the technological progress associated with this generation is enthusiastically hailed, countries that cannot keep up with the fast pace of high technology can lose a lot. This results not only from the consequences of disappearance of real convergence but may even cause divergence, deepening 
differences in the level of development (Ryć, 2017). Offshoring production processes from countries with high labor costs can turn into reshoring because of the digitization of production, intelligent factories that save human labor and thus its costs. The return of industrial processing to the parent countries of international corporations will cause serious problems for less developed countries. (Götz, 2018)

Therefore, there are enough reasons for countries less advanced in development to make efforts to advance from the second league up to the first.

\section{Managing the Structure of Capital Flow for the Desired Effects on the Microeconomic Scale}

There is a widespread opinion that innovation and entrepreneurship are the way to achieve high productivity. Innovation creates human and social capital, which consists of institutions conducive to innovation. Creating human capital requires financial outlays for scientific research and personnel training. It is also necessary to publicly support the incubation of entrepreneurship and the active role of the state in this field.

The protection of economic development by the state has worked well in history in the case of countries highly developed today. It also passed the exam in many formerly poor economies, especially in East and Southeastern Asia, currently highly developed or significantly advanced in development. This type of protectionism is excluded in the case of Poland - the European Union member state which after the systemic transformation has successfully entered the path of the liberal market economy, although it is exposed to the threat of staying in the status of a subcontractor's country.

The postulate of betting on innovations, their creation, formation of human and social capital is obvious. Capital expenditures for this purpose are justified. However, there is no guarantee that thanks to them, technological capacities that generate high added value will grow in the country. The reason for this are the unfavorable conditions for the "breeding" of champions comparable to those that the free market creates, let alone the common European market. You can only count on isolated cases, because the free flow of capital and the free market are not favorable. This is what J.S. Stiglitz expressed very firmly in his opinion which relates to the emerging market type, but also to Poland (Stiglitz, 2010, p. 258): "Liberalization of trade meant that foreign companies could "slaughter" the local populations in the industry, suppressing the development 
of entrepreneurial talents. When capital flowed freely, the flow of labor was limited - with the exception of the most talented individuals, many of whom found good employment in the global labor market." These sharp words of the Nobel Prize winner also refer to many initiatives and careers of outstanding individuals in Poland. However, they are not an excuse for Polish laments over the outflow of profits abroad from international corporations that have invested in Poland. They have the right to do so and we should remain kind to them for what they have done by creating jobs and for what they leave in Poland in the form of employee wages, usually higher than those in small and mediumsized enterprises, and taxes paid here. This does not mean, however, we should give up protection and not support domestic competitors also using capital resources, including through more effective management of the capital flow structure. Therefore, it is not about changing the rules of the game, but instead about more effective game for the entry of domestic capital into the position of management in an increasing part of important producers and service providers. Developing methods and tools for capital management, including shaping the capital structure at the microeconomic scale supporting industrial policy, seems to be a task that is viable according to the assumptions of the New Structural Economics.

At this point, you can indicate several directions of impact by means of capital.

1. In the first place we should place what almost all researchers consider important, namely the financial outlays for the growth of social and human capital. The point is to educate talented people and to retain the educated ones. To finance research but not to export its results in the raw form, which can be a source of innovation. Therefore, it is not the task of simply increasing the funds for this purpose, but for their well-thought-out structure securing the use of the invested capital. The structure of the funds involved should not only maximize growth, but also minimize the shortage and losses of this capital.

2. The state „breeding” of champions should be approached carefully. What was possible in East Asia cannot be repeated in Central Europe or in the common market. For example, in Poland, focus on electromobility in the passenger car industry without native innovations, has virtually no chance of going beyond the execution and assembly. Technologically advanced components will be purchased abroad even when foreign manufacturers want to manufacture them in Poland. The latter ones are in a favorable position that stems from their property, know-how and power. On the other hand, this does not mean that similar attempts should be abandoned altogether, 
but you also cannot - by the rules of the "old" Structural Economics, which, among others, allowed anti-import production - build on them a favorable position in the value creation chain $^{3}$ (Lin and Nowak, 2018).

3. Control of the capital inflow and outflow structure: support of outsourcing to Poland of innovative projects reporting the demand for qualified, well-paid jobs and business services. However, one should also retain much reserve toward the transfer of simple production if it hardly makes it easier to solve, for example, local problems of the labor market.

4. Domestication of foreign capital by creating favorable conditions for introducing new technologies and reinvesting profits. In truth, today you cannot count on contemporary Wedel, Motels, or Blikle, foreign entrepreneurs and investors who had settled in Poland long ago and have been running their business for generations. Probably due to even greater social mobility, the permanent residence of foreign co-owners or owners is less likely.

5. It is possible to buy out, in whole or by shares in, foreign enterprises operating in the country by private non-public capital. This is not about repolonization, i.e. buy-out by state-owned companies, but first of all about the private sector, along with its strengthening on the capital market.

6. Deepening financial services not only for small and medium enterprises and beginning producers, but also for ambitious capital ventures of Polish producers, both in the country and abroad.

7. Intentional offshoring - Poland was and still is benefiting from the transfer of production of foreign companies to us. Today, we are afraid of their escaping to places with cheaper workforce. However, the offshoring of Polish companies to countries with lower production costs is relatively small. Now and in the future it is necessary to use the offshoring method on a larger scale and to transfer less efficient production beyond the borders of our country. Of course, on condition that this does not cause an increase in unemployment. Such activities of Polish entrepreneurs should gain stronger support.

\section{Conclusion}

The process of reaching a favorable position in the international value creation chain, with the help of an active policy of controlling the flow of capital,

3 The Polish company, which successfully produced buses with electric drive, also successfully exported them, was put up for sale and will probably end up in the hands of foreign investors. 
is by no means certain or even fast. Nonetheless, efforts in this field should be made because the country's staying in this lower league of the world economy is not only unsatisfying to the society but also dangerous. The threat is that of falling into an authentic trap of the medium level of development.

\section{References}

Czerniak, A. and Blauth, K. (2017). Co przyniosty inwestycje zagraniczne. Warsaw: Polityka Insight.

Götz, M. (2018). Przemysł czwartej generacji (przemysł 4.0) a międzynarodowa współpraca gospodarcza. Ekonomista, (4), 385-403.

Lin, J.Y. and Nowak, A.Z. (eds.). (2017). New structural economics for less advanced countries. Warsaw: Wydawnictwo Naukowe Wydziału Zarządzania Uniwersytetu Warszawskiego.

Rodrik, D. (2011). Jedna ekonomia wiele recept. Warsaw: Krytyka Polityczna.

Ryć, K. (2017). The expiring real convergence process under conditions of the common market - how to counteract. In: J.Y. Lin, A.Z. Nowak (eds.), New structural economics for less advanced countries (p. 69-79). Warsaw: Wydawnictwo Naukowe Wydziału Zarządzania Uniwersytetu Warszawskiego.

Stiglitz, J.E. (2010). Freefall. Warsaw: Polskie Towarzystwo Ekonomiczne.

Wojtyna, A. (2016). Standardowe i niestandardowe działania antykryzysowe. Gospodarka Narodowa, (6), 5-22. 
PART TWO 



\section{The Facilitating State and Economic Development: The Role of the State in New Structural Economics ${ }^{1}$}

This paper explores the ideas of development and the role of the state in economic development and institutional change from the New Structural Economics perspective. We argue that economic structures - including the structure of technology and industry, and hard and soft infrastructure - are endogenous to the endowment structure, which is given at any specific time and changeable over time. We advocate a state to facilitate structural change by using industrial policy to overcome market failures in order to help industries with latent comparative advantages to become competitive in the market and the state should pragmatically prioritize the use of its limited resources and implementation capability to create enclaves with favourable infrastructure and institution to jump start a dynamic growth in a country beset with poor infrastructure and institution.

Keywords: Role of the State; Economic Development; New Structural Economics.

\section{Introduction}

After the World War II, many countries gained political independence and started their drive to modernization. In response to the need for nation building in developing countries, a new sub-discipline in modern economics emerged: development economics. It was hoped that development economics would guide developing countries through the process of industrialization and help them achieve prosperity.

However, the results are disappointing. Among nearly 200 developing economies only South Korea and Taiwan, China have moved from low-income to high-income status (Lin and Rosenblatt 2014) ${ }^{2}$ and among the 110 middle-income economies in the 1960 , only 13 moved from middle-income

Published on Man and the Economy, vol. 4(2), December, 2017, pages 1-19.

2 It is likely that mainland China will become the third economy that transformed from low income to high income in around 2025. 
to high-income (Agenor et al 2012). Of those 13 economies, eight were either countries surrounding Western Europe, whose gaps with developed countries were small to begin with, or oil-producing countries. The other five were Japan, Korea, Taiwan, Hong Kong, and Singapore.

The seminal Solow growth model predicts convergence in income as poor countries should grow faster than rich countries due to diminishing returns to capital (Solow 1956). However, despite both the efforts made by developing countries and the assistance of many multilateral development agencies, most developing economies failed to catch up with the high-income economies. This phenomenon is puzzling.

Mankiw et al (1992) argues that an augmented Solow model that includes accumulation of human as well as physical capital provides an excellent description of the cross-country data. Following a similar principle to that applied to physical capital, lower levels of human capital should mean a higher rate of return. However, poor countries are unable to accumulate enough human capital due to lack of investment in high quality education and also because there were significant brain-drain problems. This is similar problem to that of the capital flight from poor countries to rich counties (Lucas 1990). Thus lower physical capital and human capital are the results of something more fundamental that is at the root of the growth failures.

The nature of modern income growth is, as Kuznets (1966) argues, a process of continuous structural transformation with continuous technological innovation in existing industrial and emergence of new higher value-added industries, which raise labor productivity, and improvement in hard (tangible) infrastructure and soft (intangible) infrastructure (institution), which reduce transaction costs in the economy. As developing countries are relatively backward in terms of technology and industries they should have the potential to grow faster than developed countries and achieve convergence as result of the ease of improving their technology and upgrading their industries (Gerschenkron 1962). However, most developing countries have not benefited from this potential and have been trapped in low-income or middle-income status since WWII.

It has been argued that efficient institutions are the key to growth, and that the development of efficient economic institution in Western Europe accounts for the rise of the West (i.e. North and Thomas 1976, North 1990, Acemoglu and Robinson 2012). It is also widely agreed that institutions are persistent and it is unlikely that bad institutions in a country will improve spontaneously (North 1990; Acemoglu et al 2001). 
Countries with better institutions, more secure property rights, and less distortionary policies will invest more in physical and human capital, and will use these factors more efficiently to achieve a greater level of income (Acemoglu et al 2001). However, for countries that happen to have bad institutions that hamper economic growth, is there a way they can improve their institutions and develop their economies other than going back in time to change history?

As Keynes (1935, p. 384) said, "It is ideas, not vested interests, which are dangerous for good or evil". In this paper we will argue that the poor development performances in most developing countries are the result of inappropriate ideas about development and the role of the state. This paper explores the ideas of development and the role of the state in economic development and institutional change from the New Structural Economics (Lin 2011; 2012) perspective.

We argue that the state facilitates economic development by overcoming the inherent market failures in technological change, industrial upgrading and improvements of hard and soft infrastructure. These failures arise from various externalities, associated with first movers, and coordination problems, arising from improvement of hard infrastructure and institutions, in the process of structural transformation.

In our view the dynamic growth of an economy requires an organic relationship between the market and the state as follows: the market is efficient only if the state plays a facilitating role to overcome the inherent market failures and the goal of the state's facilitation is to ensure that the market is efficient. We also argue that, if there are right ideas, the state, no matter whether it be strong or weak, in a developing country could adopt and implement policies pragmatically to jump start a dynamic growth even though the country is beset with poor infrastructure and institutions. We are not arguing for more government controls over the market or more interventions in the market. What we argue here is that a facilitating state is a necessary condition for development. With right ideas it is possible for a developing country to start and sustain dynamic economic growth.

This paper aims to develop a new theory of facilitating states in economic development. It first reviews the previous ideas of development economics, with a focus on their view of the role of the state. Then present the main ideas of New Structural Economics and discusses the role of the state from the perspective of New Structural Economics. 


\section{Previous Generations of Development Economics ${ }^{3}$}

\subsection{Development Economics 1.0: Structuralism}

The first generation of development economists was Structuralists. After WWII, many developing countries shared a common aspiration for their people to enjoy the same living standard as citizens in the developed world. To achieve that goal, it was necessary for a developing country to have the same income and labor productivity as the developed countries; which in turn required having the same advanced industries as the developed countries. Whereas the reality was the developing economies were dominated by traditional agriculture and natural resource exploitation.

The desire to develop advanced industries in developing countries was also influenced strongly by the deterioration in the terms of trade between primary commodities and industrial products in the 1930s and 1940s during the Great Depression. The political leaders and social elites in many Latin American countries believed that the decline in the terms of trade against the export of primary commodities was secular and led to the transfer of income from resource-abundant developing countries to capital-abundant developed countries. They argued that the way for a developing country to avoid being exploited by developed countries was to develop domestic manufacturing industries through a process known as import substitution. Moreover, the emergence of previous colonies or semi-colonies as newly independent states in Asia and the Middle East, and later in Africa, was accompanied by strong nationalist sentiments.

According to Structuralism, developing countries could not develop advanced industries because they were beset with structural rigidities, causing market failures and inhibiting them develop advanced modern industries spontaneously. Structuralism advocates a developmental state, advising the governments of developing countries to adopt the import-substitution strategy with various price distortions and direct government mobilization and allocation of resources to develop advanced modern industries. This approach was also supported by the prevailing interventionist Keynesian economics at that time.

3 This section draws on Lin (2011) and Lin and Rosenblatt (2012). 
With the import-substitution strategy, many developing countries enjoyed a period of investment-led growth, but subsequently encountered stagnation and frequent crises. The income gap between developed and developing countries widened.

\subsection{Development Economics 2.0: Neoliberalism}

As government-led economic development strategies based on structuralism failed in many countries, the free market doctrine appeared to triumph and influence development thinking. The prevailing Keynesian macroeconomics was also challenged by the stagflation in the 1970s, the Latin American debt crisis, and the collapse of the socialist planning system in the 1980s. The so-called "rational expectations revolution" emerged and refuted the structuralist theoretical foundation for the state's role in using fiscal and monetary policy for economic development.

Neoliberalism emerged subsequently in the 1980s. It viewed government interventions as the main reason for the failure of developing countries to catch up with developed countries and recommended a set of neoliberal policies, encapsulated in the Washington Consensus, to overcome government failures by eliminating the interventions (Williamson 1990).

Neoliberalism promotes economic liberalization, privatization, and advocates a minimal state, advising developing countries to institute well-functioning market institutions similar to those in developed countries and believing that dynamic growth and structural transformation will happen spontaneously once there is a well-functioning market.

Under the guidance of Washington Consensus, many developing countries adopted a "shock therapy" to implement structural adjustment programs in the 1980s and 1990s for removing government interventions and distortions with policy advice and funding supports from International development institutions, like the World Bank and International Monetary Fund. The intention of structural adjustments was good, and the economic analysis of those programs appeared solid and convincing. However, the result was disappointing. The growth rate in the 1980s and 1990s was lower than that in the 1960s and 1970s, and the frequency of crises was even higher. Many developing countries experienced lost decades, with the income gap between developed and developing countries widening further (Easterly 2001). 


\section{A New Generation of Development Economics}

\subsection{New Structural Economics}

According to the World Bank's 2008 the Growth Report (Commission on Growth and Development 2008), after WWII there were 13 economies that achieved an outstanding performance of growing on average at seven percent or more continuously for 25 or more years. These 13 economies had the following five characteristics: (1) They were open economies; (2) They maintained macroeconomic stability; (3) They had high savings and high investment rates; (4) They had a well-functioning market mechanism, or were moving towards a market economy; (5) They all had credible, committed, and pro-active governments.

Michael Spence, the chairman of the Commission on Growth and Development, stresses that those five characteristics are ingredients of success but not a recipe for success. We argue that what is needed is a new development economics that is able to provide a consistent logic that encompasses the five characteristics of successful developing economics. In addition, we need to provide practical guidelines that developing country governments could follow.

The third generation of development proposed by Lin (2011 and 2012) labelled the New Structural Economics is an application of the neoclassical approach to study the determinants of economic structure, structural change and their impact on the evolution of development. As Rodrik (2011) explains “...developing countries are qualitatively different from developed ones. They are not just radially shrunk versions of rich countries. In order to understand the challenges of under-development, you have to understand how the structure of employment and production - in particular the large gaps between the social marginal products of labor in traditional versus modern activities - is determined and how the obstacles that block structural transformation can be overcome."

The main argument of New Structural Economics is that economic structures, including the structure of technology and industry, which determines labor productivity, and hard and soft infrastructure, which determines transaction costs, are endogenous to the endowment structure, which is given at any specific time and changeable over time.

Endowments and the endowment structure determine the economy's total budgets and relative factor prices at any specific time. These in turn determine the economy's comparative advantage and optimal industrial structure. That is, when the industrial structure is consistent with comparative advantage, as determined by the endowment structure, such a structure will have the lowest 
factor costs of production in domestic and international markets. Therefore, as an economy's structure of factor endowments evolves from one level of development to another, the optimal industrial structure of the given economy will evolve accordingly.

Income growth depends on upgrading the industrial structure to increase labor productivity, which in turn depends on the upgrading of the endowment structure, moving from labor intensive to capital intensive industries. With the upgrading of industrial structure, improvements in "hard" and "soft" infrastructure are required to reduce transaction costs and risks.

Following comparative advantage (determined by the endowment structure) to develop industries is the best way to achieve dynamic growth and convergence. The economy with such industries and appropriate hard and soft infrastructure will be most competitive, produce the largest surplus, have the highest possible returns to capital and thus savings, ensure the fastest upgrading of the endowment structure, and achieve the most rapid industrial upgrading and income growth (Ju, Lin and Wang 2015). In this process, a developing country can have latecomer advantages and thus have a faster technological innovation and industrial upgrading than high-income countries, which leads to faster growth and convergence with high-income countries.

For the entrepreneurs, what they care about is profitability. How to translate the concept of following a country's comparative advantages to influence the spontaneous choice of entrepreneurs? This requires a well-functioning market so that the relative factor prices reflect the relative supply of factors in the endowments. With such relative factor prices, entrepreneurs for their own profitability and competitiveness in the market will enter industries and adopt technologies which are consistent with the comparative advantage determined by factor endowments.

But economic development is a dynamic process. It's a process of continuous technological innovation and industrial upgrading. Such upgrading and improvements require first movers. Two market failure issues arise during that process. One is the externality, i.e. the government needs to provide incentives for the first mover. And the second is coordination for improving institutions and infrastructure, which affect transaction costs and the first movers' probability of success. Thus, in addition to an effective market mechanism, the government should play an active role in facilitating structural change.

Those two conditions of efficient markets and facilitating state are precisely the stylized facts 4 and 5 of the Growth Report. If a country follows its comparative advantage in their development, it will open its economy to the world market (fact 1) and achieve macroeconomic stability due to its 
competitiveness (fact 2). Following comparative advantages will generate the largest surplus and highest incentives for savings and investments (fact 3). So following comparative advantage is a prescription for development success (Lin 2012, chapter 2).

From the perspective of New Structural Economics, Structuralism failed because it ignored the endogeneity of economic structure of a country and recommended promotion of certain industries that were too advanced for the country's level of development and defied the comparative advantages of that country. The firms were non-viable in open competitive markets and required government subsidies and protection for their initial investment and continuous operations. This led to a misallocation of resources, rent-seeking, corruption, and political capture. The successful East Asian economies instead adopted an export-oriented development strategy to develop labor-intensive manufacturing, exploiting the comparative advantages determined by their abundant labor supplies in the 1950s and 1960s. This later strategy was not one that was recommended by Structuralists.

The Washington Consensus, based on Neoliberalism, failed because it ignored the fact that the distortions in developing countries were designed to protect nonviable firms in the priority sectors (due to the previous comparative advantage-defying strategy) and advised governments to eliminate all distortions immediately, causing the collapse of old priority sectors and deindustrialization. The Washington Consensus also opposed the government adopting a sectortargeted policy to provide externality compensation incentives and overcome coordination failures by improving necessary hard and soft infrastructure to facilitate a firm's entry into sectors consistent with the country's comparative advantage.

For transition economies, which achieved stability and dynamic growth during their transition processes, such as China, Vietnam and Cambodia in the 1980s and Mauritius in the 1970s, their governments adopted a pragmatic dualtrack approach: on the one hand, providing continuously transitional support to nonviable firms in the old priority sectors and removing distortions only when firms in those sectors became viable or the sectors become very small, and on the other hand, their governments facilitated private firms' entry into sectors that were consistent with the country's comparative advantage, which was previously repressed before the transition. The latter can be achieved by setting up special economic zones/industrial parks to overcome infrastructure constraints; ${ }^{4}$ providing one-stop service to improve the business environment;

4 Most special economic zones in many countries fail because of failures in infrastructure and/ or lack of effective regulations and regulation implementation, or because the zones had 
and engaging in active investment promotion to attract foreign firms' investment in these countries as part of their global value chains. They would thus gain access to the global market (Lin 2013).

Such a strategy contributed to stability and dynamic growth and is favorable to domestic capital mobilization and FDI. Ironically, the dual track approach was viewed as the worst transition approach from the Neoliberal point of view (Murphy, Shleifer and Vishny 1992).

\subsection{Barriers to Development and Industrial Policies}

New Structural Economics argues that the state has an essential role in facilitating rapid technological innovation, industrial upgrading and diversification because of the need to address externalities and solve coordination problems in the improvement of infrastructure and institutions. Industrial policy is a useful instrument for a state to facilitate structural transformation. This is because the required coordination for improvements in infrastructure and institutions may differ among industries and locations, and the government's resources and capacity are limited so the government needs to use them strategically. ${ }^{5}$

However, for an industrial policy to be successful, it should target sectors that conform to the economy's latent comparative advantage. The latent comparative advantage refers to an industry that has competitive, low factor costs of production internationally, i.e., consistent with the country's comparative advantage determined by its factor endowments, but the transaction costs are too high, due to inadequate hard and soft infrastructure, to be competitive in domestic and international markets.

Firms in an industry with latent comparative advantages will be viable and the sectors can be competitive once the government helps the firms overcome coordination and externality issues in the improvement of hard and soft infrastructure to reduce transaction costs and risks. But how can the government pick the sectors that are in line with the economy's latent comparative advantages? Depending on a targeted industry's distance to the global technology frontier, New Structural Economics classify industries in a developing country, especially a high-middle income country like China, into five categories and recommends government's facilitation according to their respective needs for growth (Lin 2017):

been located in the wrong place due perhaps to political motivation, or because the zones target industries were not ones in which the country had a comparative advantage.

5 See Aghion and Rouglet (2014) and Aghion et al (2015) for more discussion on the role of the state and industrial policy. 
(1) For industries that a country still has a distance to the global technology frontier, the government should find out the binding constraints in infrastructure, financing, human capital, etc., for their catching up and help to remove them.

(2) For industries that a country is already on the global frontier, the government should support firms to do R\&Ds to maintain the industry's technological leadership globally.

(3) For industries that have already lost their comparative advantage, such as labor-intensive industries in China, the government should help firms either to shift to branding, product designs and marketing management, of which the returns are high, or relocate to countries with low wages.

(4) For short innovation-cycle industries, which rely more on human capital than physical capital, countries with abundant human capital, and especially like China also with its own large domestic market, the government can set up incubation parks, encourage venture capitals and protect intellectual property to facilitate innovations.

(5) For industries that are strategically important for national defense but the country does not have comparative advantage, the government should subsidize them directly with fiscal expenditure instead of price distortions and other market interventions.

\section{The Facilitating State, Political Leaders and Ideas}

\subsection{Road to Development}

A developing country is likely to be beset with not only low productivity industries and poor infrastructure but also backward, grabbing or distorted institutions. Institutions shape the incentives of a society. New Institutional Economics believe that a country will have dynamic growth and become rich if it has good institutions to provide incentives for work, accumulate human and physical capital, acquire better technology and improve resource allocation (North and Thomas 1973; North 1981, 1990). If a country has poor institutions-which deprive people of the incentives to do the right thing for economic growth -it will be poor and will stagnate. For example, Acemoglu et al (2001) and Acemoglu and Robinson (2012) argue that United Kingdom and the United States are rich because they have inclusive institutions that limited the power of the elites and created a society in which political rights are 
widely distributed. Latin America and Africa are poor because of the extractive institutions.

In addition to arguing that institutions matter, New Institutional Economics also claims that institutions are endogenous, and are determined by other social, economic and political factors in the economy (North 1981; North and Thomas1973). Moreover, institutions that existed hundreds of years ago still have an important impact on the current institutions and level of economic development, because institutions are determined also by culture and history, and thus institutional change is path dependent (Acemoglu et al 2001, North 1981).

Following the above logic, the backwardness of institutions explains why poor countries are poor and why they have failed to develop. As such, the state and people are powerless because institutions cannot be exogenously changed. If the line of reasoning by the New Institutional Economics is accepted, the study of development would be a very dismal subject, as it cannot put forward any solution to the development problem.

A quick observation of the economies in the East Asian Miracle (World Bank 1993) and the 13 successful economies in the report of Commission of Growth and Development (2008) show the following common features: in spite of being trapped in poverty and beset with bad institutions previously, they all had committed, credible and capable government and the state adopted the rule of law and other regulations that are consistent with modern economic growth and policies to pursue an export-oriented strategy exploiting the comparative advantages based on their development stages. ${ }^{6}$ Therefore, it is possible to break the grip of bad institutions if the state plays an appropriate function.

However, looking back at the economic growth of the world, it is not difficult to see that the majority of the poor countries did not governments that had the right idea of how to develop and provide a sufficiently productive business environment and efficient public services (Besley and Persson 2009, Bardhan 2016).

In any development stage, the state has to play a proactive, facilitating role. The constraints on economic development that the state needs to remove will be different for different countries and for a country in a different development stage. In the early stage of development in a country, the constraints are likely

6 It should be noted that many other countries also introduced the rule of law and other regulations but failed to achieve modern economic growth. The key here is not whether the rule of law is introduced but that it is accompanied with a development strategy to promote industrial development in line with a country's comparative advantage. This will be discussed later. 
to be poor infrastructure, low skills, bad business environment, and backward institutions, and additionally various distortions and interventions if the country is on a transition process from a structuralist development strategy to marketoriented economy. For a developed country, the constraints are most likely to be the breakthrough in basic science required for the development of new technology/products or laborers' skill for working in new industries. If an efficient institution and a productive business environment cannot evolve spontaneously and infrastructure cannot be provided by the private sector, the state is needed to induce and develop them to facilitate the growth of the economy.

\subsection{The Role of Political Leaders}

Political leaders operate the government. If we want to analyze the quality of a government's policies and regulations, we need to understand what motivates the political leaders to determine government policies (Lin, 1989). In any system, a political leader's personal interest is to 1) stay in power and 2) to leave a legacy and have a good name in history if staying in power is not under challenge (Lin 2009). The best way to stay in power and to have a good legacy in history is to bring prosperity to the nation. In this way, the political leader will be supported by the people and have a good name in history. However, when the ideas the political leader follows and the policies do not bring prosperity to the nation, the political leader may lose the support of the people and his leadership may be challenged. For the purpose of staying in power, the political leader may create supporting vested-interest groups by patronage to consolidate his/her control at further costs of prosperity in the nation. There will be a vicious cycle. Therefore, an expropriating state and grabbing elites are the likely consequences of the political leader's inability to bring prosperity to a nation.

Although a political leader has to follow certain conventions and are also constrained by either the elites or the people who put him/her in power, a political leader can use his/her discretionary power to make many things happen. The key for success in a developing country with poor infrastructure and institutions is for the leader of the country to use his/her discretionary power to generate quick wins to jumpstart modern economic growth by creating enclaves such as special economic zone, which have good infrastructure and business environment, to turn industries of the country's latent comparative advantages into competitive advantages. Such quick wins will generate a virtuous cycle by generating more resources for expanding infrastructure and business environment improvements to other parts of the nation. The quick 
wins will also enhance the political leader's authority for making more desirable institutional changes. With dynamic growth, a new entrepreneurial class will arise and the power of old vested-interests elite will decline. Therefore, this pragmatic approach can be used to break the institutional deadlock in a country beset with grabbing-hand vested interests politics, bad institutions or excessive distortions and interventions inherited from the past (Lin and Monga 2017).

Park Chung-hee in South Korea, Chiang Kai-shek in Taiwan, China, Lee Kuan Yew in Singapore in the 1960s and Deng Xiaoping in mainland China since 1979 played an instrumental role in jump-starting the development process that transformed their economies even though their economies like those in other developing countries were trapped in poverty and beset with poor infrastructure and bad or distorted institutions before starting the dynamic transformation. There has been some empirical literature showing that changes in the national leader can matter significantly for economic growth. Jones and Olken (2005) find that leadership transitions are associated with shifts in country growth rates.

Even for a political leader who inherits an expropriating state and grabbing elites, if there is a theory for bringing inclusive and dynamic growth quickly, they will have the incentive to use their discretionary power to follow it, probably in a pragmatic process, in which the vested interests are protected to maintain political/social stability and a new niche of growth is ignited such as in the dualtrack transition in Mauritius in the 1970s and China and Vietnam in the 1980s, to generate a virtuous cycle of growth. ${ }^{7}$

\subsection{Right Ideas and Appropriate Development Strategies}

In pursuing modernisation, political leaders in developing countries adopted certain strategies - which consisted of a set of policies, including various interventions and regulations - as a vehicle to achieve their goals. The set of policies shaped the development and quality of institutions in their countries, which in turn affected their economic performance (Lin 2009). Due to the complex nature of modernization in a developing country and the political leaders' bounded rationality in understanding the subject, it was practical for political leaders to follow the dominant social thought in the pursuit of national development. It was the dominant social thought that shaped the institutional order of developing countries.

7 See Chapter 2 of Lin (2009) and Lin and Monga (2017) for more detailed discussion. 
Unfortunately, the dominant social thought about achieving modernisation was based on incorrect perceptions of the root causes for and constraints on a developing country's modernisation. Many of the strategies were under the influence of the previous generations of the development economics which has misled many of the leaders and economic policies of these countries. They not only failed to deliver the promise of making their countries as successful as developed countries, but also caused stagnations, frequent crises and even disastrous consequences in their economies (Lin 2009). Only few economies escaped the influences of the dominant social thought at that time, such as the East Asian tigers in the 1960s and China in the 1980s. The leaders of these governments were not influenced by the dominant social thought at that time but adopted a pragmatic approach during the transformation process. ${ }^{8}$

Frictionless transactions, complete information and clearly defined property rights are desirable but do not normally exist in real world, especially developing economies. The government of a developing country may try to impose developed country's style of institutions with an attempt to improve the factor market and the product market efficiency, enhance the transparency of the information, reduce the friction in transactions and so on, but such institutional changes are difficult to achieve as institutions tend to be persistent and path-dependent. Without an endogenous force for change, the imposed institutions may not function as intended (Lin 1989). Thus it is necessary to understand and solve the development problem from the endowment structure of the economy, including its institution, rather than starting from the efficient market assumptions of the neo-classical economics.

Low-income countries are often beset with backward or distorted institutions. The issue is not whether they have an effective or strong state to overcome the institutional barriers but how the political leader uses their discretionary power to jump-start development. The difference between New Structural Economics and other development thinking is as follows: The New Structural Economics advocates a developing country should look at what it can do well based on what it has now and create conditions to scale up what it can do well, instead of looking at what it does not have or cannot do well based on what the highincome countries have and can do well and try to have or do as the high-income countries do.

The key point here is that the state has to follow a right strategy in a pragmatic way, to best utilize the resources in the economy and to create incentives for individual and private firms to pursue economic activities that

8 See Buera and Shin (2010) for a discussion of how social thought has significant impact on the economic growth of a country. 
will increase the income level of the country. A right approach guided by a right idea is more important than a strong state recommended by some economists. If the development strategy is wrong, a strong state may cause more harm to its people and country than a weak state. Therefore, a strong state is a two-edge sword, as argued by North (1981, p. 20).

In other words, in order to jump start the development process and sustain it, there must be a facilitating state that is able to provide basic public infrastructure and to help the latent comparative advantage industries become competitive by improving infrastructure and institutions. Even in a state with limited capacity and resources, an inheritance of poor institutions, and beset with vested-interested group politics, it is still possible for the political leader, if he/she has the right ideas, to use his/her discretionary power and resources to create enclaves, such as special economic zones and industrial parks, with good infrastructure and one-stop service, to jump-start a dynamic growth in a Pareto improving manner.

The dynamic growth, even starting in small enclaves, will give the hope to the people, enhance the political strength of the leader, and generate more resources for further changes in the economy. It is just like the best performing African country Mauritius' transition in the 1970s. It inherited a Western multiple-party democracy, a monoculture in sugar, distorted institutions due to the structuralist import-substitution strategy and did not have a strong state, but it has achieved significant growth in both living standard and the state capacity by starting its transition from an textile and garments export processing zone in the 1970 (Subramanian and Roy 2003). Its per capita GDP reached USD 9,628 in 2016. This is also how China, Vietnam and a few other East Asian countries are able to grow dynamically, even though their institutions were very poor and are still poor measured by many macroeconomic indicators including Doing Business Indicators and Corruption Perception Index.

On the contrary, if the idea for development is wrong, for example the structuralism for development and neoliberalism for transition, even a country with a strong state capacity, such as Soviet Union, bountiful resources, such as Argentina and many other Latin America countries, or with a good institution at the beginning such as the Philippines, India and other post-colonial developing countries, the development performance will be poor. Therefore, the fundamental determinant for development success or failure in any country under any preconditions is ideas. ${ }^{9}$

$\overline{9}$ See Lin (2009) and Lin and Monga (2017), for some detailed arguments along these lines 


\section{Conclusions}

The mainstream in economics has been dominated by the Neoclassic Economics since the Second World War, but the role of the state is missing in it. Many other forms of development economics have government playing various roles but they have proven unsatisfactory.

Structuralism advocates a developmental state and is usually pursuing ambitious industrialization against comparative advantages. The goal was to build up advanced modern industries and use the government's protection and subsidies as policy instruments. Neoliberalism advocates a minimal state and opposes the use of industrial policy. Its goal is to build up a well-functioning market institutions, and it believes structural change will happen spontaneously in a well-functioning market.

Neoclassical economics address the problem of efficient markets; New Institutional Economics provides a theory of the role of the institutions and illustrates the importance of the institution. The New Structural Economics argues that the state matters and the right idea matters. It explains and shows how to achieve the optimal development results with a given endowment structure, with the government's proactive policy. New Structural Economics puts the state and strategy of development and transition right in the center of the new generation of developmental economics.

This paper focuses at the role of the state from the new structural economics point view. New Structural Economics advocates a facilitating state. Its role is to facilitate structural change by using industrial policy to overcome market failures in order to help industries with latent comparative advantages to become competitive advantages in the market and a pragmatic, gradual, dual-track approach for transition to achieve stability and dynamic growth.

This paper provides guidance as to how governments should direct the economy and emphasizes that government should promote the economy in a way that is consistent with its comparative advantage. This paper also develops a theory of facilitating states and argues that the conventional literature missed an important role of the state: inducing institutional change and facilitating economic development.

A less developed country is associated with low physical capital accumulation, low human capital level, poor infrastructure and backward or distorted institutions, which are the barriers to development. We argue that political leaders can play crucial roles in shaping the growth of nations. However, this is not about strong or weak state. Political leadership and pragmatism are essential for jump-starting development in developing countries. 
If the idea is right, even if the state in weak at the beginning it is still possible for the state to create enclaves, such as special economic zones, to help industries of the country's latent comparative advantage to quickly become the country's actual competitive advantage, and start a virtuous cycle of development. If the idea is wrong, for example China's heavy industry oriented development strategy before the transition in 1979 and the shock therapy in Russia's transition in the 1990s. Those ideas resulted in slow income growth and low levels of economic development.

This paper argues for a proactive role of the state. We recognize that the government failure prevail in history and many parts of the world today. Lewis (1955, p. 376) observes: "No country has made economic progress without positive stimulus from intelligent governments. ... On the other hand, there are so many examples of the mischiefs done to economic life by governments." However, Stiglitz (2011) is right to argue that interventions will never be perfect, the choice is between imperfect governments and imperfect markets, each of which has to serve as a check on the other; they need to be seen as complementary, and we need to seek a balance between the two - a balance which is not just a matter of assigning certain tasks to one, and others to the other, but rather designing systems where they interact effectively.

To reduce the chance of inappropriate interventions and increase the probability of success, the New Structural Economics advocate an organic relation between the market and the state in which "the market is efficient only if the state plays a facilitating role to overcome the inherent market failures and the end of the state's facilitation is to ensure the market to be efficient". The New Structural Economics also advocate that the state should pragmatically prioritize the use of its limited resources and implementation capability to overcome constraints for scaling up industries in which the country has a latent comparative advantage (what they can do well), based on the country's existing endowments (what they have now). If the political leader in a developing country can follow such advice, any developing country can jump start a dynamic growth path for inclusive and sustainable development even though the country may be trapped in poverty for centuries and be beset with poor infrastructure, bad institutions and vested-interest politics.

\section{References}

Acemoglu, D., Johnson, S. and Robinson, S. (2001). The Colonial Origins of Comparative Development: an Empirical Investigation. American Economic Review, 91(5), 1369-1401. 
Acemoglu, D. and Robinson, J.A. (2012). Why Nations Fail: The Origins of Power, Prosperity, and Poverty. New York: Random House, Crown Business.

Agenor, P.R., Canuto, O. and Jelenic, M. (2012). Avoiding Middle-income Growth Traps. Economic Premise, 98. World Bank.

Aghion, P., Cai, J., Dewatripont, M., Du, L., Harrison A. and Legros, P. (2015). Industrial Policy and Competition. American Economic Journal: Macroeconomics, 7(4), 1-32.

Aghion, P. and Roulet, A. (2014). Growth and the Smart State. Annual Review of Economics, $6(1), 913-926$.

Bardhan, P. (2016). State and Development: The Need for a Reappraisal of the Current Literature. Journal of Economic Literature, 54(3), 862-892.

Buera, F.J. and Shin, Y. (2010). Financial Frictions and the Persistence of History: A Quantitative Exploration. Journal of Political Economy, 121(2), 221-272.

Commission on Growth Development. (2008). The Growth Report: Strategies for Sustained Growth and Inclusive Development. Commission on Growth and Development Final Report. Washington, DC: World Bank.

Easterly, W. (2001). The Lost Decades: Explaining Developing Countries' Stagnation in Spite of Policy Reform 1980-1998. Journal of Economic Growth, 6(2), 135-157.

Jones, B. and Olken, B. (2005). Do Leaders Matter? National Leadership and Growth Since World War II. Quarterly Journal of Economics, 120(3), 835-864.

Ju, J., Lin, J.Y. and Wang, Y. (2015). Endowment Structures, Industrial Dynamics, and Economic Growth. Journal of Monetary Economics, 76, 244-263.

Keynes, J.M. (1935) [1964]. The General Theory of Employment, Interest, and Money (first Harbinger edition). New York, Chicago, Burlingame: Harcourt, Brace and World.

Kuznets, S. (1966). Modern Economic Growth: Rate, Structure, and Spread. New Haven, CT: Yale University Press.

Lewis, A. (1966). Theory of Economic Growth. London: Allen and Unwin.

Lin, J.Y. (1989). An Economic Theory of Institution Change: Induced and Imposed Change. Cato Journal, 9(1), 1-33.

Lin, J.Y. (2009). Economic Development and Transition: Thought, Strategy and Viability. Cambridge, UK: Cambridge University Press.

Lin, J.Y. (2012). New Structural Economics: A Framework for Rethinking Development and Policy. Washington DC: the World Bank.

Lin, J.Y. (2013). Demystifying the Chinese Economy. The Australian Economic Review, 46(30), 259-268.

Lin, J.Y. (2017). Industrial Policies for Avoiding the Middle-income Trap: a New Structural Economics Perspective. Journal of Chinese Economic and Business Studies, 15(1), 5-18.

Lin, J.Y. and Monga, C. (2017). Beating the Odds: Jump-starting Developing Countries. Princeton, NJ: Princeton University Press.

Lin, J.Y. and Rosenblatt, D. (2012). Shifting Pattern of Economic Growth and Rethinking Development. Journal of Economic Policy Reform, 15(3), 171-194.

Lucas, R.E., Jr. (1990). Why Doesn't Capital Flow from Rich to Poor Countries? American Economic Review, 80(2), 92-96.

Mankiw, G., Romer, D. and Weil, D.N. (1992). A Contribution to the Empirics of Economic Growth. The Quarterly Journal of Economics, 107(2), 407-437.

Murphy, K.M., Shleifer, A. and Vishney, R.W. (1992). The Transition to a Market Economy: Pitfalls of Partial Reform. Quarterly Journal of Economics, 107(3), 889-906.

North, D.C. (1981). Structure and Change in Economic History. New York: W.W. Norton \& Co. 
North, D.C. and Thomas, R.P. (1976). The Rise of the Western World: A New Economic History. Cambridge: Cambridge University Press.

North, D.C., Wallis, J.J. and Weingast, B.R. (2009). Violence and Social Orders: a Conceptual Framework for Interpreting Recorded Human History. Cambridge University Press.

North, D.C. and Weingast, B.R. (2000). Introduction: Institutional analysis and economic history. The Journal of Economic History, 60(02), 414-417.

Rodrik, D. (2006). Goodbye Washington Consensus, hello Washington Confusion? A Review of the World Bank's Economic Growth in the 1990s: Learning from a Decade of Reform. Journal of Economic Literature, 44(4), 973-987.

Solow, R. (1956). A Contribution to the Theory of Economic Growth. Quarterly Journal of Economics, LXX, 65-94.

Williamson, J. (1990). What Washington Means by Policy Reform. In: J. Williamson (ed.), Latin American Adjustment: How Much Has Happened? Washington: Institute for International Economics.

World Bank. (1993). The East Asian Miracle: Economic Growth and Public Policy. Oxford, UK: Oxford University Press. 


\section{The Use of the New Structural Economics for Modernization and Increasing the Innovativeness of the Polish Economy}

Ultimately, the deciding factor for Poland's modernization success will be the pro-modernization attitude of business entities, employees, and consumers (hence, the whole society). The New Structural Economics Apparatus can be helpful in strengthening the role of the state in meeting the challenges the Polish economy is facing, but we must be aware that the application of NSE may face many serious challenges and limitations. First of all, large companies essential to create an innovative development coalition are either owned by foreign corporations or remain state property. Secondly, few Polish small and medium-sized enterprises have grown enough to be able to undertake the effort of global competition. Thirdly, the society, including business entities, is suspicious of state institutions, and the state is very distrustful about public-private projects. Fourthly and finally, Poles after years of scarcity want to consume rather than save, thus they are hardly prone to promises to improve the future standard of living in exchange for disciplined serving the interests of the state and corporations.

Keywords: Modernization; Innovations; The Role of the State; Usefulness of NSE.

\section{Introduction}

Thousands of articles and books on enterprise innovation have been written in recent decades. Schumpeter's theories have moved from the margins to the mainstream of economic considerations. In this context, the role of the state is presented as an activity supporting initiatives of business entities and scholars in the frame of the knowledge economy.

The New Structural Economics (NSE) differently distributes the accents of interdependence between the state and the economy entities - enterprises and households (or, in the nomenclature of the production function: between capital and labor). In the following part we try to show to which extent this 
approach is better adapted to the challenges facing the economies trying to catch up with developed countries, including the Polish economy as a small open economy, and to which extent this approach may face inherent difficulties.

As we have shown elsewhere, NSE recommendations cannot be directly transferred to Polish conditions. It results first of all from different long-term cultural conditions - the lack of an analogy for the tradition of social relations built on the basis of Confucianism (Jędrzejczak and Sterniczuk, 2017). An additional limitation are Poland's commitments in the legal and institutional connections of the European Union which restrict the accessibility of certain economic policy mechanisms, e.g. due to the prohibition of subsidizing companies and the requirement to comply with product, environmental, and working conditions.

However, this doesn't mean that the NSE rules and experience are unusable altogether. We see three dimensions of its use, adapted to the specific realities and challenges of the economic modernization of Poland:

1) reformulating the economic paradigm,

2) formulating and conducting economic policy,

3) participation in the global economy.

In the following part, we will discuss in more detail these three dimensions of possible application of NSE in the undertaking of Polish modernization challenges.

\section{Reformulating the Economy Paradigm}

The concept of a paradigm - the assumptions for thinking about the economy - does not seem to have much to do with the effective use of NSE in solving the problems of innovative modernization of the Polish economy A.D. 2018. And yet, quite the opposite holds true. It should be observed that the paradigm of the market economy, as we know from the theory of economics, is a product of the nineteenth Century with an admixture of legitimacy for the government's actions observed after the great crisis of the 1920s. It was then that various fragments of understanding emerged about what the market economy is, what its "clean" or proper connections with the state are and what economic policy solutions are within the accepted paradigm of the economy.

The environment of economists and economic politicians, albeit with great difficulty and reluctance, gradually allows a shift in paradigm within which it operates. This is the result not only of defending careers, but also, and perhaps 
above all, the familiarity and universality of the methodology, and therefore the language in which the group communicates.

In a nutshell, the basis (starting point) of the current paradigm of thinking about the market economy is the system of individuals, free in their choices, guided by the principle of maximizing benefits (homo oeconomicus). The free market can lead to suboptimal solutions, which however is the result of market failure and not structural (unrepairable) market characteristics. The dispute is therefore about the scale of the imperfection of the market's allocation. The existing spectrum of views begins with the position that the invisible hand of the market needs the state as a "night watch", guarding the rules of fair play between market participants, and ends with attributing the state with the roles of both the guardian of the rules of the game and the creator and administrator of economic infrastructure and the so-called strategic enterprises. ${ }^{1}$

In our understanding, NSE is a departure from understanding the economy as "market that requires more or less support from the state" for the paradigm of business entities and the state as equal partners in making economic decisions. ${ }^{2}$ This is, therefore, a thesis much stronger than, for example, the view resulting from Keynesianism about the complementary fiscal and monetary role of the state in restoring the balance of full employment.

That does not, however, mean that in NSE the partnership between the market and the state is a smooth and easy task. The problems are certainly there, but these are problems of implementation, not of principles. NSE promotes the point of view that with the challenges faced by the so-called catching up countries, the limitation to just the "market or state" discussion, rather than leading to any good solutions, is pure waste of intellectual potential on false disputes and of material resources on creating and implementing unrealistic solutions.

It should be emphasized that this perspective is qualitatively different from the proposition of the dominant role of the state (e.g. Mazzucato, 2013), which is nevertheless a position in the dispute on the market or the state.

1 Extremes: (a) the total elimination of the market, after years of futile attempts by communist countries, found its well-deserved place in the dustbin of history, and (b) the market without a state found its shelter on the Internet.

2 NES does not devote significant attention to households as subjects of economic decisions (as is the case in mainstream economics derived from the classical paradigm). In our opinion, this does not result from neglecting households decisions regarding behavior on the labor market and the level and structure of consumption, but it has pragmatic reasons - the ability to shape households behavior requires a lot of time (almost a generation) and the results are still uncertain. In addition, NES is a proposal for catching-up countries, where "hunger for work and basic consumer goods" is dominant in the households decisions. 
The paradigm of the NSE economy, assuming a partnership of entrepreneurs and the state, first had to assume that both sides are equal to a certain extent. Paradoxically, this means not so much the strengthening of the state as that the state is willing to self-restrain its instruments. This is a concept referring to the history of Japan's development, and later to South Korea, and is currently being implemented in China.

Forms of partnership could be found in the activities of the government development coalition and chaebols in South Korea or the government and private corporations in the development of Japan in 1946-1970. In both cases, this partnership was operating in the context of a culture that is the heir of Confucianism, where the liberal, western concept of partnership as co-operative actors is simply unimaginable, especially in the traditional societies of these countries. However, one cannot fall into the trap of applying Western thinking about the domination of the state based on instruments of administrative coercion. In both Japan and Korea, it was communication between the state government and free private business entities. For example, maintaining a separate opinion or even aversion to the actions recommended by the allpowerful Ministry of International Trade and Industry (MITI) in Japan did not pose a threat of losing one's position, let alone losing the ownership of a private enterprise. It was similar in South Korea. This prevented, among others, the accumulation of errors in economic policy and selected directions of enterprise development.

A good illustration of this dependence is the relationship between the government and business entities in Japan in the 1950s. Well, at the beginning MITI was against the development of the car industry and electronics. Trucks, construction machines, elementary household appliances were accepted while private passenger cars or sophisticated electronics were not. However, the business stubbornly pursued its goal and after many years this rebellious concept was accepted by MITI, although at the beginning the stream of government assistance avoided these "invalid" businesses. As we know, the effect of this direction of development was the achievement by Japan and then Korea of dominant position on global markets.

The partnership between the state and the corporation is difficult to enforce because of the difference in weight of the two actors: the state may ultimately appeal to its monopoly of "the use of violence". Nevertheless, when the state sees a partner in a private corporation, respect for private property sets the boundary of forced development concepts. In this case, if MITI had more control, we would probably have neither Sony nor Japanese cars or at least their creation would have been seriously delayed. Partnership means both cooperation 
and dispute, and ultimately the possibility of breaking the relationship. This creates a healthy principle of the necessity of analyzing the partner's perspective and justifying one's position and thus enforces a compromise. These processes enable mutual adaptation and creation of new solutions that are closer to the options appreciated by the partners.

In this context, China's experience is extremely interesting for the global economy. Due to the historical legacy of an extremely nationalized economy, we are now dealing with deliberate "farming" by the state of private corporations that may become partners in the modernization program.

In conclusion, next to the state as the founder of economic policy and the controller of its implementation through ownership and similarly drastic forms as well as the state as a night guard, there is a place for the state as a private business partner. This concept, however, requires meeting two elementary conditions: on the part of the state - accepting the fact of partnership with autonomous entities able to calculate their business interests, and thus respecting these calculations, while on the part of business - accepting responsibility for the economic development, i.e. a system that goes beyond the narrow interests of a single business. This is what happened in Japan and in South Korea. In both cases, we were dealing with the formation of a business and state development coalition. In both cases, they managed to convince the rest of their societies to accept this coalition and a high level of savings, which allowed for a high investment rate.

\section{Formulating and Implementing the Economic Policy}

The goal of the NSE is that of "assisted convergence" - actions aimed at catching up with highly developed, affluent Western countries by countries aspiring to join this exclusive club.

Historically, neither the theory nor the practice of catching up is a new phenomenon, as exemplified. among others, by Rosenstein-Rodan (1943).

One historical example of a successful state-run modernization is Prussia of the early nineteenth century, which can be considered as the pioneer's formula for a centrally managed comprehensive reform, as says one of its creators, based on the "three-dimensional primacy: army, knowledge, and constitution" (Gneisenau, after: Nipperdey, 1998).

However, as revealed by the economic history successful convergence through modernization unfortunately happens rather seldom. In the modern world, 
convergence is more difficult than it used to be in the historical past. Nowadays, more than accelerating the growth by using inactive labor resources ${ }^{3}$, it means modernization of the economy through the allocation of active resources to activities with higher added value. In the first place, it is a challenge of "passive modernization" consisting in adapting solutions taken from the West. In the second one - it is a challenge of "active modernization" based on the creation and implementation of original proprietary and innovative solutions.

The reasons for the successes but also failures of modernization programs can be found both on the side of the structure of the modernization process and the practice of managing the process. ${ }^{4}$

\subsection{Structural Determinants of the Modernization Process}

On the side of the structure of the modernization process, the basic problem is that of an inevitable tension between the "political cycle" and the "modernization cycle". While the political cycles in democracies operate within perspective of a few years, "from elections to elections", modernization cycles are carried out in perspective of a dozen or so years determined by a significant increase in the share of the economy based on innovative products. Systemic modernization, i.e. based on mass innovations (rather than innovations introduced ad hoc, no matter how successful and spectacular) requires long-term measures sufficient to carry out and "root" institutional and regulatory changes that determine the effective transfer of knowledge to the economy, as well as the internalization of relevant participant behavior. Hence the temptation among the catching up countries to sacrifice democracy for modernization. The case of China also introduces a historical precedent in this respect. Only a few decades ago, the prevailing view was that Western political democracy is a prerequisite for modernization, but China's current modernization successes have undermined this argument. Of course, in the case of Poland, even for reasons of international obligations, such a dilemma is not present, although an acceptable model of democracy, due to individual solutions of the implemented practice, is quite capacious.

In this context, declarations of politicians, but also of entrepreneurs and managers, that innovations - especially based on native knowledge - are worth

3 Although it is also important especially in populous China and India, and in Africa in perspective of decades.

4 It should also be remembered that specific historical cases of success or failure also depend on many uncontrolled factors, such as the leader's personality, breakthrough political or technological events, external threats. Such phenomena, albeit undeniably important, are not considered here. 
unconditional support, are suspicious. Innovation means the disruption of the status quo on many levels. Innovation causes greater or lesser distortion of the economic and social order for many social groups, at least in the short and medium-term.

From the point of view of the state, particularly distortive impact of innovation occurs on a politically sensitive labor market. Therefore, the phenomenon of "killing innovation" by the state policy of protection of jobs in the old sectors of the economy is a reaction justified by the political cycle. First, trade unions in the old sectors are well embedded in political structures. Often, the occupations of declining sectors are perceived high in the social gradation of occupations (in Poland, such is the profession of a miner). The new and innovative sectors are deprived of such advantages - by definition they offer few jobs and, worse still, they often pose a threat to jobs in the old sectors of the economy.

The success (or not) of the social process of modernization through innovation is entangled in circular dependence of a "vicious circle" character: innovations are the engine of development, but in order for innovation to become a driving force for growth, it is necessary to achieve a sufficiently advanced level of economic development. As a consequence, the modernization challenge at the structural level is a shift from a low-potential innovation economy (Fig. 1) to the economy of high innovative potential (Fig. 2).

Figure 1.

A low innovation potential economy cycle

Simple low-paid job combined with high unemployment and low level of professional activity

Fixation of an extensive economic model until the surplus of simple and cheap labor is exhausted
Low internal demand and high job insecurity,

$\rightarrow$ low demand for products and services with a high knowledge content

Lack of motivation for innovation:

- low expenditure on $R \& D$, small capital investments (machines and personnel)

Figure 2.

The high innovation potential economy cycle

Fiscal preferences for employee training and innovative investments Pro-innovative public procurement

Moving towards an
intensive development
model with the growing
use of knowledge and
specialized work

The increase in the number of well-paid jobs gives rise to the

$\rightarrow$ demand for innovative products

Motivation for innovation: increased expenses on $R \& D$, capital investments in the company, and training of employees

Source: own study.

The transition from the cycle of low innovation potential to the cycle of high innovation potential requires time and changes, both economic and socio-political. For the continuation of these efforts to be viable in an 
uninterrupted political cycle, a consensus of political and economic elites is essential. An example of the development of South Korea shows how important such an agreement is.

The agreement of the political and economic elite was initially enforced in that country by the dictatorship of General Park, but later it became quite broadly accepted which continues to this day. In Korea, the transitional period covered six 5-year development plans. Until mid-1970s it was driven by cheap work and later, by the mid-1990s., by investments. The period of building the potential was crowned in 1996 by the membership in the OECD, and then by an intensive focus on innovation (U.S. Bureau of Labor Statistics, 2018).

Often, the level of research and development (R\&D) expenditure is assumed as condition for the transition from the low innovation potential cycle to the cycle of high innovation potential. These expenditures are obviously a prerequisite for a successful transition. However, from the point of view of modernization policy, the structure of expenditures (share of state and private participants in the research sector) and absorption of innovation by industry are of fundamental importance. The strategy of enforcing innovativeness by significantly increasing the state's expenditure on $\mathrm{R} \& \mathrm{D}$, although it brings certain results, is still largely wasted.

Looking from perspective of the experience of countries that have emerged from the group of aspirants and gained lasting presence in the group of leaders in the innovative economy, it seems that the transition from a low-potential economy to a high-potential innovation economy requires proper ordering of several important issues:

- minimizing the tensions between the political cycle and the time necessary to obtain developmental effects through the agreement of political and economic elites and agreeing on a long-term strategy;

- major investments in R\&D, probably at $2.5 \%$ of GDP and state-supported development of research potential in corporations; it is the focus upon the application that allows for accelerated effects of scientific research;

- development of an education system focused on creativity, science, technology, and cooperation between people;

- mobilization of society, public opinion, towards the development of innovation in public life and economy; this requires a serious propaganda effort, institutions, and financial outlays. ${ }^{5}$

5 This extremely important problem goes beyond the scope of this chapter. It is worth, however, to signal the key meaning of the so-called Sputnik moment - mobilization of the United States in the face of the launch of the Soviet Sputnik into the orbit. 


\subsection{Practice of Managing the Innovation Process}

A high percentage of unsuccessful modernization attempts, in our opinion, results from excessive focus on "what to do?" question, instead of giving the right answers to the "how to do?" question.

The former question not only seems to give priority to one's intentions versus one's capacities, but also inevitably leads to multiplication of tasks by interest groups, bureaucracies, and politicians. In essence, this practice is not really different from the practice of "attaching to the plan" known from the planned economy. Such an operation is greatly facilitated by the fact that numerous tasks can be justified as being socially and economically important (which they actually are, in most cases). As a result, the modernization program enjoys wide support, but has little chance of being implemented, due to inadequate material and human resources.

The question "how to do" requires a critical in-depth assessment of the available opportunities for a specific country at a given time. The difficulty of answering it lies in the fact that the range of possibilities is narrower than the scope determined by the "what to do" diagnosis so it requires reducing the number of priorities, thus violating the expectations of some interest groups.

The first step towards "what to do" is a realistic assessment of the country's place on the global map of competitiveness in relation to other countries building their advantage on innovation rather than on low costs. The current position on the global map of competitiveness and the chances of promotion need to be assessed realistically. Speaking colloquially, in which league the country is currently playing, and in which it could play in a few seasons, climbing up or falling down in the rankings, has to be assessed.

The value of even the best-conceived and socially accepted modernization program is determined by how it is implemented, and this in turn requires a proper continuum of human resources - from the broadly understood apparatus of the state, through local governments, to the organization of civil society.

The efficiency of the apparatus is decisively determined by its stability and de-politicization of officials elected on the basis of merit and integrity criteria. The importance of the official apparatus of the state in economic management is particularly important, but also rather complex in the case of the implementation of innovation policy. In the case of staff implementing innovative policies, the assessment of the effectiveness of the clerical staff is more difficult than in other areas of the state's activities, due to the "poor algorithmicity" of such an assessment and a significant time gap between the actions and their effects. There is a fundamental contradiction between the 
characteristics of good administration - dealing with standard rules and risk avoidance - and innovations which, by definition, have to boldly challenge the existing order and are burdened with significant and poorly defined risk. Hence the temptation to evaluate based on the implementation of outlays, e.g. spending state money on $\mathrm{R} \& \mathrm{D}$, can lead to a waste of resources and, worse still, the creation of "Potemkin villages" giving false sense of success.

The creation of an administrative staff meeting these conditions is only the first step. In an efficient administration system, the behavior of officials is largely shaped not by their personal qualities, but by the institutional environment - a system of rules and motivations that trigger or prohibit certain actions. Rules and regulations, formal and informal, together define the structure of the incentives of officials in a particular organization or in the public sector as a whole. The area of innovation policy requires officials to go beyond the standard range of expected personality traits - here a component of businesslike attitude is required, e.g. the ability to take risks and accept the reduction in time of the role of administration in a given area.

Administrative efficiency studies show that regardless of the state, at the level of individual motivations, to perform their duties well (in the understanding of system expectations), officials must see the connection between their effort and the future evaluation of their work. The durability and consistency of these relationships are shaped by the institutional environment in which they work (Manning, Mukherjee, and Gokcekus, 2000). However, the relationship between the behavior of officials and the institutional environment is not deterministic. In the same environment some clerks work inefficiently (although this is generally a learned inefficiency, not the result of their inherent ineptitude), some use their position to obtain side incomes, including corruption, others work efficiently, with public interest as a priority. Therefore, we can talk about the prevalence of certain behaviors in a given environment rather than an allencompassing rule.

Knowledge of the conditions for the efficient functioning of the administration does not automatically translate into the ability to reform the administration itself. The World Bank estimates that less than half of the projects supporting administrative reforms have been successful. Among the reasons for such a low effectiveness of interventions aimed at introducing more efficient and more suited to the needs of modern public management systems, the World Bank points to a too narrow, technocratic point of view on what is needed in public sector reforms and reliance on "best practices" transferred from developed countries, and often impossible to implement in developing countries. A condition for improving the efficiency of public administration reforms should be "working 
with local partners to better understand and take into account a wide range of motivations and pressures - both within and beyond the authorities - that affect the functioning of public administration" (Manning, Mukherjee, and Gokcekus, 2000, p. 1).

The problem of key importance is the functional relationship between the world of politics (government) and the world of administration (management). The political attractiveness of clientelism and the threat of corruption in the areas of public procurement, state subsidies, division of seats in state and local government organizations causes that the creation of a "Chinese wall" between the administration and the world of politics is of special importance. This applies to state administration, but perhaps it does even more to local government administration, where the boundary between governance and management is fluid (World Bank, 2008).

The traditional method of separating administration and politics is to create civil service. This concept relies upon two pillars: substantive competence and occupational stabilization. Such elected civil servants are loyal to the interest of the state over the current interests of the ruling party.

Historically, the choice of civil service in the transformation countries, including Poland, required addressing the problem of "original sin" - stabilization of the first generation of civil servants - that is, people coming from a system that proved to be out of order. At the beginning of the transformation, there was a risk of stabilization of officials who not only were shaped under the failing system, but also quickly losing their substantive qualifications (we ignore the matter of loyalty to the new political order). ${ }^{6}$ In addition, the acceleration of changes in the economy and society leads to an additional problem of the functioning of the civil service - a rapid depreciation of the knowledge of officials. The "mandarin administration" model was adequate for management in a stable environment. In times of rapid change, misunderstanding of new technologies and social behaviors and trends may even lead to obstructive, anti-innovative activities.

6 Historically, this problem has been solved in various ways. For example, in Great Britain there was a landed gentry class, which, thanks to the principle of the indivisibility of landed estates, "shoved out" people well-prepared to the civil and colonial services. In continental Europe, civil service was the instrument of exercising the power of the "enlightened" absolute monarch. These systems have also been appropriately transferred to former colonies. A specific model was adopted by classical China, where the substantive factor of the selection of officials regardless of the class was dominant (famous exams of the knowledge of thousands of writing characters). However, in no historical case, the civil service class was created in a democratic environment of power. For this reason, the United States bases the administration on the civil service on a much lesser scale than other Western countries, and much more on political nominations. 
The undoubted weakness of the Polish administration is the lack of civil service, that is, the official class chosen according to substantive criteria and not subject to exchange with the change of the ruling party. The successive governing parties sought to exchange the civil service for loyalty to politicians, manipulating the statutory grounds of the civil service, e.g. by introducing the principle of "fulfilling duties" or by resigning from the principle of competition recruitment. The need to reward the party allies and common nepotism were not without significance. "Every government - contrary to the rules of the civil service - prepares and pushes its bill for itself, but when it starts to implement it, the government already has to give its place to the next one. You can say that each of them makes the bed for the next one to lie in... Citizens are victims of constant atmosphere of danger and uncertainty" (Górzyńska, 2009, p. 198). Unfortunately, this opinion is still valid.

In the case of Poland, the difficulty of building an administration capable of managing the innovation process must be confronted with the fact of unprecedented growth, in the last two decades, of the number of university graduates of the majors required in efficient administration: economics, law, management and administration. During the initial period of transformation, the option of working in administration was losing with the opening possibilities in private business, much more attractive both financially and socially. The improvement of the general standard of work in administration and the increase of competition on the private market caused that "work in the office" becomes a considered alternative for young university graduates. This confirms the thesis about the politicization of employment in the administration, but also in the commercial companies under the direct control of the government and local governments. Having access to educated graduates, the Polish political class does not have to build from them an efficient, politically universal official apparatus.

The progressive shifting of the center of gravity of innovative activities from the space of individual activities at the connection between science and enterprise for activities into the social space requires a new type of partner for state administration in conducting pro-innovation policy - an as wide and diversified as possible range of civil society organizations: from associations of producers, through independent research centers (think tanks), to charities. The experience of highly developed countries confirms the growing development role played by non-governmental organizations, in particular as regards:

- intermediation between the administration and citizens - on the one hand, as to the transmission of aspirations, questions, and proposed civic alternatives, and on the other hand - as to the transmission of government intentions and actions in a manner comprehensible to citizens; the function of "translating" 
the intentions of the economic policy administrator will become increasingly important as more and more areas of economic policy cannot be assessed directly by citizens and require a professional but independent evaluation;

- social control of administrative activities (accountability) as to their transparency and use of funds;

- providing services such as training, eligibility of policy beneficiaries, etc.

The tissue of social organizations in Poland is still underdeveloped. Such activity is still associated by Poles more closely with Stefan Żeromski's protagonists than with a systematic and pragmatic contribution to their environment, which does not require dramatic life sacrifices.

A richly structured civil society with a dense network of non-profit organizations that support the diversity of society is a property of Protestant culture (we are aware of serious simplification in this assessment). The undeniable cause of poor development of systematic activities of social organizations in the transformation years was the emergence of opportunities to improve the well-being of their family and loved ones through increased professional effort, directly competing for the same time budget with activities for "strangers". There was also the possibility of occasional charity activities (such as WOŚP [The Great Orchestra of Christmas Charity]), a positive phenomenon in itself, but giving people justification for poor participation in social organizations. Undoubtedly, bad experiences of pseudo-social organization of Communism has also played a role here. Yet another dimension of this phenomenon is the durability of cultural features.

Social activity supporting modernization activities has been on a similar level for several years without any upward trend. About $1 / 3$ of society is active. In volunteering, $1 / 5$ is involved in formal organizations, and about $1 / 4$ of the population in actions for people outside the circle of family and friends or for the benefit of the neighborhood ${ }^{7}$ (Adamiak, 2014).

\section{Participation in the Global Economy}

In the foreseeable future, we will be exposed to ever more brutal competition in the globalized economy, both for resources and for outlets. This is primarily

7 The percentage of respondents declaring their involvement in volunteering for a charity organization is probably high, as some of the respondents were able to consider material support for these organizations as volunteering. 
influenced by the geopolitical factor - the extension of the competition area to supply resources and markets from countries that are not yet significant entities of the global economy. The geopolitical factor is revolutionarily strengthened by new technologies that reduce the transaction costs of moving people, goods, and information, and thus allowing the creation of global flexible production chains - new rules for capital allocation.

\subsection{Poland in the Face of the Challenges of Global Competition}

Under the new conditions, competition methods will change, which will give Poland the chance to improve its position in the global economy. So far, the development based on producing more of the same, in the best case with a change in technology leading to a reduction of costs, was the dominant development strategy. In the Polish economy there were serious technological and organizational changes, the carrier of which were new production methods implemented to companies by new, generally foreign business owners (privatized and greenfield). Technological and organizational innovation did not result from original Polish inventions or the pressure of Polish entrepreneurs to implement them. It took place as a result of the absorption of technologies and organizational solutions invented outside Poland; as a rule they were innovative imitations in relation to foreign parent companies.

In general, foreign business owners retained well-prepared employees, the product market as well as the product brand, and then modernized the production process by introducing new machines, perfecting product design and marketing. It was a passive process of injecting innovation into the economy. An example may be the dairy products market, where the old names and flavors of products often hide the new technology of their production, obtaining raw materials and distribution - thus reducing costs, including those of employment.

The autonomous demand for innovation was related to the somewhat organic response to the inefficiency of the planned economy system. During the transformation, Poland experienced a real explosion of small businesses, a phenomenon widely admired in the world as a proof of the natural need for economic self-realization in a market economy. Transformation has created enough space for a group of enterprising people going into millions. New entrepreneurs, when establishing small companies, were inevitably buying new machines and technologies, more efficient compared to previously existing ones, even if they were second-hand after several years of use in the west. In Polish conditions, it was still a huge innovative leap (just like a five-years old Mercedes is still much better than a brand-new Lada). 
The modernization based on "filling in the gaps" inherited from the past obviously has its limitations - its causative power lapses with the removal of the old system's malfunction.

The current modernization only gave an indirect strengthening of the competitiveness of the Polish economy - replacement of imported products with local ones. ${ }^{8}$ However, it failed to create the potential for competing on global markets. The development by entering higher levels in the product value creation chain and changing the structure of the economy by increasing the share of sectors with higher productivity and uniqueness is of course the best way to modernize, giving the greatest opportunities for productivity growth and competitiveness in the dimension of not only individual enterprises, but also the entire economy and society. Unfortunately, and despite the progress of recent years, this is still not very much the case of Poland.

\subsection{NSE Against the Challenges of Global Competition}

The great temptation of state modernizers is economic protectionism. This applies both to the protection of old industries and the infant industries. While such a model of modernization could make sense in the $20^{\text {th }}$ century, it no longer does (and more importantly, it has become short of instruments now) in the era of free trade and the emergence of innovative product substitutes. ${ }^{9}$

NSE protagonists are aware of the failure of the state's modernization activism based on protectionism. In particular, lessons were learned from the failure of the import substitution policies, popular in Latin America in the 1960s and $70 \mathrm{~s}$, which consisted in supporting domestic producers offering products replacing imported products. This policy, justified by the desire for accelerated modernization, has had effects opposite to expected. Despite short-term benefits, such as increased employment and the creation of a limited number of better-

8 An example of this is the repression of foreign food products, en masse entering the Polish market in the early years of transformation, by Polish products, thanks to their increased attractiveness.

9 The drama of America first protectionism or the French defense against "social dumping", which unfolds before our eyes, can have far-reaching consequences for the program of innovative modernization in countries such as Poland. Symptomatic was the reaction of E. Macron on the plans of Whirlpool companies to transfer production from France to Poland. "Macron talked to the regional daily of Northern France after Wednesday's meeting in Amiens with workers on a strike of Whirlpool factory, which will be closed due to the relocation of production to Łódź [...] Within three months after choosing me (for president) a decision will be made on Poland", said Macron. Acquired from: https:/www.bankier.pl/ wiadomosc/Francja-Macron-opowiea-sie-za-sankciach-wobec-Polski-3685431.html. 
paid jobs, the lack of competition led to low innovation and low productivity, and consequently to high prices with poor quality of local products compared to imported products. Moreover, the discretion of protectionism led to increased corruption and deepening income inequalities (Lustig et al., 2013).

Therefore, NSE postulates the implementation of a modernization program within the framework of an economy open to competition challenges on a global scale, even using its mechanisms and economies of scale. This is a proposition based not on the zero-one game, but on the activities with benefits for all participating parties of the agreement. This, in turn, requires coordination and cooperation at the state level. An example of such coordination is to be a crossborder program of the so-called New Silk Road.

The integrating argument underlying the benefits of such coordination between states is supposed to be a similar relationship of catching up countries in relations with highly developed countries - their peripherality.

In the relationship between the center and the periphery, the type of investment or, more broadly, the international division of labor is of a structural nature. Foreign direct investments in catching up countries from Western countries are generally concentrated in traditional sectors with a low degree of investment risk, and thus of low saturation with innovations. Foreign investments reach sectors with significant energy consumption and for environmental reasons not tolerated in developed countries, such as cement plants or steelworks and assembly plants that use cheap labor (we should not confuse the assembly of high technology products with innovations). Attempts to motivate foreign investors to invest in innovative projects, e.g. by tightening environmental regulations, may lead to consequences opposite to those intended - limiting the inflow of investments to traditional sectors and escape to countries ready to accept the conditions set by investors.

Limiting the transfer of innovation from the top shelf to the peripheral countries has its rational business basis. In the first place, it may be dictated by weaker workforce preparation and lower externalities than in the countries of origin. Although the workforce in Poland may have (and often has) a higher formal education than the workforce in developed countries, the practical knowledge (tacit knowledge) is decisive for the investor, and it is gained practically by imitating the masters of the profession and by participating in the employee group. It is difficult to transfer between countries or communities and is acquired over years. The requirements of practical knowledge are the more common and easier to obtain, the lower is the activity technologically located in the production chain. 
The strict environmental and labor standards in developed countries are an important reason for the transfer of business elements that do not meet them, to countries willing to accept less stringent standards. The motive of the location is therefore the possibility of externalization of costs related to compliance with standards. This applies to a significant extent to „dirty” elements of the production chain, usually with the lowest saturation with high technology and the least innovative ones.

The fact cannot be ignored that the latest, most innovative products and technologies determining the competitive advantage are under the strictest protection of the enterprises that produce them. Therefore, they look with great suspicion on proposals for improvements proposed by subcontractors from peripheral countries - the risk of losing the monopoly in the field of product improvement is often reckoned greater than potential benefits resulting from the possibility of cost reduction.

In the reduction of the center-periphery innovation flow, non-business factors also play an important role. Foreign corporations, in the event of global demand constraints, are under great political pressure - to which they often succumb - to relocate production ranked high in the value creation chain from the peripheral country to the investor's country of origin. The issue of the so-called nationality of capital, or rather the submission of foreign owners to the political pressures of their countries of origin, returned with increased strength in the aftermath of the 2008 crisis. The effect of liquidation, in the peripheral country, of production with high saturation with modern innovative solutions is the unfavorable change in the structure of the economy into less innovative and the reduction of the pool of well-paid jobs. In the long-term, this means liquidation of places where employees can acquire practical knowledge, which adversely affects the social capacity to build innovative potential in the entire economy.

\section{Conclusions}

Modernization of the economy means moving to a model that allows obtaining significant revenues from participation in the global economy at a higher level of value chain within the existing sectors of the economy and changing the structure of the economy consisting in increasing the share of sectors with higher productivity and better global competitiveness.

This task is not easy. The results depend to a large extent on the ability to launch the social ability to innovate as a systematic activity aimed at better 
use of available resources and better meeting the needs, this depends on the ability to cooperate - establishing developmental coalitions between the state and enterprises. In this context, the question must be asked, with whom from the sphere of business in Poland in the coming decades can the state create a development coalition?

The Polish economy is dominated by micro-enterprises employing up to 9 people (96\% of the total). The Polish economy has only about 3,500 (0.2\% of the entire collection of non-financial sector enterprises) of large enterprises. The sector of large enterprises is dominated by state-owned companies and companies controlled by foreign capital. Among the 10 largest companies (by sales volume), $54.9 \%$ are revenues of companies controlled by the state. Among the transformation countries, a larger share of the state-controlled sector is only in Ukraine (68.9\%) (Szarzec, 2016, p. 130). The average employment in companies controlled by the state is 243 employees, by foreign capital 230 , and by domestic capital 72 people. The sector of large companies controlled by domestic capital essentially does not increase, while the sector of statecontrolled companies grows up (Błaszczyk, 2017).

Small and medium-sized enterprises, although they constitute the core of the Polish economy in the sense of the proportion of employment and contribution to GDP, have neither enough capital nor human resources to actively participate in the research and development market. On the other hand, the sector of state-owned enterprises, in spite of including large enterprises, has only $8 \%$ of export revenues, which means the lack of strong competition on the market, which verifies the innovative potential.

Foreign companies in Poland play and in the foreseeable future will continue to play a significant role in introducing innovations to the Polish economy - both capital and non-capital. Therefore, Poland's attractiveness for foreign investments should be maintained as they are major source of inflow of new products, technologies, and methods of organization and management from the outside. Foreign companies can and should be treated as an important source of innovation for Polish cooperating companies. However, this requires skillful support from government authorities, which, as shown by technology transfer associated with the purchase of Western weapons, is not a simple task.

However, it must be realized that such a strategy means the dominance of imitative innovations that are generated and installed by Polish contractors as part of production tasks commissioned from globally-operating mother companies. Non-sovereign innovations involve two types of risk. Firstly, such innovations may be withdrawn from Poland in the case of moving production to locations more profitable from the point of view of the parent company. Secondly, 
non-sovereign innovations, generally embodied in imported machines, do not develop local innovation potential, for example, through reverse engineering (in Poland impossible for many reasons), which lay at the basis of the initial success of the Far East countries.

An increasingly popular area of economic activism of the state is supporting startups, especially in fashionable areas such as biochemistry or IT. This is an important activity, for instance for triggering the "social innovation energy", popularizing success based on talent and knowledge as the main driving force of modern economies. However, it should be remembered that for a transition from startup to implementation, you need a whole business ecosystem, which, unfortunately, is lacking in Poland. Therefore, by increasing the state's involvement in the development of startups, their significant impact on the economy should not be expected.

The direction of the modernization development coalition, in which the current government has the highest hopes, but which is also the most controversial, is the use of large ventures (companies) controlled by the State Treasury. The explicit justification is that only these "non-limit" companies have significant capital resources necessary to implement capital-intensive modernization programs (such as the central airport). The implicit justification is the ease of "convincing" the management of these companies to invest in selected programs. In the case of SP companies, it is a natural instinct to appeal to administrative and political domination, only formalistically hidden under the guise of ownership interventions. This accusation is even more relevant to enterprises controlled by local governments, where the temptation of nepotism and corruption is stronger due to weaker social control. ${ }^{10}$

The successful use of capital resources of SP companies in the process of modernization of the economy requires a combination of: (1) selection of management personnel based on purely substantive criteria; (2) compliance with good corporate governance, in particular exclusion of interventions "on the phone"; (3) a professional external evaluation system (audit) of companies.

As a result of these restrictions, in contrast to the Asian examples of success, in Poland the policy based on the NSE suggestions has no obvious candidate

10 In the Polish legislation, the construction of the SP company appeared in the privatization law of 1990 (which the authors co-created). The original intention was to give large state enterprises "in line for the privatization" a market form. From the perspective of the years, this was naive thinking, underestimating the political interests around these companies. However, the alternatives were also flawed. This was shown by the privatization in both Russia and Czechoslovakia. 
for creating a development coalition. This is the most serious limitation of this concept as a suggestion for creating catching up strategies.

In this context, a better balance of economic activity by strengthening cooperation with other catching up countries makes sense. In the first place, strategic pragmatism recommends presence on a maximum possible number of markets, especially during far-reaching changes in the global economic order. The Polish economy is to a significant (in our opinion excessive) degree dependent on the German economy ( $1 / 4$ of exports). This is particularly important with the expected export opportunities in the Asia-Pacific region markets, which are becoming the most dynamic region of the middle-class growth and related demand. In 2015, consumer spending (PPP, in USD 2011) of the US accounted for USD 4.7 trillion, which accounted for $13 \%$ of world consumer spending, and for China it amounted to USD 4.2 trillion, which accounted for $12 \%$ of world consumer spending, for Germany respectively USD 1.5 trillion and $4 \%$ of global expenditure. The forecasted figures for 2030 are: for US, USD 4.7 trillion and $7 \%$ of world consumer spending, for China USD 14.3 trillion and 22\%, Germany USD 1 trillion and 2\% (Kharas, 2017).

One should, however, be aware that Poland's modernization aspirations may interfere with the interests of the economies and companies of both the center and the periphery; both at the strategic level and in specific cases. The model of participation in the global economy has so far been implemented through relations with the investors of the center. NSE, with its redefined role of state and national interest, on the one hand leads to a redefinition of cooperation with traditional Western partners towards greater selectivity and investment conditions (e.g. tax holidays). On the other hand, it requires new skills in running economic policy under the conditions of a different culture of cooperation and asymmetry of the potential of partners. ${ }^{11}$

Polish companies are beginning to enter the global market, where they are under a great competitive pressure, rewarding technologies and the latest products. Therefore, there are not many such companies, but there are many companies that cooperate with the largest global corporations operating on a global scale. This is the case even in the car industry. These co-operators are also under pressure: searching for new methods of management, production, employee training, improving quality. Indirectly, just like the companies for whom they work, they compete on global markets. This fosters complementary innovation. This mainly applies to the growth opportunities of medium-sized

11 Symptomatic is the " $1+16$ " formula of cooperation between China and 16 countries of Central and Eastern Europe - the population of " 16 " is less than $10 \%$ of the population of China. 
companies with Polish capital and original Polish products and technologies. A question arises about an extent to which the state can consciously "breed" large companies based on Polish capital? It seems that the use of the oligarchic patterns from Asia would encounter a barrier of social distrust having its origins in creating fortunes in times of turbulent transformation. These fortunes were too often created as a result of unclear relations between the state apparatus and businessmen (although in Poland these practices were much less frequent than in the former USSR).

Ultimately, the deciding factor for Poland's modernization success will be the pro-modernization attitude of business entities, employees, and consumers (hence the whole society). The New Structural Economics Apparatus can be helpful in strengthening the role of the state in meeting the challenges facing the Polish economy, but one should be aware that the application of NSE can face many important challenges and limitations. First of all, large companies needed to create an innovative development coalition are either owned by foreign corporations or remain state-owned. Secondly, not many Polish small and medium-sized enterprises grow large enough to undertake the effort of global competition. Thirdly, the society, including entrepreneurs, is suspicious of state institutions, and the state is very distrustful about public-private projects. And finally, fourthly, Poles after years of scarcity want to consume and not save, thus they are not prone to promises to improve the future standard of living in exchange for disciplined serving the interests of the state and corporations.

Therefore, further modernization of the Polish economy will be the resultant of social, political, and international constraints as well as developmental motivations of society. In the system of international circulation of goods, services, money and people, a series of adjustments awaits us, the nature of which is difficult to predict today. The main internal challenge is the secular demographic change: the aging of society and the decline in professional activity. Paradoxically, the transition to the employee's market may prove to be a strong motivator for entrepreneurs for labor-saving technological innovations and management.

Individual consumer motivations in Poland are very high, while motivations for creating forms of co-development with the state of the development policy seem insufficient. The result is the domination of the state in the articulation of goals and directions of development, with weak participation of economic and social entities. For a country wishing to pursue a more active economic role in accordance with the recommendations of the New Structural Economics, this may mean a trap of erroneous, because not externally evaluated, economic policy priorities, as well as the selection of inappropriate methods and people 
to implement them. "Pride goes before destruction, a haughty spirit before a fall." This wisdom of King Solomon should hang over the desk of every NSE policy official. ${ }^{12}$

\section{References}

Adamiak, P. (2014). Zaangażowanie spoteczne Polek i Polaków. Wolontariat, filantropia, $1 \%$ $i$ wizerunek organizacji pozarzadowych. Raport z badania 2013. Warszawa: Stowarzyszenie Klon/Jawor.

Błaszczyk B. (2017). Zmiany w systemie instytucjonalnym polskiej gospodarki. Wypieranie własności prywatnej rynku przez państwo w ramach „Dobrej Zmiany”. In: W. Gadomski (ed.), Raport: Perspektywy dla Polski. Polska gospodarka w latach 2015-2017 na tle lat wcześniejszych i prognozy na przysztość. Warszawa: FOR. Acquired from: perspektywy. for.org.pl/wp-content/uploads/2017/11/Raport_Perspektywy_internet.pdf.

Górzyńska, T. (2009). Służba cywilna w Polsce: Problemy z tradycją, problemy z przyszłością. In: J. Supernat (ed.), Między tradycja a przyszłościa $w$ nauce prawa administracyjnego. Ksiega jubileuszowa dedykowana Profesorowi Janowi Bociowi (s. 189-199). Wrocław: Wydawnictwo Uniwersytetu Wrocławskiego.

Jędrzejczak, G. and Sterniczuk, H. (2017). Nowa Ekonomia Strukturalna a polskie wyzwania rozwojowe. In: J.Y. Lin, A.Z. Nowak (eds.), Nowa Ekonomia Strukturalna wobec krajów mniej zaawansowanych. Warszawa: Wydawnictwo Naukowe Wydziału Zarządzania Uniwersytetu Warszawskiego.

Kharas, H. (2017). The Unprecedented Expansion of the Global Middle Class. Global Economy \& Development, Working Paper, 100, February. Washington, DC: The Brookings Institution.

Lustig, N., Lopez-Calva, L.F. and Ortiz-Juarez, E. (2013). Deconstructing the Decline in Inequality in Latin America. Policy Research Working Paper, No. 6552. Washington, DC: World Bank. Acquired from: https://openknowledge.worldbank.org/handle/10986/15915.

Manning, N., Mukherjee, R. and Gokcekus, O. (2000). Public Officials and Their Institutional Environment: An Analytical Model for Assessing the Impact of Institutional Change on Public Sector Performance. Policy Research Working Paper, No. 2427. Washington, DC: World Bank. Acquired from: https://openknowledge.worldbank.org/handle/10986/19797.

Mazzucato, M. (2013). The Entrepreneurial State Debunking Public vs. Private Sector Myths. London-New York-Delhi: Anthem Press.

Mracek, K. (2012). Middle-Class Spenders Will Lead Global Growth. Washington, DC: Kiplinger Washington Editors Inc. Acquired from: https://www.kiplinger.com/article/ business/T019-C021-S001-middle-class-spenders-will-lead-global-growth.html.

Nipperdey, Th. (1998). Deutsche Geschichte 1800-1866. Bürgerwelt und starker Staat. Munich: Verlag C.H. Beck.

PARP. (2017). Raport o stanie sektora małych i średnich przedsiębiorstw w Polsce 2017. Warszawa: PARP. Aquired from: parp.gov.pl/images/PARP_publications/pdf/raport $\% 20$ o\%20stanie $\% 20$ sektora $\% 20 \mathrm{msp} \% 20 \mathrm{w} \% 20$ polsce_2017.pdf.

12 Księga Przysłów, 16,18, przekład Biblia Tysiąclecia. 
Rosenstein-Rodan, P. (1943). Problems of Industrialization of Eastern and South- Eastern Europe. Economic Journal, 53(210/211), pp. 202-11.

Struktura sektora przedsiębiorstw w Polsce na tle krajów UE. (2018). Ernst and Young. Acquired from: https://www.ey.com/Publication/vwLUAssets/ey-raport-polskieprzedsiebiorstwa-2017-02-mikrofirmy/\$FILE/ey-raport-polskie-przedsiebiorstwa-201702-mikrofirmy.pdf.

Szarzec, K. (2016). Przedsiębiorstwa państwowe w krajach Europy Środkowo-Wschodniej. Studia Ekonomiczne Uniwersytet Ekonomiczny w Katowicach, 260, 125-136.

U.S. Bureau of Labor Statistics. (2018). Real GDP per capita in the Republic of Korea (South Korea) (DISCONTINUED) [KORRGDPC], August 31. FRED, Federal Reserve Bank of St. Louis. Acquired from: https://fred.stlouisfed.org/series/KORRGDPC.

World Bank. (2008). Public sector reform: what works and why? An IEG evaluation of World Bank support (English). Washington, DC: World Bank. Acquired from: http://documents. worldbank.org/curated/en/311251468150314338/Public-sector-reform-what-works-andwhy-An-IEG-evaluation-of-World-Bank-support. 


\section{The Process of Catching up with the Economic Development of OECD Countries and the Role of Foreign Direct Investment in this Process}

The article consists of two parts. In part one we describe the level of economic development of 51 countries associated with the Organization for Economic Cooperation and Development (OECD) in terms of their GDP per capita. We suggest dividing these countries into three groups: highly, moderately, and least developed. Then, using the average annual growth rate in the period 2005-2016, we distinguish countries: developing, in stagnation, and in recession. Combining these two variables, we propose to distinguish 7 subgroups of countries: from highly developed fleeing, through highly developed stable and caught up countries to the countries medium and least developed that are catching up.

In part two of the article we analyze foreign direct investment (FDI) in global terms, OECD countries, and the European Union (EU); in particular we examine capital flows between the previously specified three (high, medium and least developed) groups of OECD countries. Finally, we present regression models confirming the positive feedback between FDI and economic growth. They testify to the pro-cyclical impact of foreign direct investment.

Keywords: Highly, Moderately and Least Developed Countries; OECD Countries; Countries Fleeing, Catching up and Caught up; Foreign Direct Investment.

\section{Introduction}

The New Structural Economics (NSE) is a theoretical base of the economic policy of the state supporting economic growth, mainly dedicated to the catching-up economies ${ }^{1}$. Catching up is an attribute of any racing competition.

1 This is evidenced by the title of the article by J.Y. Lin "Nowa Ekonomia Strukturalna dla gospodarek doganiających" (New Structural Economics for catching-up economies) (cf. Lin, 2017). 


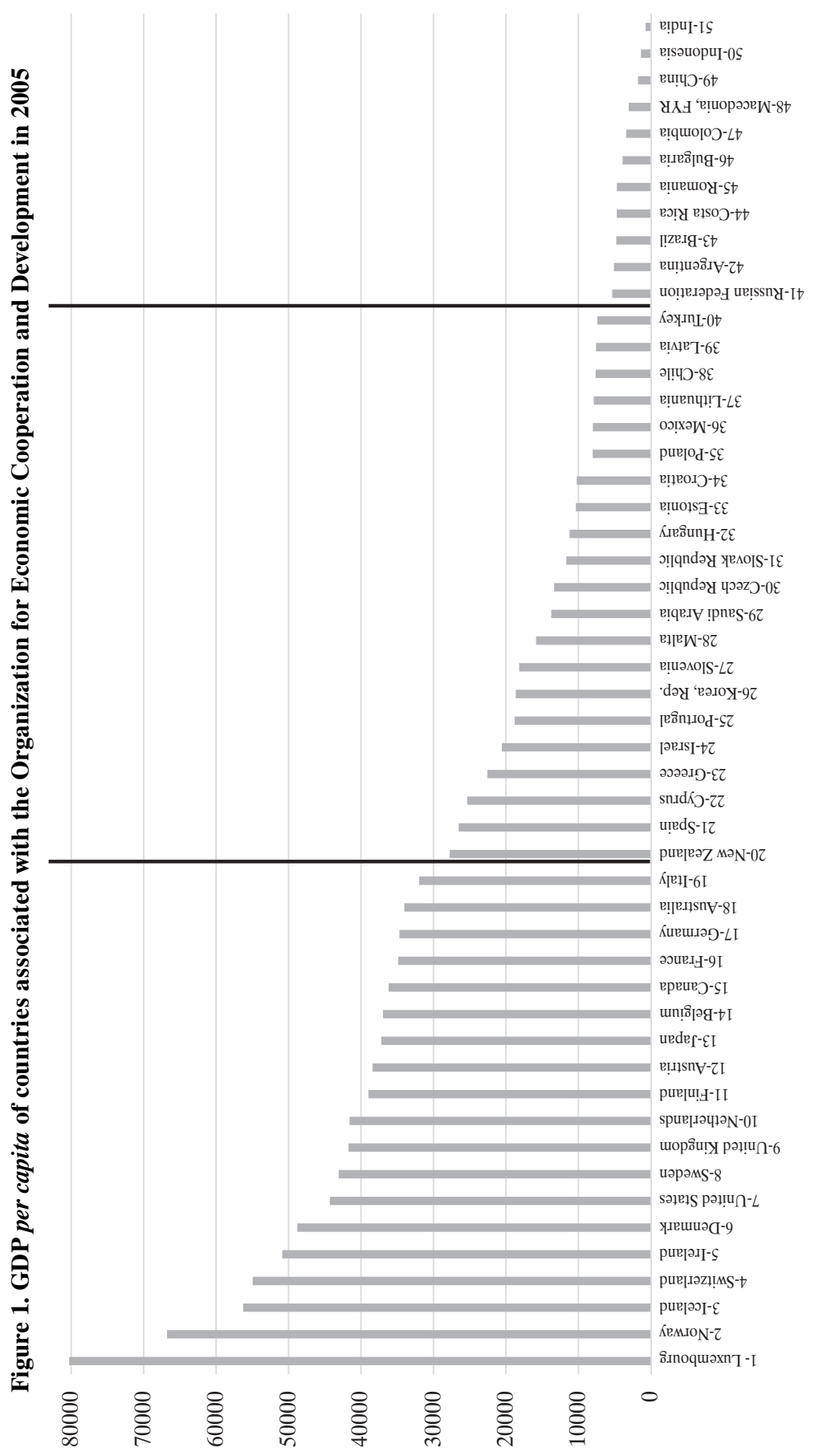


This prompted us to examine how this race of countries catching up with the leaders - the most developed ones - looks like. The analysis is limited to the database of 51 countries associated with the Organization for Economic Cooperation and Development (OECD). This is a type of sports report from the race in which these countries compete in the process of economic development occurring in the period 2005-2016.

Countries associated with the OECD have different statuses. 36 countries have the status of a member. Poland joined this Organization in 1996. Eight countries aspire to membership in the OECD (e.g. Russian Federation), other countries included in the study have signed agreements for enhanced cooperation (https://data.oecd.org). Belonging to the OECD is a certain ennoblement for the state concerned and has an unquestionable impact on its risk assessment and rating 2 . The full list of countries included in the survey is shown in Figure 1.

\section{Degree and Rate of Development of OECD Countries}

As the only measure of the level of economic development of a country we accept Gross Domestic Product per capita (GDP per capita). We are aware of its informative limitations, but there is no other similarly synthetic indicator. Figure 1 shows the level of GDP per capita in OECD countries in 2005, that is at the start of the race. It must be admitted that the spread of levels of GDP per capita is very high. The highest - 80,000 USD is in Luxembourg, the lowest is 707 USD in India. We offer the division of OECD countries taking the GDP per capita into consideration, into three groups:

- 19 highly developed countries with GDP per capita ranging between 30-80 thousand USD,

- 21 moderately developed countries: GDP per capita in the range of 5-30 thousand USD,

- 11 least developed countries - GDP per capita 0.700-5 thousand USD.

In the first group, 6 countries with the highest level of GDP per capita deserve attention: Luxembourg - 80,000 USD (position 1), Norway - 68 thousand USD (position 2), Iceland - 58 thousand USD (position 3), Switzerland - 55,000 USD (position 4), Ireland - 50,000 USD (position 5), Denmark - 49,000 USD

2 Before the Basel II adoption, a risk weight of 0.2 was used to calculate the solvency ratios of banks for claims from financial institutions operating in OECD countries, while for others the risk weight was 0.5 . 
(position 6). These countries, it seems, have something in common. They are relatively small West European countries that have a centuries-long tradition of a capitalist economy, have avoided the ravages of war, in particular losses suffered in the World War II. The United States is in $7^{\text {th }}$ place (42,000 USD), and Germany is $17^{\text {th }}(35,000$ USD). The group of the most developed countries ends with Italy (31,000 USD).

The second group of moderately developed countries begins with New Zealand (28,000 USD), with Turkey ranking last (7,000 USD). This group is made up of Southern European countries belonging to the PIGS group (Portugal, Italy, Greece, Spain) and countries referred to as emerging markets: from Central and Eastern Europe (including Poland - 8,000 USD; position 35), Asia (Turkey 7,000 USD; position 36) and South America (Mexico - 8,000 USD; position 40).

The third group i.e. the least developed countries consists of large countries from Europe and Asia: the Russian Federation - 500 USD (position 41), China - 200 USD (position 49), Indonesia - 150 USD (position 50), India - 100 USD (position 51) and South America: Argentina - USD 400 (position 42), Brazil - USD 300 (position 43).

In Figure 2 we present the average annual GDP growth rates in constant prices $(r)$ in 51 surveyed countries in 2005-2016. On the global scale, in the period 2005-2007 there was a high and improving economic situation, then a collapse and crisis in 2008-2010 followed by the overcoming of the crisis and return to better economic situation in 2011-2016. Individual countries experienced this in a significantly different way. The highest growth rates were achieved by: China $-10.4 \%$; India $-8.4 \%$; Indonesia $-6.1 \%$; Turkey $-5.0 \%$. Two countries had negative rates over this period: they were Greece at minus $1.9 \%$ and Italy with minus $0.2 \%$. Poland with the average annual growth rate of $4.1 \%$ came in $13^{\text {th }}$ place following Chile $(4.2 \%)$ and before Malta $(3.9 \%)$. Taking into account the average annual growth rate, we divided the surveyed countries into three groups:

- developing countries $(29) r=(+2+10 \%)$;

- countries in stagnation $(15) r=(+1+2 \%)$;

- countries in recession $(7) r=(-1+1 \%)$.

By far, the largest number of countries (29) have seen significant economic growth. Very important from the point of view of NSE are countries from the group of the least and moderately developed. Only 7 countries recorded the processes of stagnation and recession, mainly Japan (0.07\%) and selected European countries: Finland (0.08\%), Cyprus (1.0\%), Portugal $(0.01 \%)$, Italy $(-0.02 \%)$ and Greece $(-1.9 \%)$. 

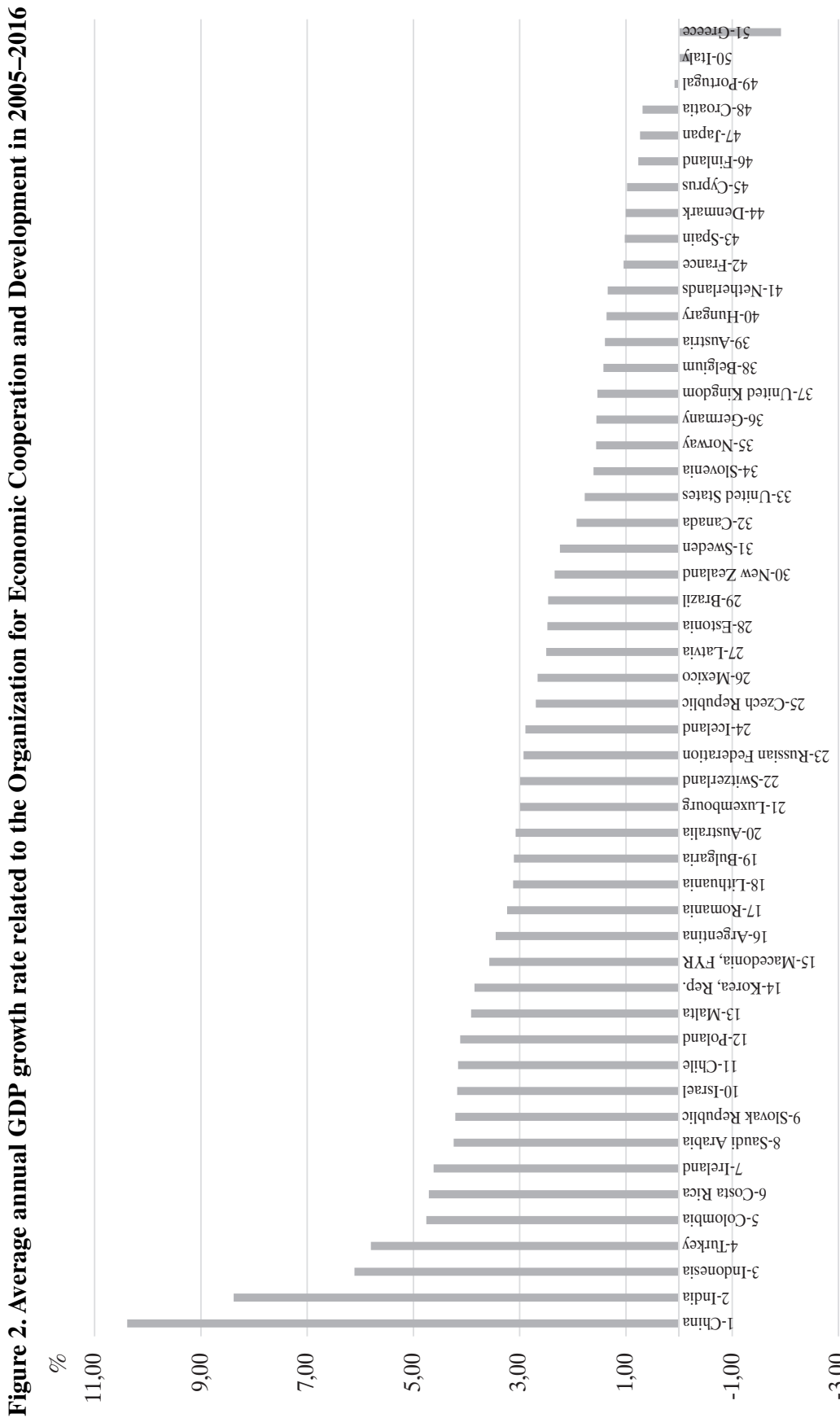
Taking into account two criteria, the level of GDP per capita at the beginning of the period (2005) and the average annual growth rate (y) in the period 2005-2016, we can separate 7 groups out of the 51 countries studied.

Table 1. Classification of OECD countries taking into consideration GDP per capita in 2005, economic growth rate (y) in 2005-2016 and long-term credit rating for liabilities expressed in foreign currency by $\mathrm{S} \& \mathrm{P}$

\begin{tabular}{|c|c|c|c|c|}
\hline No. & $\begin{array}{c}\text { Group } \\
\text { of countries }\end{array}$ & Criterion & $\begin{array}{l}\text { Number } \\
\text { of } \\
\text { countries }\end{array}$ & $\begin{array}{c}\text { List of countries along with the issuer's } \\
\text { long-term rating regarding liabilities } \\
\text { expressed in a foreign currency } \\
\text { published by S\&P }\end{array}$ \\
\hline $1 \mathrm{a}$ & $\begin{array}{l}\text { Developed } \\
\text { fleeing }\end{array}$ & $\begin{array}{l}\mathrm{GDP}>30,000 \text { USD } \\
\mathrm{r}>2 \%\end{array}$ & 5 & $\begin{array}{l}\text { Luxembourg AAA, Iceland AA-, } \\
\text { Ireland A+, Sweden AAA, } \\
\text { Australia AAA }\end{array}$ \\
\hline $1 b$ & $\begin{array}{l}\text { Developed } \\
\text { stable }\end{array}$ & $\begin{array}{l}\mathrm{GDP}>30,000 \text { USD } \\
\mathrm{r}=(+1+2 \%)\end{array}$ & 11 & $\begin{array}{l}\text { Norway AAA, Switzerland AAA, } \\
\text { Denmark AAA, United States AA+, } \\
\text { United Kingdom AA, } \\
\text { Netherlands AAA, Austria AA+, } \\
\text { Belgium AA, Canada AAA, } \\
\text { France AA, Germany AAA }\end{array}$ \\
\hline $1 \mathrm{c}$ & $\begin{array}{l}\text { Developed } \\
\text { caught up }\end{array}$ & $\begin{array}{l}\text { GDP }>30,000 \text { USD } \\
\mathrm{r}=(-1+1 \%),\end{array}$ & 3 & Finland AA+, Japan A+, Italy BBB- \\
\hline $2 \mathrm{a}$ & $\begin{array}{l}\text { Moderately } \\
\text { developed } \\
\text { catching up }\end{array}$ & $\begin{array}{l}\mathrm{GDP}=30,000 \\
\mathrm{USD}-7,000 \mathrm{USD} \\
\mathrm{r}>2 \%\end{array}$ & 13 & $\begin{array}{l}\text { New Zealand AA, Israel A+, } \\
\text { South Korea AA, Malta A-, } \\
\text { Saudi Arabia A-, Czech Republic AA-, } \\
\text { Slovak Republic A+, Poland BBB+, } \\
\text { Mexico BBB+, Lithuania BBB+, } \\
\text { Chile AA, Latvia A-, Turkey BB }\end{array}$ \\
\hline $2 b$ & $\begin{array}{l}\text { Moderately } \\
\text { developed } \\
\text { stable }\end{array}$ & $\begin{array}{l}\text { GDP }=30,000 \\
\text { USD }-7,000 \text { USD } \\
\mathrm{r}=(+1+2 \%)\end{array}$ & 4 & $\begin{array}{l}\text { Spain } \mathrm{BBB}+, \text { Slovenia A, } \\
\text { Hungary BBB-, Estonia AA- }\end{array}$ \\
\hline $2 \mathrm{c}$ & $\begin{array}{l}\text { Moderately } \\
\text { developed } \\
\text { caught up }\end{array}$ & $\begin{array}{l}\text { GDP }=30,000 \\
\text { USD }-7,000 \text { USD } \\
\mathrm{r}=(-1+1 \%)\end{array}$ & 4 & $\begin{array}{l}\text { Cyprus BB, Greece B-, Portugal BB+, } \\
\text { Croatia BB+ }\end{array}$ \\
\hline $3 a$ & $\begin{array}{l}\text { Least } \\
\text { developed } \\
\text { catching up }\end{array}$ & $\begin{array}{l}\text { GDP }<7,000 \text { USD } \\
\mathrm{r}>2 \%\end{array}$ & 11 & $\begin{array}{l}\text { Russian Federation BB+, } \\
\text { Argentina B-, Brazil BB, } \\
\text { Costa Rica BB-, Romania BBB-, } \\
\text { Bulgaria BB+, Colombia BBB, } \\
\text { Macedonia BB-, China AA-, } \\
\text { Indonesia BB+, India BBB- }\end{array}$ \\
\hline
\end{tabular}

Source: own calculations based on OECD data and Thomson Reuters Database.

By far the largest number of (11) highly developed countries was in the stable economies group with moderate economic growth $(1-2 \%)$. These countries include the United States and the main countries of the European 
Union (EU). All the least developed countries and the majority of moderately developed countries were in the group of catching-up countries (24), which seems to create good prospects for development, popularization, and practical use of NSE's ideas and concepts.

The diversified rate of economic growth resulted in changes in the classification of OECD countries in terms of GDP per capita. This classification for 2016 is presented in Figure 3. Luxemburg remained in the first place, but its GDP per capita increased to 100,000 USD. The reason for this growth, however, is not only a relatively high rate of economic growth of this country, but also the increase in the EUR to USD exchange rate. Switzerland came second (80,000 USD), despite achieving moderate growth. This is primarily the effect of the strengthening of the CHF against the USD. Two countries quit the group of the 19 most-developed countries: they were France (38,000 USD) and Italy (29,000 USD), replaced there by New Zealand (40,000 USD) and Israel (39,000 USD).

In the group of moderately developed countries in 2016, France ranked first (37,000 USD) followed by Italy (29,000 USD). Mexico (4,000 USD) and Turkey (5,000 USD) left the group while Argentina (12,000 USD) and Costa Rica (11,000 USD) joined it. Despite its relatively high rate of economic growth (4.1\%), Poland fell in this classification from position 33 to 38, mainly due to the increase in the USD exchange rate to PLN.

China's very high economic growth rate $(10.4 \%)$ lifted this country from position 49 to 46 . On the other hand, relatively high growth rate in India (8.4\%) and Indonesia $(6.1 \%)$ failed to move these countries from the last and the penultimate place on the list of the OECD richest countries.

As can be seen, national ratings of the S\&P agency in 2016 are strongly correlated with the division of OECD countries proposed by us in terms of GDP per capita into three groups. In the first group of the richest countries, apart from Italy, the grades are in the range of AAA- AA-. Italy's lower rating (BBB-) probably results from high public debt of this country (132\% of GDP). Relatively low ratings of Ireland $(\mathrm{A}+)$ and Iceland are the result of the recession of these two economies during the 2008-2009 crisis.

The ratings of countries in the moderately developed group are more diverse and, except for Greece (B-), located in the range between AA (New Zealand) and BB- (Cyprus). The lowest note of Greece results from the sovereign debt crisis of this country. The lowest ratings were attributed to countries from the least developed group and they are in the BB + (Russian Federation), BBB(India) range. 


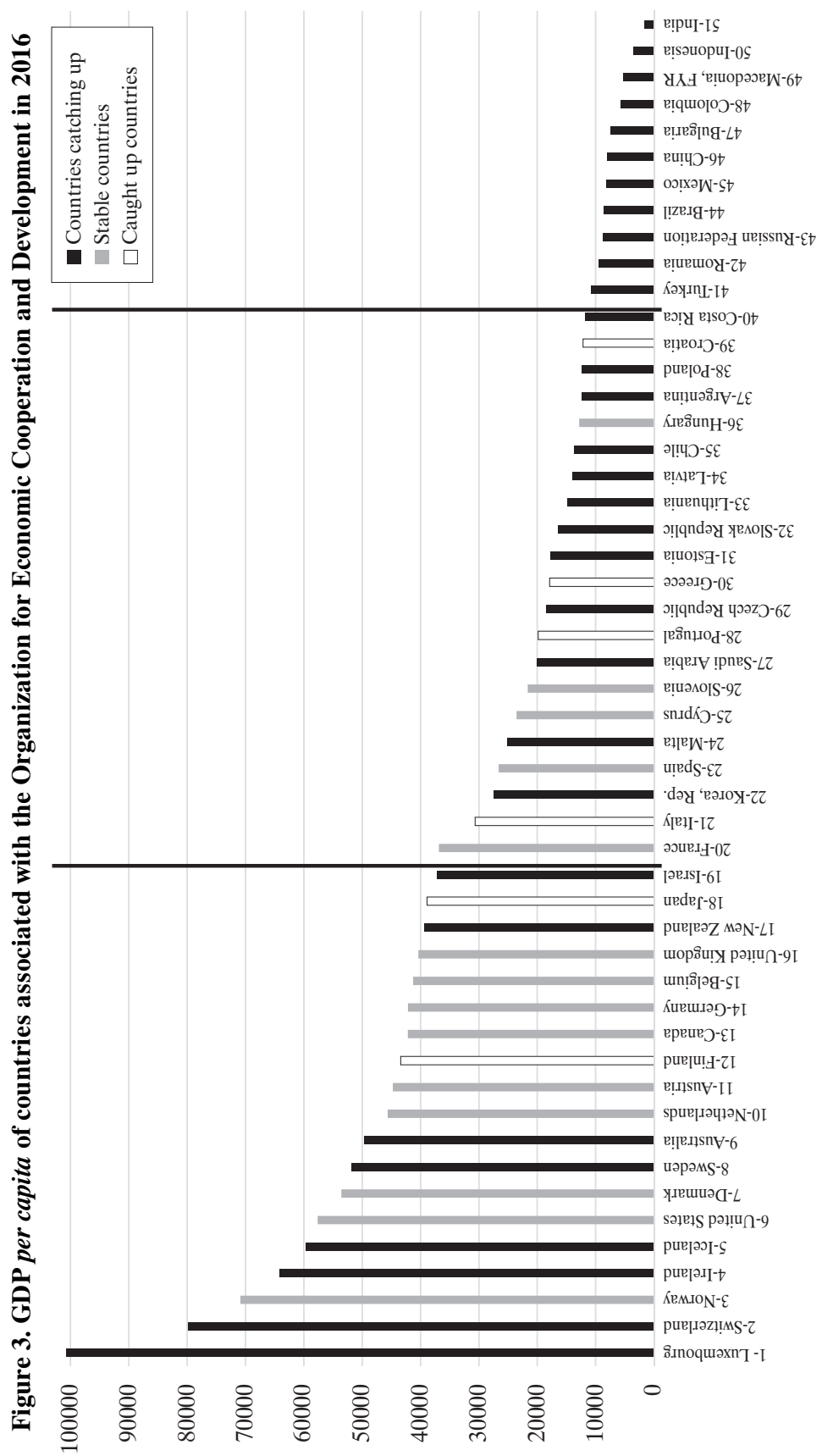




\section{Foreign Direct Investment}

In today's open and globalized economy, its development potential undoubtedly depends on the country's participation in international exchange on all commodity, labor, and financial markets. In particular, we will analyze the global capital flows within the so-called foreign direct investment (FDI). FDIs are compiled and published by central banks.

According to the definition, the IMF and OECD are a category of international investments made by a resident of one country (called „direct investor" or "parent company”) with the intention of exercising long-term control in another country's enterprise (called "direct investment enterprise” or „daughter company”). Long-term control means the existence of a long-term relationship between the direct investor and the daughter company. An important way of impact that gives the direct investor an effective voice in managing the enterprise, depends on the share of the direct investor in the daughter company's capital. The minimum threshold for the equity investor's direct investment in the daughter company is set at $10 \%$.

The FDI components are equity capital, reinvested earnings, and other capital. FDI's share capital is related to:

- purchase of shares, stocks or company assets,

- in-kind contribution, e.g. in the form of machines and devices,

- reinvested profits, part or all of the profits made (proportional to the share of the direct investor in the capital of the company), which was not paid in the form of a dividend.

Other capital is intra-corporate loans and transactions related to servicing this debt. The essence of FDI is the transfer not only of capital but also of labor (e.g. participation of representatives in the daughter company's management board) and knowledge (technological, marketing and organizational).

Foreign direct investment in national balance of payments accounts in the following terms:

- direct domestic investments abroad:

- inflow - shares acquired by residents abroad (shares, assets) + reinvested profits + increase in debt of foreign companies to residents;

- outflow - foreign shares sold by residents (shares - assets) + dividends paid to residents by foreign companies + debt repayment by foreign companies to residents;

- status (stocks) - shares held by residents at the end of the year (quarter) (shares, assets) + unpaid debts of foreign companies in relation to residents. 
- foreign direct investment in the country:

- inflow - shares acquired by foreign entities in the country (shares, assets) + profits reinvested by foreign entities in the country + increase in the debt of domestic companies in relation to foreign entities;

- outflow - shares (stocks, assets) sold by foreign entities + dividends paid by residents to foreign entities + repayment of residents' debt to foreign companies;

- status (stocks) - shares held by foreign entities in the country (shares, assets) + non-paid debts of residents towards foreign entities.

According to the OECD and World Bank definition, in net international statistics the net inflow balance under FDI is the value of direct investments made by foreign investors in the reporting economy. The net outflow balance is the value of direct foreign investments made by residents of the reporting economy on external economies. Direct investments, also referred to as direct investments in the reporting economy, include all liabilities and assets transferred between resident institutions making direct investments and their direct investors. It also includes transfers of assets and liabilities between resident and non-resident enterprises if the ultimate controlling parent is not resident.

External direct investments, also referred to as direct investments abroad, include assets and liabilities transferred between direct investors and their direct investment enterprises. They include transfers of assets and liabilities between resident and non-resident enterprises if the ultimate controlling parent is resident. External direct investments are also referred to as direct investments abroad.

Data on FDI flows are also presented as the balance (FDI net): the difference between the inflow of capital to the reporting country and the outflow of capital from the reporting country (receivables minus liabilities between direct investors and their foreign affiliates). The decrease in the net asset value or the increase in net liabilities is recorded as loans, while the net asset increases or the net decrease in liabilities are recorded as charges. Hence, FDI flows with a negative sign indicate that at least one of the FDI components is negative and is not compensated by positive values of other components. These are cases of reverse investment or disinvestment.

The FDI database published by the OECD covers the value of the annual inflow and outflows of investments to and from individual countries in USD, the value of the annual inflow and outflow of capital in the form of FDI and the share of FDI inflow stream in host countries' GDP and the share of FDI outflow in GDP of countries investing. 
Figure 4. The inflow of direct investments in USD billion

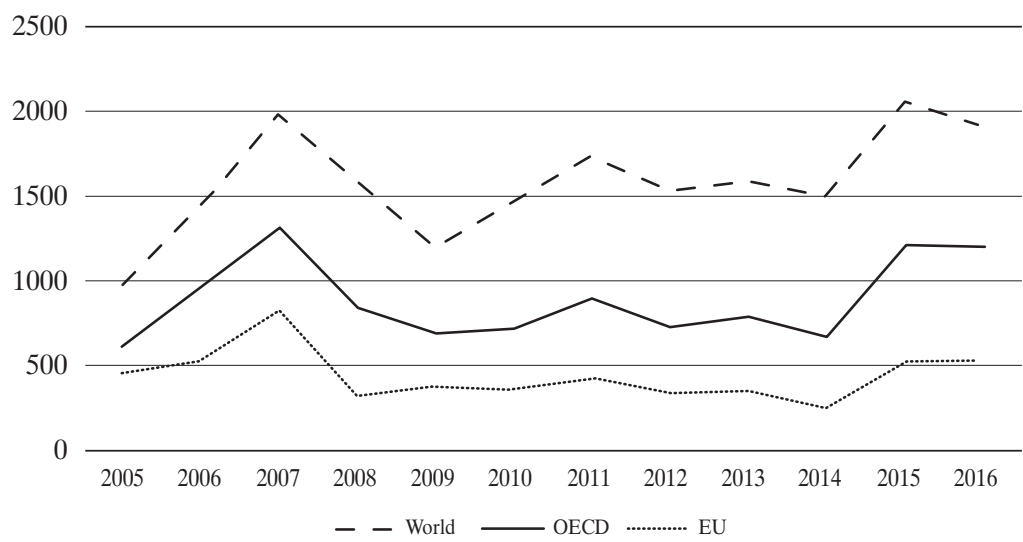

Source: own study based on OECD data (www.oecd.org).

Figure 5. Outflow of direct investment in USD billion

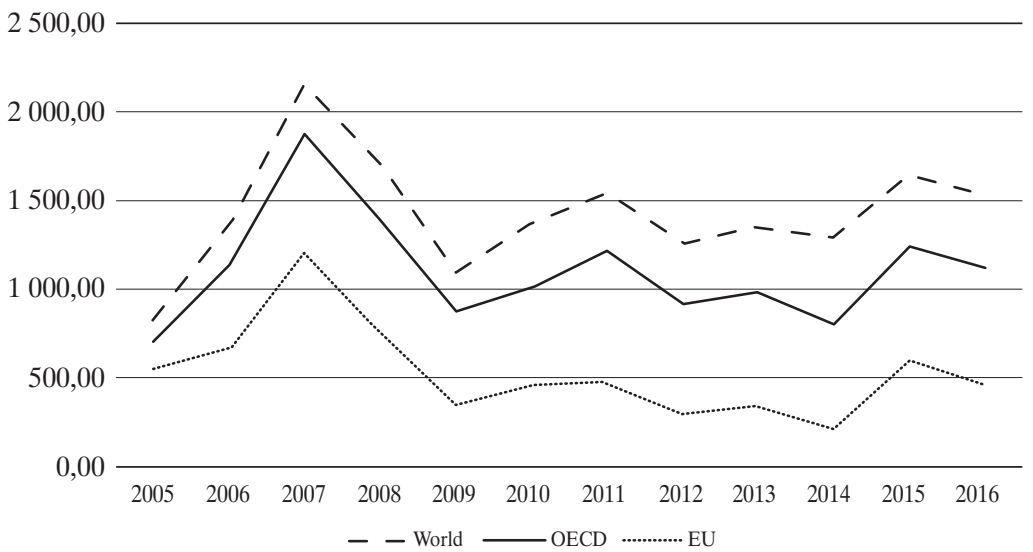

Source: own study based on OECD data (www.oecd.org).

The OECD countries have the largest share in FDI inflow and outflow of capital, while their share in the annual outflow amounts to about $90 \%$ of global outflows, while in annual FDI inflows it is only $62 \%$. It follows from this that OECD countries are more direct providers of direct investments to other countries, while to a lesser extent they are the destination of global direct investments.

L. Alfaro and J. Chauvin (2017) proved in their study that developing economies are growing as a result of an increase in direct investment, at the 
same time creating opportunities and threats for host countries. In their analysis, they used macroeconomic variables (GDP growth rate, aggregated production, exports) and microeconomic ones (positive external effects of side effects, links and reallocation of capital). Economic benefits are diversified in relation to the level of economic development due to the inflow of direct investments. Foreign companies invest capital more often in less-developed economies than in developed economies, where they can raise funds at the local level. Both types of economies are likely to benefit from wage increases and export due to the presence of foreign capital, although potentially it will occur through different channels. In underdeveloped economies, export can increase because foreign companies have smaller financial constraints and can afford a fixed cost of export. In developed economies, instead, export can result from the fact that foreign companies avoid greater competition in local markets. Greater microeconomic benefits resulting from the spread of foreign direct investment, positive links, and competitive pressure are more likely in economies with well-developed financial markets, where local companies can respond to these opportunities and threats due to increased competition through investments that increase their productivity.

Figure 6. Inflow of direct investment as a percentage of GDP

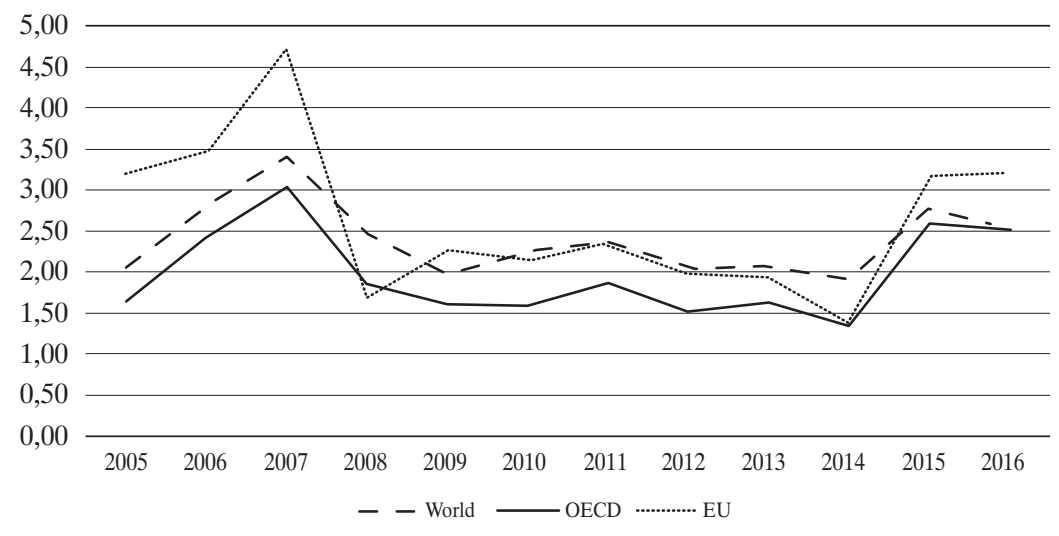

Source: own study based on OECD data (www.oecd.org).

In Figure 6, we show annual inflow streams, and in Figure 7, annual FDI outflows on the global, OECD, and EU scale as a percentage of GDP (respectively: world, OECD, and EU). The FDI within the EU is the most important in relation to GDP. The value of direct investments that flowed into the EU in 2007 was $4.60 \%$ of their GDP, while the value of FDI of EU 
residents abroad accounted for $7.00 \%$ of GDP that year. Thus, EU residents are, to a larger extent, direct investors than recipients of foreign investments. For the OECD countries, the same indicators in 2007 were respectively: FDI inflow $-3.10 \%$ of GDP; FDI outflow $-4.20 \%$ of GDP. So, again, residents of these countries to a greater extent invest abroad than act as beneficiaries of foreign investments. However, the difference is much smaller compared to the EU.

Figure 7. Inflow of direct investment as a percentage of GDP

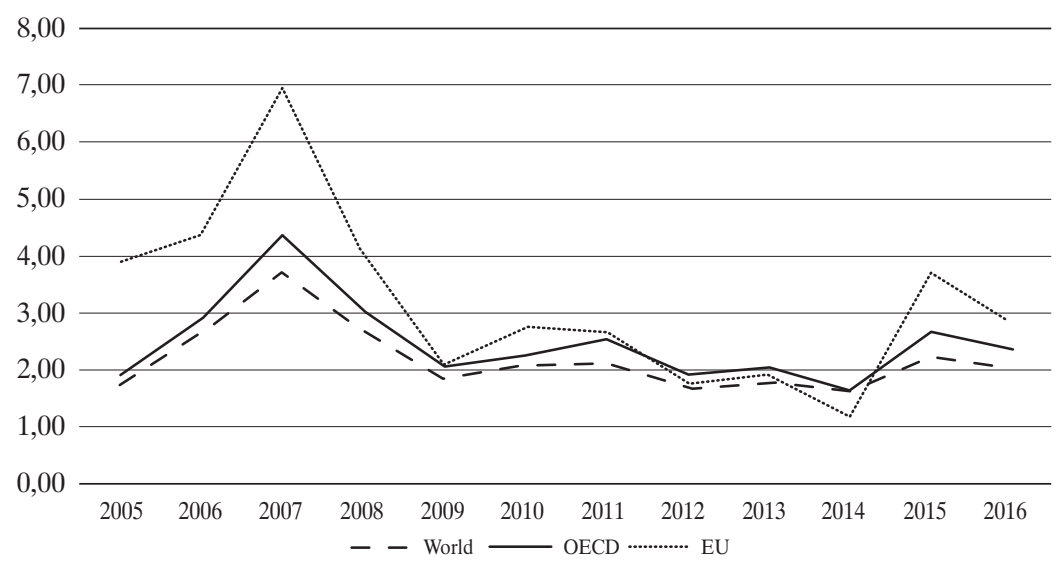

Source: own study based on OECD data (www.oecd.org).

Figure 8. Inflow of direct investment in three groups of OECD countries, taking into account the level of economic development measured by GDP per capita in USD million

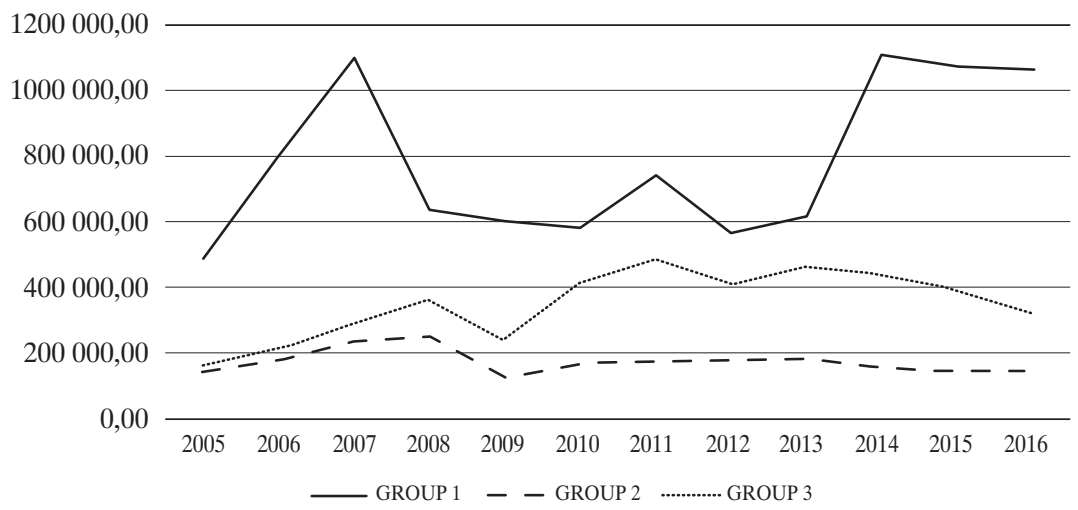

Source: own study based on OECD data (www.oecd.org). 
Figure 9. Outflow of direct investment in three groups of OECD countries, taking into account the level of economic development measured by GDP per capita in USD million

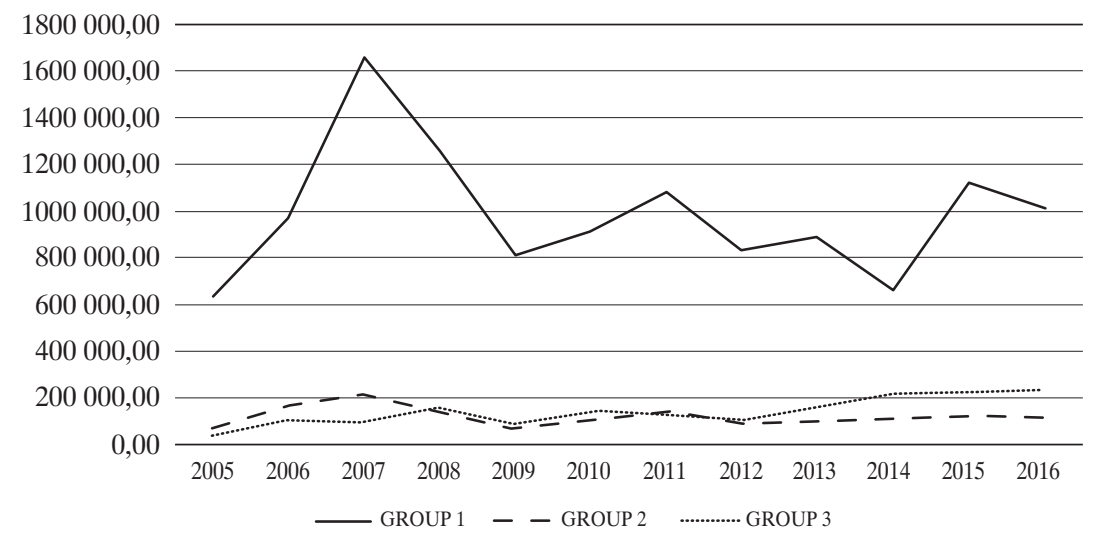

Source: own study based on OECD data (www.oecd.org).

Figure 8 shows the FDI inflow, and Figure 9 shows the outflow of capital from three groups of OECD countries highlighted in the first part of the article (highly developed, moderately developed, and least developed). As before, all streams are reported for the period 2005-2016. It is worth noting that the inflow and outflow of capital under FDI is very sensitive to the global business cycle, phenomenon that cannot be seen in the group of moderately and least developed countries. The FDI inflow increased in the period 2005-2007 from approximately USD 500 billion to USD 1,100 billion. The value of direct investments of residents of OECD countries abroad in 2007 amounted to USD 1.6 billion, which accounted for $84 \%$ of direct investments of the entire OECD and $71 \%$ of global direct investments. The inflow of FDI to OECD countries amounted to USD 1.1 trillion that year, which accounted for $85 \%$ of the FDI inflow to the entire OECD and 55\% of global FDI values that year. The above indicators show that FDI has the primary meaning within the OECD between residents of the 19 most developed countries in the world. Residents of these countries are net exporters to other countries, which is reflected in the negative balance of FDI in this group of countries, shown in Figure 10. In the opposite situation are moderately and least developed countries that have positive FDI balance. A special beneficiary of FDI is the group of the least developed countries, whose FDI balance is almost twice as high as in the group of moderately developed countries. 
In their study R. Caesar and O.R. Escobar (2015) analyzed the links between foreign direct investment and institutional distance ${ }^{3}$. They verified how the institutional distance affects foreign direct investment and showed that institutional distances reduce the likelihood that the company will invest in a foreign country, which is also related to the size of the investment it will make. A study conducted on OECD data indicates that FDI activity decreases with the institutional distance. In addition, they note that companies from developed economies are easier to adapt to institutional distance than companies from developing economies.

Figure 10. Balance of direct investment in three groups of OECD countries, taking into account the level of economic development measured by GDP per capita

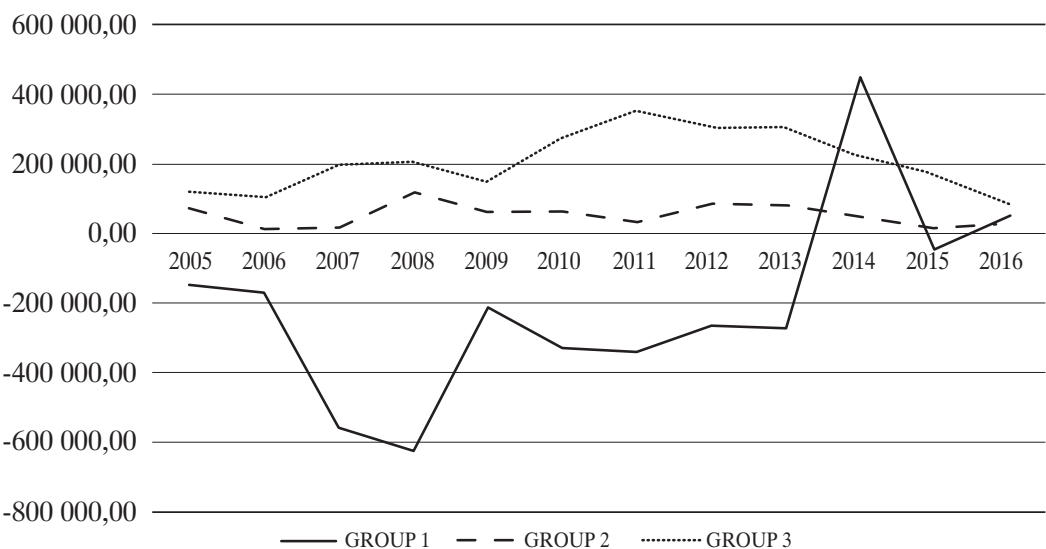

Source: own study based on OECD data (www.oecd.org).

Table 2. The inflow of direct investments from groups I, II and III to groups I and II in USD million

\begin{tabular}{|c|c|c|r|r|r|r|}
\hline $\begin{array}{c}\text { Accepting } \\
\text { countries }\end{array}$ & \multicolumn{2}{|c|}{ GROUP I } & \multicolumn{2}{c|}{ GROUP II } & \multicolumn{2}{c|}{ GROUP III } \\
\hline $\begin{array}{c}\text { Sending } \\
\text { countries }\end{array}$ & GROUP I & GROUP II & GROUP I & GROUP II & GROUP I & GROUP II \\
\hline 2005 & 68341 & 22728 & 11933 & 3156 & 174 & 144 \\
\hline 2006 & 50024 & 20339 & 5902 & 2768 & 3206 & 83 \\
\hline 2007 & 123325 & 28132 & 10864 & 5695 & 906 & 35 \\
\hline 2008 & 60463 & 24204 & -11864 & 6570 & 279 & 282 \\
\hline 2009 & 69549 & 20932 & 2693 & 6074 & -1619 & 329 \\
\hline
\end{tabular}

3 Differences between regulations and regulating institutions. 
continued Table 2

\begin{tabular}{|c|c|c|c|c|c|r|}
\hline $\begin{array}{c}\text { Accepting } \\
\text { countries }\end{array}$ & \multicolumn{2}{|c|}{ GROUP I } & \multicolumn{2}{c|}{ GROUP II } & \multicolumn{2}{c|}{ GROUP III } \\
\hline $\begin{array}{c}\text { Sending } \\
\text { countries }\end{array}$ & GROUP I & GROUP II & GROUP I & GROUP II & GROUP I & GROUP II \\
\hline 2010 & 91608 & 25737 & 2507 & 4938 & -98 & 230 \\
\hline 2011 & 355466 & 78538 & 16896 & 7327 & 1589 & -2103 \\
\hline 2012 & 337360 & 59715 & 15593 & 3251 & 3412 & 303 \\
\hline 2013 & 637943 & 102548 & 77210 & 5694 & 12347 & 1255 \\
\hline 2014 & 398755 & 78380 & 31463 & 13313 & 19822 & 1272 \\
\hline 2015 & 870877 & 40743 & 19141 & 10394 & 1575 & 395 \\
\hline 2016 & 709703 & 116074 & 25188 & 16292 & 7451 & 1071 \\
\hline
\end{tabular}

Source: own study based on OECD data (www.oecd.org).

Table 3. Outflow of direct investments from groups I, II and III to groups I, II and III in million USD

\begin{tabular}{|c|r|r|r|r|r|r|}
\hline $\begin{array}{c}\text { Accepting } \\
\text { countries }\end{array}$ & \multicolumn{2}{|c|}{ GROUP I } & \multicolumn{2}{c|}{ GROUP II } & \multicolumn{2}{c|}{ GROUP III } \\
\hline $\begin{array}{c}\text { Sending } \\
\text { countries }\end{array}$ & GROUP I & GROUP II & GROUP I & GROUP II & GROUP I & GROUP II \\
\hline 2005 & 93999.50 & 83.32 & 24061.65 & 425.89 & 7659.71 & 222.50 \\
\hline 2006 & 131022.97 & 355.27 & 30079.08 & 676.51 & 10372.79 & 134.14 \\
\hline 2007 & 198611.91 & 467.78 & 26477.75 & 1142.08 & 20750.17 & 288.89 \\
\hline 2008 & 87543.86 & 413.61 & 36568.71 & 925.55 & 19596.49 & -83.17 \\
\hline 2009 & 143029.68 & -63.04 & 17421.18 & 2170.64 & 4487.36 & 280.24 \\
\hline 2010 & 129460.87 & 1139.48 & 19266.27 & -139.63 & 6712.58 & $-3,75$ \\
\hline 2011 & 405668.24 & 42001.20 & 21922.29 & 3332.72 & 10119.23 & 194.26 \\
\hline 2012 & 314797.58 & 1647.07 & 35197.69 & 2186.47 & 14596.41 & 428.15 \\
\hline 2013 & 567517.90 & 7785.97 & 79522.83 & 8911.37 & 27716.08 & 878.87 \\
\hline 2014 & 491038.61 & 24053.40 & 59599.13 & 21673.86 & -96.58 & 971.46 \\
\hline 2015 & 774445.08 & 8577.26 & 36172.76 & 8936.24 & 15702.54 & 1980.20 \\
\hline 2016 & 676821.75 & 97956.83 & 72499.14 & 6566.18 & 9926.59 & 33.81 \\
\hline
\end{tabular}

Source: own study based on OECD data (www.oecd.org).

Research of M. Irandoust (2016) conducted among the Baltic countries between FDI and structural changes has shown that by promoting growth and structural reforms, beneficiary countries can encourage the inflow of foreign 
direct investment, which in turn may affect their growth. They also indicated the existence of a feedback between these two variables.

The analysis conducted is consistent with the assumptions of the new structural economics (Lin, 2010; 2012). It turned out that, depending on the level of economic development, the optimal industrial structure is changing. The form of the inflow of direct investment funds from the point of view of the economy is also changing. In the current situation, it can be presumed that, depending on the level of economic development, countries should invest in both "soft" and "hard" infrastructure. At the same time, according to the assumption of the theory, it can be presumed that in the process of continuity there is a continuous economic growth presented by us as the "race of countries" theory. The change depending on the type of sector in which direct investments are made causes gradual economic growth. Therefore, countries should adapt their investments in a given sector depending on the level of their economic development. In addition, the impact of the financial crisis on the allocation of direct investment in individual economies shows that at each given stage of development, the market is the basic mechanism for effective allocation of resources. As a result, along with the economic growth, according to the New Structural Economics, the economies require industrial modernization and appropriate improvements in the "hard" and "soft" infrastructure at every stage. Such modernization entails significant external effects on the transaction costs of companies and returns on capital investments. Therefore, in addition to an effective market mechanism, the government should play an active role in facilitating industrial modernization and infrastructure improvements.

The research conducted indicates two economies that are especially interesting in this respect, i.e. China and India, both peculiar due to their size and very fast growth. R. Dekle and G. Vandenbroucke (2012, p. 119-135) investigated the structural transformation in China in 1978-2003. They found that the diversified sectoral increase in productivity and the reduction in the relative size of the Chinese government caused most of the structural transformation but slowed down the movement in agriculture. V. Rubina (2012, p. 163-177) investigated the structural transformation in India in 1980-2005 and found that the growth was fastest in services. She proved that the three-sector model could take into account changes in sectoral value added, but not in employment shares. C.M. Betts et al. (2011), M. Sposi (2011) and Teignier (2012) argue that international trade has accelerated the transition of the economy from agriculture to industry and services. Teignier (2012) has proven that the effect of international investment would have played an even greater role if South Korea did not introduce a policy of agricultural protection at the same time. 
Work of D.W. Jorgenson and M.P. Timmer (2011, p. 1-29) based on the study of the European Union, Japan, and the USA shows a significant heterogeneity of services. Finance and business services are characterized by low productivity growth and increase the share in employment and GDP, while distribution services have rapid increase in productivity and constant participation. M. Duarte and D. Restuccia (2010, p. 129-173) studied the differences between traditional ${ }^{4}$ and non-traditional services. In the case of traditional services, they notice that the relative price increases and the real share of expenses decreases with revenues, while in the case of non-traditional services the opposite occurs. D. Lagakos and M.E. Waugh (2013, p. 948-980) argue that the inclusion of heterogeneous quality of work in different sectors proves that poor countries seem to have particularly low productivity in agriculture.

B. Herrendorf, R. Rogerson, A. Valentinyi (2014, p. 855-941) indicate that inadequately selected structural policies may distort the allocation of resources in various sectors. In accordance with the new structural economics, structural transformation should strive to use state intervention to develop specific sectors with the greatest potential for development (Ketels, 2017). Assumptions about profitability in neoclassical economics can be eased by analyzing issues of development and transformation in socialist, transformational, and developing economies (Lin, 2015).

Figure 11. Balance of direct investment by sector in the first group of countries in USD million

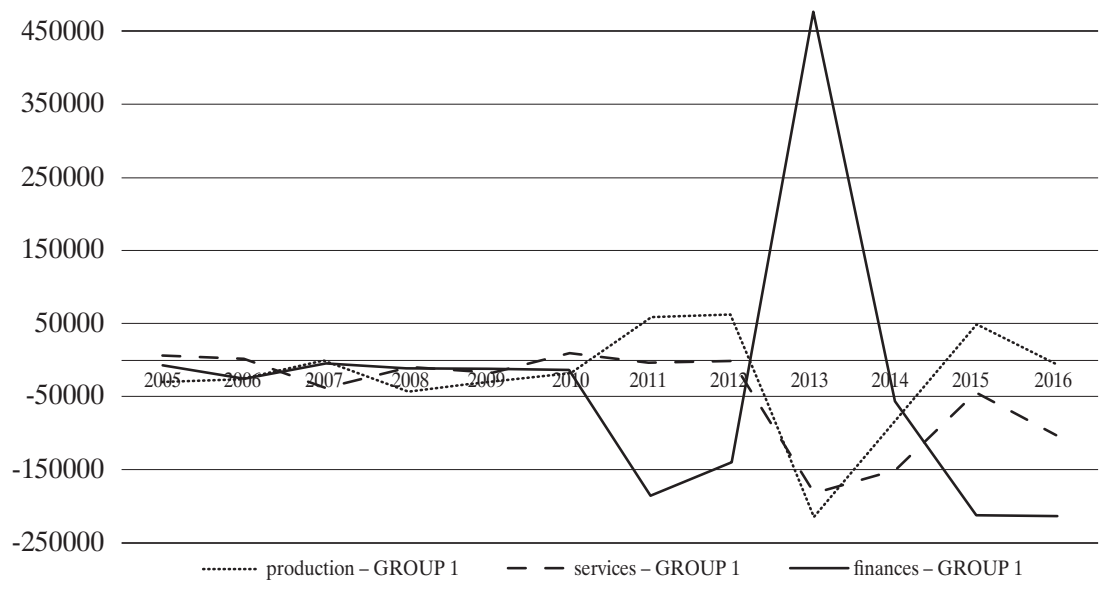

Source: own study based on OECD data (www.oecd.org).

4 I.e. traditional services such as home services and education, health, housing, and nontraditional services including communication, transport, insurance and financial services as well as recreational and cultural services. 
Figure 12. Balance of direct investment by sector in the second group of countries in USD million

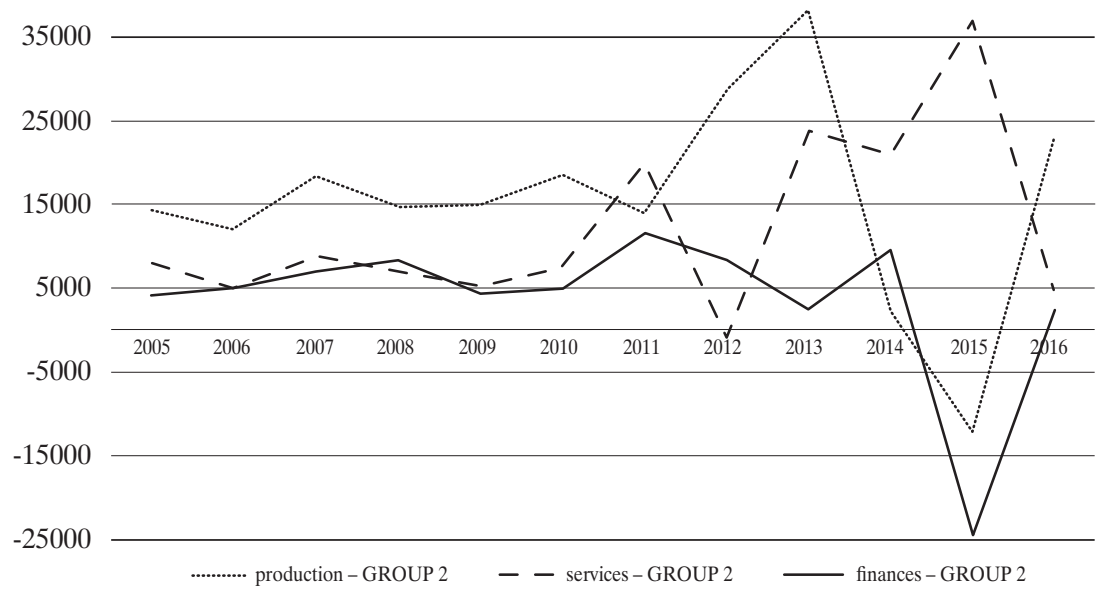

Source: own study based on OECD data (www.oecd.org).

Next, it was decided to verify the mutual relations between the balance of direct investment and the real rate of GDP growth and vice versa. To verify this relationship, annual data from the World Bank for the years 1970-2017 was collected for 165 countries. Static panel models were used for the study. The Hausman-Breusch-Pagan test was used to verify the correctness of the model selection. The choice of the panel model was dictated by simultaneously having the features of cross-sectional data, i.e. data for countries and time series. The model presenting the impact of the real GDP growth rate on the balance of direct investments to GDP is as follows:

$$
f d i_{i t}=\alpha+p k b_{i t}+u_{i t}+e_{i t}
$$

$f d i_{i t}$ - the ratio of direct investment to GDP in the $i$-th country in period $t$, $p k b_{i t}$ - real GDP growth rate of the $i$-th country in period $t$, $\alpha$ - constant, $u_{i t}$ - a random error containing time-constant unobserved characteristics, $e_{i t}$ - purely random error.

The model revealing the impact of the direct investment balance on the real GDP growth rate is presented below:

$$
p k b_{i t}=\alpha+f d i_{i t}+u_{i t}+e_{i t}
$$


Table 4 presents the results of the estimation.

Table 4. Results of estimation of the impact of the real GDP growth rate on the balance of direct investment (1) and the balance of direct investments on the real GDP growth rate

\begin{tabular}{|c|c|c|c|c|}
\hline \multirow{2}{*}{ Dependent variable } & \multicolumn{2}{|c|}{ FDI net (1) } & \multicolumn{2}{|c|}{ Real GDP growth rate (2) } \\
\hline & Coef. & P> the & Coef. & P> the \\
\hline \multirow[t]{2}{*}{ Independent variable } & .123695 & 0.000 & .0306341 & 0.000 \\
\hline & 3.500842 & 0.000 & 3.704615 & 0.000 \\
\hline Number of observations & \multicolumn{2}{|c|}{5911} & \multicolumn{2}{|c|}{5911} \\
\hline Number of groups & \multicolumn{2}{|c|}{165} & \multicolumn{2}{|c|}{165} \\
\hline $\mathrm{F}$ test & \multicolumn{2}{|c|}{0.0000} & \multicolumn{2}{|c|}{0.0000} \\
\hline Hausman & \multicolumn{2}{|c|}{0.1306} & \multicolumn{2}{|c|}{0.1947} \\
\hline $\mathrm{BP}$ & \multicolumn{2}{|c|}{0.0000} & \multicolumn{2}{|c|}{0.0000} \\
\hline \multicolumn{5}{|l|}{$\mathrm{R}$ squared } \\
\hline Inside & \multicolumn{2}{|c|}{0.0034} & \multicolumn{2}{|c|}{0.0034} \\
\hline Between & \multicolumn{2}{|c|}{0.0240} & \multicolumn{2}{|c|}{0.0240} \\
\hline Total & \multicolumn{2}{|c|}{0.0070} & \multicolumn{2}{|c|}{0.0070} \\
\hline Model & \multicolumn{2}{|c|}{ with variable effects } & \multicolumn{2}{|c|}{ with variable effects } \\
\hline
\end{tabular}

Legend: number of groups - number of countries analyzed; test F - Fisher test; Hausman - Hausman test; BP - Breusch - Pagan test; R squared - corrected: inside - corrected inside a group of countries; between - corrected between groups of countries; total - total adjusted.

Source: own study.

The results of the estimation carried out for the Hausman test suggest the correctness of the use of a static panel model with variable effects. However, the results obtained for the Bresuch-Pagan test indicate the appropriateness of using a panel model for the linear model in both cases. Being aware of the poor fit of the model, we do not perform a direct analysis of the results. Our goal was only to verify the significance of mutual dependencies between the balance of direct investment and the real rate of GDP growth and vice versa. The study proved a statistically significant relationship between the two variables. The low level of model matching should be explained by the impact of other significant factors affecting both the balance of direct investment and the real GDP growth rate. The simulation results obtained are consistent with research by C.K. Volos, I.M. Kyprianidis, I.N. Stouboulos (2015, p. 1-7).

K. Dellis, D. Sondermann, I. Vansteenkiste (2017) pointed to the impact of structural changes, such as labor costs, the size of the target market (according to its value), economic activity, openness of trade of the beneficiary country and its tendency to tax. S. Estrin and M. Uvalic (2013) proved that, taking into 
account the size of an economy, distance, institutional quality and prospects of EU membership, the countries of the Western Balkans are characterized by a lower inflow of foreign direct investment. These issues have a high political significance for the Balkan economies.

We are fully convinced that foreign direct investment is not the only or even the main factor influencing economic growth, as well as that the rate of economic growth does not fully determine the inflow and outflow of these investments. This is evidenced by low multiple correlation coefficients in both presented models. Our goal, however, was not to completely explain the determinants of these two variables - for that purpose multifactorial models should be used. However, both univariate models prove the hypothesis of the existence of positive feedback between these variables. The inflow of direct investments positively affects the rate of economic growth, and economic growth encourages foreign investors to invest. This means that FDI operate pro-cyclically. They support economic growth, but also deepen recessions and decrease in GDP. If the slowdown or decline in the economic growth rate occurs as a result of internal or external shocks, the reaction of foreign investors deepens this decline. This phenomenon occurred very clearly in 2018 in the case of Argentina and Turkey.

This phenomenon has already been observed in the relation of bank loans and economic growth. Under Basel III, special counter-cyclical capital buffers were introduced to calculate the solvency coefficient, to counter the pro-cyclical nature of loans. However, unlike the banking sector, FDIs are not regulated by countries of origin or host countries.

\section{References}

Alfaro, L. and Chauvin, J. (2017). Foreign Direct Investment, Finance, and Economic Development. Harvard Business School Working Papers.

Betts, C.M., Giri, R. and Rubina, V. (2011). Trade, Reform, and Structural Transformation in South Korea. University of Southern California Working Paper.

Cezar, R. and Escobar, O.R. (2015). Institutional Distance and Foreign Direct Investment. Banque de France, December.

Dekle, R. and Vandenbroucke, G. (2012). A Quantitative Analysis of China's Structural Transformation. Journal of Economic Dynamics and Control, 36, 119-135.

Dellis, K., Sondermann, D. and Vansteenkiste, I. (2017). Determinants of FDI inflows in advanced economies: Does the quality of economic structures matter? European Central Bank Working Paper, No. 2066.

Duarte, M. and Restuccia, D. (2010). The Role of the Structural Transformation in Aggregate Productivity. Quarterly Journal of Economics, 125, 129-173. 
Estrin, S. and Uvalic, M. (2013). Foreign direct investment into transition economies: Are the Balkans different? London School of Economics Europe in Questions Working Paper, No. 63.

Herrendorf, B., Rogerson, R. and Valentinyi, A. (2014). Growth and Structural Transformation. Handbook of Economic Growth, 2, 855-941.

https://data.oecd.org

Irandoust, M. (2016). Structural changes, FDI, and economic growth: evidence from the Baltic states. Journal of Economic Structures, 5(14).

Jorgenson, D.W. and Timmer, M.P. (2011). Structural Change in Advanced Nations: A New Set of Stylised Facts. Scandinavian Journal of Economics, 113, 1-29.

Ketels, C. (2017). Structural transformation: a competitiveness-based view. African Development Bank Group Working Papers, No. 258.

Lagakos, D. and Waugh, M.E. (2013). Selection, Agriculture, and Cross-Country Productivity Differences. The American Economic Review, 103(2), 948-980.

Lin, J.Y. (2010). New Structural Economics A Framework for Rethinking Development. World Bank Policy Research Working Paper, No. 5197.

Lin, J.Y. (2012). New Structural Economics. A Framework for Rethinking Development and Policy. World Bank.

Lin, J.Y. (2017). New Structural Economics and 2017 industrial policies catching-up economics. W: J.Y. Lin, A.Z. Nowak (ed.), New Structural Economics for less advanced countries. Warszawa: Wydawnictwo Naukowe Wydziału Zarządzania UW.

Lin, J.Y. (2015). The Washington Consensus revisited: a new structural economics perspective. Journal of Economic Policy Reform, 18.

Rubina, V. (2012). Can Total Factor Productivity Explain Value Added Growth in Services. Journal of Development Economics, 99, 163-177.

Sposi, M. (2011). Evolving Comparative Advantage, Structural Change, and the Composition of Trade. University of Iowa Working Paper.

Teignier, M. (2012). The Role of Trade in Structural Transformation. Universidad de Alicante Working Paper.

Volos, C.K., Kyprianidis, I.M. i Stouboulos, I.N. (2015). The Effect of Foreign Direct Investment in Economic Growth from the Perspective of Nonlinear Dynamics. Journal of Engineering Science and Technology Review, 8(1), 1-7. 


\section{Legal Environment for Foreign Investments in Poland}

Free movement of capital and free movement of broadly understood goods and services has been exercised by nation states through several legal instruments which both determine and reflect a level of a given state's openness to involvement of foreign business entities therein. Specifically, such instruments regulate an extent to which foreign firms may undertake and carry on business activities, employ people, make investments, trade in real estates, trade in foreign currencies, etc. The body of legal regulations making regulatory framework for business activity of foreign entities within a given country has been an element which defines the level of access to that specific market, the level of its internationalization and liberalization. The aim of this article is to analyze regulations of Polish law in the area of legal conditions of undertaking and running business activities on the territory of the Republic of Poland by foreign persons and businesses. The subject is especially topical nowadays, in the context of changes brought in that area by the recent Business Constitution.

Keywords: Foreign Person; Foreign Business; Business Activity; Cross-border Provision of Services; Business Constitution.

\section{Introduction}

The phenomenon of free movement of products, technologies, capital as well as of free movement or relocation of institutions, businesses and individuals has been one characteristic element of international integration, closely related with the evolving process of internationalization of socio-economic relations in terms of markets, industries and enterprises. As a consequence of market operation on the global scale, barriers in the global economy are increasingly lifted, in particular in international trade. At the same time, restrictions regarding the movement of capital and financial assets are also gradually abolished. In this context, to eliminate obstacles to foreign direct investments (FDI) so that foreign business entities might compete with domestic ones on equal terms has been one of the key trends evident in the global economy (Nowak, 2017, p. 19-20; Kotyński, 2005, p. 9ff.; Hejduk and Bakalarczyk, 2013, p. 11ff). Thanks to the 
process of globalization and international treaties in the area of free trade, nation states open up to trade exchange and to foreign investments and the principle of free trade makes one of the fundaments upon which the European Community operates (Nowak, 2017a, p. 27). According to the preamble of the Directive of the European Parliament and of the Council on services in the internal market (OJ L 376 of 27.12.2006), the European Community is seeking to forge ever closer links between the States and peoples of Europe and to ensure economic and social progress. In accordance with the provisions of the Treaty establishing the European Community ${ }^{1}$, the internal market comprises an area without internal frontiers in which the free movement of services is ensured as is the freedom of establishment and freedom to provide services within the Community. A competitive market in services is reckoned essential in order to promote economic growth and create jobs in the European Union. The preamble also states that at present numerous barriers within the internal market prevent providers, particularly small and medium-sized enterprises (SMEs), from extending their operations beyond their national borders and from taking full advantage of the internal market. This weakens the worldwide competitiveness of European Union providers. A free market which compels the Member States to eliminate restrictions on cross-border provision of services, while at the same time increasing transparency and information for consumers, would give consumers wider choice and better services at lower prices ${ }^{2}$.

An increased scale of international trade in services results from the processes of deregulation, much intensified in the era of globalization, as well as from technological progress and from quantitative growth of the middle class in emerging economies and developing countries (Budnikowski, 2017, p. 29). The process of globalization heralds an entry into a new qualitative stage of internationalization of business activities, occurring in terms of markets, sectors and businesses (Budnikowski, 2017, p. 599). Then, from the point of view of internationalization of economic relations, the issue of lifting barriers hindering foreign investments in a given country is of crucial importance as they enable the economy to decrease international disproportions in capital endowment. Foreign investments, while not exerting uniform influence across all indexes of general economic condition, still constitute one of driving forces behind the economic growth, certainly contributing to the accrual of any economy's capital resources, which then translates into its increased productivity and higher

\footnotetext{
At present the Treaty on the Functioning of the European Union (TFEU).

2 Directive 2006/123/EC of the European Parliament and of the Council of 12 December 2006 on services in the internal market (OJ L 276 of 27.12.2006), also referred to as the services directive.
} 
wages, as well as improved access to modern technologies (Mankiw and Taylor, 2016, p. 80; Burda and Wyplosz, 2013, p. 171; Begg, Vernasca, Fischer and Dornbusch, 2014, p. 480ff). Another aspect that should be emphasized here is the role of increasing foreign investments and foreign capital as an instrument which facilitates overcoming the global financial crisis in the world's economies over a couple of recent years (Nowak, 2015, p. 590).

Free movement of broadly understood services has been exercised by states using a variety of legal instruments which determine an extent to which a given country's economy is open to entry and involvement of foreign entities therein (more about the entities of global economy - see: Orłowska and Żołądkiewicz, 2012, p. 42ff), including, in particular, their right to undertake and run business activities, to employ people, to make investments, to trade in real estates and in currencies, etc. (Budnikowski, 2017, p. 36). Indeed, the body of legal regulations making regulatory framework for business activity of foreign entities within a given country has been an element which defines the level of access to that specific market, the level of its internationalization and liberalization. The regulatory framework defined by the regulator provide the basis for an analysis of an economy in economic terms and define the course for the state's economic policy in this area.

\section{The Business Constitution}

On 30 April 2018 a set of acts entered into force in Poland, defined as the Business Constitution and introducing a profound reform of Polish commercial law. Changes brought by the Business Constitution have been the farthest-reaching, most extensive reconstruction of business environment in which entrepreneurs operate in the Polish market since 1989. The aim of the reform is to improve legal-and institutional conditions of running business activity and to achieve this through proper realization of the constitutional freedom of involvement in commercial activity and through provision of partner relation between business entities and the state (including the rule according to which "everything that is not forbidden by law is allowed", the clause of legal certainty, the rule of presumption of a business entity's fairness, the rule of resolving factual doubts in its favor, friendly interpretation of provisions of law, the rule of resolving legal doubts in favor of an entrepreneur, rules of trust consolidation, of proportionality, impartiality and equal treatment, and, last but not least, the principle of responsibility of officers of public administration 
for the infringements of law, the rule of certainty of law and predictability of solutions made by the state administration bodies, their collaboration in order to achieve complete clarification of a business entity situation, and rendering the communication between an office and a business entity less formal). Another aim of the Business Constitution is to support business, including the provision of friendly legal conditions for starting business activity, reduction of grey economy, provision of institutional support for entrepreneurs through the appointment of the Spokesperson for Small and Medium-sized Entrepreneurs. At the core of the reform there is a new act - The Business Law ${ }^{3}$, replacing a previous act hitherto in force, on the freedom of commercial activity 4 . The new act systematically defines the fundaments of Poland's economic system, providing a set of basic rules regarding business activity. It specifies legal condition of business and the state's obligations towards it. Detailed reforms brought by the Business Law were extensively reported; most noteworthy among them being simplifications for small business and for persons only initiating their business activities. Small commercial activity may be run freely, without the obligation of having it inscribed into the Central Records and Information on the Commercial Activity; persons running such activity are no longer attributed Regon (national business register) number. Individuals only initiating their business activity are released for the period of six months from the duty to pay social insurance contributions. The Act introduces simplified solutions in the area of rationing of business activity. Any previously released approvals or licenses as separate forms of rationing are waived, with only three forms of restrictions remaining: the activities which require business license, activities which require permission and regulated business activities. Also important are changes limiting the control over business activity.

Apart from the new Business Law, the Business Constitution also includes the Act on the Spokesperson for Small and Medium-sized Entrepreneurs 5 , the Act on the Central Records and Information on the Commercial Activity and Information Point for Entrepreneurs ${ }^{6}$, the Act on provisions implementing the

3 The Act of 6 March 2018 - Business Law (Polish Journal of Law 2018, item 646).

4 The Act of 2 July 2004 on the freedom of commercial activity (Polish Journal of Law 2017, item 2168 with later amendments), overruled by the Act of 6 March 2018 - Provisions implementing the Act - Business Law and other acts regarding commercial activities (uniform text: Polish Journal of Law 2018, item 650).

5 The Act of 6 March 2018 on the Spokesperson for Small and Medium-sized Entrepreneurs (Polish Journal of Law 2018, item 648).

6 The Act of 6 March 2018 on the Central Records and Information on the Commercial Activity and Information Point for Entrepreneurs (Polish Journal of Law 2018, item 647 with later amendments). 
Business Law as well as other acts regarding the commercial activity7. Moreover, which is of particular importance from the point of view of the present analysis - it also contains the Act on the principles of foreign entrepreneurs' and other foreign persons' participation in trade on the territory of the Republic of Poland 8 .

The former principles concerning business activity run by foreign persons on the territory of Poland were dispersed across several legal acts. As a consequence, the legislative technique used resulted in poor transparency as regards the key conditions for foreign businesses' operation in domestic trade in Poland. Such conditions had been set forth by the Act on the freedom of business activity, the act on the provision of services on the territory of the Republic of Poland ${ }^{9}$, the act setting the rules of running, on the territory of the People's Republic of Poland, commercial activity in the area of small manufacturing by foreign legal persons and individuals ${ }^{10}$. The new Act on the principles of foreign entrepreneurs' and other foreign persons' participation in trade on the territory of the Republic of Poland (further on referred to as the Act) integrates within a single legal act all legal regulations hitherto in force, doing it in a comprehensive and consistent manner, specifying the conditions of foreign entrepreneurs' participation in trade in Poland. In effect of the integrating reform, all these rules have become clearer, more accessible and comprehensible to foreign persons interested in making investments on the territory of Poland. With its scope of regulation, the Act in question implements the Directive 2006/123/EC of the European Parliament and of the Council of 12 December 2006 on services in the internal market.

7 The Act of 6 March 2018 - Provisions implementing the act - Business Law and other acts regarding commercial activity (Polish Journal of Law 2018, item 650).

8 The Act of 6 March 2018 on the principles of foreign entrepreneurs' and other foreign persons' participation in trade on the territory of the Republic of Poland (Polish Journal of Law 2018, item 649 with later amendments).

9 The Act of 4 March 2010 on the provision of services on the territory of the Republic of Poland (Polish Journal of Law 2016, item 893 with later amendments), overruled by the Act of 6 March 2018 - Provisions implementing the act - Business Law and other acts regarding the commercial activity (uniform text: Polish Journal of Law 2018, item 650).

10 The Act of 6 July 1982 setting the rules of running, on the territory of the People's Republic of Poland, commercial activity in the area of small manufacturing by foreign legal persons and individuals (Polish Journal of Law 1989, item 27 with later amendments), overruled by the Act of 6 March 2018 - Provisions implementing the act - Business Law and other acts regarding the commercial activity (uniform text: Polish Journal of Law 2018, item 650). 


\section{The Principles of Running Commercial Activity in Poland by Foreign Persons and Business Entities}

\subsection{Legal and Organizational Forms and Conditions for Running Commercial Activity}

Foreign persons from member states of the European Union or of the European Free Trade Association (EFTA) - parties of the European Economic Area agreement (EEA member states) may undertake and run commercial activity on the territory of the RP on the same rules as citizens of Poland. Foreign person is understood as an individual not having Polish citizenship, a legal person having its domicile abroad or an organized entity which is not a legal person possessing legal capacity, having its domicile abroad. This rule concerns legal entities irrespective of their legal and economic status in their member state of origin.

A similar rule concerns the citizens of third (non-member) states if they meet the conditions defined in Article 4(2) of the Act (especially where they possess permission for permanent stay on the territory of the RP, long-term EU-resident permit, temporary stay permit given on specified terms, a refugee status, subsidiary protection, if they benefit from temporary protection in the RP, possess valid Polish Charter, etc.).

Other foreign persons may undertake and run commercial activity on the territory of the RP only in the form of a limited partnership, limited joint-stock partnership, limited liability company or a joint-stock company. They may also join such entities and take up or acquire their shares or stock, unless relevant international agreements provide otherwise. It should be emphasized in this context that the types of business entities listed above are persons under Polish law, operating pursuant to Polish legislation. The Act excludes the possibility of undertaking or running, by that category of foreign persons, commercial activity on the territory of the RP in any other organizational and legal form than specified, e.g. in the form of general partnership or professional partnership. Joining such business entities is forbidden as well.

It should also be remembered that either taking up or acquiring shares or stock by a foreign person in a commercial company having its domicile on the territory of the RP, as well as any other legal act concerning shares or stock, requires a permit to be given by a minister competent for home affairs, where such act results in the company being an owner or perpetual user of a real estate situated on the territory of the RP becoming a controlled company. Where a commercial company having its domicile on the territory of the RP, 
being an owner or perpetual user of a real estate situated on the territory of the RP, is a controlled company in the first place and its shares or stock are acquired by a foreign person not being its shareholder already, such an act also requires a permit given by a minister competent for home affairs. The above rule results from the principle, adopted in the Polish law, requiring a permit from a minister competent for home affairs, for an acquisition by a foreign person of the right of ownership of a real estate or the right of its permanent use, on the basis of any legal occurrence ${ }^{11}$. As understood by the provisions of the Act on the acquisition of real estates by foreign persons, a foreign person is an individual not possessing Polish citizenship, a legal person having its domicile abroad, a partnership of such persons not having legal personality, having its domicile abroad, established pursuant to foreign states' legislation, as well as a legal person or a commercial company having its domicile on the territory of the RP, either directly or indirectly controlled by the above-mentioned persons or companies. The Act on the acquisition of real estates by foreign persons provides for a number of exemptions from the obligation of obtaining a permit, the most important of which is the exemption from the duty to obtain such permit by foreigners who are citizens or entrepreneurs of the states-parties to the European Economic Area agreement (EEA) or of the Swiss Confederation.

Foreign entrepreneurs from member states (i.e. foreign persons involved in commercial activity in a member state) may set up branches on the territory of the RP. A branch is established exclusively to run business activity on the territory of the RP in the area in which such foreign entrepreneur runs that business activity abroad. Foreign entrepreneurs from countries other than member states may set up branches on the principle of reciprocity, unless relevant ratified international agreements prevent so. A branch set up by a foreign entrepreneur is subject to registration in the Business Register at the National Court Register.

The hitherto-existing principle of no separate legal personality of a foreign entrepreneur's branch in the light of provisions of Polish law has been retained. Hence, a branch constitutes a separated and organizationally autonomous part of the business activity run by a foreign entrepreneur and it operates under the legal personality of that foreign person. Accordingly, the provisions of law require that a foreign entrepreneur who sets up a branch on the territory of the RP also appoint a person authorized in that branch to represent him.

11 The Act of 24 March 1920 on the acquisition of real estates by foreign persons (uniform text: Polish Journal of Law 2017, item 2278). 
According to Article 39(4) of the Act on the National Court Register ${ }^{12}$, such person authorized by a foreign entrepreneur to represent him in the branch has to be explicitly named in the business register.

The new regulation limited the obligation to perform liquidation proceedings, under a procedure and pursuant to rules defined in the provisions of the code of commercial companies concerning a limited liability company liquidation, only to one situation in which a foreign entrepreneur's branch is liquidated in effect of a decision, issued by a minister competent in a given field, on the prohibition of carrying on of a business activity, through a branch, by a foreign entrepreneur. The procedure, defined under the Act, under which a competent minister issues such decision prohibiting business activity being run by a foreign entrepreneur via a branch, does not relate to foreign entrepreneurs from the Community members states. Where a foreign entrepreneur decides on his own to liquidate his branch, then - unlike in previous regulations in this respect - he is no longer obliged to carry on the liquidation proceedings under a procedure and pursuant to rules defined in the provisions of the Code of Commercial Companies concerning a limited liability company liquidation.

A foreign entrepreneur may establish, on the territory of the RP, his representations, whose scope of operation is strictly limited to activities in the field of advertising and promotion of the foreign entrepreneur concerned. Such representation may not be exploited by that foreign entrepreneur to run any commercial activity on the territory of Poland. The establishment and running a business representation requires an entry to be made to the register of foreign enterprises' representations. Quite importantly, such an entry to the register is made for a period of validity of two years since the entry date. Then, upon the foreign entrepreneur's motion the relevant entry may be extended to another period of two years.

In that context it should be added that although the Act on the principles of foreign entrepreneurs' and other foreign persons' participation in trade on the territory of the Republic of Poland has comprehensive character and manages to integrate various provisions of law previously dispersed across many legal acts, still isn't the only source of law specifying the organizational and legal conditions for foreign entities' activity in trade in Poland. What remains beyond its scope is, among other things, the provisions defining the procedures of cross-border mergers of shareholding companies and limited

12 The Act of 20 August 1997 on the National Court Register (uniform text: Polish Journal of Law 2018, item 986 with later amendments). 
joint-stock partnerships (these being regulated under the provisions of the Code of Commercial Companies $\left.{ }^{13}\right)$.

\subsection{Cross-border Provision of Services}

The Act on the principles of foreign entrepreneurs' and other foreign persons' participation in trade on the territory of the RP incorporates the provisions defining the conditions of running cross-border services provision. The pivotal issue from the point of view of that regulation is the notion of "service". This is defined in Article 3(8) of the Act as service performed by a service provider from a member state on its own account, usually against remuneration, including, in particular, construction services, trade services and services provided within the scope of the profession performed. Leaving out the fact that this definition is obviously flawed as it commits the logical idem per idem error ("services are (...) services"), its wording calls for a couple of remarks. Primarily, the scope of its object demands closer specification. It has to be clarified to which type of commercial activity the provisions in question really relate. The definition of service, as included in the Act, relates with its wording to the notion of "service" specified in Article 57 of the Treaty on the Functioning of the European Union, according to which services are benefits, usually delivered against compensation, in the scope in which they are not covered by the provisions on the free movement of goods, capital and persons. Pursuant to Article 57 TFEU, services include, in particular: industrial activity, commercial activity as well as performance of freelance professions. However, according to Article 4(1) of the services directive, a service means any commercial activity run on one's own account, usually delivered against compensation, in line with Article 50 of the Treaty. Therefore, the Community regulations give a basis for rather broad understanding of the notion of service as commercial activity, in particular having industrial or trade nature, or related with performance of freelance professions. While formulating the definition of service, Polish legislator also provides only exemplary listing of types of commercial activities classified under that specific conceptual category. In effect, the catalogue in question is not closed, and its decoding in normative terms has to take into account numerous exemptions defined in Article 12 of the Act (relating to particular categories of commercial activities to which specific provisions of the Act do not apply).

13 The Act of 15 September 2000 - The Code of Commercial Companies (uniform text: Polish Journal of Law 2017, item 1577 with later amendments). 
A service provider from a member state may temporarily render services on the territory of the RP under the principles defined in the provisions of TFEU or in provisions of agreements regulating the freedom of services provision, without being obliged to obtain the entry into the business register in the National Court Register or in the Central Records and Information on the Commercial Activity. A service provider is understood as a foreign entrepreneur from a member state who involves in commercial activity according to legal provisions in force in his country of domicile, while temporarily offering or providing a service on the territory of the RP. Such temporary provision of a service may entail an obligation to obtain a license, a permit, an entry to the regulated activities register, a certificate or another form of rationing, unless provisions of separate acts impose such a duty with regard to public order, public security, security of state, public health or the environment protection. A service provider from a member state may render services on its own or jointly with other service providers from a member state and an exemption from that principle may be awarded if provided for under separate acts and is only admissible for the purpose defined under the act. A service provider is obliged to perform any reporting duties stipulated in the act.

Foreign persons other than an entrepreneur from a member state may render services on the territory of the RP in line with provisions specified in international agreements to which the Republic of Poland is a party or - where no such agreements exist - on the principle of reciprocity.

\section{Conclusion}

Normative reforms in the national legal order introduced in Poland by the Business Constitution in the area defining organizational and legal conditions for foreign investments on the territory of the RP should contribute, through their improved transparency and regulatory consistence, to alleviation of barriers hindering foreign capital's access to the Polish market. In this respect Polish legislator actually implements the Community directive on services and legal conditions provided thereby are intended to foster capital mobility and intensified economic cooperation with foreign business. The profound reform of Polish commercial law, carried out recently in order to improve legal and economic conditions for business and to facilitate relations between the business and the state, should also increase the attractiveness of Polish market for foreign investors. 


\section{References}

Begg, D., Vernasca, G., Fischer, S., Dornbusch, R. (2014). Makroekonomia. Warsaw: PWE. Budnikowski, A. (2017). Ekonomia międzynarodowa. Warsaw: PWE.

Burda, M. and Wyplosz, Ch. (2013). Makroekonomia. Podręcznik europejski. Warsaw: PWE. Directive 2006/123/EC of the European Parliament and of the Council of 12 December 2006 on services in the internal market (OJ L 376 of 27.12.2006).

Hejduk, I.K. and Bakalarczyk, S. (eds). (2013). Global Economics: Past, Present \& Future. Warsaw: Difin.

Kotyński, J. (ed.). (2005). Globalizacja and integracja europejska: szanse and zagrożenia dla polskiej gospodarki. Warsaw: PWE.

Mankiw, N.G. and Taylor, M. (2016). Makroekonomia. Warsaw: PWE.

Nowak, A.Z. (2015). in: A.Z. Nowak, T. Zalega (eds), Makroekonomia. Warsaw: PWE.

Nowak, A.Z. (2017). Globalizacja jako makroekonomiczny megatrend. in: A.Z. Nowak, K. Ryć (eds), Polityka $w$ regionach $w$ warunkach globalizacji. Warsaw: Wydawnictwo Naukowe Wydziału Zarządzania UW.

Nowak, A.Z. (2017). Kryzysy a finansyzacja gospodarki światowej. in: A.Z. Nowak, K. Ryć (eds), Polityka $w$ regionach $w$ warunkach globalizacji. Warsaw: Wydawnictwo Naukowe Wydziału Zarządzania UW.

Orłowska, R. and Żołądkiewicz, K. (2012). Globalizacja and regionalizacja $w$ gospodarce światowej. Warsaw: PWE.

The Act of 15 September 2000 - The Code of Commercial Companies (uniform text: Polish Journal of Law 2017, item 1577 with later amendments).

The Act of 2 July 2004 on the Freedom of Commercial Activity (uniform text: Polish Journal of Law 2017, item 2168 with later amendments).

The Act of 20 August 1997 on the National Court Register (uniform text: Polish Journal of Law 2018, item 986 with later amendments).

The Act of 24 March 1920 on Acquisition of Real Estates by Foreign Persons (uniform text: Polish Journal of Law 2017, item 2278).

The Act of 4 March 2010 on Provision of Services on the territory of the Republic of Poland (uniform text: Polish Journal of Law 2016, item 893 with later amendments).

The Act of 6 July 1982 setting the rules of running, on the territory of the People's Republic of Poland, commercial activity in the area of small manufacturing by foreign legal persons and individuals (uniform text: Polish Journal of Law z 1989 r., item 27 with later amendments)

The Act of 6 March 2018 - The Business Law (Polish Journal of Law 2018, item 646).

The Act of 6 March 2018 - Provisions implementing the Business Law as well as other acts regarding the commercial activity (Polish Journal of Law 2018, item 650).

The Act of 6 March 2018 on the Central Records and Information on the Commercial Activity and Information Point for Entrepreneurs (Polish Journal of Law 2018, item 647 with later amendments).

The Act of 6 March 2018 on the Spokesperson for Small and Medium-sized Entrepreneurs (Polish Journal of Law 2018, item 648).

The Act of 6 March 2018 on the principles of foreign entrepreneurs' and other foreign persons' participation in trade on the territory of the Republic of Poland (Polish Journal of Law 2018, item 649 with later amendments). 


\section{Can States Be Turned into Automotive Innovation Hubs?}

The article considers the hypothesis that in the face of the overlap of four trends that will shape the future of the automotive industry: autonomy, urbanization, digitization, and electrification, achieving success in the automotive industry in the coming years will require synergistic cooperation between the private and public sectors. In the context of global competition encompassing not only individual enterprises but also entire ecosystems, countries will have to rethink their ability to provide added value to their economies. On the example of electromobility, the article proposes five success factors for its development depending on the state situation. These are: the strength of traditional car companies, social expectations, job creation potential, internationalization possibilities, and the ability to incubate new entities. From the initial analysis, which requires further development and verification, it appears that countries such as China at the start seem to be in a privileged position to make the most of the potential of new mobility.

Keywords: Electromobility; Urbanization; Autonomization; Cybersecurity; Role of the State.

\section{Introduction}

The central goal of the New Structural Economics is to rethink the state as driving force for development. The liberal paradigm that has been functioning in the West since the mid-twentieth Century, part of which is world trade, gradually adopted by developing countries and then strengthened by the fall of communism, has led to increased standards of living on the whole planet. Taking into account GDP per capita, the statistical inhabitant of the planet has gained as much as four times between 1980 and the present moment, and the proportion of the poorest fell from $42 \%$ in 1993 to even less than $10 \%$ currently (Roser, 2018).

However, very serious global inequalities have turned out to be a side effect of the global market. Deepened by the financial crisis of 2007-2008 and the eurozone crisis since 2009, the growing gap between a handful of the richest and all the others has put into question the legitimacy of globalization. Enormous 
inequalities have become a source of contestation on the part of economists (Piketty, 2010). They also translated into the growing demand of voters for identity politics (Fukuyama, 2018).

As a result, the states are re-entering the arena. Although it would be more accurate to say they never really left it, especially the most effective and developing ones. But a recurring reflection on the need for industrial policy, long-unseen customs wars, and even more frequent use of sanctions policy, are a novelty in the world of developed countries. After years of consuming the fruits of growth through social policy, taking a recipe for growth from the Washington Consensus, strengthening regional ties and building global rules, all countries have been forced to rethink their role. In particular, how to become an added value for their economies.

The hypothesis adopted in this article is that states cannot do this effectively in abstract from the global trends that shape technology, business, society, and our surroundings. One of the most interesting fields of accumulation of these trends and the upcoming confrontation will be the automotive industry, in which four forces are going to play the pivotal role: autonomy, urbanization, digitization, and electrification. Neither a company nor the state can bring out the full potential of their interaction by themselves. Thanks to the fact that the synergic cooperation of the state and companies will remain an exception rather than a rule, the prize for its achievement will be global leadership and economic pension in one of the world's most lucrative branches of the economy.

\section{Autonomous Transport}

The beginning of the twenty-first Century is a period of unprecedented acceleration of innovation. Describing this situation, a number of authors expect the appearance of a "technological point of singularity" (Kurzweil, 2005), in which the machine's intelligence overtakes man's capabilities and, consequently, a gradual merger of man and machine (Harari, 2018).

For the automotive industry, however, this moment is not associated with a merger, and indeed with something exactly opposite. People will not have to drive their cars because the machine will be smart enough to do the job for them. Being the result of digital technology and the artificial intelligence and automation that arose from it, autonomous transport stimulates the imagination and mobilizes leading research teams and resources. Most large car manufacturers anticipate a breakthrough in the first half of 2020s and the 
appearance of the first fully autonomous vehicles on the roads. At first, they will be luxury vehicles or delivery vehicles moving on predictable and long routes - long-haul transport. Hardly anyone, however, doubts that in the perspective of 2030 autonomous vehicles in some form will also appear in cities.

Technological challenges are no longer an area reserved only for technology companies. Alliances are formed between traditional automotive players and new technological players, such as BMW and Intel, Fiat-Chrysler and Google (Waymo), or Renault-Nissan and Google. According to Morgan Stanley, between 2013 and 2016 the technology companies' purchases increased by tenfold by non-technological companies (Morgan Stanley, 2018). As buyers and hubs of digital innovation, companies such as Ford, GM, or Uber joined the traditional technology giants like Apple, Google, Facebook, and IBM. Among various areas of technology, artificial intelligence has become the fastest growing segment of growth. One of its main applications - recognition of the environment necessary for the widespread of autonomous cars, that is machine vision - has brought one-third of the M\&A transactions in this area in the last 24 months. The most spectacular was the purchase by the American Intel in 2017 of the Israeli start-up Mobileye producing a visualization system to assist the driver in driving. Recently, the takeover of the American start-up xPerceptions by Chinese technology giant Baidu was symptomatic. It proved that the race to an autonomous car ceased to be the exclusive domain of the traditional Western world (Hampleton, 2018).

It can be expected that in perspective of the next dozen or so years, the first fully autonomous vehicles will appear and gradually start gaining popularity in an increasingly complex communication environment - finally in cities as well. An autonomous revolution will relieve people from driving, giving them more time for other activities. But at the same time, it will encourage longer journeys, and thus further increase the distance between home and workplace. Provided that the development of infrastructure with the new vehicle capabilities is kept up, this will translate into further, spectacular development of cities.

\section{Urbanization}

While at the beginning of the nineteenth Century only one in 50 world residents lived in the city, nowadays, up to half of the world's population inhabit urban areas. The largest cities in the world have experienced spectacular growth over the last couple of decades. In 1990 there were 10 megacities counting over 
10 million inhabitants each. By now their number increased to almost 30 and they are inhabited by little less than 500 million people. In perspective of 2050, two out of three people will live in cities around the world. This means between 6 and 7 billion people out of 9 billion living on the entire planet (...).

Urbanization entails a number of consequences, the scale and intensity of which we cannot quite imagine. One of the most important will be the answer to the mobility needs: from cities "into the world" - as tourists; between the place of work and place of residence - as employees; between cities - on business. There will be a growing need for individualization of moving, although not necessarily ownership of transportation means. Convenience measured by access and ease of use, rather than the social aspiration measured by possession, will be the new norm. Already today, New York has much lower saturation with cars than Warsaw. The car as a tool for self-realization will lose its importance to the benefit of a vehicle allowing for smooth transition from place A to place B. The success of Uber or Lyft is already a foretaste. Car companies are more and more aware of this, and the global alliances built by city carriers and vehicle manufacturers are meaningful in this context: GM and Lyft, Volvo and Uber.

Vehicle banalization is inevitable if we realize the scale of the upcoming challenge. The supply of means of transport, especially cars, is very uneven between different parts of the world. There are between 300 and 600 cars in Europe per 1000 inhabitants. In the United States, this is almost a one-to-one ratio. In India, this ratio still amounts to only 50 cars per 1000 inhabitants. At the same time, it must be remembered that India is a rapidly growing country, a country of young people: in 2030, $60 \%$ of Indians will be under thirty; in 2050, 700 million people will live there in cities. Can we imagine even more cars moving on the roads of this country? Judging by the crowded streets of New Delhi, Calcutta, Mumbai and other major cities, it seems next to impossible. Satisfying the needs and aspirations of city dwellers, e.g. in India or China, in the field of mobility will become one of the greatest challenges of the $21^{\text {st }}$ Century.

In the context of urbanization, it is not clear whether the proliferation of autonomous vehicles will contribute to the discharge of communication problems or, on the contrary, will lead to their deepening. On the one hand, through sharing, an autonomous vehicle will free today's unused vehicle time, while also freeing parking spaces. On the other hand - man will be able to manage his time in a different way, allocating it to entertainment, work and rest. The convenience of not owning a means of transport combined with cheapness of using it may cause displacement of public transport, which is already partially observed in cities, where it has become popular, e.g. Uber. 
As a result, there is a risk that the city will spread even more in space and its center will become even more congested. Initial research based on experiments with autonomous transport in Boston seems to confirm this thesis (BCG, 2018). As a result of the hypothetical popularization of autonomous transport, the total travel time will be shorter. However, in the city center it will become longer ("congestion effect"), while in suburbs it will significantly shorten commuting (consequently provoking the "stretch effect"). However, these tests are conducted with ceteris paribus, without changing other parameters, such as public transport policy, taxation and restriction of entry to city centers, availability of parking spaces. Then, as revealed by the example of Tokyo, it is possible to radically relieve the city center of car traffic, thanks to very good access to public transport. On similar premises the authorities of Singapore rely, as they assume that by $2030,80 \%$ of the city's residents will have a subway or bus station within a 5-minute walk from where they live. The best-configured city systems will discourage individual vehicles.

In any case, the interaction between urbanization and autonomy will be a challenge. Through autonomy, the cost of individual transport will be reduced, which will inevitably translate into increased demand for such services. As a result, the role of the brake will be taken by the city authorities and regulators. By restricting traffic, supporting public transport, expanding the infrastructure will be limited by individual vehicles in the centers. Their ally will be the digital integration of vehicles and infrastructure.

\section{Vehicles Digitally Integrated}

One of the most obvious megatrends of recent years, which is already talked about a lot, is the increasing significance of communication and data exchange between devices. In particular, vehicles integrate digitally with other vehicles and infrastructure. In 2020, all new vehicles will be connected in the network (BCG, 2018). It is an opportunity to increase traffic safety, reduce failure. Autonomous vehicles connected in the network will limit the role of the weakest link in driving a vehicle, which is a human being. They will be less vulnerable to accidents. Communication with service facilities will allow faster and better response to failures and technical problems. But not only that.

Digital and communication integrated vehicles will open new perspectives for insurers, advertisers, and various service providers. Relieved from the attention needed to drive a vehicle today, the passenger will become an attractive object 
of advertising activities. The ability to deliver products to moving vehicles will enable the integration of drones and vehicles. New business models and new industries will appear around mobility.

Gradual digitization of all areas of human activity opens up enormous potential. In the context of autonomous vehicles and combined infrastructure, it also challenges the security of data. The future incidents will probably be less numerous, but the ones that will take place may be more spectacular if they are caused by terrorist activity or system failure. Cyber security will become one of the most crucial areas of the economy. The need to provide it will also motivate the growing intervention of states. It will not be possible to maintain the overall system continuity without centralized monitoring. While the creation of security standards will be the private sector's work, their popularization will be the role of the regulator.

Digitization will go hand in hand with the growing importance of electricity. While it is said that the $20^{\text {th }}$ Century was under the sign of crude oil, more and more points to the fact that the $21^{\text {st }}$ will be the Century of electrification. Electricity as a drive for the development of civilization is also a new perspective for the road transport sector.

\section{Electrification as a Response to Environmental Pollution and Climate Challenges}

The rapid economic development of the end of the $20^{\text {th }}$ Century is also a growing climate and environmental challenge. From perspective of the commitments undertaken by the States under the Paris Agreement, it has become necessary to reduce carbon dioxide emissions in transport. It has become the fastest growing source of emissions in OECD countries (IEA, 2018). In the rapidly developing countries of the South, cities have become the area of smog and the main source of noise. Across the world, air quality is deteriorating at an unprecedented rate due to growing vehicle traffic. It involves the emission of soot particles and nitrogen oxides. Over three million premature deaths in the world are associated with air pollution with $2.5 \mathrm{PM}$ soot particles. One in four of these molecules comes from transport (CCAC, 2018).

Electric cars are the answer to the growing demand for cleaner and quieter cities. Replacing a combustion engine driven car with an electric car reduces emissions of nitrogen oxides by up to $80 \%$. Electric cars allow to alleviate the smog in cities. They also allow to reduce carbon dioxide emissions by between 
$25 \%$ and even $60 \%$, depending on the method of electricity production. The popularization of electric cars in cities will reduce noise levels on the streets. In addition, an electric car can be very convenient. As research shows in markets where they have become widespread - e.g. in Norway or in California - drivers are happy to charge their car at home without having to stop at service stations (IEA, 2018) In many countries, charging at night also lowers the costs of using the car. There is no manual transmission, which is especially convenient when driving in the city.

Until recently, until the first years of the $21^{\text {st }}$ Century, electric vehicles had no chance of becoming widespread. The prohibitive cost of batteries, the lack of charging infrastructure, the reluctance of traditional car manufacturers to cannibalize their know-how, the lack of a secondary market have acted as serious barriers in this respect. However, several factors indicate that they will soon become cost-competitive compared to traditional combustion-engined vehicles. Among the alternative fuels, electromobility will the soonest become popular. It will leave hydrogen vehicles behind, as well as ones fueled by biofuels and natural gas, although of course it cannot be ruled out that the next innovations will break this trend with time as well.

This will happen because the cost of owning a car is not only the cost of purchase, but also that of fuel, maintenance and repairs. Driving around in electric cars has already become cheaper and more convenient than with combustion cars. Maintenance and service costs are lower, because electric cars are less complex (their motor and transmission have about 1000 parts less), they do not need oil change or filters. However, the key to their popularization will be the falling cost of lithium-ion batteries, which will translate into a lower price for buying an electric car. The batteries, constituting $40 \%$ of its production costs, are cheaper by 10-15\% annually (IEA, 2018). As a result, it is estimated that in the 2020-2022 perspective, the total cost of owning an electric car - calculated in its entirety, including costs of purchase and use over a period of at least five years - will become lower than that of combustion engine driven cars. The market will grow faster and faster, going from linear to exponential growth. This is already visible: it took 60 months to sell the first million electric cars, the second million took only 17 months, the third one was already down to 10 months, and the fourth million was achieved in August 2018 in 6 months. In the global perspective, it is estimated that from the current $1 \%$ of vehicles, the "electrics" will achieve between 20 and $40 \%$ market share. In Europe alone in 2030, it will be 5 million new electric cars per year. In the 2040 perspective, between 250 and 500 million vehicles will be powered by electricity among 2 billion around the world. 


\section{The Development of the Automotive Industry and the Role of the State}

Means of transport, especially the individual car, will therefore undergo intense (r)evolution over the next decades. Increasing urbanization combined with digitization and autonomy will force new business and regulatory models. The car will be driven from the realm of ownership to the sphere of use. Technological progress will allow the evolution of the drive from internal combustion engine to electric motor.

We will use the vehicles of the future in other ways than ever before, evolving from ownership to sharing. It is estimated that in 2025 there will be 80 million car-sharing users in the world. In perspective of 2030, one third of travel in India will be made using shared means of transport, which will put this country in the leading role of this type of communication. Sharing will take root as an alternative to the development of public transport, which among developing countries does not have the popularity it is due, requiring long-term spatial planning and funds for investments.

Electric vehicles of the future, charged at night, will move in an automated manner on predefined routes. Diversified delivery vehicles will spread from heavy trucks through semi-heavy trucks to last mile transport, possibly including drones. While the first cars looked like cabs, the vehicle of the future does not have to resemble its late $19^{\text {th }}$ Century grandfather or father from the $20^{\text {th }}$ Century. Between the family vehicle and the bus, there will be space for small, autonomous vehicles transporting for short distances: between the place of residence and the subway; within the district. This is an opportunity for new companies that will focus only on electric cars. In particular, the creation of a low-budget electric car will radically change the market image.

Electric cars will reduce the dependence on oil. Many states will find this argument attractive enough to support the widespread use of electric vehicles.

The state will play a key role in accessing the new value potential. There will be no autonomous transport without sophisticated legal regulations, defining parties' responsibility and security standards. Sharing transport will significantly benefit from privileges, including fiscal ones. Electrification will not be possible without proper determination of legislators and initial co-financing from public funds. Digital mobility will be conditioned by access to sophisticated cybersecurity competences that only the community at the state level will be able to collect as a public good. There will be no new, high-paying jobs without advanced education systems. 
New business models will open, the old ones will be ruined, giving new players the chance or strengthening the advantage of the existing ones. New mobility, digital, autonomous, electric, and shared is the prospect for the automotive industry to grow. USD 2,500 billion in new revenue over the next 20 years is estimated. At the same time, the existing technologies will practically not budge. The entire $40 \%$ sector growth will be attributed to new mobility, opening the "blue ocean" (...) for pioneers. In a traditional car business, the lack of growth dynamics will mean regression (BCG, 2018). More simple competition, inevitably costly, a continuation rather than a breakthrough will cement the "red ocean" as a competitive space for the traditional car industry.

The best pioneers will collect priority pension. Countries that synergistically transform their industry towards new mobility will gain a chance for global leadership. Companies that benefit from the imagination of their managers and legislators will take advantage of the potential of domestic markets and assets to build global advantage. New mobility re-evaluates the current competitive landscape. Although traditional car manufacturers will remain well positioned to capture the potential of the new value, they certainly should not take it for granted. The electrification of the vehicle will put everyone on the new starting grid. New business models will open up new spaces of competition. New producers, such as Tesla, NIO, Faraday Future and Lucid among others, have a unique chance in this new race for an equal start together with BMW, Renault and Ford. It may also turn out that electro-mobile innovators - thanks to the unique chance of the lack of accumulated luggage of the traditional manufacturers' legacy - will gain an advantage in the new global deal, even at the start. After all, the Tesla valuation that surpasses the capitalization of GM really proves something.

\section{Opportunities for New Producers}

The combination of business, social, and technological change is a unique moment for new producers. The domination of the internal combustion engine has established a specific market structure prevailing throughout the $20^{\text {th }}$ Century. However, classical producers have no interest in the rapid electrification of transport. On the one hand, they need time to recoup their investments in combustion cars. Then, we have to remember they will lose up to $50 \%$ of the margin currently generated by the service. It is through selling and fitting spare parts that they get their profitability throughout the entire life 
cycle of the vehicle. Considering that an electric vehicle is significantly simpler, they will not be able to use their production assets or suppliers.

It is estimated that for the Volkswagen group alone, the loss of jobs caused by electrification of vehicles amounts to reduction of employment by at least $10 \%$, or 60,000 employees. By defending themselves, classical producers apply all available, even illegal, methods to limit the pace of this transformation, which can be seen by the collusion proceedings launched in September 2018 by the European Commission to limit the popularization of clean transport by European producers. They conduct electrification in a selective manner, focusing on non-mass segments. To a lesser extent they are trying to dominate new areas, but all in all they are mostly fighting to maintain their existing ones.

An additional challenge is the baggage of inefficiency that they, historically, carry behind them. Their extensive dealer networks are ineffective and costly in the internet age, as illustrated by the direct selling method used by Tesla. The employment structure in factories is not adapted to electric cars due not only to scale, but also to competences. Skills in the field of energy chemistry, electrical engineering, computer science necessary for the production of battery "computers on wheels" replace the classical skills in the field of "hot" mechanics.

New mobility will allow the creation of high-paying jobs. Each new factory of electric cars or complex components means hundreds, and often thousands, new jobs. Every workplace at the car manufacturer allows creating additional 3-5 jobs outside the factory, e.g. from sub-suppliers. Not only high salaries, but also competences in the field of automation, artificial intelligence or cyber security will bring additional benefits in other areas: smart city, energy, security, IT banking, insurance. New mobility companies will contribute to the promotion of their country's image.

Launching profitable production at the level of several hundred thousand copies is an investment of several to several billion dollars, which, however risky, may already be attractive for the investors, and certainly for the countries and regions that will bet on them. A telling example of this is the creation of Tesla supported by public funds, but also the tremendous capitalization, which is now followed by subsequent ones.

\section{Electrification of Transport and Strategies of Selected Countries}

However, not all countries and not every economic ecosystem will be able to benefit from the described (r)evolution. Most countries will become stuck in 
inefficiencies characterized by bureaucracy or in the sluggishness of the political system. There are few places in the world where it is possible to accumulate sufficient capital to incubate new, risky businesses. In many mature markets, the technological change will encounter the resistance of the contemporary "Luddites", for whom it will carry the loss of previous occupation. Even if new entities germinate locally, and the regulatory system proves efficient enough to support them, in the economically fragmented world which beacons on the horizon it is not sure at all whether they will be able to lead them to global markets, giving the chance to spread their wings. Obstacles will abound and hinder or stop the launch of synergic cooperation between the state and companies in its area of influence.

The inclusion of all possible interdependencies between these four trends and strategies of states is a calling that goes beyond a single article. However, to build a certain set of hypotheses - success factors of synergic cooperation - the described fourfold revolution has been reduced only to the technological change, i.e. the transition from a combustion vehicle to an electric motor.

To achieve the full development potential resulting from electrification of vehicle drives, it is assumed that effective interaction between the public and private sectors will be based upon a combination of at least five factors: the strength of traditional car companies, responses to social expectations, potential for new jobs, internationalization opportunities, and the ability to incubate new players. Each of them is outlined below on the example of seven countries: Germany, China, USA, France, Great Britain, Norway, and Poland. The choice of countries is arbitrary, and the description of the situation in each of them does not aspire to be seen as exhaustive, but only serves to set some hypotheses that will be the basis for further research.

The biggest challenge on the road to using the potential of electric mobility is the strength of traditional car companies. Because effective technological change requires smooth and synergic cooperation between the state and the private sector, countries in which the traditional automotive industry operates will be subject to tendencies to slow it down. In particular, the strong surplus of EUR 150 billion in export in the automotive industry, achieved due to accumulated know-how in the field of internal combustion engine, Germany will treat electrification of transport in more defensive rather than offensive categories. On the other hand, China will see an opportunity to "jump over, not catching up", i.e. to create its own industry in a new technological niche in opposition to today's tycoons. Countries like Poland, Norway, or the United Kingdom - deprived of domestic producers - will be able to incubate new entities in the technological change. The positions of the US and France, positioning 
themselves on the opposite poles in terms of climate ambitions, will to some extent be the tributaries of these elections.

The development of electromobility will proceed best where it will respond to social expectations. Countries where societies struggle with air pollution, such as China or Poland, will not have difficulty in convincing their societies to the benefits of clean transport. Also, the population density of megacity, such as Paris, will help build support for it. Environmental and climate awareness will contribute to it becoming widespread, at least in some US states (e.g. California), in Germany, and Norway. An obstacle will be the financial possibilities of societies, toning the development of expensive electric vehicles in poorer societies such as China and Poland, and promoting them in the rich ones, such as Norway or California.

The potential for creating new jobs will be greatest in dynamically developing countries, especially in industrial terms, in countries such as Poland and China. For Germany and France, the employment balance will initially be negative, causing resistance from trade unions confronted with the loss of traditional jobs. Norway or Great Britain will face a difficult situation, the former due to the small scale of the car industry, the latter due to Brexit, which entails considerable uncertainty for companies operating on the islands. However, this last argument can also strengthen the government's determination to seek all possible ways to create new employment. Given the importance and diversity of the American market, the global technological revolution will support jobs there, even if the balance across individual states will be diametrically different.

For all the countries discussed, the possibilities of internationalization, understood as an ability to establish productive international cooperation, as well as building the image of a country that positively resonates with electrification of transport, are very important. Pioneers such as Norway and the largest market - China - will benefit the most. Inconsistency in climate policy between the federal government and certain states, in particular California, will make the possibility of using electromobility for promoting the United States rather ambiguous.

There is still the ability to incubate new players, which is one of the most difficult conditions to meet, and at the same time a prerequisite for success. In the best situation are mature economies with strong competences, advanced cooperative ties, and having high-risk capital resources, in particular the US. The countries that have adopted radically different models of development, such as China, having a strong tradition of state control and, at the same time, tools for its expression in the sphere of the economy, have an advantage here. In the most difficult situation are the countries of the European Union 
bound by common rules of competition protection. France, confronted with the challenges of deindustrialization for years, has no tools for incubating industrial entities. The German economy is also relatively traditional, although it manages to build new entities, also in the field of electromobility, even for the needs of German mail. Being at the middle stage of Brexit, the United Kingdom will not have the full capacity to use all the opportunities that its economic potential and access to financing offers. Positions of Poland and Norway are also weak.

The above considerations have been included in tabular form, where they were assigned grades from the least favorable (-), through neutral (0) to good $(+)$ and very good $(++)$.

Table 1. Schematic evaluation of the prospects for the development of electromobility for selected countries

\begin{tabular}{|l|c|c|c|c|c|c|}
\hline & $\begin{array}{c}\text { Lack of natural } \\
\text { opponents } \\
\text { hampering } \\
\text { the development } \\
\text { of electromobility }\end{array}$ & $\begin{array}{c}\text { A response } \\
\text { to challenges } \\
\text { and social } \\
\text { opportunities }\end{array}$ & $\begin{array}{c}\text { The } \\
\text { possibility } \\
\text { of creating } \\
\text { new jobs }\end{array}$ & $\begin{array}{c}\text { Potential } \\
\text { in the } \\
\text { international } \\
\text { sphere }\end{array}$ & $\begin{array}{c}\text { The ability } \\
\text { to incubate } \\
\text { new players }\end{array}$ & Total \\
\hline Poland & + & + & ++ & + & - & 4 \\
\hline China & ++ & + & ++ & ++ & ++ & 8 \\
\hline Norway & + & ++ & 0 & ++ & - & 4 \\
\hline Germany & - & + & - & + & + & 1 \\
\hline USA & 0 & + & + & 0 & ++ & 4 \\
\hline France & 0 & + & - & + & 0 & 1 \\
\hline $\begin{array}{l}\text { Great } \\
\text { Britain }\end{array}$ & + & + & 0 & + & - & 2 \\
\hline
\end{tabular}

The scale from the worst to the best rating: $-, 0,+,++$

Source: own study.

As a result, a hierarchy of countries emerges that have the best conditions for the popularization of electromobility. China seems best positioned to take advantage of the electromobility revolution. The size of its market, the ability to support pioneers, benefits of the global technological revolution predestine this country to take on global leadership in the field of electrification of transport. The facts that every second electric vehicle in the world is sold in China, that the largest lithium-ion cell factories are built there and that enterprises such as BYD, albeit from a great geographical distance, dominate the world market of electric buses, confirm this diagnosis. USA, Norway and Poland figure high in the ranking, for various reasons: USA as a global technology leader and the most innovative economy in the world. Norway, for its considerable wealth 
and expectations of its residents. Poland - because it successfully aspires to the group of the $21^{\text {st }}$ Century industrial tigers. The Great Britain ranks in the middle, while Germany and France seem to face the least favorable situation, where electromobility means confrontation with traditional industry in the context of a very uncertain fight to maintain global supremacy.

\section{Conclusion}

It should be emphasized that the above comparison is illustrative and schematic. It requires empirical verification. Its value is in the fact that it indicates factors that may affect the success of a given country and its companies, called synergic cooperation. On the example of electromobility alone, it shows various motivations and various barriers that may be experienced by countries on their way to reaching the potential value that are going to emerge from the overlap of the four trends that will shape the car industry of modernity: autonomy, urbanization, digitization, and electrification.

There are many indications that it is the synergistic cooperation between the state and the private sector that will be a prerequisite for taking advantage of the opportunities that are emerging in the field of new mobility. In most countries of the world these opportunities will remain undeveloped, but wherever you can reach for them, the prize will be a competitive industry, high-paying jobs and a global rent resulting from technological advantage.

\section{References}

BCG. (2018). Analiza rynku elektromobilności i jego potencjału. Warszawa: The Boston Consulting Group.

CCAC. (2018). Briefing Paper by Climate and Clean Air Coalition for G7 Environment Ministers' Meeting on Urgent Action and Reduction Opportunities. Halifax, Canada: Climate and Clean Air Coalition.

Fukuyama, F. (2018). Against identity politics. Acquired from: https://www.foreignaffairs.com/ articles/americas/2018-08-14/against-identity-politics.

Hampleton Partners. (2018). Artificial Intelligence AI market report. Acquired from: https:// hampletonpartners.com/mediaarticle/hampleton-partners-artificial-intelligence-ai-marketreport/.

Harrari, Y. (2018). Homo Deus. Warszawa: Wydawnictwo Literackie.

IEA. (2018). Global EV Outlook. Paris: International Energy Agency. 
Kurzweil, R. (2013). Nadchodzi osobliwość. Warszawa: Kurhaus Publishing.

Morgan Stanley. (2018). 5 acquisition trends investors should watch in 2018. Acquired from: https://www.morganstanley.com/ideas/5-acquisition-trends-investors-should-watchin-2018.

Piketty, Th. (2013). Le Capital au XXIe siècle. Paris: Edition de Seuil.

Roser, M. (2018). The short history of global living conditions and why it matters that we know it. Acquired from: www.ourworldindata.org.

UNGC (2016). Zrównoważone miasta. Życie w zdrowej atmosferze. Warszawa: United Nations Global Compact. Acquired from: http://ungc.org.pl/programy/zrownowazone-miasta/Miasta zrównoważone. 


\section{Poland on the Route of the Chinese Silk Road: A Chance for Development or Just a Challenge?}

The two Chinese Silk Roads going to Europe, announced in autumn 2013, surprised not only European and global political elites, but academic circles as well. This unprecedented project or vision of Chinese President Xi Jinping draws attention with its spectacular scale and range. It is the proof of China's rebirth as a power and of its global ambitions. The aim of this study is to show how the project is referred to by the elite of the European Union countries, the region of Central and Eastern Europe, involved in the other Chinese strategy, 16+1, and by Poland, which found itself directly on the land route. What did Poland do with this opportunity? The analysis shows that relatively little - despite the noticeable Chinese presence and interests located here. Therefore, the Silk Roads remain a rather untapped potential opportunity for Warsaw than a real new development opportunity. To change this, a political will is required which seems to be lacking on the Polish side.

Keywords: Belt and Road Initiative - BRI; Strategy 16+1; China; Europe; Geopolitics; Development Strategies; New Economic Order

\section{Introduction}

Announced in autumn 2013 in two rounds by President Xi Jinping, the project, or rather a geostrategic vision, in the original called Yidai, yilu, first introduced to the international audience as One Belt, One Road (OBOR), and then BRI (Belt and Road Initiative), at the time of its appearance aroused consternation even in China itself, not to mention the outside world. It was announced by the country that so far has been keeping in line with taoguang, yanghui formula dictated by the visionary reformer Deng Xiaoping in the early 90 s of the last century, that is building the power quietly, without attracting anyone's attention, trying 'to conceal its capabilities and avoid the limelight'. Afterwards it came up with an unprecedented project, the implementation of which can bring about a significant change of the balance of power in the world. 
In China, this idea was quickly translated into concrete actions: in all the major academic centers of the country special teams, faculties, and even research institutes were established to constitute the scientific background of the BRI, with the basic task to fill this concept with substantive content. As initially, at the very beginning of that road, there were only five proposals of the President of China for countries that would like to join the project: policy coordination, better communication (road and rail), open trade, financial exchange, and closer cooperation between the citizens. ${ }^{1}$

Very soon, the Chinese scientific community and experts revealed that this is about something more - in essence, about showing China as a new geostrategic player, benefiting from its rapidly growing economic and financial potential, returning to the status of a superpower and a great center of strength and ideas that China has held for centuries before (Maddison, 2007). And some have even admitted that when creating this concept, China reached out to the ideas of "geostrategic fathers", that is Halford John Mackinder and Nicholas Spykman, talking about the Heartland connecting Europe and Asia and the surrounding chain of the seas and oceans, i.e. Rimland (Zhang, 2016, p. 28; Bartosiak, 2016, p. 70, 71). The distinctive feature of this concept is that those Silk Roads, both land and maritime, are heading towards the West, first of all to Europe (though with branches to the Middle East and even to Africa, and with time it turned out that some of the projects within them were initiated even in Thailand or Indonesia).

The concept of OBOR, and later BRI (the Chinese name remained the same) in the outside world, and above all in the broadly understood West, was met not only with surprise, but also with mixed feelings. Yes, there have been opinions that the BRI is "the most significant and far-reaching initiative that China has ever presented" (Winter, 2016). However, much more often the thesis was made saying that a new heaviest weight player entered the world stage, which naturally aroused the greatest consternation in the USA, the current hegemonic power on the world stage.

A bulky proof of this thesis is the book of Michael Pillsbury who spent his whole life in the American intelligence-analytical community dealing with China. After the publication of the OBOR concept, he published a volume with the significant title of "The Hundred-Year Marathon", in which he referred to yet another strategic concept of Xi Jinping, concerning "the two centennial goals". The first goal, for the centenary of the ruling Communist Party of China (CPC), to be implemented in mid-2021, is the change of the local economic model and basing it not on exports, as it used to be, but on a strong and thriving

Land Silk Road announced on September 7, 2013 in Astana and the maritime Silk Road announced on October 3, 2013 in Bali, Indonesia (see Xi, 2014, p. 315, 320). 
middle class and dynamic domestic market. The second "centennial goal", for a round hundredth anniversary of the proclamation of the People's Republic of China (PRC), and thus to be completed on October 1, 2049, is nothing else, then the "great renaissance of the Chinese nation", which requires meeting a number of serious requirements, including the most crucial one - a peaceful unification with Taiwan, because until now we are, after all, dealing with two organisms with China in the name (On the new development model: Góralczyk, 2017b, p. 41-55.On the new geopolitical strategy: Góralczyk, 2018).

According to Pillsbury and many other experts, these "two centennial goals", combined with the BRI, just confirm the emergence of a new geostrategic player, and also the most powerful US rival to the leading role on the globe, to what the United States have contributed for decades, from Henry Kissinger's and President Richard Nixon's visits to the PRC in the early 1970s. According to Pillsbury, that American attitude has appeared to be "perhaps the most systematic, significant and dangerous failure of intelligence in American history" (Pillsbury, 2016, p. 16).

\section{Perception of the BRI}

\subsection{In the European Union (UE)}

The problem is that the Chinese Silk Roads quite unequivocally show a new pretender to hegemony on the world stage, which must raise the understandable consternation of the current hegemon, the USA. Thus, the situation was called by the experts of Harvard University "the Thucydides Trap", when the interests of the current leading power collide with the interests of the pretender, which usually leads to a war, and frequently not only a commercial one. That is what we are observing already now, especially in the South China Sea, controlled so far by the American fleet, but on the shores of which, in the port of Xiamen and a few other places, the Maritime Silk Road has its beginning, which forces the Chinese to increase their presence, also military, in this reservoir. This is an area where the "Thucydides's Trap" is openly set, and the territory of direct clash of influence and interests of the US and the PRC. Thus, both here and across the international arena a confrontation of the two giants seems to be inevitable. ${ }^{2}$

2 The idea comes from a retired and experienced researcher and administrator from Harvard, Graham Allison, who - together with his team - has examined the period from 1500 to the present in this category. It turned out that there were 16 'traps' in that time, 12 of which ended in war. Cf. (See Allison, 2017; or Bartosiak, 2016, p. 554-663). 
The beginning of a real commercial war, initiated in the spring of 2018 by the administration of President Donald Trump, who promotes the slogan America First and in fact isolationism in trade ${ }^{3}$, widespread to a larger extent in September, encounters Chinese retaliation and collides with the free trade policy promoted by the Chinese authorities, without obstacles and inhibitions ${ }^{4}$. Simultaneously we have a paradox situation: while the US is voting for narrow national interests, China is still strongly supporting globalization and open markets, as Xi Jinping so strongly emphasized in his two high-profile speeches at the Davos Economic Forum in January 2017 and at a similar Forum in Boao in April 2018 (Xinhua, 2017; Xi, 2018).

OBOR, and then BRI, were met with mixed feelings also in the EU and its institutions. The approach towards the BRI of the Member States in the EU was also highly diversified. In the analyzes available today (two best and most inquisitive are: Godemont and Vasselier, 2017; MERICS and Rhodium Group, 2017), there are indeed indications of new opportunities and possibilities, following the Chinese concepts and their new presence in Europe. However, so far they are rather unknown, neither as to scale, nor - capital and investment - commitment. Even more often, the other arguments are emphasized, and over time growing and gaining more power. According to them: the Chinese vision has serious shortcomings and faults, such as lack of precision in rearranged maps and BRI routes, forcing the interests of its own companies, is lacking of transparency of proposed contracts, is incompatible with the proposed agreements with EU standards and norms, has many ambiguities regarding financing and public tenders for individual projects, and issues of respecting property rights, as well as paying too much emphasis on bilateral agreements with individual EU Member States that almost without exception suffer from a chronic trade deficit from the PRC, sometimes exceptionally high, which leads, on the one hand, to the "asymmetry of impact and influence", while the other threatens to implement China's "divide and rule" strategies among member states. These opinions and allegations even found a diplomatic reflection when, in April 2018, EU ambassadors in Beijing, with the exception of a Hungarian representative, formulated these claims in writing, starting with the most serious charge - that the implementation of the BRI threatens the breakdown of the EU.5

3 Initial analyses: https://www.project-syndicate.org/bigpicture/trump-s-trade-war-expands (16.07. 2018).

4 https:/info.expeditors.com/newsflash/president-trump-announces-200-billion-in-section-301tariffs-on-china My comment: https://www.obserwatorfinansowy.pl/forma/rotator/chiny-usawojna-handlowa-czy-zimna/

5 https:/global.handelsblatt.com/politics/eu-ambassadors-beijing-china-silk-road-912258 (access: 20.07.2018). 
The basic shortcoming of the EU in its relations with China - and in general with 'emerging markets' - is the lack of a coherent and uniform strategy towards them, what all the more leads to asymmetry in the light of bold visions within the BRI. Unfortunately, that kind of conclusion comes to our minds, even despite the adoption by the European Commission in November 2013 of the strategic agenda for cooperation in bilateral relations with China for the period up to 2020 and placing there as many as 94 "key initiatives" (EEAS, 2016) regarding this cooperation in not only the economic or trade sphere, but also for example in the field of security and peace, in the field of sustainable development, scientific and scientific cooperation, tourism and personal exchanges.

The second factor, which emerged very soon after the announcement of the Chinese Initiative, is the rapidly growing Chinese investment presence in the EU, which in 2016 reached EUR 35 billion (increase by as much as 77 percent in relation to the previous year), while the EU's presence in the PRC territory reached only EUR 7.6 billion. ${ }^{6}$ For - what should be stressed and emphasized - just one year after the announcement of OBOR's vision, Chinese investments abroad exceeded those coming to China, which have always been high since at least 1992, that is the year of the opening of China to globalization immediately after the collapse of the USSR. This change must be regarded as a Copernican turn in the Chinese development strategy, and stand, to a large extent, behind President's Xi Jinping vision of the BRI. After two decades of global opening China has started to have capital surpluses and investment powers which are and will be properly used not only at home but also on foreign markets.

And finally, the third, crucial element: as it soon turned out, the Chinese side comes to Europe and the EU with new investments, but not in a greenefield form, that is the ideas of building new objects from the foundations, but rather it is interested in merger and acquisition operations, especially acquisitions of companies or brands specializing in modern and newest technologies. It was the acquisition of the Swiss chemical company Syngenta for an estimated sum of 65 billion dollars, and then a German company Kuka, specializing in the production of industrial robots (for an estimated amount of 5.5 billion) that made all European countries, including Germany, the most involved in cooperation with China, to finally realize that they were dealing with a completely new Chinese presence on domestic markets, where the 'crown jewels' are taken over, as it was perceived in media. As a result, even the then foreign minister of Germany, Sigmar Gabriel, began to encourage close cooperation between EU member states and the development of a common strategy for dealing with

6 And all this with a negative trade balance of the EU in the same year of 174 billion euros (see Godemont andVasselier, 2017, p. 37). 
China, because - as he said - "if we fail to work out a common strategy towards China, then China will succeed in dividing Europe" (Godemont and Vasselier, 2017, p. 17).

It was only the takeovers of modern companies and the high investment presence of China on the European continent that, to some extent, "woke up" the EU institutions and the authorities of individual Member States. Finally, they realized that the idea of the BRI is actually being implemented and cannot be in any way ignored, as it was at the very beginning just after its announcement. Its implementation creates a completely new quality in the EU's mutual relations with the PRC, requiring from the EU countries a new consideration, reflection and a real strategy in these completely new circumstances.

At the same time, however, quite understandably, the EU authorities are cautious in accepting Chinese suggestions to "join forces" in a win-win strategy, proposed by Beijing, in order to counter US Donald Trump's initiatives to limit trade and isolate its market. The EU also loses on these American ideas, but quite clearly underlines that the US remains its key strategic partner. In other words, even the threat of a trade war does not mean a change in alliances or a new configuration on the global scene. ${ }^{7}$ In other words, the EU does not bet on China. And what about the CEE region countries?

\subsection{In the Region of Central and Eastern Europe (CEE)}

The specificity of the relations of the CEE region with China is that these countries have also started, on China's initiative, enhanced cooperation with the PRC even before the announcement of the BRI. The previous Prime Minister Wen Jiabao announced in Warsaw in April 2012 the concept of cooperation within the $16+1$ formula invented in Beijing, that is China with 16 countries of the region (four from the Visegrad Group, three Baltic States and the Balkan states, with Romania, Bulgaria and Albania as well as post-Yugoslavian states, without Kosovo). Such and no other composition of the 16 proves that China does not pay too much attention to the EU borders (11 members, 5 candidates), and - even more so - the euro area. More convincing was for them the geographical proximity of these countries in the previously poorly recognized and less important region at the gates of a strong Western Europe. A region somewhat diverse but seen mainly from one vantage point: it formerly shared experience of "real socialism" or planned economy.

"We don’t agree with Trump, but that doesn't mean we want to gang up on America with China, says EU adviser ahead of summit"; seehttps://www.project-syndicate.org/bigpicture/ trump-s-trade-war-expands (16.07.2018). 
Originally, the Chinese side, in the framework of this cooperation, proposed a vision of " 12 projects" or steps and allocated for these purposes a sum of 10 billion dollars. Few of these plans were successfully implemented, and the symbolic "flagship" of this cooperation, that is, a fast Chinese railway connecting Budapest with Belgrade (ultimately it would be about connecting the port of Piraeus, in the hands of the Chinese company Cosco and being an end, thus far, of the Maritime Silk Road, with Łódź, which is an important center in the Chinese transport plans on the route of the land Silk Road). This idea is still not being implemented today, because of resistance - and accusations - of the European Commission due to a "lack of transparency" (more: Góralczyk, 2017, p. 153-162).

Recognizing the problems within this cooperation, as well as the reluctance towards it expressed openly in the EU institutions and major capitals of EU Member States, starting with Berlin, the Chinese side at the $16+1$ summit in November 2016 in Riga, through the head of its delegation, Prime Minister Li Keqiang, came out with another, five-point cooperation proposal. It assumed stimulation of trade, acceleration of construction of transport connections (both infrastructure and logistics), construction of Chinese industrial and technological parks in 16 countries (one of them was already established outside it, in Minsk, Belarus), revival of financial cooperation (the Hungarian National Bank is involved in research projects on the internationalization of the yuan) and increasing the tourism and personal exchange (Oehler-Sincai, 2018, p. 8).

This partial change in priorities has changed little so far, China is apparently still not satisfied with this cooperation. Although the initial assumptions were different and focused on the economy and trade, the level of political cooperation still precedes the level of economic exchange. The only measurable achievement so far in the framework of the $16+1$ initiative is the establishment of its Secretariat based in Beijing ${ }^{8}$ and annual summits, the last of which took place in Sofia in July 2018. ${ }^{9}$ The Chinese side, however, seems to be increasingly moving towards the concept presented by President Xi Jinping to the participants of the Suzhou Summit (November 2015) to "fully integrate" the 16+1 concept with the BRI (Joić, 2017, p. 2). There are also ideas that the $16+1$ summits

8 A separate Secretariat, coordinated by Poland, was also established to coordinate logistic cooperation.

9 They are supplemented by a whole network of other meetings and conventions: four times a year meetings of 16 ambassadors in Beijing, organized once every six months (once in Beijing, once in the state organizing the annual summit) meetings of the National Project Coordinators, complemented by meetings of think tanks and experts. 
should not be - like thus far - annual, but once every two years, which for many observers is a proof that the project, however, did not gain much support.

Nonetheless, before the last summit in Bulgaria, there has been much publicity about an invite for Germany as well. This idea has been pushed for a while by Chinese specialists dealing with Germany, who explicitly treat the entire CEE region as a German sphere of influence in the political and economic dimension. Therefore, as they suggest, the inclusion of Germany in the 16+1 framework would be the best way to remove their expressive suspicions about China's real motives for involvement in this area (Zou, 2018, p. 8, 9).

There is another important element proving the new dynamics of events around this idea, a new geostrategic factor that is the unconventional behavior of the administration and President Donald Trump himself, in relations with China and the Asia-Pacific region as well as transatlantic within NATO and bilateral relations between the USA and the EU. In this context, the Chinese side is looking for new solutions, as evidenced by the visit of the head of the Chinese delegation, Prime Minister Li Keqiang, immediately after the Sofia Summit went to Berlin, where an unprecedented decision was made for the German conglomerate BASF to build its own investment worth 10 billion dollars in the south of China, without the participation of Chinese capital, which is a completely new solution and not used thus far in the PRC. 10

Another valuable achievement of cooperation within the framework of $16+1$ is the establishment in April 2017 in Budapest of the China - CEE Institute by the Chinese Academy of Social Science (CASS) in Beijing, the most serious Chinese think tank working for the authorities, the first of its kind research institute outside China. It was headed by the heads of the CASS European Institute, who had already demonstrated the largest range of research on $16+1$ and BRI (along with a valuable publishing series) ${ }^{11}$ and they are the most valuable research facility in this respect alongside the special China Silk Road Institute instituted in Beijing before the first BRI summit (henceforth to be organized every two years). The Institute in Budapest has already published two valuable series of working papers on cooperation in the framework of $16+1$ and BRI initiatives. Further events and publications are planned, including books. ${ }^{12}$

10 https:/cen.acs.org/business/petrochemicals/BASF-considering-10-billion-investment/96/ web/2018/07 (16.07.2018). See also: https://thediplomat.com/2018/07/whats-next-for-the-chinacee-161-platform/

11 Three most valuable works thus far are: Zuokui, 2017; Ping and Zuokui, 2017; Xin, 2017.

12 In the first tranche, published in November 2017, it was more than a dozen studies, in the second, published in June 2018, more than twenty. They are available at www.china-cee.eu and are an important material also used in this study. 
The state of research available so far shows that:

- The countries of the CEE region, like the countries of the whole EU, are quite divided in relation to Chinese initiatives. The most positive are Hungary, the Czech Republic and Romania, and - most recently - the area of the Western Balkans, i.e. the post-Yugoslavian countries, with the leading role in this respect of Serbia. On the other hand, Poland, the Baltic States, Albania and Slovakia are more restrained.

- The investment cooperation in the center in Chinese proposals and interests does not bring the expected results so far, and Chinese investments aimed at Europe are placed primarily in Germany, Great Britain, France, and Italy. Recently, from 2017, there is also a new dynamic in this regard in the Western Balkans (Smederevo metallurgical plants, Kostolac hotspots and the country's first wind farm in Serbia, Rimac electric car factory and renovation of the Krapinske Toplice spa and a bridge on the Pelješac peninsula in Croatia, the "five ports" initiative covering the Italian ports of Trieste, Venice, Ravenna, Slovenian Koper and Croatian Rijeka). At the same time, all research and data show that Serbia is the first partner of China in the Western Balkans, the second country in the framework of the 16, alongside Hungary, with a clear political will to develop this cooperation, which is even more visible in contrast with the region's, including Poland, perceptible disappointment with the state of existing cooperation.

- However, as far as the Chinese investments in the CEE region are concerned, the V4 countries still play a leading role, including the Czech Republic (34\% of the total 16, where Chinese companies have taken over the local airlines, the Sparta Praha sports club, two luxurious hotels in the center of Prague, and the acquisition of a large brewery is being negotiated), Hungary (19\%, mainly taking over the chemical conglomerate Borsodchem by Wanhua) and Poland (9\%) (Yue, 2018, p.12,13).

- Only Hungary in the region has a clear strategy from 2011 towards China and its partners in the East, called keleti nyitás (opening up to the East), which, however, did not bring the expected results so far, although it politically brought the two countries closer together. Available studies also show that Hungary is at the top of the list of 16 countries where the most events and joint ventures with China are organized.

- The current course of cooperation in the framework of $16+1$ proves that it runs almost exclusively on the basis of bilateral agreements of 16 countries with China and did not bring any new quality in regional cooperation (the project of a faster rail linking Budapest with Belgrade, the "five ports" project only on paper, etc.). Moreover, in many countries of the 16, controversies 
are triggered by Chinese financing conditions for the proposed investments, including a significant share of their representatives and companies on construction sites. The same is happening on the EU side, which even came out recently with a screening proposal, that is a close monitoring of China's contracts and investments in its area.

\subsection{Perception of BRI in Poland}

Although born and announced in Poland, neither the concept of $16+1$ nor following it no longer regional but global in its dimension BRI became the focus of Polish foreign policy (Stanzel, Kratz, Szczudlik and Pavlićević, 2016). This is a clear shortcoming, as in the opinion of the author of this study, for the first time in long Chinese history (not counting a brief episode in autumn 1956, when the authorities in Beijing were on the side of the then national leader, seemingly opposing Moscow, Władysław Gomułka) that it is in the interest of China to develop cooperation with Poland. The main reason standing behind this calculation have nothing to do with the feelings, but hard interests: Poland is located on the main land axis of the Silk Road, leading from central China through Xinjiang, Kazakhstan, Russia and Belarus, to Western Europe (Amsterdam, Rotterdam and Hamburg).

Poland has an inalienable asset in relations with the China now gaining global momentum in the form of its location on the map. What has been the Polish real curse for centuries, the location between Russia and Germany, from China's calculated view is the best possible geostrategic asset. It would be worth to use it properly, but - so far - both sides have managed to achieve successes only in the political sphere, and much less in the economic sense, although by assumption it should be the other way around.

The problem of democratic Poland in its relations with China consisted in the fact that for a long time it was overshadowed by a single date: June 4, 1989, when the serious crisis on Tiananmen Square and around took place and was violently resolved in China, while in Poland on the same day instead of a crackdown the first, limited, partly democratic elections were held. Already in September that year it brought about the first democratic government in the countries of the former Eastern bloc, that is the cabinet of Prime Minister Tadeusz Mazowiecki. Later this symbolic and significant date became a kind of "cornerstone” of bilateral relations, strongly - ideologically - burdening them, despite the fact that China approaches cooperation with other countries pragmatically, not ideologically (Góralczyk, 2009, p. 428). Over the next two decades, at least until the great crisis on global (read: the Western) markets, 
the approach of democratic Poland to authoritarian China was saturated with a kind of messianism or a sense of superiority (a new democracy over autocratic - outdated and outgrown - „real socialism”).

The situation changed only at the turn of the first and second decade of the 21st century, partly due to the 2008 crisis, and perhaps even to a greater extent due to the slow awareness of the rapidly growing role of the PRC as an economic and trading giant throughout the West. The political breakthrough in bilateral relations was the visit of President Bronisław Komorowski in China at the end of 2011, when agreements were signed, and mutual relations were brought to the strategic partnership level. Afterwards, during the visit of President Xi Jinping in Poland in June 2016, bilateral relations were raised to the highest possible level: a comprehensive strategic partnership (Xinhua, 2016). The political dialogue at the highest level was supported by: the visit of President Andrzej Duda at the $16+1$ summit in Suzhou (although organized at the level of prime ministers, the Polish side, using the time of changing its own administration, sent the president there, to which the Chinese responded - with an ad hoc organization of the official visit of the Polish president, proving the importance attached to mutual relations) and participation of Polish Prime Minister Beata Szydło at the first BRI summit in Beijing in May 2017.

Unfortunately, the agreements accompanying these visits (moreover, this was not always the case), including nearly 40 signed during the visit of the Chinese head of state in the Republic of Poland, either were not implemented or were significantly slowed down. The decision of the head of the Polish Ministry of National Defense has become a symbol, to not give the Chinese party permission to purchase a plot of land belonging to the Military Property Agency, on which the Chinese side intended to build a - crucial in their plans - communication center on the land Silk Road.

The solution, which was applied as a result of this Polish decision, i.e. signing agreements at the local government level and transferring Chinese rail transport from Łódź to nearby Kutno, proves, firstly, the effectiveness and determination of the Chinese side and, secondly, its great pragmatism. Poland is in Chinese plans an important link in the framework of $16+1$ as well as the BRI and it is to remain as such. As a result, we are dealing with many Chinese enterprises in the Republic of Poland, acting most often of a local level, as a result of agreements with the self-government authorities.

First, the issue of rail connections needs to be addressed. For in this respect Poland is playing not just a central but even a pioneer role in the region. It is due to the fact that even before the announcement of the $16+1$ and BRI initiatives, the Hatrans company located in Lódź came up with the proposal 
to use railway connections for the development of trade relations with China. The first trains from Chengdu in Sichuan province arrived after a two-week trip to Lódź on January 2, 2013. Connections in both directions were initiated in May of the same year, complementing other high-profile and significant connections with China on the Chongqing - Duisburg line, opened in 2011. Regular communication of freight trains on this route began in 2015. At the initial stage, the goods went almost exclusively in one direction - from China to Poland (Czerep, 2017). ${ }^{13}$ It was only after 2015 that the situation began to change a little, and also freight trains going to China, both from Lódź and Kutno, began to be loaded, mainly with agricultural goods, such as fruit, mainly apples or processed vegetables, and over time also chemical and industrial goods. It is estimated that at the end of 2017, approx. 25 percent of all goods arriving by rail to the EU came to Kódź and Kutno, while the dynamics of rail traffic between China and the EU has increased hundredfold over the past decade.

Even before the inauguration of railway connections, which is also difficult to consider as a real coincidence, already in 2009, the Chinese company Covec won a tender for the construction of a motorway section connecting Łódź and Warsaw, which was the first experiment of this type performed by a Chinese company in the EU. This venture, however, did not end in success. Covec was first forced to withdraw from the Polish market and then to pay compensation. It turned out that different business mentalities collided with each other: the Chinese trusted high-level political agreements and assurances, thus acknowledging that they had guanxi, that is the connections with appropriate persons and high-level decision makers, did not make proper market analysis (they entered without a feasibility study), and then collided with the EU legal requirements and slow inflow of money, which triggered the rebellion of Polish Covec subcontractors. In other words, the Chinese mentality based on personal relations and ties has clashed with the EU bureaucratic and institutional order: for them the people and positions count, for us (read: in the EU) institutions, rules, and legal regulations.

Covec's failure, however, did not discourage China. On the contrary, it has even increased its presence in Poland and the region, treating the case of this company as an accident at work and, at the same time, valuable experience on a difficult and demanding EU market.

13 Broader and more in depth on the subject: Jakóbowski, Popławski and Kaczmarski, 2018, p. 1 and 12. 


\section{Benefits and Risks Associated with BRI}

\subsection{Potential Benefits}

The second area, next to rail and prospects for using high-speed Chinese railways for connections in the region (Budapest - Belgrade), are the first contracts for Chinese investments in the energy sector in the CEE region. The largest and most advanced among them is Cernavoda II power plant in Romania, whose contract is worth 7 billion euros and is to be finalized as early as 2019. Other signed agreements concern nuclear power plants Temelin - Dukovany in the Czech Republic (around 15 billion euros but they are to be launched in the third decade of this century) and Belene in Bulgaria. In this context, what also draws attention are the first Chinese projects and investments in Poland, carried out at the local level, such as the construction of electric traction in the vicinity of Słupsk, Szczecin, Chełm, and Lublin by the Chinese conglomerates China State Grid (the first two) and Sinohydro (the other two).

Two previous investments, or rather acquisitions - of the StalowaWola steelworks by the Liugong company and the Bearing Factory in Krasnik by TriGong, were joined in recent years by such investments as takeover by China Everbright Intl. of Novago company in Mlawa specializing in waste disposal, or Hongbo near Opole (led lighting), Nuctech in Kobyłka (equipment at airports), as well as the construction of the TCL TV assembly plant near Żyrardów, bicycle storage facility in Koszalin (Athletic Group) or candle production near Tarnow (Dalian Talent) (Sarek, 2017, p. 70-73).

As it can be seen, and what can be proved, China's economic and investment presence in Poland is constantly growing, but it is rather selective and single-site. Neither is it common or forced from above. Most agreements, despite excellent political relations at the highest level, are signed at the local or local government level. As such, it is difficult to regard them as carrying a Chinese development model to Poland or even its solutions in industrial policy or management. They should still be considered as limited undertakings. There is a lack of a serious investment (in both directions) in our bilateral relations that could be considered symbolic. On the other hand, the discussion on the involvement of Chinese capital in the construction of the Central Airport (Communication Hub) located between Warsaw and Łódź, should be considered more as media speculation than real agreements, as for now.

However, the most important, inalienable asset in Poland's bilateral relations with China is the fact that the Chinese side has come out with two bold projects, 
first cooperation with the countries of our region in the formula $16+1$ and then as part of the BRI vision. Although it is not known what the fate of these projects will be, and whether - from China's will - there will be a merger between them, it seems that China's interest in Europe and the EU, including Poland, will remain permanent and may even increase due to recent American isolationist visions and looming trade war.

This last factor, due to the specificity of Polish relations and the alliance with the US, will probably not facilitate relations with the new player in our region, which China became, but certainly imposes more creative and strategic thinking on the part of Warsaw as well.

The Chinese side is constantly emphasizing that the BRI has the most open character, practically anyone who wants to, can join the project. On the other hand, Poland not only can but should do it, - for three basic reasons: 1 . Location; 2. Chinese interests related to our country stemming from point $1 ; 3$. The largest potential in the CEE region. However, the degree of this commitment should be constantly measured and dosed carefully, because we are dealing with the asymmetry of potentials and power. China is a new global player with its interests, and Poland is - and should be - located in the West, both in terms of security (NATO) and in the economic sphere (EU, Germany), although in the latter the BRI is proving how important a player China became in practically all areas of the world, including the region $(16+1)$. It is time to draw proper conclusions from that also in Warsaw.

\subsection{Potential Risks}

The basic problem of Poland and other CEE countries in relations with China is that they are asymmetrical relationships. We are dealing with a partner growing into a new superpower, the second economy in the world (the first in the sense of Purchasing Power Parity) and the state that after 2012 is openly proclaiming that it is going to be number one in the world, not only in the economic or commercial dimension. Thus, relations with this partner are of a geostrategic character and require deep strategic reflection.

Poland is and will remain a member of Western alliance (NATO) and, like the countries of the region, it is economically dependent on the EU markets, Germany above all. Thus, closer relations with China may arouse some suspicions of our allies, starting with the US, as well as our trading partners, starting with Germany. These factors must be considered in all agreements and contacts with the Middle Kingdom. This is what the requirements of strategy and geostrategy dictate. 
Chinese initiatives 16+1, and then the BRI, caused that, whether Poland wanted to or not, both our country and our region entered the great game. It is already visible and obvious that the Chinese have not only appeared on our markets, but also have their interests and fields of influence here. Meanwhile, for example, infrastructure projects strongly enforced by China in many cases are in contradiction with the TEST (Tran-European Transport Network) being pushed by the EU, is just another issue which proves the controversy regarding possible agreements with the Chinese side. In the case of Poland, this requires reflection and consideration of whether we are in favor of the EU Baltic and Adriatic corridor project and whether we want to seek synergy between the project promoted by the Polish authorities, especially the president, to build the Three Seas strategy and similar Chinese proposals aimed at connecting the maritime and the land Silk Road. These initiatives can be treated as separate, or we can try to combine them: the choice belongs to the authorities in Warsaw.

In turn, in the purely economic dimension, the biggest problem is the chronic trade deficit of our region's countries against China, and the $16+1$ and BRI initiatives have changed little in this respect. According to Chinese data, in 2010-2016, Chinese exports to the CEE region increased by 22.74 percentage, from 53.09 to 65.17 billion dollars, while import increased by $41 \%$ at that time, but it closes with much smaller sums - from 6.89 to 9.72 billion dollars. In addition, these turnovers in recent years account for only approx. 10 percent of entire EU trade turnout with China, while the negative trade balance increased from 46.2 to 55.45 billion dollars during this time (Jing and Xiaojing, 2018, p. 2, 3). The matter is so serious that it was placed in the final document after the last 16+1 summit in Sofia (Szczudlik-Tatar, 2018).

This deficit is also a major problem in Poland's relations with China. In the period 2009-2017 it almost doubled, from 9 to $14.5 \mathrm{ml}$ dollars, and thus overshadowed the unquestionable success of Poland, which was the highest ever export of Polish goods to China in 2017 in the amount of USD 3.35 billion, increasing more than three times in relation to the level before the launch of the 16+1 formula. According to data provided by the Central Customs Office of the PRC, which do not fully coincide with the Polish Central Statistical Office, the bilateral trade increased in 2012-2017 from 12.3 to - for the first time in history - over 20 billion dollars according to Chinese data (17.85 according to the Polish Central Statistical Office). ${ }^{14}$

14 https://www.bankier.pl/wiadomosc/Eksport-z-Polski-do-Chin-najwyzszy-w-historii-7568470.html (16.07.2018). 
The ambiguity in the statistics on trade with China is that a significant part of it goes through Hong Kong and tax havens like the Cayman Islands or the Virgin Islands. Thus, it is more difficult to obtain homogeneous and more precise data. Whereas the basic problem of the serious trade deficit naturally puts a great shadow on our entire bilateral relationship. According to the calculations of one Chinese author, the cumulated Polish deficit in trade with the PRC in the period 2008-16 amounted to USD 154.4 billion (Yue, 2018, p. 9).

This state of affairs is worrying because it must worry. All the more so because in the Chinese commodity offer there are more and more highly processed goods including high technologies, while raw materials or unprocessed goods prevail in ours, only recently supplemented with chemicals or pharmaceutical products. This way, the country which the EU (together with the US) is denying the Market Economy Status (MES) and is designed as a "developing country" exports higher quality goods to an area formally belonging to the EU, thus meaning one of the most developed organisms in the world.

This is not the only paradox proving that the approach to China should be reevaluated as soon as possible. Meanwhile, only Hungary has developed a strategy for cooperation with China and a political will to continue it. Meanwhile only Slovakia - a country with a somewhat poorly developed scale of cooperation with China - has developed a special Action Plan for the period 2017-2020, complemented by the government's concept for development of economic relations with PRC (Kironská and Turcsányi, 2017, p. 9). Whereas such documents would certainly be useful in all CEE countries.

In Poland, regular analyses of China at the central level are carried out, at a comprehensive, but so far insufficient level, by only two institutions: the Polish Institute of International Affairs (PISM) and the Center for Eastern Studies (OSW). The first is focused on the studies of the entire foreign policy of the state, in which the approach to China or emerging markets plays only a marginal role (only two analysts dealing exclusively with China), and the other is much more concentrated on post-Soviet areas than the East Asia region. Meanwhile, the latter - along with China and Taiwan, also both Koreas and Japan - is playing an increasingly important role on the international arena, not only in the economic and commercial dimension, but also strategically. It would be worth drawing proper conclusions from this by setting up a special team or even an analytical institute dealing exclusively with this area. Due to the new and constantly growing role of East Asia it should be created as soon as possible as a fulfillment of the well-understood interests of the state. 


\section{Conclusions}

The so-called fifth generation of PRC leaders led by Xi Jinping, in power since the end of 2012, broke with the previous policy of modesty, low profile and (re) building its own power quietly, without drawing attention of the outside world, as postulated in the political testament of a visionary of first market-oriented reforms (1978), and then of China's inclusion in globalization (1992), Deng Xiaoping. The new team came out with very bold projects both on the domestic ("two centennial goals") and international stage, in the form of OBOR - BRI. From now on, relations with China should be treated as with a newly emerging superpower, having an impact on the balance of power in the world, through its weight and rank restoring the new multipolar world order, with China having more and more to say in many areas, also in the sphere of development models, what this volume is all about, and to what - as this analysis demonstrates - the Polish side apparently does not give proper attention.

The previous $16+1$ vision of 2012 , preceding the BRI, is a good platform for cooperation between China and the region, although from the beginning it raised suspicions or controversy over China's „divide and rule” principles, be it in the US or EU institutions and major capitals of EU states, starting with Berlin, as - as shown by available statistics and data - the entire CEE region is economically and commercially dependent on Germany. This factor must be constantly included in Polish calculations, when considering any development of relations with China, a desirable partner, as it has its own interests here, and in addition rich capital resources and own projects and proposals.

It is the external factor that brought about a new dynamics, or rather turbulence, into relations both with China and the EU by the new American administration of Donald Trump, in power from January 2017. Not only some countries of the 16 (like Estonia, Lithuania or Albania) began to hesitate about their further participation in this format, but they also began to think about their further functioning in this formula. At the same time the originators themselves, that is the Chinese side, as evidenced by - never officially confirmed, but also not negated through Beijing - concepts of the organization of the 16+1 summits not once a year but once every two years (the next is announced in Croatia, but without a date), and including „oversensitive” Germany into this formula. More and more signals from China also indicate that the $16+1$ formula will become an integral part of the BRI. 
This is primarily in response to the American concepts of unilateralism, protectionism, and even commercial war implemented by the Donald Trump administration, that the Chinese side is increasingly pushing its own concepts, that is the support for globalization and the principles of free trade and rules in force at the WTO. Moreover, the Chinese leaders oppose the project America First, by promoting their concept of community of shared destiny, and therefore a community of interests based on globalization, where in addition - according to Beijing - the principle of mutual benefits (win-win) is supposed to dominate, which, however, not all Chinese partners take at face value.

This approach of China and its growing potential, including investment potential (from 2014, outgoing Chinese investments are larger than those that come to it) is the reason for which literally every country in the world should carry out some examination of conscience in relations with this new colossus. This is also true of Poland, the most important country in the CEE region, in addition located on the main land route of the Silk Road drawn by China. Besides the initiated by the Polish side railway transports between the two countries, these are two inalienable advantages of our country in relations with China, which in addition, is guided by its own interests, and not only wants to come to Poland, but is actually coming - as an investor and a new player.

Unfortunately, as the present analysis proves, a very good network of relations at the highest political level, including visits of presidents of both countries to each other, have not been transformed into real economic success so far, and Poland is still struggling with a chronic deficit in trade with this partner, while new agreements and contracts are signed more at the local than at the national level. The current authorities in Poland, after the first visible admiration in relations with the new strongman, later apparently slowed cooperation with China, which should be understood foremost as a response to a completely new dynamics of relations in the US-EU-China triangle. Similarly, not without meaning to the course of bilateral Poland - China relations, unsurprisingly, are very close ties and cooperation between China and Russia, treated in Warsaw biggest antagonist of Poland.

However, this does not change the fact that the large-scale concept of BRI is and will be pushed through by Beijing, and Poland is considered in these calculations as an important partner. It would be worth to use our considerable advantages properly. What is needed, however, is the political will, as well as the wider expert base of decision-makers, able to develop - indispensable in the present circumstances - a strategy of relations with China. We have such potential in the personal sense. All that is needed is imagination and political will to use it. 


\section{References}

Allison, G. (2017). Destined for War. Can America and China Escape Thucidydes Trap? New York: Houghton Mifflin Harcourt.

b.d. (2017). "Chiński Dylemat" (Chinese Dilemma), Polski Przeglad Dyplomatyczny 3(70), July-September.

Bartosiak, J. (2016). Pacyfik i Eurazja. O wojnie (Pacific and Eurasia. On War). Warszawa: Wydawnictwo CSPA.

Czerep, J. (2017). Influence of the Łódź-Chengdu railway on the perception of $16+1$ in Poland. China - CEE Institute Working Paper, No. 5, Budapest, 15 November.

Deng, J. and Liu, X. (2018). Deepening the "16+1 cooperation" relationship to foster the new growth pole of Sino-EU Trade. China - CEE Institute Working Paper, No. 13, 22 June.

EEAS. (2016). EU - China 2020. Strategic Agenda for Cooperation. Acquired from: https:// eeas.europa.eu /sites/eeas/files/20131123.pdf.

Godemont, F. and Vasselier, A. (2017). China At the Gate. Anew Power Audit of EU - China Relations. ECFR, December. Acquired from: https://www.ecfr.eu/page/-/China_Power_ Audit.pdf.

Góralczyk, B. (2017 a). China's interest in Central and Eastern Europe: enter the dragon. European View, 16, June.

Góralczyk, B. (2017 b). Eastern-Asian development model: the growth-fostering state, In: J. Yifu Lin, A.Z. Nowak (eds.), New Structural Economics for Less Advanced Countries, Warsaw: Wydawnictwo Wydziału Zarządzania UW.

Góralczyk, B. (2018). Wielki Renesans. Chińska transformacja i jej konsekwencje (Great Renaissance. Chinese Transformatrion and its Consequences). Warszawa: Wydawnictwo Naukowe Dialog.

Góralczyk, B. (Ed.). (2009) Poland - China. Yesterday, Today, Tomorrow, Toruń: Wydawnictwo A. Marszałek.

https://cen.acs.org/business/petrochemicals/BASF-considering-10-billion-investment/96/ web/2018/07 (16.07.2018).

https://global.handelsblatt.com/politics/eu-ambassadors-beijing-china-silk-road-912258 (20.07.2018).

https:/www.bankier.pl/wiadomosc/Eksport-z-Polski-do-Chin-najwyzszy-w-historii-7568470. html (16.07.2018).

https://www.project-syndicate.org/bigpicture/trump-s-trade-war-expands (16.07.2018).

https://www.project-syndicate.org/bigpicture/trump-s-trade-war-expands (16.07.2018).

Huang Ping, Liu Zuokui (eds.), China - CEEC cooperation and the 'Belt and Road Initiative', Beijing: China Social Sciences Press.

Jakóbowski, J., Popławski, K. and Kaczmarski M. (2018). Kolejowy Jedwabny Szlak. Połączenia kolejowe UE - Chiny: uwarunkowania, aktorzy, interesy (Railway Silk Road: Railway connections the EU - China: conditions, actors, interests), Prace OSW, 72, Warszawa, February.

Jing, D. and Xiaojing, L. (2018). Deepening the " $16+1$ cooperation" relationship to foster the new growth pole of Sino-EU Trade. China - CEE Institute Working Paper, No. 13, 22 June.

Joić, S. (2017). How Serbia perceives „The Belt and the Road” Initiative and 16+1 Cooperation. China - CEE Institute Working Paper, No. 9. Budapest, 15 November. 
Kironská, K. and Turcsányi, R.Q. (2017). Slovak Policy towards China in the age of Belt and Road Initiative and 16+1 Format. China - CEE Institute Working Paper, No. 2. Budapest, 15 November.

Lin, Y. (2018). Economic 'highway' with three speed tracks and destinations between China and CEE.China - CEE Institute Working Paper, No. 14, Budapest, 22 June.

Maddison, A. (2007). Chinese Economic Performance in the Long Run (2nd edition).OECD, Paris: Development Centre Studies.

MERICS and Rhodium Group. (2017). Chinese Investment in Europe: record flows and growing imbalances. Joint report by MERICS and Rhodium Group. Berlin: MERICS - Mercator Institute for China Studies, January. Acquired from: https:/www.merics.org/en/paperson-china/chinese-investment-europe-record-flows-and-growing-imbalances (15.07.2018).

Oehler-Sincai, I.M. (2018). 16+1, a New Issue in China-EU Relations? China - CEE Institute Working Paper, No 1. Budapest, 22 June.

Pillsbury, M. (2016). The Hundred-year Marathon. China's strategy to replace America as the global superpower. New York: St. Martin's Griffin.

Sarek, Ł. (2017). Chiński dylemat polskiej polityki zagranicznej (Chinese Dilemma of Polish Foreiogn Policy), Polski Przeglad Dyplomatyczny „Chiński Dylemat”, 3 (70), July-September.

Stanzel, A., Kratz, A., Szczudlik, J. and Pavlićević, D. (2016).China's investment in influence: the future of 16+1 cooperation. ECFR, December.

Szczudlik-Tatar, J. (2018). Perspektywy format Europa Środkowa - Chiny po szczycie w Sofii (Perspectives of CEE - China Cooperation after the Sofia Summit), Biuletyn PISM, 91, 13 July.

Winter, T. (2016). One Belt, One Road, One Heritage: Cultural Diplomacy and the Silk Road. The Diplomat, 29 March.

Xi, J. (2014). The Governance of China. Mainland China: Foreign Languages Press.

Xi, J., President Xi Addresses the 2018 Boao Forum for Asia in Hainan, Boa., 11 April. Acquired from: https://www.uscnpm.org/blog/2018/04/11/transcript-president-xi-addresses2018-boao-forum-asia-hainan/ (15.07.2018).

Xin, Ch. (ed.). (2017). How Hungary Perceives Belt \& Road Initiative and China-CEEC Cooperation. Beijing: China Social Sciences Press.

Xinhua. (2016). China, Poland lift ties to comprehensive strategic partnership. Acquired from: http://www.xinhuanet.com/english/2016-06/21/c_135452132.htm (16.07.2018).

Xinhua. (2017). Xi Jinping's keynote speech at the World Economic Forum. Davos, 27 January. Acquired from: http://www.china.org.cn/node_7247529/ content_40569136.htm.

Yue, L. (2018). Economic 'highway' with three speed tracks and destinations between China and CEE.China - CEE Institute Working Paper, No. 14, Budapest, 22 June.

Zhang, X. (2016). Chinese Capitalism and the New Silk Roads. Aspen Quarterly, 4.

Zou, L. (2018). An Analysis of Germany's Suspicions about „16+1 Cooperation” and China's Possible Countermeasures - From the Perspective of European Integration. China - CEE Institute Working Paper, No. 5. Budapest 22 June.

Zuokui, L. (2017). Europe and the "Belt and Road" Initiative: Responses and risks. Beijing: Paths International Ltd./China Social Sciences Press/CASS. 